\title{
Structural alterations in peripheral arteries during experimental heart failure : opposing effects of vasoconstrictors and vasodilators
}

Citation for published version (APA):

Heeneman, S. (1997). Structural alterations in peripheral arteries during experimental heart failure : opposing effects of vasoconstrictors and vasodilators. [Doctoral Thesis, Maastricht University]. Universiteit Maastricht. https://doi.org/10.26481/dis.19970522sh

Document status and date:

Published: 01/01/1997

DOI:

10.26481/dis.19970522sh

Document Version:

Publisher's PDF, also known as Version of record

Please check the document version of this publication:

- A submitted manuscript is the version of the article upon submission and before peer-review. There can be important differences between the submitted version and the official published version of record.

People interested in the research are advised to contact the author for the final version of the publication, or visit the DOI to the publisher's website.

- The final author version and the galley proof are versions of the publication after peer review.

- The final published version features the final layout of the paper including the volume, issue and page numbers.

Link to publication

\footnotetext{
General rights rights.

- You may freely distribute the URL identifying the publication in the public portal. please follow below link for the End User Agreement:

www.umlib.nl/taverne-license

Take down policy

If you believe that this document breaches copyright please contact us at:

repository@maastrichtuniversity.nl

providing details and we will investigate your claim.
}

Copyright and moral rights for the publications made accessible in the public portal are retained by the authors and/or other copyright owners and it is a condition of accessing publications that users recognise and abide by the legal requirements associated with these

- Users may download and print one copy of any publication from the public portal for the purpose of private study or research.

- You may not further distribute the material or use it for any profit-making activity or commercial gain

If the publication is distributed under the terms of Article $25 \mathrm{fa}$ of the Dutch Copyright Act, indicated by the "Taverne" license above, 
Structural alterations in peripheral arteries during experimental heart failure

Opposing effects of vasoconstrictors and vasodilators 


\section{CIP-DATA KONINKLIJKE BIBLIOTHEEK, DEN HAAG}

Heeneman "Sylvia

Structural alterations in peripheral arteries during experimental heart failure Opposing effects of vasoconstrictors and vasodilators / Sylvia Heeneman Ponsen \& Looijen B.V. (drukwerk)

Thesis Maastricht. - with ref. - with summary in Dutch ISBN 90-9010453-4

Subject headings: heart failure, peripheral vasculature, neuro-hormonal activation 


\section{Structural alterations in peripheral arteries during experimental heart failure}

Opposing effects of vasoconstrictors and vasodilators

\section{Proefschrift}

ter verkrijging van de graad van doctor, aan de Universiteit Maastricht, op gezag van de Rector Magnificus, Prof. Mr. M.J. Cohen, volgens het besluit van het College van Decanen, in het openbaar te verdedigen

op donderdag 22 mei 1997 om 14.00 uur

door

Sylvia Heeneman

geboren te 's-Gravenhage in 1968 


\section{Promotores}

Prof. Dr. J.W. Arends

Prof. Dr. J.F.M. Smits

\section{Co-promotor}

Dr. M.J.A.P. Daemen

\section{Beoordelingscommissie}

Prof. Dr. H.J.J. Wellens, voorzitter

Dr. C. Aalkjaer, University of Aarhus, Denmark

Prof. Dr. C.A.M.A.V. Bruggeman

Prot. Dr. P.W. de Leeuw

Prof. Dr. R.S. Reneman

The studies presented and the publication of this thesis were financially supported by the Netherlands Organization for Scientific Research (N.W.O.) (grant 902-18-291).

Financial support by the Netherlands Heart Foundation for the publication of this thesis is gratefully acknowledged.

For financial support for the publication of this thesis, I also thank:

- De Dr. Ir. J.H.J. van der Laar Stichting

- Stichting Klinische Pathologie Zuid-Limburg 
The most exciting phrase ever heard in science, is not 'eureka' (I found it), but 'that's funny'...

- Isaac Asimov - 
Contents

$\begin{array}{llr}\text { Chapter } 1 & \text { Introduction }\end{array}$

General 10

Peripheral vascular alterations during heart failure $\quad 10$

Possible mechanisms for peripheral alterations $\quad 12$

Hypothesis 30

This thesis 31

Chapter $2 \quad$ Peripheral vascular alterations during experimental heart failure. Do they exist?

Chapter 3 Effects of angiotensin II infusions on cardiac function and peripheral vascular structure during compensated heart failure in the rat.

Chapter $4 \quad$ Opposing effects of angiotensin type 1 and type 2 receptor blockade on blood pressure and peripheral vascular structure in rats with a myocardial infarction.

Chapter $5 \quad$ Vascular structure and basal release of nitric oxide during experimental heart failure in the rat.

Chapter 6

General discussion

129

Summary

Samenvatting

Curriculum Vitae

150

Dankwoord 


$\begin{array}{ll}\text { AA } & \text { Abdominal aorta } \\ \text { ACE } & \text { Angiotensin converting enzyme } \\ \text { ANG I } & \text { Angiotensin I } \\ \text { ANG II } & \text { Angiotensin II } \\ \text { ANP } & \text { Atrial natriuretic peptide } \\ \text { BNP } & \text { Brain natriuretic peptide } \\ \text { CA } & \text { Carotid aorta } \\ \text { CNP } & \text { C-type natriuretic peptide } \\ \text { AT1 receptor } & \text { Angiotensin II Type-1 receptor } \\ \text { AT2 receptor } & \text { Angiotensin II Type-2 receptor } \\ \text { CSA } & \text { Cross-sectional area } \\ \text { CGMP } & \text { cyclic } 3^{\prime}, 5^{\prime} \text {-guanosine monophosphate } \\ \text { ET } & \text { Endothelin } \\ \text { GFR } & \text { Glomerular filtration rate } \\ \text { IA } & \text { lliac artery } \\ \text { LAD } & \text { Left anterior descending artery } \\ \text { L-NAME } & \text { N'-nitro-l-arginine methyl ester } \\ \text { MAP } & \text { Mean arterial pressure } \\ \text { MI } & \text { Myocardial infarction } \\ \text { mRNA } & \text { messenger RNA } \\ \text { mRA } & \text { Mesenteric resistance arteries } \\ \text { NO } & \text { Nitric Oxide } \\ \text { ENOS } & \text { endothelial NO synthase } \\ \text { iNOS } & \text { inducible NO synthase } \\ \text { nNOS } & \text { neuronal NO synthase } \\ \text { NS } & \text { not significant } \\ \text { PRA } & \text { Pulmonary resistance arteries } \\ \text { RA } & \text { Renal artery } \\ \text { RAS } & \text { Renin Angiotensin System } \\ \text { SMA } & \text { superior Mesenteric artery } \\ \text { TA } & \text { Thoracic aorta } \\ & \end{array}$


Chapter

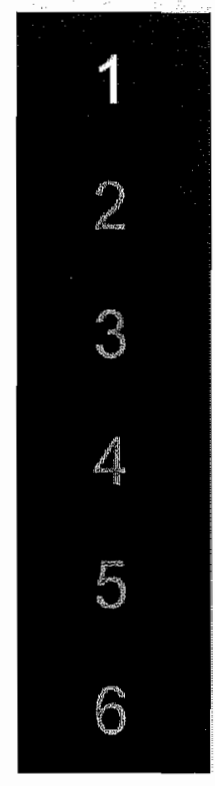

Introduction 


\section{General}

The clinical syndrome of heart failure reflects the inability of the heart to pump sufficient amounts of blood to meet the metabolic needs of the body at normal filling pressures (1). The initial event can occur in the form of coronary artery disease, hypertension, valve dysfunction or diabetes mellitus. The syndrome is characterized by circulatory congestion, edema and exercise intolerance $(2,3)$. Despite the relative success of new therapeutic strategies, as demonstrated for the angiotensin-converting enzyme (ACE) inhibitors in the CONSENSUS, SOLVD and SAVE trials $(4,5)$, death rates and hospital admissions continue to increase, both in the Netherlands and the United States. In the Netherlands, the annual number of hospital admissions because of heart failure increased by $69 \%$ from 14441 in 1980 to 24368 in 1992 (6). Cardiovascular disease remains the leading cause of death in the United States and heart failure afflicts $1 \%$ of all men and women under the age of 50 and more than $10 \%$ of those over the age of 80 years (6-9).

The loss of cardiac function induces a series of compensatory mechanisms to maintain blood pressure and the perfusion of vital organs. These mechanisms include the development of cardiac hypertrophy, ventricular dilatation, activation of neurohormonal systems and peripheral vascular alterations. Although activation of these compensatory mechanisms may be beneficial in the initial stage of cardiac dysfunction, prolonged and/or abnormal activation may result in a vicious circle, with further deterioration of cardiac function. The final result is heart failure (1).

In the past, much research has been focussed on the changes in the heart muscle itself, but in recent years it has become clear that other factors are also important in the development of heart failure. This thesis concentrates on changes in peripheral vascular structure.

\section{Peripheral vascular alterations during heart failure}

\section{Aortic compliance}

Afterload is an important determinant of cardiac output. Afterload consist of a steady resistance component (determined by the resistance arteries) and a pulsatile component (determined by the elastic properties of the large conduit arteries) (10). Aortic compliance is a contributing factor to aortic impedance. It depends on the composition and geometry of the aorta and is a measure of distensibility. The dependence of left ventricular performance on aortic impedance has been shown in a dog model in which the intrathoracic aorta was bypassed by a stiff plastic tube (11). This resulted in an augmented cardiac dysfunction during acute coronary artery occlusion. Indeed, a positive linear relationship between the 
ejection fraction of the left ventricle and systemic arterial compliance suggests that arterial compliance is an important determinant of left ventricular afterload (12).

Aortic compliance is decreased during ventricular failure in animal models of heart failure $(13,14)$ and human heart failure $(15-18)$. It is unclear whether this vascular response is an early change or a late manifestation of the disease. Eaton et al. studied the aortic impedance spectrum $48 \mathrm{~h}$ after ventricular pacing (dog) and suggested that the reduced conduit vessel compliance may contribute to the progression of abnormal myocardial energetics and thus systolic dysfunction. Interestingly, this study also showed that changes in compliance may precede alterations in the peripheral vascular resistance (13). Although the impairment of arterial compliance is more marked in severe congestive heart failure, it is also manifest in mild heart failure (19). However, there are also studies which show no changes in aortic impedance during theart failure (20-22). The reasons for these inconsistent observations is not clear; some of these studies used indirect techniques to measure aortic impedance, but even the results from studies using similar techniques are not comparable $(15,21,22)$. Some of the discrepancy may be explained by the extent of cardiac failure in the different patient groups or by the medication used.

\section{Peripheral vasoconstriction}

Next to the possible changes in the pulsatile component during heart failure, changes in the resistance component are well known to occur and were first described by Zelis et al. in 1969. This study showed that in patients with heart failure both rest and exercise arm blood flow were reduced due to an increase in vascular resistance (23). The same group also showed that the vasodilator responses to adrenergic blockade, ischemia and direct arterial vasodilators were decreased in patients with heart failure (24). Also, attenuated increases in cardiac output and stroke volume following exercise were found (25). All these observations are indicative for excessive peripheral vasoconstriction during heart failure, since vasoconstriction and a reduced capacity to vasodilation (24) may prevent the development of severe hypotension in situations of prominent vasodilation as seen during exercise (26).

\section{Endothelial dysfunction}

Recently, attention has been focussed on an impairment of endotheliumdependent vasodilation during heart failure. The vascular endothelium modulates smooth muscle relaxation via the release of nitric oxide (NO) (27). The constitutive basal release of NO from the endothelium has been shown to contribute to the regulation of basal vascular tone (reviewed in references 28 and 29). Next to this basal release, endothelial NO synthesis can be induced by several agonists such as acetylcholine and bradykinin (reviewed in references 30 and 31). 
Ontkean et al. (32) showed impaired endothelium-dependent vasodilation in rats 10 weeks after induction of a myocardial infarction. Vasodilation in response to acetylcholine and adenosine diphosphate (both endothelium-dependent), but not to nitroglycerin (endothelium-independent) were decreased in isolated vessel rings of the thoracic aorta of rats with a myocardial infarction. These results suggest an impairment of acetylcholine mediated production of $\mathrm{NO}$ following myocardial infarction. Subsequently, other studies also showed impaired agonistmediated vasodilation in isolated aortic vessel rings of myocardial infarcted rats (33-35). In man, the endothelium dependent vasodilation is impaired in the coronary, skeletal muscle and skin circulation of patients with heart failure (3641). Interestingly, in an animal model for heart failure, this endothelial dysfunction has been shown to be present in the absence of hemodynamic compromise (34). In contrast, reports on changes in basal production of NO during human and experimental heart failure heart are conflicting. Human studies reported an intact $(41,42)$ or even enhanced basal release of NO $(43,44)$. Animal studies using isolated vascular rings, however, show decreased basal release of NO $(32,35)$. Thus, the status of the basal release of NO during heart failure is not clear yet.

\section{Possible mechanisms for peripheral alterations}

The mechanisms responsible for the above mentioned peripheral alterations are still incompletely understood. There is no doubt, however, that these mechanisms are complex and most likely form a network of events interrelating and influencing each other. In this outline, possible mechanisms will be discussed, like (a) neurohumoral activation and (b) structural vascular alterations. The neurohumoral mechanisms are divided in (a1) activation of the sympathetic nervous system, (a2) activation of the natriuretic peptides (a3) activation of endothelium derived vasoactive factors and (a4) activation of the renin-angiotensin system.

\section{Neurohormonal activation : The sympathetic nervous system (a1)}

\section{Introduction}

Evidence for sympathetic activation during left ventricular dysfunction comes from both clinical and experimental studies. First, plasma concentrations of norepinephrine are increased in patients with heart failure (45-48). Kinetic studies using tritiated norepinephrine have shown that these elevated norepinephrine levels result from an increased release and spillover, in combination with a decreased clearance (46). The increase in plasma norepinephrine reflects increased sympathetic activity. Also, direct microneurographic recordings of peroneal nerve activity have demonstrated increased sympathetic activity to skeletal muscle in patients with heart failure (49). Furthermore, studies in patients with severe untreated heart failure also show high plasma concentrations of 
norepinephrine, indicating that these high plasma concentrations are unrelated to drug therapy (50).

Elevated plasma concentrations of norepinephrine and epinephrine are correlated with poor prognosis $(51,52)$, and Cohn et al. reported that plasma norepinephrine was an independent predictor of mortality in heart failure (53). Moreover, a subgroup analysis of the results of the CONSENSUS trial showed that the ACE-inhibitor enalapril was effective in prolonging life expectancy, especially for patients with increased plasma concentrations of norepinephrine (52).

Also, a variety of physiological and pharmacological forms of stress has been used to test the integrity of adrenergic reflex control during heart failure. Upright orthostatic tilt normally leads to a rise in plasma norepinephrine and plasma renin. The receptors responsible are probably the low-pressure mechanoceptors, which are unloaded by the fall in central venous pressure during the tilt. In patients with heart failure, the response to tilt is significantly attenuated. Plasma norepinephrine concentrations do not rise and the normal decrease in forearm bloodflow is not seen (54-56). Francis et al. showed that, although plasma norepinephrine concentrations were higher in patients with heart failure, compared to normal controls, patients were unable to increase plasma norepinephrine levels during comparable percentages of peak exercise $\mathrm{O}_{2}$ consumption, indicating blunting of sympathetic drive (57). Also, other stimuli of the activity of the sympathetic nervous system, such as the cold pressor test (58) and electrical stimulation $(59,60)$ do not result in the expected sympathetic peripheral vasoconstriction.

\section{The arterial baroreflex during heart failure}

It is still unclear what causes the overactivity of the sympathetic nervous system during heart failure. One mechanism that has been proposed is a depression of the baroreflex $(61,62)$. Normally, cardiopulmonary baroreceptors, located in the heart and arterial baroreceptors, located in the aortic arch, carotid sinuses and pulmonary vasculature, respond to stretch during increased blood pressure by initiating reflexes that promote parasympathetic stimulation and restrain sympathetic efferent activity (63). Signals from the arterial baroreceptors inhibit the vasoconstrictor center and excite the vagal center. The results are a general vasodilation in the peripheral vascular bed and a decreased heart rate. The arterial baroreflex can have major effects on sympathetic and vagal outflow (64). As early as 1972 , Higgins et al. showed a depressed baroreflex in a dog model of heart failure. Before the induction of heart failure, carotid occlusion resulted in an increase in arterial pressure, heart rate and mesenteric resistance. A clear depression of this response was seen in the heart failure state (65). Other studies reported a similar depressed baroreflex function in patients with heart failure (58, $63,66,67)$. Blunted baroreceptor responses to high cardiac filling pressures or depressed cardiac function reduce afferent signals that normally inhibit 
sympathetic efferent activity, vasopressin release and renin secretion. As a result, neurohormonal activity will increase (62). Creager et al. showed that patients with heart failure have a comprised ability to increase their blood pressure during arterial baroreceptor unloading. They do, however remain able to reduce blood pressure during baroreceptor stimulation. Thus, reduced inhibitory signals from the arterial baroreflexes may contribute to the increased sympathetic activity during heart failure (63). However, not all studies show a decrease in baroreflex activity. Meyrelles et al. demonstrated preserved short-term baroreflex control of heart rate and even exaggerated baroreflex control one month after the induction of a myocardial infarction in rats (68). Schwartz et al. studied the evolution of baroreflex sensitivity in patients during the first year after myocardial infarction. Although the baroreflex sensitivity was decreased 3 months after infarction in a subgroup of patients, it returned to normal 13 months after the infarction (69).

Although most studies show that sympathetic tone and arterial baroreflex sensitivity are altered during heart failure, there have been no studies showing a cause-and-effect relationship. Arguments in favour of such a relationship are observations that baroreflex abnormalities constitute an early event after induction of heart failure in dogs (70) and that discontinuation of pacing in dogs or cardiac transplantation in humans restores the baroreflex control (66, 70-72). However, there are also studies in canine heart failure, induced by an aorta-caval fistula, that show persistent abnormalities of baroreflex control after closing the fistula (73), possibly due to loss of arborization in receptor endings in these dogs (74).

There is however, one preliminary study showing that the arterial baroreflex may not be responsible for the increase in sympathetic drive. Brandle et al. showed that sino-aortic denervation of paced dogs resulted in the same increase in plasma norepinephrine, compared to paced dogs without denervation. Also, there were no differences in hemodynamics and the progression of heart failure in both groups. Thus, the elimination of the baroreflex resulted in the same sympathetic response to heart failure, suggesting that the baroreflex is not the sole mechanism for the increase in sympathetic drive in heart failure (75).

\section{The vascular $\alpha$ and $\beta$ adrenergic receptor during heart failure}

The arterial vasoconstriction in different vascular beds is mediated by a mixed population of post-junctional vascular adrenoreceptors, mainly of the al subtype $(76,77)$. The $\alpha 2$ receptors are also located extrajunctionally, where they serve as the receptors activated by spill over norepinephrine $(78,79)$. The density of $\alpha 1$ and $\alpha 2$ receptor populations vary widely within different organs and vascular beds. In most species, large conduit arteries mainly possess the $\alpha 1$ receptor, while distal arteries may have equivalent or higher numbers of $\alpha 2$ receptors ( 80 , 81). Presynaptic $a 2$ receptors, however can inhibit norepinephrine release and blunt the vasoconstricting response by attenuating norepinephrine release (80).

Studies on changes in the vascular $\alpha$-adrenergic system during heart failure are 
limited. Goldsmith et al. infused norepinephrine in patients with heart failure. Plasma norepinephrine concentrations increased to $2500 \mathrm{pg} / \mathrm{ml}$ without any effects on blood pressure and heart rate. Similar increases in norepinephrine in normal subjects increased blood pressure and decreased heart rate. The investigators concluded that the peripheral $\alpha_{1}$-receptor pathway may be partially desensitized in heart failure (82). Angus et al. studied skin resistance arteries from patients with congestive heart failure and showed an impaired contraction and relaxation to a variety of agonists, including norepinephrine, angiotensin II and potassium chloride (39). On the other hand, Kubo et al. reported that the $\alpha_{2}$ receptor blocker yohimbine produced comparable increases in forearm blood flow in patients with heart failure in comparison to normal controls (83). A recent study by Indolfi et al. showed that phenylephrine (a selective $\alpha 1$ receptor agonist) and BHT933 (a selective $\alpha 2$ receptor agonist) induced equivalent vasoconstriction of the forearm vascular bed in patients with heart failure and in normal subjects (84). Animal studies on the vascullar responsiveness to adrenergic stimuli are numerous, but very inconsistent. Much seems to depend on the type of arteries investigated, the studied time point after induction of heart failure and the model used. Results vary from increased sensitivity and responsiveness to $\alpha 1$ receptor stimulation to decreased sensitivity to $\alpha 2$ receptor stimulation in large arteries in the paced dog model for heart failure (85). In rats with experimental heart failure, following the induction of myocardial infarction, Bergdahl et al. showed no changes in absolute contractile effect to phenylephrine ( $\alpha 1$ receptor agonist) and a decreased responsiveness to $\alpha_{2}$ receptor stimulation in the largle arteries one month after the induction of myocardial infarction (85). Stassen et al. also found no alterations in contractile reactivity to phenylephrine and norepinephrine of the thoracic aorta (86). One week after induction of myocardial infarction, however, a hyporesponsiveness of the thoracic aorta was observed by Teerlink et al. (35). For the resistance arteries, Feng ef al showed a decreased vascular $\alpha 2$ receptor responsiveness $(87)$, while Stassen et al. also observed a hyporesponsiveness of the mesenteric resistance arteries for $\alpha 1$ receptor stimulation $(86,88)$.

The peripheral vasculature also contains $\beta$-adrenergic receptors, mainly of the $\beta 2$ subtype, which mediate vascular smooth muscle cell relaxation $(89,90)$. A well known feature of heart failure is the downregulation of cardiac $\beta$ receptors, concomitant with a decoupling of these receptors from their second messenger adenylyl cyclase (91-93). Much less is known about the regulation of peripheral vascular $\beta 2$ receptors during heart failure. Creager et al. infused isoproterenol $(\beta$ receptor agonist) into patients with heart failure and into normal subjects. They found that maximal forearm blood flow responses to isoproterenol were comparable in both groups (94). Thus there appears to be no desensitization of the peripheral vascular $\beta$ receptor pathway during human heart failure. In an animal model for heart failure (dogs subjected to cardiac pacing), however, $\beta$ adrenergic receptor density was significantly decreased in membrane 
preparations from mesenteric vessels, without a change in affinity (95).

In summary, data on the status of vascular $\alpha$ and $\beta$ adrenergic receptors during heart failure are far from complete. All together, the data suggest that heart failure is followed by changes in $\alpha$ or $\beta$ adrenergic receptor regulation, but alterations seem to be different depending on the species and the vascular bed examined, as well as the time frame used.

Thus, we are left with the apparent paradox of an increase in sympathetic nervous system activity but attenuated responses to sympathetic stimuli such as orthostatic tilt and a depressed baroreceptor function. Vascular $\alpha$ or $\beta$ adrenergic receptors may change, but data on this topic are still incomplete. Also, other mediators, such as the renin-angiotensin system, may also participate in sympathetic activation during heart failure.

\section{Neurohormonal activation : The natriuretic peptides (a2)}

\section{Introduction}

In 1981, DeBoid et al reported a rapid and potent natriuretic response to intravenous injections of an atrial extract in rats (96). This study formed the basis for the detection of a new peptide family, the natriuretic peptides. It has become clear that this family of natriuretic peptides plays an important role in cardiovascular homeostasis, since its three members, atrial natriuretic peptide (ANP), brain natriuretic peptide (BNP) and C-type natriuretic peptide (CNP), exhibit natriuretic-diuretic, vasorelaxing and other functions operative in lowering blood pressure and the control of electrolyte homeastasis (97).

All three natriuretic peptide are first synthesized as pre-pro-hormones, which are cleaved and activated to yield the biological active peptides (98). The heart is the major source of both plasma ANP and BNP. In the atria, 1-3\% of all mRNA transcripts is ANP mRNA (99). The ANP levels in the ventricles are 50-100 fold lower than in the atria, but ventricular ANP synthesis is increased during cardiac development and disease (100). In the latter situation, it becomes the principal source of plasma ANP, due to the greater mass of the ventricles (101). The level of atrial BNP is $4 \%$ of that of ANP, while the BNPIANP ratio is approximately $30 \%$ in the ventricles (102). CNP is predominantly found in the brain and only very little CNP is found in the heart (100). Recently, it was shown that vascular endothelial cells produce CNP in vitro (103) and the concept of CNP as a 'vascular natriuretic peptide system" has been proposed $(103,104)$.

\section{Biological actions of natriuretic peptides}

The biological actions of the natriuretic peptides are mediated through specific high-affinity receptors, which are divided into two major subtypes, and activate (R1) or not (R2) activate guanylyl cyclase (GC). The R1 receptors are subdivided in GC-A (high affinity for ANP) and GC-B (high affinity for BNP and CNP). The R2 
receptors (equal affinity for ANP, BNP and CNP) account for $90 \%$ of the natriuretic receptors on vascular smooth muscle and endothelial cells and were first regarded as clearance receptors, since they were not coupled to GC and had little natriuretic effect. Subsequent research, however, showed that they were coupled to the adenylyl/cAMP signal transduction system and are more than just clearance receptors (105).

Both ANP and BNP possess potent natriuretic and diuretic effects through actions on the kidney. ANP and BNP increase glomerular filtration rate and filtration fraction by relaxation of afferent arterioles and mild constriction of efferent arterioles, which lead to an increase in glomerular capillary pressure ( 97 , 106). In addition to their renal effect, the natriuretic peptides control blood pressure via their reducing effects on cardiac output (105) (by reducing central venous and left atrial pressure (107)) and relaxing effects on vascular smooth muscle cells $(108,109)$. Other evidence for the important role of the natriuretic peptides on blood pressure regulation comes from a significant correlation between plasma ANP levels and blood pressure variations throughout the day (110).

As mentioned above, CNP may be a more vascular peptide than ANP and BNP. CNP has only minor natriuretic diuretic activity $(111,112)$. Infusion of CNP into dogs caused a more pronounced decrease in blood pressure when compared to ANP (111), but this effect was not seen in humans (113). It is possible that CNP may be a local regulator of vascular tone and growth as transforming growth factor $\beta$ and other cytokines increased the mRNA-expression of CNP in endothelial cells $(103,104)$.

\section{Natriuretic peptides during heart failure}

During heart failure, plasma concentrations of ANP (114-117) and BNP $(114,118$ $120)$ increase in proportion to the clinical severity of the syndrome $(51,120)$. Also, ANP secretion is no longer limited to the atria, but also involves the ventricles (121, 122). Plasma CNP concentrations are normally low and do not seem to increase during heart failure (114).

Infusion of ANP or BNP in humans and animals with heart failure results in a reduction of systemic vascular resistance, enhanced natriuresis and diuresis, inhibition of the activity of the renin angiotensin system and an improved exercise performance (123-126). Several studies however also show attenuated responses to ANP infusion $(124,127-129)$. In fact, the elevated plasma concentrations are at odds with the tendency of patients and animals with heart failure to retain salt and water. One explanation for this apparent discrepancy is a generalized hyporesponsiveness to the effects of ANP/BNP during heart failure. Hirooka et al. showed an attenuated forearm vasodilatory response to intraarterial ANP infusions in patients with severe heart failure (130). Kubo et al. demonstrated a maintenance of vasodilatory response to ANP in the same experimental setting, but their patient group had less severe heart failure (131). 
Abassi et al. showed the same trend in rats with experimental heart faillure due to an aorta-caval fistula. Severely decompensated rats showed progressive sodium retention and edema formation, whereas compensated rats did not. The natriuretic response to exogenous ANP was attenuated only in rats with decompensated heart failure. It was suggested by this group that the renal effects of ANP were overridden by an activation of the renin-angiotensin system in the severely decompensated, sodium-retaining state, as administration of the angiotensin type /-receptor antagonist losartan restored the natriuretic effects of ANP in severely decompensated rats (132). Another explanation may be the possible downregulation of ANP-receptors under high concentrations of ANP $(133,134)$. Tsutamoto et al. showed that the molar ratio of cGMP production to ANP extraction in the peripheral circulation (femoral vascular bed) was significantly lower in patients with severe congestive heart failure and suggested that this may be related to a guanylate cyclase-coupled receptor down regulation (127).

In conclusion, although the natriuretic peptides are a potential counter-regulatory system for the natriuretic and vasoconstricting state seen during heart failure, the relative attenuation of renal responsiveness and the possible downregulation of ANP-receptors may be factors contributing to the development of decompensated heart failure.

\section{Neurohormonal activation : Endothelium derived vasoactive factors (a3)}

The endothelium of blood vessels plays an important role in the regulation of vascular tone. A number of vasoactive substances produced by endothelial cells has been identified, not only relaxing factors such as nitric oxide (NO) and prostacyclin, but also contracting factors such as endothelin, and cyclooxygenase products (thromboxane $A_{2}$, prostaglandin $H_{2}$ and superoxide anions) $(135,136)$. In this outline, endothelin (a3-1), NO (a3-2) and their effects during heart failure are discussed, as it has become clear that imbalances in the production and action of these factors could contribute to the pathophysiology of heart failure.

Endothelium derived vasoactive factors, the endothelins (a3-1)

The endothelins are a family of three related peptides, endothelin (ET) 1,2 and 3 , each 21 amino acids large, of which ET-1 is the best known. ET-2 and ET-3 are closely related to ET-1 ( $80 \%$ homology), with ET-1 and ET-2 being the more potent vasoconstrictors (137). The source of ET-3 is unknown, but may be either neural or endocrine derived. ET-2 has not been detected in human plasma and appears to be synthetised predominantly in the kidney and intestine (138).

ET-1 produces potent and sustained vasoconstrictor and vasopressor actions in both humans and animals. Exposure of vascular endothelial cells to a variety of stimuli, such as adrenaline, thrombin (139), angiotensin II (133), cytokines or 
shear stress (138) causes increased transcription of prepro-ET-1, which is cleaved to yield big ET-1 (140). Big ET-1 is then cleaved to ET-1 by several isoforms of a membrane bound neutral metalloproteinase, endothelin-converting enzyme (ECE) (141). Vascular smooth muscle cells also produce ET-1 in vitro, but at a significantly lower rate than endothelial cells. The relatively greater mass of smooth muscle cells in large arteries probably makes them a major contributor to the local production of ET-1 (142). Plasma concentrations of ET-1 are substantially lower than the concentrations needed to produce direct vasoconstriction in vivo (143). In addition, vascular endothelial cells release more ET-1 towards the basement membrane (abluminally) than luminally (144). Thus in the normal situation, ET-1 appears to be a locally acting paracrine hormone instead of a circulating endocrine hormone.

\section{Biological actions of ET-1}

There are several specific high affinity binding sites for the ETs. The ET-A receptor, is expressed in human aorta (vascular smooth muscle cells), lung, heart and kidney (145) and the ET-B receptor is mainly expressed in the cerebral cortex, cerebellum and endothelial cells (146), but also in human vascular smooth muscle cells (147). The ET-A receptor has a high affinity for ET-1 (binding potency ET-1>ET-2>>ET-3), the ET-B receptor has equal affinity for" all three ETs (138). The ET-A receptor appears to be the major receptor mediating arterial vasoconstriction, while the ET-B receptor mediates the release of endatheliumdependent vasodilating substances. In some resistance and large conduit arteries, the $\mathbb{E T}-\mathrm{B}$ receptor may also contribute to the vasoconstriction $(138,148)$, but this markedly depends on the species, vessel type and vessel size $(147,149)$.

ET-1 produces a long-lasting contraction of larger arteries (139) and contributes to basal vascular tone in man (148). Additionally, infusion of ET-1 in man increases the blood pressure (150). ET-2 and ET-3 also constrict isolated large arteries, although ET-3 is less potent (137).

The vasoconstrictor effect of the endothelins is preceded by an endotheliumdependent transient vasodilation, although this response may be more pharmacological than physiological and does not seem to occur in conditions in which the ET concentration gradually rises, such as after administration of proendothelins (151). Besides its vascular effect, ET-1 has a potent positive inotropic effect (152).

ET-1 also interacts with other local mediators of vascular tone. The ETs stimulate nitric oxide (NO) production in isolated vessels (153) suggesting that there is an autocrine feedback mechanism to modulate the vasoconstricting properties of $\mathrm{ET}$. 1. ET-1 infusions also increase circulating ANP in rats and dogs $(154,155)$, but not in humans (150) and ET-1 potentiates the volume-induced cardiac secretion of ANP (156). In turn, ANP can, like NO, dose-dependently relax ET-1 precontracted vascular strips (157). Also, the production of ET-1 is inhibited by 
ANP and NO $(158,159)$.

\section{Endothelins during heart failure}

Plasma ET-1 concentrations are increased in animal models of heart failure (160164) and patients with heart failure (165-168). ET-1 plasma concentrations correlate with the clinical severity of the syndrome (165-167) and were shown to be a prognostic indicator of mortality (169). However, there is some reservation about the meaning of these correlations as several authors indicated that plasma big ET-1 concentrations are also increased during heart failure $(167,168,170)$. Wei et al. showed that the increase in plasma ET is mainly due to an increase of big ET-1, which is less biologically active. The authors also showed that the increase in total circulating ET is a late phenomenon in human congestive heart failure and correlates with cardiac dysfunction only in the moderately and severely symptomatic heart failure (167). There are at least two studies, showing a relationship between plasma ET-1 and pulmonary, but not central hemodynamics (e.g. cardiac index, total peripheral resistance) $(171,172)$. One of these studies also indicated that the main source of circulating ET-1 is increased ET-1 spillover in the pulmonary vascular bed (172). Although these studies suggest that ET-1 is simply a marker of heart failure, there are several other studies contradicting this assumption. Pacher et al. recently showed that plasma big ET is a better prognostic indicator of mortality in patients with severe congestive heart failure than hemodynamic variables and plasma levels of ANP (170), and several studies showed that plasma ET-1 levels were not normalized after cardiac transplantation (173, 174). Also, Kiowski et al. showed evidence that the high ET-1 plasma concentrations in patients with heart failure contribute to the maintenance of vasoconstriction (175). Studies with ET-1 antagonist also indicate that ET-1 could be more than a marker of heart failure. Sakai et al. demonstrated that long term administration of an ET-A receptor antagonists to rats with myocardial infarction improved survival and cardiac function (176).

In conclusion, an elevation in plasma ET-1 is seen in both human and experimental heart failure. It is not yet clear whether this increase is just a marker for heart failure or is of pathophysiological importance.

Endothelium derived vasoactive substances, nitric oxide (a3-2)

In 1983, Furchgott and Zawadzki were the first to describe the obligatory role of the vascular endothelium in the vasodilating response by acetylcholine. In isolated rabbit aorta segments, precontracted with norepinephrine, acetylcholine produced a relaxation but only if the endathelium was present (177). Subsequently, in 1987 Palmer et al., showed that nitric oxide was (one of) the factor(s) responsible for this endothelium-derived relaxation (27).

The radical NO, with a half live of only $3-5 \mathrm{sec}$, is generated by oxidation of one of the terminal guanidine nitrogen atoms of the amino acid L-arginine (178). The 
reaction is catalyzed by NO-synthase (NOS) of which three isoforms, the endothelial constitutive (ecNOS), the neuronal (nNOS) and the inducible (iNOS) have been identified to date. These NOS's were isolated from vascular endothelial cells, neurons and cytokine-activated macrophages, respectively (179) but the three isoforms are now thought to be present in many tissues and cells, which are also able to express more than 1 isoform (180).

Although expressed in other cells, expression of ecNOS is predominantly found in vascular endothelial cells (179). ecNOS is responsible for a continuously low basal release of NO from the endothelium (181). Next to this basal release, both receptor-dependent and receptor-independent mechanisms enhance the release of NO. Among the receptor-dependent factors are acetylcholine and bradykinin, while factors such as shear stress and hypoxia are receptor-independent (182).

iNOS can also be expressed in a number of cells, including macrophages (183) and vascular smooth muscle cells (184-186). iNOS is activated by inflammatory cytokines such as tumor necrosis factor and interleukin 1 (178). In contrast to ecNOS, iNOS is calcium independent due to the presence of a calmodulin-unit in the iNOS enzyme (187).

\section{Biological actions of NO}

The intravenous administration of analogues of L-arginine which competitively inhibit NO synthase, rapidly increases the arterial blood pressure in animals (188191). This pressor effect is the result of an inhibition of the basal release of NO from the endothelium, indicating that this basal release of NO is important for the regulation of basal vascular tone and blood flow $(29,192)$.

Another important feature of $\mathrm{NO}$ is its effect on myocardial function and contractility. The myocardial endothelium regulates cardiac contractility $(193,194)$ and various studies have suggested a negative inotropic effect of NO or its intracellular messenger cGMP (195-197), although other studies show that physiological concentrations do not exert a major regulatory effect on myocardial contractility (198). The inotropic effects of NO may depend on its concentration (positive inotropy after low concentrations and negative inotropy after high concentration) $(199,200)$.

As for the interactions of NO with other hormonal systems, NO is a negative modulator of ANP secretion (201) and down-regulates the ANP R2 receptor (202). NO is believed to mediate the initial vasodilatory response to ET (203). On the other hand, NO can suppress the production of ET-1 (158) and reduce the affinity of the ET receptor for its ligand (204).

\section{NO during heart failure}

Changes in NO metabolism have been linked to the endothelial dysfunction seen during heart failure. Thus, the stimulated release of NO from the endothelium by agonists such as acetylcholine is impaired in animals and patients with heart failure, whereas the basal release is intact or may be enhanced. Recently, Habib 
et al. infused an inhibitor of NOS, $N^{G}$-monomethyl-1-arginine (L-NMMA) in patients with heart failure and observed that the increase in systemic vascular resistance in response to L-NMMA was greatest in those patients with heart failure who had the highest basal systemic vascular resistance. This suggests that these patients have an enhanced basal production of NO (205). In addition, Winlaw et al. measured plasma nitrate levels, as a stable end-product of NO production, and showed significant increases in patients with heart failure (43). Plasma nitrate levels correlated with the clinical severity of heart failure (44). It should be noted that the study of Habib et al. only included a small number of patients $(n=8)$. Also there is still debate whether plasma nitrate is really a good reflection of the actual NO concentrations in plasma.

Recent reports also show changes in the expression of the various NO synthases during heart failure. Haywood et al. found increased expression of INOS MRNA in the ventricular myocardium of patients with idiopathic dilated cardiomyopathy and in patients with ischemic, and valvular heart disease. The myocardium of these patients also showed diffuse staining with an iNOSantibody, confirming the presence of iNOS protein (206). Habib et al. confirmed the presence of immunoreactivity of iNOS in the hearts of patients with dilated cardiomyopathy and ischemic heart disease (207). DeBeider et al. showed increased activity of the iNOS and ecNOS in ventricular tissue samples of patients with dilated cardiomyopathy (208). However, Thoenes et al. failed to show iNOSprotein expression (by immunoblotting) in patients with idiopathic dilated cardiomyopathy and ischemic heart disease, whereas iNOS-expression was increased in failing hearts of septic patients (209). Recently, Patel et al. showed a decreased expression of $\mathrm{nNOS}$ in the hypothalamus and brainstem of rats with a myocardial infarction. The authors hypothesized that the resulting decrease in NO production in these brain areas could be associated with the increased sympathetic activity during heart failure (210).

In the vasculature, Smith et al. showed a reduced expression of the ecNOS gene in the vascular endothelium of the thoracic aorta of dogs with heart failure due to ventricular pacing (211). Comini et al. also showed a reduced ecNOS protein expression in the endothelium in the aorta of rats with heart failure (due to pulmonary hypertension), but an increase of ecNOS protein expression in the smooth muscle layer. The authors suggested that there may be a shift in ecNOS protein expression from the endothelium towards the underlying smooth muscle layer (212).

If the basal release of NO is enhanced during heart failure, it may represent in concert with ANP, a counter-regulatory mechanism to the vasoconstrictive forces of ET-1, norepinephrine and angiotensin II. The impaired stimulated release of NO may attenuate the above mentioned beneficial effects of NO during heart failure. 


\section{Neurohormonal activation : The renin-angiotensin system (a4)}

\section{Introduction}

Traditionally, the renin angiotensin system (RAS) is regarded as a circulating hormonal system, important in blood pressure control and sodium and potassium homeostasis. Recently, however, components of the enzymatic RAS cascade have been identified in a variety of tissues such as the brain, kidney, reproductive tract, heart and blood vessels (213-216). It is thought that this tissue RAS substantially controlls blood pressure, as well as structure and function of heart and vessels $(215,217,218)$.

The circulating renin-angiotensin system

The first reaction in the renin-angiotensin cascade is the cleavage of liver-derived angiotensinogen by renin in the plasma, whereby angiotensin I (ANG I) is released. The angiotensin-converting enzyme (ACE) catalyzes the cleavage of ANG I into the vasoactive substance angiotensin \|I (ANG II). ACE is widely distributed in organs and vascular endothelium. In physiological conditions, a major site for the conversion of circulating ANG I is the lung $(219,220)$.

The RAS is activated through an increased secretion of renin from the kidneys. The secretion of renin from the juxtaglomerular cells is triggered by renal hypoperfusion, by low sodium loading to the macula densa region of the renal tubuli and by an increase in renal sympathetic tone induced by baroreceptor unloading in response to arterial hypotension or hypovolemia $(219,221)$.

\section{Functions of ANG II}

The most important physiological effects of ANG II are listed in table 1.1. The main function of ANG II is maintenance of blood pressure and electrolyte homeostasis. ANG II increases the blood pressure in several ways. ANG II induces a systemic vasoconstriction, resulting in a pressure increase. In the kidneys, it constricts the efferent and (to a lesser extent) the afferent arterioles; as a result the glomerular filtration pressure will increase; concomitant reduction of the glomerular filtration coefficient results in a net decrease of the glomerular filtration rate. At the same time, it acts on the renal proximal tubules to increase sodium reabsorption. Additionally, ANG II stimulates the adrenal cortex to secrete aldosterone, which acts to retain sodium in the distal nephron, in exchange for potassium. The sodium retention is associated with water retention, thereby increasing whole body fluid volume and increasing arterial blood pressure (219). Finally, ANG II is a potent growth-factor of various cell types, such as cardiac myocytes, endothelial cells and vascular smooth muscle cells $(222,223)$. Infusion of ANG II in normal rats induces a hypertrophic response in peripheral arteries (224-226) even at a non-hypertensive dose $(227,228)$. 
Table 1. Functions of ANG II

Function of ANG ॥

A. Systemic vasoconstriction!

Vasoconstriction in the kidney $\rrbracket$

Aldosterone secretion 1

Renin release

Sympathetic activity 1

B. Stimulation of growth
Physiological effect

Blood pressure I

Renal flow and GFFI

and sodium retention

Sodium retention and kaliuresis

Negative feedback on ANG II

release

Increased noradrenaline release

Hypertrophy of e.g. VSMC,

endothelial cells, cardiac myocytes

Extracellular matrix synthesis
$(222,223)$

Reference

$(232,233)$

$(64,231)$

$(229,230)$

$\uparrow=$ stimulation, $\downarrow$ = inhibition, GFP = Glomerular filtration rate, VSMC = vascular smooth muscle cell

Interactions with other neurohumoral systems

There are extensive interactions between the RAS and other neurohumoral and blood pressure controlling systems, including the sympathetic nervous system. ANG II resets the baroreflex (reviewed in references 64 and 234) and increases the release of epinephrine and norepinephrine $(64,231)$. Additionally, ANG II may act centrally to enhance sympathetic output (235). Local renal ANG II formation may also enhance the action of the sympathetic nerves through pre-synaptic mechanisms (236) and the sympathetic nervous system is a regulator of renin release $(237)$.

The interaction between the sympathetic nervous system and ANG II in peripheral hemodynamics is still unclear. Hilgers et al. reported that neither ACEinhibition nor ANG II receptor antagonism affected the pressor response to nerve stimulation in rats (238). Kline et al. showed that rats with hypertension induced by chronic ANG II infusion had similar norepinephrine turnover rates in several peripheral organs, suggesting these rats do not have enhanced sympathetic tone (239). Also, selective $\alpha 1$ receptor blockade in rats with ANG II induced hypertension did not decrease the blood pressure $(240,241)$. One study found no interaction between $A N G \quad I$ and the sympathetic nervous system in vasoconstrictor reflexes of the (human) forearm (242). Other studies however, did suggest an interaction between the two systems. Lyons et al. showed that the vasoconstrictor action of exogenous ANG II is sympathetically mediated, as 
phentolamine (postsynaptic $\alpha$ receptor blockade) attenuated the vasoconstrictor response to infused ANG II into the brachial artery of healthy volunteers (243). Seidelin et al. also suggested that ANG $\|$ is involved in the sympathetic vasoconstriction in forearm vessels in man (244). Some of the controversy can be explained by the difference between endogenous and chronic infusions of exogenous ANG II: Reid (64) suggested that enhance sympathetic activity does not significantly contribute to the pressor response to exogenous ANG II, while the actions of endogenous ANG II on the sympathetic nervous system enhance the cardiovascular responses elicited by an activation of the sympathetic nervous system.

The endothelium is an important regulator of the activity of the RAS. ET-1 infusions in animals increase renin, aldosterone and adrenaline concentrations $(155,245)$. Furthermore, NO decreases ANG II binding to cultured vascular smooth muscle cells (246), whereas ANG II can inhibit the cytokine induced expression of iNOS in vascular smooth muscle cells (184).

Another important counterregulatory system of the RAS is formed by the natriuretic peptides. Keinert et al. showed that ANP is more effective in antagonizing contractions in rabbit aorta induced by ANG II than those induced by norepinephrine (108). Both in vivo and in vitro, ANP directly reduces basal secretion of renin (247). In humans, ANP inhibits the ANG II stimulated sympathetic nerve activity (248). Also, ANP and BNP inhibit the pressor response to ANG II and blunt the aldosterone response to ANG II in humans $(249,250)$.

The circulating RAS during heart failure

Activation of the circulating RAS has been shown in patients with heart failure $(251,252)$, but plasma renin, ANG II levels or ACE-activity may be normal in the compensated or moderate state of heart failure $(253,254)$. The literature is not consistent on the status of activation of the circulating RAS in experimental heart failure. Most studies show normal plasma levels of plasma renin, ANG II or ACEactivity (255-261), but others demonstrate increased levels of these compounds $(256,262,263)$. The discrepancies may be related to hemodynamic changes, elapsed time after induction of heart failure, the use of medication and the severity of heart failure.

\section{The angiotensin receptors}

At least two distinct types of membrane bound ANG II receptors have been identified, the angiotensin receptor type I and II (AT1 and AT2). All functions of ANG II listed in table 1.1 are AT1 mediated (264-267). There has been a longstanding discussion on the function of the AT2 receptor. The abundance and location of AT2 receptors in young mice suggest that this receptor is involved in growth and fetal development (268). However, 'knock-out' mice with targeted disruption of the AT2 receptor gene show normal fetal development and growth $(269,270)$, which questions the putative role of AT2 receptor in growth and 
development. Attention has also been focussed on a counterbalancing role of the AT2 receptor opposing the blood-pressure and proliferative effects of the AT1 receptor. Data from the AT2 receptor 'knock-out' mice showed that basal blood pressure was increased and that the pressor response to ANG II was enhanced in these animals, suggesting that the AT2 receptor opposed the pressor responses to ANG III $(269,270)$, In the kidney, the AT2 receptor may blunt the blood pressure induced sodium excretion (271). Furthermore, the AT2 receptor mediates an antimitogenic effect on rat coronary endothelial cells (272) and R3T3 cells (273) and may mediate apoptosis (programmed cell death) (274). It has been hypothesized that ANG II can only exert its proliferative effects through the AT1 receptor, but only when either the AT2 receptor is absent (as in certain culture conditions) or inactivated (as during pretreatment with an AT2 antagonist) (275).

Both receptor subtypes belong to the seven-transmembrane family of G-protein coupled proteins. Depending on the cell type, the AT1 receptor is coupled to the activation of phospholipase $A 2, C$ and $D$, as well as voltage-dependent $\mathrm{Ca}^{2+}$ channels and inhibition of adenylate cyclase (276). In addition, the AT1 receptor is directly coupled to kinases initiating tyrosine phosphorylation cascades, like the MAP kinase cascade and the JAK/STAT pathway (277-279). The AT2 receptor is also coupled to a $G$ protein in the rat fetus (280) and in vascular smooth muscle cells transfected with the intracellular third loop domain of the AT2 receptor (281). Siragy and Carey have shown that the AT2 regulates renal cyclic guanosine $3^{\prime \prime}, 5^{\prime}$ monophosphate (cGMP) in the rat kidney (282).

\section{AT-receptors in the cardiovascular system}

Binding studies have identified the AT1 and AT2 receptor in heart tissue. Sechi et al. showed that both receptors were widely distributed throughout the rat heart, with each receptor subtype accounting for approximately $50 \%$ of the specific binding $(283,284)$. In the human heart, receptor density decreases from the right atrium to the left ventricle, with the AT1 receptor accounting for $60 \%$ in both chambers in one study $(285,286)$. A study from Regitz-Zagrosek et al. showed a predominance of the AT2 receptor in the normal human right atrium (287).

The aortic wall of a normal adult rat contains the AT1 and AT2 receptor subtypes in a $4: 1$ ratio $(288,289)$.

\section{AT receptors in the cardiovascular system during heart failure}

In humans, Regitz-Zagrosek et al. showed a significant loss of cardiac AT receptors in end stage, but not in moderate heart failure. The loss of receptors was equal for both receptor subtypes (287). The group of Wang and de Gasparo, however, found a selective downregulation of the AT1 receptor, but not the AT2 receptor in the hearts of transplant recipients (285). Rogg et al. recently reported a decrease in AT1 receptor density and an increased density of the AT2 receptor in atrial tissue in patients with valvular or coronary artery disease (290). Thus, in 
human heart failure, there appears to be a downregulation of the AT1 receptor. The data on the AT2 receptor is controversial, but this may be related to the type of cardiac tissue examined (e.g. atrial versus ventricular) or the stage of heart failure. In animal studies, rats with cardiac hypertrophy due to aortic banding showed AT1 receptor downregulation (291) as did rats with experimental heart failure due to volume overload (aorta caval fistula) (292). Most studies in rats with experimental heart failure due to coronary artery ligation, however, show an upregulation of cardiac AT1 and AT2 receptors (284, 293-295).

There are no studies describing possible changes in the AT receptors in the peripheral vasculature during heart failure.

\section{Local renin-angiotensin systems}

The first indication for the existence of a local-RAS came from a study by Unger et al. who observed a prolonged hypotensive response in rats after withdrawal of chronically administered ACE-inhibitors, despite the early return of plasma ACE activity to normal values (296). Subsequent evidence for a local-RAS in the peripheral vasculature was derived from the detection of renin, angiotensinogen and ACE in the media and adventitia of rat aorta $(213,297$, 298), allowing the local production of ANG II. Campbell and Habener quantified the amount of angiotensinogen mRNA in rat aorta and calculated that the aortic concentration was approximately one-third of the concentration in the liver and significantly higher than that found in the kidney, heart, adrenals or brain (299). ACE concentrations vary markedly in different arteries. Jandeleit et al. showed that the highest concentration of ACE is found in homogenates from mesenteric resistance arteries, with lower concentrations in large conduit arteries, such as the aorta (298).

A role for the local vascular RAS in the regulation of peripheral vascular tone and blood pressure has been proposed $(215,300-302)$. The perfused rat hindlimb releases ANG II under basal conditions (303). In this preparation, it was also shown that ANG II could be generated from a tetradecapeptide renin substrate in the absence of circulating renin $(302,304)$. In humans, local inhibition of ACE in the forearm did not change resting blood flow in volunteers on a normal sodium diet. When the subjects were sodium-depleted, local inhibition of ACE did cause an increase in forearm blood flow. Thus, salt depletion activated not only the circulating RAS but also the local vascular RAS (305). Whether this local vascular RAS is as effective as the circulating RAS is not entirely clear. Vicaut and Hou showed that, in the perfused rat cremaster muscle, circulating renin and angiotensinogen were more effective in inducing arteriolar constriction, than local renin and angiotensinogen (306).

The local RAS of the cardiovascular system during heart failure The circulating RAS is mainly activated in the acute phase of heart failure (e.g. shortly after myocardial infarction) (252). In compensated or mild heart failure, 
Figure 1.1 : Relative contributions of tissue and circulating RAS during heart failure (217)

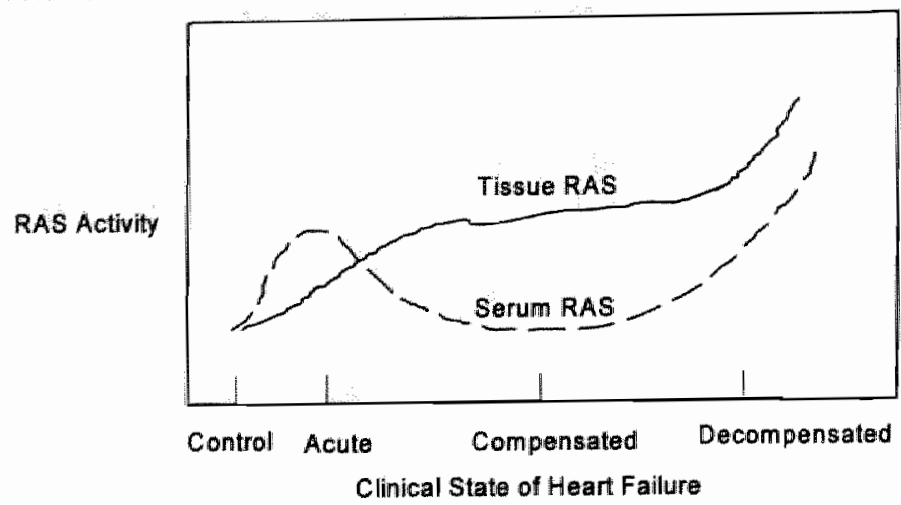

normal or near-normal plasma renin activities and ANG \| values have been reported $(253,254)$. Nevertheless, ACE-inhibition has long term beneficial effects on cardiac remodelling and function in animals and patients with heart failure $(307,308)$. It has been hypothesized by the group of Dzau that the circulating RAS serves to maintain circulatory homeostasis during acute cardiac failure, while the tissue RAS contributes to homeostatic responses during chronic sustained impairment of cardiac function $(217,309$ ) (see figure 1.1).

Several studies show the activation of cardiac RAS during heart failure. Expression of the ACE-gene was increased in the left ventricle in patients with heart failure (310). Animal studies using rats with myocardial infarction also showed an upregulation of cardiac ACE and renin MRNA and ACE activity (258, $311,312)$. In rats with heart failure due to volume overload, similar increases in cardiac mRNA expression for ACE and renin were observed (292).

There is only one study on changes of the components of the vascular RAS during heart failure; Hirsch et al. showed no changes in ACE MRNA expression in the thoracic aorta of myocardial infarcted rats (258).

\section{Possible mechanisms : Vascular structural alterations (b)}

The relation between vascular smooth muscle tone and vascular smooth muscle proliferation

It is important to recognize that the activated neurohormonal systems during heart failure not only regulate vascular tone but also influence proliferation of cells in the vascular wall. The relationships which exist between ANG II, ET-1, NO and ANP in the regulation of vascular tone, also exist for the regulation of vascular growth. Thus, ANG II is a vasoconstrictor and a potent growth-factor for several cardiovascular cell-types, even at low, non-hypertensive doses (222-224, 226228). Norepinephrine induces polyploidization in vascular smooth muscle cells in vitro (313) and infusion of catecholamines increases medial cross-sectional areas in vivo in the rat (314). ET-1 also regulates DNA and protein synthesis, 
expression of protooncogenes (c-fos), cell prolferation and hypertrophy in different celltypes (e.g. cardiomyocytes and vascular smooth muscle cells (315317)). Also, ET-1 acts synergistically with other growth-factors, including plateletderived-growth-factor and transforming growth factors $\alpha$ and $\beta$ to potentiate cellular proliferation (reviewed in reference 317 ).

Vasodilators, such as NO and ANP inhibit vascular endothelium and smooth muscle cell proliferation. Thus, for NO, studies have shown that both exogenous nitrogen vasodilators and inducers of endogenous NO such as interferon- $\gamma$, decrease vascular smooth muscle cell proliferation $(318,319)$. These studies also show that cell proliferation correlated inversely with cyclic GMP (cGMP), making guanylate cyclase and CGMP important second messengers in the antiproliferative effect of $\mathrm{NO}(320,321)$. Furthermore, NO's antimitogenic effects on vascular smooth muscle cells can be modulated by several growth factors. Platelet-derived-growth-factor decreases the induction of NOS and thus the antimitogenic effects of $\mathrm{NO}$, while basic fibroblast growth factor enhances induction of NOS and promotes the antimitogenic effect of NO (320).

The natriuretic peptides are also important counterregulators of the hypertrophic effects of ANG II. The group of Dzau et al. showed that ANP is a potent inhibitor of endothelial and vascular smooth muscle cell growth induced by serum, transforming growth factor $B$ and ANG II $(322,323)$. This anti-proliferative effect is thought to be mediated by the R2-receptor (324). In vivo, infusions of non-hypotensive doses of ANP reduced the structural remodelling (e.g. increase in medial thickness) of the thoracic aorta of spontaneously hypertensive rats (325).

More recently, it was shown by the group of Suga et al. that various cytokines, such as transforming growth factor $\beta$ and tumor necrosis factor, both known as potent vascular smooth muscle cell growth-factors, increase endothelial production of CNP $(103,104)$ and this vascular natriuretic peptide system may play an important role in the vascular growth interaction of endothelial and smooth muscle cells (326).

\section{Vascular structural changes during heart failure}

Vascular structural changes or vascular remodelling have received much attention in hypertension research. Well known is the hypothesis of Folkow (251), that wall thickening in resistance arteries of patients with hypertension takes place at the expense of the lumen. Histological data suggests that vascular remodelling leads to a rearrangement of the tissue mass around a smaller lumen. Thus, crosssectional areas of normotensive and hypertensive vessels may be the same, in spite of a decrease in both internal and external diameters (327).

On the basis of early work of Zelis et al. (328), in which an increase in the arterial vascular sodium content was shown during experimental heart failure, a 'vascular stiffness' component was suggested to explain the reduced maximal vasodilatory response in heart failure. Subsequently, Sinoway et al. showed that 
in patients with heart failure diuretic therapy enhances metabolic vasodilation during exercise. Approximately one-third of the reduced vasodilation could be attributed to increased sodium and water content (329). However, structural alterations may also be involved. Again, Zelis et al. reported increased basement membrane thickness of skeletal muscle capillaries in patients with heart fallure (330). Wroblewski et al also reported microangiopathic alterations in patients with heart failure, resulting from hyalinosis of the basement membranes of terminal skin arterioles $(331,332)$. Lindsay et al, however, measuring diameters, crosssectional areas and endothelial cell areas of these skeletal capillaries, did not find differences between patients with heart failure and normal subjects (333).

Other studies reporting vascular structural changes are limited and mainly consist of measurements of arterial diameters. Arnold et al. showed decreased brachial artery diameters in patients with heart failure (18), while Gabella et al. also reported a decrease in media thickness of a large conduit artery (carotid artery) in rats with myocardial infarction due to coronary artery ligation (14). In contrast, reports on structural changes in the resistance arteries are controversial. In myocardial infarcted rats, Schieffer et al. reported an increase in the medial thickness of resistance arteries of the skeletal muscle bed after 1 year (334). However, in the same model and time frame, there were no changes in medial cross-sectional areas of the femoral and mesenteric resistance arteries (335, 336).

In conclusion, studies on changes in vascular structure during heart failure are limited, but do point to alterations in diameters of large conduit and resistance arteries during heart failure.

\section{Hypothesis}

Peripheral vascular abnormalities during heart failure consist of reduced aortic compliance, excessive peripheral vasoconstriction and endothelial dysfunction. To date, there are few data available on the magnitude of and mechanisms leading to these peripheral vascular abnormalities in heart failure. There is indirect evidence for structural vascular alterations in heart failure, which could explain, at least in part, the observed peripheral functional vascular changes. Since changes in vascular structure depend among others of the ballance between growthstimulating and growth-inhibiting factors, the increased concentrations of several vaso-active agents with different growth-regulating properties could have an important impact on the peripheral vascular structure during heart failure.

Our working hypothesis was that peripheral vascular structural alterations do develop during heart failure and that a resetting of the neurohumoral ballance of vasoconstrictors/growth stimulators and vasodilators/growth inhibitors plays an important role in the development of peripheral vascular structural alterations. In 
view of the increased activity of the RAS, the well-known beneficial effects of ACE-inhibitor therapy, the recently observed abnormalities in NO-related endothelial dysfunction during heart failure and the interaction between the RAS and NO, we focussed on the potential roles of ANG $\|$ and NO on peripheral structural vascular alterations.

\section{This thesis}

In this thesis we studied the development and possible underlying mechanisms of peripheral vascular alterations in experimental heart failure by measuring several morphometric parameters of peripheral vessels (e.g. cross-sectional area, diameters and media-to-lumen ratio) in a rat model for experimental heart failure. The role of neurohormones was investigated by using pharmacological interventions.

In chapter 2, the development of peripheral vascular structural changes of several large conduit arteries and resistance arteries was studied in rats with myocardial infarction and compared to sham operated rats. In chapters 3,4 and 5 , several pharmacological interventions were used to study the possible role of neurohormones. In chapter 3, the hemodynamic and structural effects of ANG II were studied in myocardial infarcted and sham operated rats. In chapter 4 , the role of angiotensin receptors was analysed by co-infusion of ANG II and AT1 and AT2 antagonists and in chapter 5, the possible role of NO was examined by infusing an inhibitor of NO synthase. The findings of these studies are discussed in chapter 6 . 


\section{References}

1. Cohn JN, Sonnenblick EH: Diagnosis and therapy of heart falure, in Schlant RC, Alexander RW (eds): Hurst's, the heart, anteries and weins. New York, USA, McGraw-Hill Inc., 1994, pp. 557571.

2. Francis $\mathrm{GS}_{\text {, }}$ Cohn JN: Congestive heart failure. Pathophysiology and therapy, in Antonaccio M (ed): Cardiovascular Pharmacology, 3rd ed. New York, Raven Press, Lid, 1990, pp. 341-367.

3. Packer M. Pathophysiology of chronic heart failure. Lancet 1992;340:88-92.

4. Pieffer $M A$, Braunwald $E$, Moye $L A$, Basta L, Brown EJ Jr, Cuddy TE, Davis BR, Geltman EM, Goldman S, Flaker GC, et al. Effect of captopril on mortality and morbidity in patients with left ventricular dysfunction after myocardial infarction. Riesults of the survival and ventricular enlargement trial. The SAVE Investigators. $N$ Engl I Med 1992;327: 669-677.

5. The SOLVD investigators. Effect of enalapril on mortality and the development of heart failure in asymptomatic patients with reduced left ventricular ejection fractions. N Engl I Med 1992; $327: 685-691$.

6. Reitsma J日, Mosterd $A_{\mathrm{u}}$ Koster RW, van-Capelle FJ, Grobbee DE, Tijssen $J G$. Increase in the number of admissions due to heart failure in Dutch hospitals in the period 1980-1992. Ned Tijdschr Geneeskd 1994;138:866-871.

7. Gillum RF. Epidemiology of heart failure in the United States [editorial]. Am Heart J 1993:126:1042-1047.

8. Levy D, Wilson PW. Anderson KM, Castelli WP. Stratifying the patient at risk from coronary disease: new insights from the Framingham Heart Study, Am Heant $J 1990 ; 119: 712-717$.
9. Dibianco $R$. The changing syndrome of heart failure: An annotated review as we approach the 21st century. I Hypertens 1994:12:573-S87.

10. Minor WR. Arterial impedance as ventricular afterload. Circ Res 1975;36:565-570.

11. Kass DA, Saeki A, Tunin RS, Recchia FA. Adverse influence of systemic vascular stiffening on cardiac dysfunction and adaptation to acute coronary occlusion. Circulation 1996;93:1533-1541.

12. Babalis D, Levy $B !$ "Azancot I, Masquet C, Beaufils $P$. Ventricular function and arterial compliance in patients with congestive cardiomyopathy. Int $J$ Cardiol 1984; 5:361-364.

13. Eaton GE, Cody RIJ, Binkley PF. Increased aortic impedance precedes peripheral vasoconstriction at the early stage of ventricular failure in the paced canine model. Circulation 1993;88:27142721.

14. Gabella MA, Raya TE, Goldman S. Large artery remodeling after myocardial infarction. Am \& Physiol 1995;268:H2092H2103.

15. Pepine Cd, Nichols WW, Conti CR. Aortic input impedance in heart failure. Circulation 1978;58:460-465.

16. Stetanadis $C_{3}$ Stratos $C$, Boudoulas $H$, Kourouklis C, Toutouzas P. Distensibility of the ascending aorta: comparison of invasive and non-invasive techniques in healthy men and in men with coronary artery disease. Eur Heart $J 1$ 1990;11:990996.

17. Lage SG, Kopel L, Monachini MC, Medeiros $C J$, Pileggi $F$, Polak JF, Creager MA. Carotid arterial compliance in patients with congestive heart failure secondary to idiopathic dilated cardiomyopathy. Am $d$ Cardiol 1994;74:691-695. 
18. Arnold $J M O$, Marchion $G E$, Imrie $J R$, Burton GL, Pflugfelder PW, Kostuk WJ. Large artery function in patients with chronic heart failure. Studies of brachial artery diameter and hemodynamics. Circulation 1991;84:2418-2425.

19. Giannattasio $C$, Failla $M$, Stella $M L$, Mangoni AA, Carugo S, Pozzi M, Grassi G, Mancia G. Alterations of radial artery compliance in patients with congestive heart failure. Am J Cardiol 1995;76:381. 385.

20. Eliakim M, Sapoznikov D, Weinman J Pulse wave velocity in healthy subjects and in patients with various disease states. Am Heart $J 1971 ; 82: 448-457$.

21. Merillon JP, Fontenier $G$, Lerallut JF, Jaffrim MY, Chastret J, Assayag P, Mottet $G$, Gourgon R. Aortic input impedance in heart failure: Comparison with normal subjects and its changes during vasodilatator therapy. Eur Heart $J$ 1984; 5:447-455.

22. Laskey WK, Kussmaul WG, Martin JL, Kleaveland JP, Hirshfeld JW, Shroff S. Characteristics of vascular hydraulic load in patients with heart failure. CircuIation 1985;72:61-71.

23. Zelis R, Mason DT, Braunwald E. Partition of blood flow to the cutaneous and muscular bed of the forearm at rest and during leg exercise in normal subjects and in patients with heart failure. Circ Res 1969;24:799-806.

24. Zelis R, Mason DT, Braunwald E. A comparison of the effects of vasodilator stimuli on peripheral resistance vessels in normal subjects and in patients. with congestive heart failure. $J$ Clin Invest 1968;47:960-970.

25. Reddy HK, Weber KT, Janicki JS, McElroy PA. Hemodynamic, ventilatory and metabolic effects of light isometric exercise in patients with chronic heart failure. I Am Coll Cardiol 1988;12:353-358.
26. Zelis $\mathrm{R}$. Sinoway $\mathrm{Ll}$, Musch $\mathrm{Tl}$, Davis $\mathrm{D}$, Just $H_{2}$. Regional blood flow in congestive heart failure: concept of compensatory mechanisms with short and long time constants. Am J Cardiol 1988;62:2E-8E.

27. Palmer RM $_{\text {" }}$ Ferrige AG, Moncada S. Nitric oxide release accounts for the biological activity of endothelium-derived rellax. ing factor. Nature 1987;327:524-526.

28. Moncada S, Palmer RM, Higgs EA. Nitric oxide: physiology, pathophysiology, and pharmacology. Pharmacol Rev 1991; 43: 109-142.

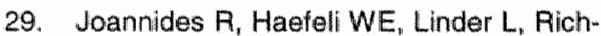
ard $V$, Bakkali $E$, Thuillez C, Lüscher TF. Nitric Oxide is responsible for flow-dependent dilatation of human peripheral conduit arteries in vivo. Circulation 1995; 91:1314-1319.

30. Vane JR, Anggard EE, Bothing FM. Regulatory role of the vascular endothelium. N Engl J Med 1990;323:27-36.

31. Henderson $\mathrm{AH}$. Endothelium in control. Br Heart J 1991;65:116-125.

32. Ontkeam M, Gay $R$, Greenberg B. Diminished endothelium-derived relaxing factor activity in an experimental model of chronic heart failure. Circ Res 1991;69:10881096.

33. Lindsay $D C$, Jiang $C$, Brunotte $F$, Adlamopoulos S, Coats Ad, Rajagopalan $B$, Poole-Wilson PA, Collins P. Impairment of endothelium dependent responses in a rat model of chronic heart fallure: effects of an exercise training protocol. Cardiovasc Res 1992;26:694-697.

34. Teerlink JR, Clozell $M$, Fischli $W$, Clozel JP. Temporal evolution of endothelial dysfunction in a rat model of chronic heart failure. I Am Coll Cardiol 1993; 22:"615-620.

35. Teerlink JR, Gray GA, Clozel M, Clozel $J P$. lincreased vascular responsiveness to norepinephrine in rats with theart failure is 
endothelium dependent. Dissociation of basal and stimulated nitric oxide release. Circulation 1994;89:393-401.

36. Kubo SH, Rector TS, Bank Au, Williams AE, Heifetz SM. Enclothelium-dependent vasodilation is attenuated in patients with heart failure. Circulation 1991; 84: 1589-1596.

37. Katz SD, Blasucci L, Sabba C Strom $J_{A}$ Jondeau $G$, Galvao $M_{i}$ Solomon $S$, Nikolic $S D_{\text {. Forman }} \mathrm{A}_{\text {, Lejemtel }} \mathrm{TH}$. Impaired endothelium-mediated vasodilation in the peripheral vasculature of patients with congestive heart failure. $J$ Am Coll Cardiol 1992;19:918-925.

38. Imaizumi T, Hirooka $Y$, Takeshita A. Decreased skeletal muscle vasodilation in patients with congestive heart failure. Jph Circ J 1992;56:500-503.

39. Angus JA, Ferrier CP, Sudhir K, Kaye DM, Jennings GL. Impaired contraction and relaxation in skin resistance arteries from patients with congestive heart faillure. Cardiovasc Res 1993;27:204-210.

40. Hirooka $Y$, Imaizumi $T$, Harada $S$, Masaki $H$, Momohara $M$, Tagawa $T$, Takeshita A. Endothelium-dependent forearm vasodilation to acetyicholine but not to substance $P$ is impaired in patients with heart failure. $J$ Cardiovasc Pharmacol 1992;20 Suppl 12:S221-\$225.

44. Drexler H, Hayoz D, Münzel T, Hornig B. Just $H$, Brunner HR, Zelis $A$. Endothelial function in chronic congestive heart failure. Am J Cardiol 1992;69: $1596-1601$

42. Kubo SH, Rector TS, Bank AJ, Raij L, Kraemer MD, Tadros P. Beardslee $M$, Garr MD. Lack of contribution of nitric oxide to basal vasomotor tone in heart failure. Am J Cardiol 1994;74:11331136.

43. Winlaw DS, Smythe $\mathrm{GA}_{\text {n }}$ Keogh $\mathrm{AM}$, Schyvens CG, Spratt PM, MacDonald PS. Increased nitric oxide production in heart failure. Lancer 1994;344:373-374.

44. Winlaw DS, Smythe GA, Keogh AM, Schryvens CG, Spratt PM, MacDonald PS. Nitric oxide production and heart failure. Lancet 1995;345:390-391.

45. Levine TB, Francis GS, Goldsmith SR, Simon AB, Cohn JN. Activity of the sympathetic nervous system and renin-angiotensin system assessed by plasma hormone levels and their realation to hemodynamic abnormalities in congestive heart failure. Am J Cardiol 1982;49:16591666.

46. Davis $D$, Baily $R$, Zelis R. Abnormalities in systemic norepinephrine kinetics in human congestive heart failure. Am I Phy. siol 1988;254:E760-E766.

47. Pierpont GL, Francis GS, DeMaster EG, Olivari MT, Ring WS, Goldenberg IF, Reynolds $S$, Cohn JN. Heterageneous myocardial catecholamine concentrations in patients with congestive heart failure. Am J Cardiol 1987;60:316-321.

48. Hasking Gd, Esler MD, Jennings GL, Burton D, Johns JA, Korner PI. Norepineph. rine spillover to plasma in patients with congestive heart failure: evidence of increased overall and cardiorenal sympathetic nervous activity. Circulation 1986; 73:615-621.

49. Leimbach WN Jr, Wallin $B G$, Victor RG, Aylward PE, Sundlof G, Mark AL. Direct evidence from intraneural recordings for increased central sympathetic outflow in patients with heart failure. Circulation 1986;73:913-919.

50. Anand IS, Kalra GS, Harris P, Poole-WIson PA, Panzali A, De-Giuli F. Ferrari $A$. Diuretics as initial and sole treatment in chroric cardiac failure. Cardioscience 1991;2:273-278.

51. Swedberg K, Eneroth P, Kjekshus J, Wilhelmsen $L$. Hormones regulating cardiovascular function in patients with severe congestive heart failure and their 
relation to mortality. Circulation 1990; 82:1730-1736.

52. Francis $G S$, Cohn JN, Johnson $G$, Rector TS, Goldman S, Simon A. Plasma norepinephrine, plasma renin activity and congestive heart failure. Relations to survival and the effects of therapy in V-HeFT II. Circulation 1993;87:V/40. VII48.

53. Cohn JN, Levine TB, Olivari MT, Garberg $V$, Lura D, Francis GS, Simon AB, Rector T. Plasma norepinephrine as a guide to prognosis in patients with chronic congestive heart failure. $N$ Engl $J$ Med 1984:311:819-823.

54. Davis D, Sinoway Ll, Robison J, Minotti JA, Day FP, Baily R, Zelis R. Norepinephrine kinetics during orthostatic stress in congestive heart failure. Circ Res 1987;61:187-190.

55. Goldsmith $\mathrm{SF}_{y}$ Francis GS, Levine $\mathrm{TB}$, Cohn JN. Regional blood flow response to orthostasis in patients with congestive heart failure. J Am Coll Cardiol 1983; 1:1391-1395.

56. Levine TB, Francis GS, Goldsmith SR, Cohn JN. The neurohumoral and hemodynamic response to orthostatic tilt in patients with congestive heart failure. Circulation 1983;67:1070-1075.

57. Francis GS, Goldsmith SA, Ziesche $S$, Nakajima $\mathrm{H}_{*}$ Colhn JNN. Relative attenuation of sympathetic drive during exercise in patients with congestive heart failure. $J$ Am Coll Cardiol 1985;5:83:-839.

58. Ferguson DW, Abboud FM, Mark AL. Selective impairment of baroreflex-mediated vasoconstrictor responses in patients with ventricular dysfunction. Circulation 1984;69:451-460.

59. Kassis E, Jacobsen TN, Mogensen F, Amtorp O. Sympathetic reflex control of skeletal muscle blood flow in patients with congestive heart failure: evidence for beta-adrenergic circulatory controll.
Circulation 1986;74:929-938.

60. Wilson $\mathrm{JP}_{0}$ Matthai $W$, Lanoce $\mathrm{V}$, Frey $M$, Ferraro N. Effect of experimental heart failure on peripheral sympathetic vasoconstriction. Am J Physiol 1988; 254: H727-H733.

61. Zucker $\mathbb{H}$. Wang $W$, Brandle $M$, Schultz HD, Patel KP. Neural regulation of sym. pathetic nenve activity in heart failure. Prog Cardiovasc Dis 1995;37:397-414.

62. Hirsch AT, Dzau VJ, Creager MA. Baroreceptor function in congestive heart failure: effect on neurohumoral activation and regional vascular resistance. Circulation 1987;75:IV36-IV48.

63. Creager MA, Creager SJ. Arterial baroreflex regulation of blood pressure in patients with congestive heart failure. J Am Coll Cardiol 1994;23:401-405.

64. Rieid IA. Interactions between ANG II, sympathetic nerwous system and baroreceptor reflexes in regulation of blood pressure. Am J Physiol 1992;262:E763E778.

65. Higgins $\mathrm{CB}$, Vatner SF, Eckberg $\mathrm{DL}$, Braunwald $E$. Alterations in the baroreceptor reflex in conscious dogs with heart failure. J Clin lovest 1972;51:715-724.

66. Ellenbagen KA, Mohanty PK, Szentpetery S, Thames MD. Arterial baroreflex abnop. malities in heart failure: reversal after opthotopic transplantation. Circulation 1989; 79:51-58.

67. Wroblewski H. Kastrup J, Mortensen SA, Haunso S. Abnormal baroreceptor-mediated vasodilation of the peripherall circulation in congestive heart failure secondary to idiopathic dilated cardiomyopathy. Circulation 1993;87:849-856.

68. Meyrelles SS, Mill JG, Cabral AM, Vasquez EC. Cardiac baroreflex properties in myocardial infarcted rats. $J$ Auton Nen Syst 1996;60:163-168. 
69. Schwartz PS, Zaza $A$, Pala $M$, Locati $E$, Beria G, Zancheti A. Baroreflex sensitivity and its evolution during the first year after myocardial intarction. I Am Coll Cardiol 1988;12:629-636.

70. Olivier NB, Stephenson RB. Characterization of baroretlex impaiment in conscious dogs wh pacing-induced heart fallure. Am J Physiol 1993;265:A1 i32R1140.

71. Levine TB, Olivari MT, Cohn JN. Effects of orthotopic heart iransplantation on sympathetic control mechanisms in congestive heart failure. Am I Cardiol 1986; $58: 1035-1040$.

72. Wroblewski $H_{*}$ Mortensen SA, Haunso $S$, Kastrup J. Orthotopic cardiac transplantation reverses abnormal reflex regulation of the microvasculature in the lower leg. Cardiovasc Res 1994,28: $1707-1712$.

73. White CW. Reversibility of abnormal arterial baroreflex control of heart rate in heart failure. Am I Physiol 1981;241: H778-H782.

74. Zucker IH, Earle AM, Gilmore JP. The mechanism of adaptation of left atria stretch receptors in dogs with chronic congestive heart failure. \ Clin invest $1977 ; 60: 323-331$

75. Brandle M, Patel KP. Wang W, Zucker IH. Hemodynamic and norepinephrine responses to pacing-induced heart failure in conscious sinoartic-deervated dogs. I Appl Physiol 1996;81:18551862.

76. Auffolo RA Jr, Heble JP. Alpha adrenoceptors. Pharmacol Ther 1994;61: $1-64$.

77. Brown Mu. Investigation of alpha 2adrenoceptors in thumans. $A m$ \& Med $1989,87: 65-95$

78. Auffolo RR Jr. Spare alpha adrenoceptors in the peripheral cinculation: excitation-contraction coupling. Fed
Proc 1986:45:2341-2346.

79. Hieble JP, Sulpizio AC, Nichols $A d_{\text {, }}$ DeMarinis RM, Pfeiffer FR, Lavanchy PG. Ruffolo RR Jr. Pharmacological differentiation of pre- and post-junctional alpha 2ardrenoceptors. I Hypertens Supp/ 1986; 4:S189-S192.

80. Leier CV, Binkley PF, Cody RJ. Alphaadrenergic component of the sympathetic nervous system in congestive heart failure. Circulation 1990;82:168-176.

81. Flavaham NA, Cooke JP, Shepherd JT, Vanhoutte PM. Human postunctional alpha- 1 and alpha-2 adrenoceptors: differential distribution in arteries of the limbs. I'Pharmacol Exp Ther 1987; 241:361-365

82. Goldsmith SR, Francis GS, Cohn JN. Norepinephrine infusions in congestive heart failure. Am I Cardiol 1985;56:802804 .

83. Kubo SH, Rector TS Heifetz SM, Cohn IN. Alpha 2-receptor-mediated vasoconm striction in patients with congestive heart failure. Circulation 1989;80:1660-1667.

84. Indolfi $C$, Maione $A$, Volpe $M_{\text {, Rapac- }}$ ciuclo A, Esposito G, Ceravolo $A_{\text {, Ren- }}$ dina $V$, Condorelli $M$, Chiariello M. Forearm vascular responsiveness to alpha 1. and alpha 2-adrenoceptor stimulation in patients with congestive heart failure. Cir. culation 1994;90:17-22.

85. Bergdahl $A$, Valdemarsson $S$, Pantev $E$, Ottosson A, Feng QP, Sun XY, Hedner $T$, Edvinsson L. Modulation of vascular contractile responises to alpha 1- and alpha 2-adrenergic and neuropeptide $Y$ recep. lor stimulation in rats with ischaemic heart fallure. Acta Physiol Scand $1995 ; 154: 429-437$.

86. Stassen FRM, Fazzi GE, Leenders PJA Smits JFM, De Mey JGR. Coronary anerial hyperneactivity and mesenteric anterial hyporeactivity after myocardial infarction in the rat. 1996: submitted for publication. 
87. Feng $Q P$, Bergdah $A$, Lu $X P$, Sun $X Y$, Edvinsson L, Hedner T. Vascular $\alpha-2$ adrenoceptor function is decreased in rats with congestive heart failure. Cardiovasc Res 1996;31:577-584.

88. Stassen FRM, Willemsen MJJMF, Janssen GMJ, Fazzi GE, Schiffers $\mathrm{PMH}$ Smits JFM, De Mey JGR. Reduced responsiveness of peripheral resistance artery smooth muscle to $\alpha-1$ adrenoreceptor stimulation and calcium at 5 weeks after myocardial infarction in the rat. 1996; submitted for publication.

89. O'Donnell SR, Wanstall JC. Responses to the beta 2-selective agonist procaterol of vascular and atrial preparations with different functional beta-adrenoceptor populations. $\mathrm{Br} \backsim$ Pharmacol 1985;84:227-235.

90. Brodde OE. Physiology and pharmacolagy of cardiovascular catecholamine receptors: implications for treatment of chronic heart failure. Am Heart $J$ 1990; 120:1565-1572.

91. Bristow MR, Minobe WA, Raynolds MV, Port JD, Rasmussen R, Ray PE, Feldman AM. Reduced beta 1 receptor messenger RNA abundance in the failing human heart. J' Clin Invest 1993; 92:2737-2745.

92. Bristow MR. Changes in myocardial and vascular receptors in heart failure. $\downarrow / A m$ Coll Cardiol 1993;22:61A-71A.

93. Insel PA. $\beta$-adrenergic receptors in heart failure. J Clin Invest 1993;92: 2564.

94. Creager MA, Quigg RJ, Ren CJ, Roddy MA, Colucci WS. Limb vascular responsiveness to beta-adrenergic receptor stimulation in patients with congestive heart failure. Circulation 1991;83:18731879 .

95. Kiuchi $K$, Sato $N$, Shannon RP, Vatner DE, Morgan K, Vatner SF. Depressed beta-adrenergic receptor and endothelium-mediated vasodilatation in conscious dogs with heart failure. Ciro Res 1993;73:1013-1023.

96. de Bold $A$, Borenstein $M B$, Veress AT, Sonnenberg H. A rapid and potent natriuretic response to intravenous injection of atrial myocardial extract in rats. Life $\mathrm{Scl}$ $1981 ; 28: 89-94$.

97. McDowell G, Shaw $\mathrm{C}$, Buchanan KD, Nicholls DP. The natriuretic peptide tamily. Eur J Clin invest 1995:25:291-298.

98. Wilkins MR, Nunez DJ, Wharton J. Review - The natriuretic peptide family Turning hormones into drugs. $J$ Endocrinol 1993; 137:347-359.

99. Seidman CE, Bloch KD, Zisfein J, Smith JA, Haber $E_{n}$ Homcy $C_{n}$ Duby AD, Choi E, Graham AM, Seidman JG. Molecular studies of the atrial natriuretic factor gene. Hypertension 1985;7:131-134.

100. Takahashi $T$, Allen $P D_{1}$, lzumo S. Expression of A-, B-, and C-type natriuretic peptide genes in failing and developing human ventricles. Correlation with expression of the $\mathrm{Ca}(2+)$-ATPase gene. Circ Res 1992;71:9-17.

101. Yasue $H$, Obata $K$, Okumura $K$, Kurose $M_{0}$ Ogawa $H_{n}$ Matsuyama $K_{2}$ Jougasaki $M$, Saito $Y$, Nakao $K$, Imura $H$. Increased secretion of atrial natriuretic polypeplide from the left ventricle in patients with dilated cardiomyopathy. I Clin Invest 1989; 83:46-51.

102. Nakao $K$, Itoh $H$, Kambayashi $Y$, Hosoda $K$, Saito $Y$, Yamada T, Mukoyama M, Aral

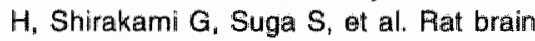
natriuretic peptide. Usolation from rat heart and tissue distribution. Hypertension 1990;15:774-778.

103. Suga $S$, Nakao $K$, ltoh $H$, Komatsu $Y$, Ogawa $Y$. Hama $N_{\text {, }}$ Imura $H$. Endothelial production of C-type natriuretic peptide and its marked augmentation by transforming growth factor-beta. Possible existence of "vascular natriuretic peptide sys- 
tem". J Chin hwest 1992,90:1145-1149.

104. Suga $S$, ltoh $H$, Komatsu $Y$, Ogawa $Y$, Hama $N_{\text {, }}$ Yoshimasa $T$, Nakao $K$. Cytokine-induced C-type natriuretic peptide (CNP) secretion from vascular endothelial celis-evidence for CNP as a novel autocrine/paracrine regulator from endothelial cells. Endocrinology 1993; 133:3038-3041.

105. Anand-Srivastava MB; Trachte GJ. Atrial natriuretic factor receptors and signal transduction mechanisms. Pharm Rev 1993;45:455-497.

106. Laragh $\mathrm{JH}$. Atrial natriuretic hormone, the renin-aldosteron axis, and blood pressure-electrocyte homeostasis. $N$ Engl I Med 1985;313:1330-1340.

107. Lappe RW, Smits JFM, Todt JA, Debets JJM, Wendt RL. Failure of atriopeptin II to cause arterial vasodilation in the conscious rat. Circ Res 1985;56:606-612.

108. Kleinert HD, Maack T, Atlas SA, Januszewicz A, Sealey JE, Laragh JH. Atrial natriuretic factor inhibits angiotensin-, norepinephrine-, and potassiuminduced vascular contractility. Hypertension 1984;6:1143-1147.

109. Winquist $R J_{\text {, Faison }} E P$, Waldman $S A$, Schwartz $K$, Murad $F$, Rapoport RM. Atrial natriuretic factor elicits an endothelium-independent relaxation and activales particulate guanylate cyclase in vascular smooth muscle. Proc Nat! Acad Sci U S A 1984;81:7661-7664.

110. Sothern RB, Vasely DL, Kanabrocki EL, Bremner FW, Third JL, Boles MA. Nemchausky $\mathrm{BM}$ Olwin $J H$. Scheving $L E$. Blood pressure and atrial natriuretic peptides correlate throughout the day. Am Heart J 1995;129:907-916.

111. Clavell AL, Stingo AJ, Wei $\mathrm{CM}_{2}$ Heublein DM. Bumett $\mathrm{JC}$. C.Type natriuretic peptide - A selective cardiovascular peptide. Am I Physiol 1993;264:R290R295.
112. Stingo $A$, , Clavell $A L$, Aarhus $L L$, Bumett JC Jr. Cardiovascular and renal actions of C-type natriuretic peptide. Am J Physiol 1992;262:H308-H312.

113. Cargill RI, Struthers AD, Lipworth B.l. Human c-type natriuretic peptide: effects an the haemodynamic and endocrine responses to angiotensin II. Cardiowasc Ries 1995;29:108-111.

114. Wei $C M$, Heublein DM, Perrella MA, Lerman A, Rodeheffer RJ, McGregor CGA, Edwards WD, Schaff $H V$, Burnett $J C$. Natriuretic peptide system in human heart failure. Circulation 1993;88:1004-1009.

115. Omland $T$, Aarsland $T$, Aakvaag $A$, Live FT, Dickstein K. Prognostic value of plasma atrial natriuretic factor, norepinephrine and epinephrine in acute myocardial infarction. Am J Cardiol 1993;72:255-259.

116. Lerman A, Gibbons RJ, Rodeheffer RJ, Bailey KR, McKinley LJ, Heublein DM, Burnett JC. Circulating N-terminal atrial natriuretic peptide as a marker for symptomless left-ventricular dysfunction. Lancet 1993;341:1105-1109.

117. Riegger GA, Elsner D, Kromer EP, Daffner $C$, Forssmann WG, Muders F, Pascher EW, Kochsiek K. Atrial natriuretic peptide in congestive heart failure in the dog: plasma levels, cyclic guanosine monophosphate, ultrastructure of atrial myoendocrine cells and hemodynamic, hormonal and renal effects. Circulation 1988;77:398-406.

118. Morita $E$, Yasue $H$, Yoshimura $M$, Ogawa $H$, Jougasaki M. Matsumura T, Mukoyama $M$, Nakao $K$. Increased plasma levels of brain natriuretic peptide in patients with acute myocardial infarction. Circulation 1993;88:82-91.

119. Wei CM, Kao PC, Lin JT Heublein DM, Schaff HV, Burnett JC. Circulating betaatrial natriuretic factor in congestive heart failure in humans. Circulation 1993; 88: 1016-1020. 
120. Richards $A M$, Crozier IG, Yandle $T G$, Espiner EA, Ikram H. Nicholls MG. Brain natriuretic factor - Regional plasma concentrations and correlations with haemodynamic state in cardiac disease. Br Heart J 1993;69:414-417.

121. Yasue $H$, Yoshimura $M_{\text {, Sumida }} H_{1}$ Kikuta $K$, Kugiyama $K$, Jougasaki $M$,

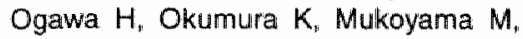
Nakao K. Localization and mechanism of secretion of $B$-type natriuretic peptide in comparison with those of A-type natriuretic peptide in normal subjects and patients with heart failure. Circulation 1994;90:195-203.

122. Yoshimura $M$, Yasue $H$, Okumura $K$,

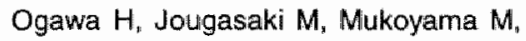
Nakao $K$, Imura $H$. Different secretion patterns of atrial natriuretic peptide and brain natriuretic peptide in patients with congestive heart failure. Circulation 1993;87:464-469.

123. Yoshimura $M$, Yasue $H$, Morita $E$, Sakaino $N$, Jougasaki $M$, Kurose $M$, Mukoyama M, Saito $Y$, Nakao K, Imura $H$. Hermodynamic, renal, and hormonal responses to brain natriuretic peptide infusion in patients with congestive heart lailure. Circulation 1991;84:1581-1588.

124. Scriven TA, Burnett JC. Effects of synthetic atrial natriuretic peptide on renal function and renin release in acute experimental heart failure. Circulation 1985;72:892-897.

125. Saito $Y$, Nakao $K$, Nishimura $K$, Sugawara $A$, Okumura $K$, Obata $K$, Sonoda $A_{\text {, Ban }} T$, Yasue $H$. Imura $H$. Clinical application of atrial natriuretic polypeptide in patients with congestive heart failure: beneficial effects on left ventricular function. Circulation 1987:76:115124.

126. Clarkson PBM, Wheeldon $\mathrm{NM}_{\text {, }}$ MacFadyden RJ, Pringle SD, MacDonald TM. Effects of brain natriuretic peptide on exercise hemodynamics and neurohormones in isolated diastolic heart failure. Circulation 1996;93:20372042.

127. Tsutamoto $T$, Kanamori $T$, Morigami $N$, Sugimoto $Y$, Yamaoka $O$, Kinoshita $M$. Possibility of downregulation of atrial natriuretic peptide receptor coupled to guanylate cyclase in peripheral vascular beds of patients with chronic severe heart failure. Circulation 1993;87:70-75.

128. Drexler $H$, Finkh $M$, Hoing $S$, Toth $M$, Just $H$, Lang RE. Systemic and regional vascular effects of atrial natriuretic peptide in a rat model of chronic heart failure. Basic Res Cardiol 1987;82:517-529.

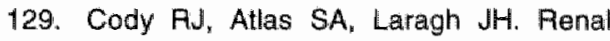
responses to atrial natriuretic factor in patients with congestive heart failure. Eur Heart J 1988;9:29-33.

130. Hirooka $Y$, Takeshita $A$, Imaizumi $T$, Suzuki $S$, Yoshida M, Ando $S$, Nakamura M. Attenuated forearm vasodilative response to intra-arterial atrial natriuretic peptide in patients with heart failure. Circulation 1990;82:147-153.

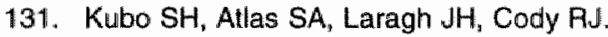
Maintenance of forearm vasodilator action of atrial natriuretic factor in congestive heart failure secondary to ischemic or idiopathic dilated cardiomyopathy. Am J Cardiol 1992;69:1306-1309.

132. Abassi ZA, Kelly $G$, Golomb $E_{\text {, Klein }} H_{\text {, }}$ Keiser HR. Losartan improves the natriuretic response to ANF in rats with highoutput heart failure. I Pharmacol Exp Ther 1994;268:224-230.

133. Emori $T$, Hirata $Y$, Ohta $K$, Kanno $K$, Equchi S, Imai T, Shichiri M, Marumo F. Cellular mechanism of endothelin- 1 release by angiotensin and vasopressin. Hypertension 1991;18:165-170.

134. Ito $H$, Hirata $Y$, Adachi $S$; Tanaka $M$,

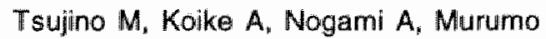
F, Hiroe M. Endothelin-1 is an autocrine /paracrine factor in the mechanism of angiotensin II-induced hypertrophy in cul- 
tured rat cardiomyocytes. I Clin Invest $1993 ; 92: 398-403$.

135. Luscher tf $f_{\text {, Boulanger }} C_{\text {, }}$ Yang $Z$, Noll $G$, Dohi $Y$. Interactions between endothellum-derived relaxing and contracting factors in health and disease. Circulation 1993;87:V36-V444.

136. Vanhoutte PM. Other endothellum-deriwed vasoactive factors. Circulation 1993:87:V9-V17.

137. Inoue $A_{*}$ Yanagisawa $M_{*}$ Kimura $S$, Kasuya $Y_{\text {, Miyauchi }} T_{\text {, Goto }} K_{n}$ Masaki $T$. The human endothelin family: three structurally and pharmacologically distinct isopeptides predicted by three separate genes. Proc Natl Acad Sci US A $1989 ; 86: 2863-2867$.

138. Haynes WG, Webb D.J. The endothelin familly of peptides: local hormones with diverse roles in health and disease? Clin Sci 1993;84:485-500.

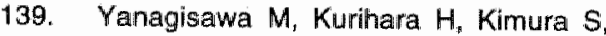
Tomobe $Y$, Kobayashi M, Mitsuj $Y$, Yazaki $Y$, Goto $K$, Masaki T. A novel potent vasoconstrictor peptide produced by vascular endothelial cells. Nature 1988;332:411-415.

140. Haynes WG. Endothelins as regulators of vascular tone in man. Clin Sci 1995 88:509-517.

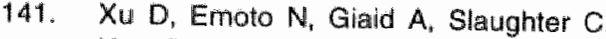
Kaw $S$, deWit $D_{n}$ Yanagisawa $M$. ECE-1: a membrane-bound metalloprotease that catalyzes the proteolytic activation of big endothelin-1. Cell 1994;78:473. 485 .

142. Resink TJ, Hahn AW, Scott-Burden T, Powell J, Weber E, Buhler FR. Inducible endothelin mRNA expression and peptide secretion in cultured human vascular smooth muscle cells. Biochem Biophys Res Cammun 1990;168:1303. 1310.

143. Haynes WG, Clarke JG, Cockcroft JR,
Webb DJ. Pharmacology of endothelin-1 in vivo in humans. I Cardiovasc Pharmacol 1991:17:S284-S286.

144. Yoshimoto $S$, Ishizaki $Y$, Sasaki $T$, Murota $S$. Effect of carbon dioxide and oxygen on endothelin production by cultured porcine cerebral endothelial cells. Stroke 1991:22:378-383

145. Hosoda $K$, Nakao $K$, Arai $H$, Suga $S I$, Ogawa $Y$, Mukoyama $M_{n}$ Shirakami $G$. Saito $Y$, Nakanishi $S$, Imura $H$. Cloning and expression of human endothelin-1 receptor cDNA. FEBS Lett 1991;287:2326.

146. Ogawa $Y$, Nakao K, Arai $H$, Nakagawa $O$. Hosoda K, Suga S, Nakanishi S, Imura H. Molecular cloning of a non-isopeptideselective human endothelin receptor. Biochem Biophys Res Commun 1991; 178: 248-255.

147. Davenport AP, Maguire JU. Is endothelininduced vasoconstriction mediated only by ETA receptors in humans? Trends Pharmacol Sci 1994;15:9-11.

148. Haynes WG. Webb DJ. Contribution of endogenous generation of endothelin- 1 to basal vascular tone. Lancet 1994; 344: 852-854.

149. Deng LY, Li JS, Schiffrin EL. Endothelin receptor subtypes in resistance anteries from humans and rats. Cardiovasc Res 1995:29:532-535

150. Vierhapper $H$, Wagner $O$; Nowotny $P$, Waldhaus $W$. Effect of endothelin- 1 in man. Circulation 1990;81:1415-1418.

151. Gardiner SM, Kemp $P A_{\text {" }}$ Compton $A M$, Bennett $T$. Coeliac haemodynamic effects of endothelin-1, endothelin-3, proendothelinm 1 [1-38] and proendothelin. $3[1-41]$ in conscious rats. Br U Pharmaco $1992 ; 106: 483-488$

152. Kramer BK, Smith TW, Kelly RA. Endothelin and increased contractility in adult rat ventricular myocytes. Riole of 
intracellular alkalosis induced by activation of the protein kinase $\mathrm{C}$-dependient $\mathrm{Na}(+)-\mathrm{H}+$ exchanger. Circ Res 1991; 68:269-279.

153. Warner TD, Mitchell JA, de-Nucci G, Vane JR. Endothelin-1 and endothelin-3 release EDRF from isolated perfused arterial vessels of the rat and rabbit. $J$ Cardiovasc Pharmacol 1989;13:S85S88.

154. Stasch JP. Hirth-Dietrich $C$, Kazda $S$, Neuser D. Endothelin stimulates release of atrial natriuretic peptides in vitro and in vivo. Life Sci 1989;45:869-875.

155. Miller WL, Redfield MM, Burnett JC Jr. Integrated cardiac, renal, and endocrine actions of endothelin. $J$ Clin invest 1989;83:317-320.

156. Donckier J, Hanet $C$, Galanti L, Stoleru L, Van-Mechelen $H$, Robert A, Ketelslegers $J \mathbf{M}$, Pouleur $H$. Low-dose endothelin-1 potentiates volume-induced secretion of atrial natriuretic factor. Am I Physiol 1992;263:H939-H944.

157. Bonhomme $M C$ 。 Cantin $M_{*}$ Garcia $\mathbb{R}$. Relaxing effect of atrial natriuretic factor on endothelin-precontracted vascular strips. Proc Soc Exp Biol Med 1989; 191:309-315.

158. Boulanger C, Luscher TF. Release of endothelin from the porcine aorta. Inhibition by endothelium-derived nitric $O x$ ide. J Clin Invest 1990;85:587-590.

159. Saijonmaa $O$, Ristimaki $\mathbf{A}_{8}$ Fyhrquist $F$. Atrial natriuretic peptide, nitroglycerine, and nitroprusside reduce basal and stimulated endothelin production from cultured endothelial cells. Biochem Biophys Res Commun 1990;173:514520.

160. Sakai S, Miyauchi T, Sakurai T, Kasuya $Y$, Ihara M, Yamaguchi I, Goto K, Sugishita $Y$. Endogenous endothelin-1 participates in the maintenance of cardiac function in rats with congestive theart failure: Marked increase in endathelin-1 production in the failing Meart. Circulation 1996;93:1214-1222.

161. Teerlink JR, Loffler BM, Hess P, Maire JP, Clozel M, Clozel JP. Role of endothelin in the maintenance of blood pressure in conscious rats with chronic heart fail ure. Acute effects of the endothelin receptor antagonist Ro 47.0203 (bosentan). Circulation 1994;90:2510-2518.

162. Löffler BM, Roux S, Kalina B, Clozel M, Clozel JP. Influence of congestive heart failure on endothelin levels and receptors in rabbits. I Mol Cell Cardiol 1993; 25:407-416.

163. Gauquelin $G$, Thibault $G_{4}$ Garcia R. Renal glomerular endothelin receptors in rats with high-output heart failure. Regut Pept 1991; 35:73-79.

164. Miyauchi $T$, Sakai $S$, Ihara $M$, Kasuya $Y$, Yamaguchi I, Goto $K$, Sugishita $Y$. Increased endothelin- 1 binding sites in the cardiac membranes in rats with chronic heart failure. J Cardiovasc Pharmacol 1995;26:S448-S451.

165. Good JM, Nihoyannopoulos P, Ghatei $M_{A}$ Crossman D, Bloom SA, Clark P, Oakley CM, Cleland JG. Elevated plasma endothelin concentrations in heart failure; an effect of angiotensin II? Eur Heart J $1994 ; 15: 1634-1640$.

166. Tomoda H. Plasma endothelin-1 in acutio myocardial infarction with heart tailure. Am Heart J 1993;125:667-672.

167. Wei C, Lerman $A$, Rodeheffer $R$ J, McGregor $\mathrm{CGA}$ Brandt $\mathrm{AP}$, Wright $\mathrm{S}$, Heublein DM, Edwards WD, Burnett JC. Endothelin in human congestive heart fallure. Circulation 1994;89:1580-1586.

168. Pacher $R$, Berglerklein J, Globits $S$, Teufelsbauer $H$, Schuller $M$, Krauter $A$, Ogris $E$, Rodler $S$, Wutte $M$, Hartter $E$. Plasma big endothelin-1 concentrations in congestive heart failure patients with or without systemic hypertension. Asn J Car- 
diol 1993;71:1293-1299.

169. Omland T, Lie RT, Aakvaag A, Aarsland $T$. Dickstein K. Plasma endothelin determination as a prognostic indicator of 1 year mortality after acute myocardial infarction. Circulation 1994;89:15731579.

170. Pacher $R$, Stanek $B$, Hulsmann $M$, Koller-Strametz J, Berger R, Schuller $M$, Hartter $E_{r}$ Ogris $E$, Frey $B$, Heinz $G$. Maurer G. Prognostic impact of big endothelin-1 plasma concentrations compared with invasive hemodynamic evaluation in severe heart failure. $J \mathrm{Am}$ Coll Cardiol 1996;27:633-641.

171. Cody RJ, Haas GJ, Binkley PF, Capers Q. Kelley R. Plasma endothelin correlates with the extent of pulmonary hypertension in patients with chronic congestive heart failure. Circulation 1992; 85:504-509.

172. Tsutamoto T, Wada A, Maeda $Y$, Adachi $T$, Kinoshita $M$. Relation between endothelin-1 spillover in the lung and pulmonary vascular resistance in patients with chronic heart failure. I Am Coll Cardio/ 1994:23:1427-1433.

173. Lerman A, Kubo SH, Tschumperlin LK, Burnett JC Jr. Plasma endothelin concentrations in humans with end-stage heart failure and after heart transplantation. I Am Coll Cardiol 1992;20:849853.

174. Haas GJ, Wooding-Scott M, Binkley PF, Myerowitz PD, Kelley $R$, Cody RJ. Elfects of successful cardiac transplantation on plasma andothelin. Am J Cardiol 1993;71:237-240.

175. Kiowski $W$, Sutsch G, Hunziker $P$, Muller $P$, Kim $J$, Oechslin $E_{*}$ Schmitt $R$,

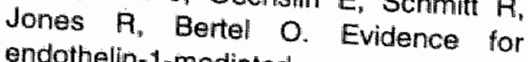
endothelin-1-mediated vasoconstriction in severe chronic heart failure. Lancet 1995;346:732-736.

176. Sakai S, Miyauchi T. Kobayashi M
Yamagushi I, Goto K, Sugishita Y. Inhibition of myocardial endothelin pathway improves long-term survival in heart failure. Nature 1996;384:353-355.

177. Furchgott RF. The discovery of endothelium-dependent relaxation. CircuJation 1993;87:V3-V8.

178. Busse A, Fleming I, Schini VB: Nitric oxide formation in the vascular wall: regulation and functional implications, in Koprowski $\mathrm{H}$, Maeda $\mathrm{H}$ (eds): The role of nitric oxide in psysiology and pathophysiology. Berlin, Springer-Verslag. 1995, pp. $7-18$.

179. Wang $Y$, Marsden PA. Nitric oxide synthases: biochemical and molecular regulation. Curr Opin Nephrol Hypertens 1995;4:12-22.

180. Radomski MW, Palmer RM, Moncada S. Glucocorticoids inhibit the expression of an inducible, but not the constitutive, nitric oxide synthase in vascular endothelial cells. Proc Nati Acad Soi U S A 1990; 87:10043-10047.

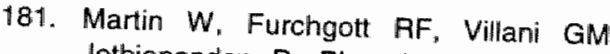
Jothianandan D. Phosphodiesterase inhibitors induce endothelium-dependent relaxation of rat and rabbit aorta by potentiating the effects of spontaneously released endothelium-derived relaxing factor. J Pharmacol Exp Ther 1986; 237:539-54.7.

182. Furchgott RF, Vanhoutte PM. Endothelium-derived relaxing and contracting factors. Faseb $d 1$ 1989;3:2007-2018.

183. Xie QW, Cho HJ, Calaycay J, Mumford RA, Swiderek KM, Lee TD, Ding A, Trosio $T$. Nathan $C$. Cloning and characterization of inducible nitric oxide synthase from mouse macrophages. Science 1992 ;256:225-228.

184. Nakayama I, Kawahara $Y$. Tsudda $T$, Okuda M, Yokoyama M. Angiotensin II inhibits cytokine-stimulated inducible nitric axide synthase expression in vascular 
smooth muscle cells. I Biol Chem 1994;269:11628-11633.

185. Sirsjo A, Soderkvist $P$, Sundqust $T_{\text {t }}$ Carlsson M, Ost M, Giddlof A. Different. induction mechanisms of mRNA for inducible nitric oxide synthase in rat smooth muscle cells in culture and in aortic strips. FEBS Lett 1994;338:191. 196.

186. Kolde M, Kawahara $Y$, Tsuda $T$, Nakayama I, Yokoyama M. Expression of nitric oxide synthase by cytokines in vascular smooth muscle cells. Hypertension $1994 ; 23: 145-148$.

187. Cho $H_{J}$, Xie QW, Calaycay $J$, Mumford RA, Swiderek KM. Lee TD, Nathan C. Calmodulin is a subumit of nitric oxide synthase from macrophages. I Exp Med 1992; 176:599-604.

188. Ribeiro $M O$, Antumes $E$, Denucci $G$, Lovisolo SM, Zatz $\mathrm{R}$, Chronic inhibition of nitric oxide synthesis - A new model of arterial hypertension. Hypertension $1992 ; 20: 298-303$

189. Johnson RA, Freeman RH. Sustained hypertension in the rat induced by chronic blockade of nitric oxide production. Am J Hypertens 1992;5:919-922.

190. Arnal JF, el-Amrani Al, Chatellier $\mathrm{G}$, Menard J, Michel JB. Cardiac weight in hypertension induced by nitric oxide syrithase blockade. Hypertension 1993" 2:380-387.

191. Toda N, Kitamura $Y$, Okamura T. Neural mechanism of hypertension by nitric oxide synthase inhibitor in dogs. Hypertension $1993 ; 21: 3-8$.

192. Fandall MD, Girfith TM. EDRF plays central role in collaterall flow after arterial occlusion in rabbit ear. Am J Physiol 1992 263:H752-H760.

193. Ramaciotti C, Sharkey A, McClellan G, Winegrad $S$. Endothelial cells regulate cardiac contractility. Proc Natl Acad Sci
US A 1992;89:4033-4036.

194. Brutsaert DL, Meulemans AL; Sipido KR. Sys SU. Effects of damaging the endocardial surface on the mechanical performance of isolated cardiac muscle. Circ Res 1988;62.358-366.

195. Balligand $\downarrow$, Ungureanu D, Kelly RA, Kobzik L. Pimental D, Michel T. Smith TW. Abnormal contractile function due to induction of nitric oxide synthesis in rat cardiac myocytes follows exposure 10 activated macrophage-conditioned medium. J Clin Invest 1993;1993:91.

196. Smith JA, Shah AM, Lewis MJ. Factors released from endocardium of the ferret and pig modulate myocardlal contraction. $J$ Physiol Lond 1991:439:1-14.

197. Finkel MS, Oddis CV, Jacob TD, Watkins SC, Hattler BG, Simmons RL. Negative inotropic effects of cytokines on the theart mediated by nitric oxide. Science $1992 * 257: 387-389$.

198. Weyrich $A S_{1}$ Ma $X L$, Buerke M, Murohara $T$, Armstead VE, Lefer AM, Nicolas JM Thomas AP, Lefer DJ, Vinten-Johansen J. Physiological concentrations of nitric oxide do not elicit an acute negative inotropic effect in unstimullated cardiac muscle. Circ Res 1994:75:692-700.

199. Hare JM, Loh $E$, Craeger MA, Colucc WS. Nitric Oxide inthibits the positive inotropic response to $\beta$-adrenergic stimulation in humans with left ventricular dysfunction. Circulation 1995;92:2198-2203.

200. Mlohan P, Brutsaert DL, Paulus WJ, Sys SU. Myocardial contractile responise to nitric oxide and cGMP. Circulation 1996; 93:1223-1229.

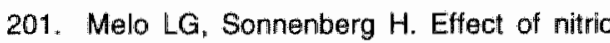
oxide inhibition on secretion of atrial natriuretic factor in isolated rat heart. $A m \mathcal{J}$ Physiol 1996:39:H306-H311.

202. Kato J, Misko TP, Currie MG. Induction of nitric oxide synthase regulates atriall natri- 
uretic peptide receptors in vascular smooth muscle cells. Eur $J$ col- Molec Pharm 1993:244:153-159.

203. Warner TD, de Nucci G, Vane JR. Endothelin is a vasodilator in the isolated perfused mesentery of the rat. Eur J Pharmacol 1989;159:325-326.

204. Goligorsky MS, Tsukahara H, Magazine $H_{\text {t }}$ Andersen TT, Malik AB, Bahou WF. Termination of endothelin signaling: role of nitric oxide. I Cell Physiol 1994; $158: 485-494$.

205. Habib F, Dutka D, Crossman D, Oakley CM, Cleland JG. Enhanched basal nitric oxide production in heart failure: another failed counter-regulatory vasodilator mechanism? Lancet 1994;344:371-372.

206. Haywood GA, Tsao PS, Vonderleyen HE, Mann MJ, Kelling PJ, Trindade PT, Lewis NP, Byrne CD, Rickenbacher PR, Bishopric NH, Cooke JP, McKenna WJ, Fowler MB. Expression of inducible nitric oxide synthase in human heart failure. Circulation 1996;93:1087-1094.

207. Habib FM, Springall DR, Davies GJ, Oakley CM, Yacoub MH, Polak JM. Tumour necrosis factor and inducible nitric oxide synthase in dilated cardiomyopathy. Lancet 1996;347:1151-1155.

208. de-Belder AJ, Radomski MW, Why HJ, Richardson PJ, Bucknall $\mathrm{CA}$, Salas $\mathrm{E}$ Martin JF, Moncada S. Nitric oxide synthase activities in human myocardium. Lancet 1993;341:84-85.

209. Thoenes M, Forstermann U, Tracey WR, Bleese NM, Nussler AK, Scholz H, Stein B. Expression of inducible nitric oxide synthase in failing and non-failing human heart. $\mathrm{J}$ Mol Cell Cardiol 1996 ; 28:165-169.

210. Patel KP, Zhang $K$, Zucker $\mathbb{H}$, Krukoff TL. Decreased gene expression of neuronal nitric oxide synthase in hypothalamus and brainstem of rats in heart failure. Brain Res 1996;734:109-115.
211. Smith $C_{y}$ Sun $D$, Hoegler $C$, Roth $B S$, Zhang $X$, Zhao $G$, $X u X$, Kobari $Y$, Pritchard $K$, Sessa WS, Hintze TH. Reduced gene expression of vascular endothelial NO synthase and cyclooxygenase- 1 in heart failure. Circ Res 1996;78:58-64.

212. Comini L, Bachetti T, Gaia G, Pasini E. Agnoletti L, Pepi $P$, Ceconi $C$, Curello $S_{\text {, }}$ Ferrari R. Aorta and skeletal muscle NO synthase expression in experimental heart failure. I Mol Cell Cardiol 1996; 28:2241-2248.

213. Dzau $V_{J}$, Ellison KE, Brody $T$, Ingelfinger J, Pratt RE. A comparative study of the distributions of renin and angiotensinogen messenger ribonucleic acids in rat and mouse tissues. Endocrinology 1987; 120:2334-2338.

214. Samani NJ. The renin-angiotensin system in cardiowascular physiology and disease: new insights from molecular studies. Quart J Med 1993;86:755-760.

215. Stock $P$, Liefeldt L, Paul M, Ganten D Local renin-angiotensin systems in cardiovascular tissues: localization and functional role. Cardiology 1995;86:2-8.

216. Dzau VJ. Local expression and pathophysiological role of renin-angiotensin in the blood vessels and heart. Basic Res Cardiol 1993;88:1-14.

217. Hirsch AT, Pinto YM, Schunkert $H$, Dzau VJ. Potential role of the tissue renin-angiotensin system in the pathophysiology of congestive heart failure. Am I Cardial $1990 ; 66: 22 \mathrm{D}-32 \mathrm{D}$

218. Dzau VJ. Vascular renin-angiotensin system and vascular protection. I Cardiovasc Pharmacol 1993;22 Suppl 5:S1-S9.

219. Sealey JE, Laragh JH: The reninangiotensin-aldosteron system for normal regulation of blood pressure and sodium and potassium homeostasis, in Laragh $\mathrm{JH}$, Brenner BM (eds): Hypertension. Pathoohysiology, diagnosis, and management. New York, Raven Press, 1990, 
vol 1, pp. 1287-1317.

220. Erdos EG, Skidgel RA. The angiotensin 1-converting enzyme. Lab lnvest 1987; 56:345-348.

221. Remes J. Neuroendocrine activation after myocardial infarction. Br Heart $J$ 1994:72:S65-S69.

222. Schelling $P$, Fischer $H$, Ganten $D$. Angiotensin and cell growth: a link to cardiovascular hypertrophy? J Hypertens 1991:9:3-15.

223. Geisterfer AA, Peach MJ, Owens GK. Angiotensin II induces hypertrophy not hyperplasia, of cultured rat aortic smooth muscle cells. Circ Res 1988; 62:749-756.

224. Daemen MJ, Lombardi $\mathrm{DM}_{*}$ Bosman FT, Schwartz SM. Angiotensin II induces smooth muscle cell proliferation in the normal and injured rat arterial wall. Circ Res 1991;68:450-456.

225. van Kleef EM, Fingerle $J$, Daemen MJAP. Angiotensin II induced progression of neointimall thickening in the balloon injured rat carotid artery is AT-1 receptor mediated. Arterioscl Thromb Vasc Biol 1996;16:857-863.

226. Morishita $R$, Gibbons $\mathrm{GH}_{\text {, Ellison } \mathrm{KE}}$ Lee $W$, Zhang $L N$, Yu $H$, Kaneda $Y_{\text {, }}$ Ogihara T, Dzaul VJ. Evidence for direct local effect of angiotensin in vascular hypertrophy - In vivo gene transfer of angiotensin converting enzyme. J Clin Invest 1994;94:978-984.

227. Griffin SA, Brown WC, MacPherson $F_{n}$ MCGrath JC, Wilson VG, Korsgaard $N_{\text {, }}$ Mulvany MJ, Lever AF. Angiotensin II causes vascular hypertrophy in part by a non-pressor mechanism. Hypertension 1991;17:626-635.

228. Simon G, Altman S. Subpressor angiotensin II is a bifunctional growth factor of vascular muscle in rats. $J$ Hypertens 1992;10:1165-11171.

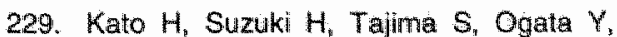
Tominaga T, Sato A, Saruta T. Angloten: $\sin 11$ stimulates collagen synthesis in cultured vascular smooth muscle cells. J Hypertens 1991:9:17-22.

230. Crawtord $D C_{\text {" }}$ Chobanian $A V$, Brecher $P$. Angiotensin II induces fibronectin expres: sion associated with cardiac fibrosis in the rat. Circ Res 1994:74:727-739.

231. Henegar JR, Brower GL, Kabour A, Jantcki JS. Catecholamine response to chrom nic ANG II infusion and its role in myocyte and coronary vascular damage. Am $J$ Physiol 1995;269:H1564-H1569.

232. Ogihara $T$, Nagano $M_{r}$ Higaki J, Kohara $\mathrm{K}$. Mikami $\mathrm{H}$. Persistent inhibition of the pressor and aldosterone responses to angiotensin-II by TCV-116 in normotensive subjects. I Cardiovasc Pharmacol $1995 ; 26: 490-494$

233. Ito $M_{*}$ Oliverio $M$, Mannon PJ, Best $C F$, Maeda $N_{\text {w }}$ Smithies $O$, Coffman TM. Regulation of blood pressure by the type $1 \mathrm{~A}$ angiotensin II receptor gene. Proc Natl Acad Sci U S A 1995;92:3521-3525.

234. Persson PB. Modulation of cardiovascular control mechanisms and their interaction. Physiol Rev 1996;76:193-244.

235. Faber JE, Brody MJ. Central nervous sys tem action of angiotensin during onset of renal hypertension in awake ralls. Am $J$ Physiol 1984;247: H349-H360.

236. Boke $T$, Malik KU. Enhancement by locally generated angiotensin II of release of the adrenergic transmitter in the isolated rat kidney. I Pharmacol Exp Ther 1983;226:900-907.

237. DiBona GF. Neural control of renal function: cardiavascular implications. Hypertension 1989;13:539-548.

238. Hilgers KF, Veelken R, Kreppner I, Ganten D, Luft FC, Geiger H, Mann JF. Vascular angiotensin and the sympathetic nervous system: do they interact? $A m$ I 


\section{Physiol 1994,267:H187+H194}

239. Kune fil. Chow KY, Mercer PF. Does enhanched sympathetic tone contribute to angiotensin II thypertension in rats? Eur J Phamacol 1990;104:109,118.

240. Van Kleef EM, Smits JFM, de Mey JFM, Cleutjens JPM, Lombardi DM, Schwartz SM, Daemen MJAP, al-Adrenoreceptor blockade reduces the angiotensin $\|$-induced vascullar smooth muscle cell DNA symthesis in the rat tharacic aorta and carotid arteny. Ciro Res 1992: $70 \cdot 1122-1127$.

241. van Klbef EM, Smits JFM, Schwartz SM, Daemen MJAP. Doxiazosin blocks the angiotensin $I I$-induced smooth muscle cell DNA synthesis in the media but not in the neointima of the rat carotid artery atter balloon injury. Cardiovasc fies 1996;31:324-330.

242. Stadeager $C_{*}$ Hesse $B$, Henriksen $O$, Bonde-Petersen F, Mehisen J, Rasmussen $S$. Influence of the renin-angiotensin system on human forearm blood flow. $\mathcal{I}$ Appl Physiol 1990;68:527-532.

243. Lyons $D$, Webster $J$, Benjamin N. Angiotensin II. Adrenergic sympathetic constrictor action in humans. Circulation $1995 ; 91: 1457-1460$.

244. Seidelin PH, Collier JG, Struthers AD, Webb DJ. Angiotensim It augments sympathetically mediated arteriolar constriction in men. Clin Sci 1991;81:261-266.

245. Nakamoto $H$, Suzuki $H$, Murakami $M_{\text {, }}$

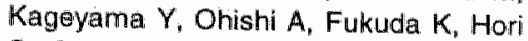
S. Saruta T. Effects of endothelin on systemic and renal haemodynamics and neuroendocrine hormones in conscious dogs. Chin Sci 1989;77:567-572.

246. Cahill PA, Redmond EM, Foster C, Sitzmann JV. Nitric oxide regulates angiolensin II receptors in vascular smooth muscle cells. Eur \& Pharmacol 1995 . 288:219-229.
247. Bumett JC, Granger JP, Opgenorth Tu. Effects of symthetic atrial natriuretic factor on renal function and renin release. $A m$ J Physiol 1984:247:F853-F866.

248. Matsukawa T, Mano T. Atrial natriuretic hormone inhibits angiotensin 11-stimulated sympathetic nerve activity in humans. Am $J$ Physiol 1996;40:R464.R471.

249. Cargill RI, Struthers D. Lipworth B. Comparative effects of atrial natriuretic peptide and brain natrumetic peptide on the aldosterone and pressor responses to angiotensin II in man. Chin Sor 1995; 88:81-86.

250. Anderson $J V$ Struthers AD, Payne NN, Slater JDH, Bloom SA. Atrial natriuretic peptide inhibits the aldosterone response to angiotensin II in mam. Clin Sci $1986 * 70: 507-512$.

251. Foikow B. Physiological aspects of primary hypertension. Physiol Rev 1982. $62: 347-504$.

252. McAlpine HM, Marton Jل, Leckie B, Rumley $A$, Gillen $G$, Dargie $H J$, Neuroendocrine activation after acute myocardial infarction. $\mathrm{Br}$ Heart $\mathrm{J} 1988 ; 60: 117-124$.

253. Dzau VJ, Colucci WS, Hollenberg NK, Williams $\mathrm{GH}$. Relation of the reninangiatensin-aldosteron system to cinical stale in congestive heart failure. Circulation $1981 ; 63: 645-651$.

254. Kubo SH, Clark M, Laragh $₫$ H, Borer JS, Cody RJ. Identification of normal neurohormonal activity in mild congestive heart failure and stimulating effect of upright posture and diuretics. Am I Cardiol 1987; 60:1322-1328.

255. Schunkert H, Ingelfinger JR, Hirsch AT, Tang $S$, Litwin SE. Talsness CE, Dzau VJ. Evidence for tissue-specific activation of renal angiotensinogen mRNA expression in chronic stable experimental heant failure. J Clin Invest 1992;90:1523-1529.

256. Huang $H$, Amal $\downarrow$, Llorens-Cortes $C$, 
Challah $M$, Alhenc-Gelas $F$, Corvol $P$, Michel JB. Discrepancy between plasma and lung angiotensin-converting enzyme activity in experimental heart failure. A novel aspect of endothelium dysfunction. Circ Res 1994;75:454-461.

257. Hodsman GP, Kohzuki $M$, Howes LG, Sumithran $E_{\text {„ }}$ Tsunoda $K$, Johnston $C l$. Neurohumoral responses to chronic myocardial infarction in rats. Circulation $1988 ; 78: 376-381$.

258. Hirsch AT, Talsness CE, Schunkert $H$, Paul M, Dxau VJ. Tissue-specitic activation of cardiac angiotensin converting enzyme in experimental heart failure. Circ Res 1991;69:475-482.

259. Pinto YG, de Smet BGJL, van Gilst WH, Scholtens E, Monnink S, de Graelf $H$, Wesseling $H$. Selective and time related activation of the cardic renin-angiotensin systern after experimental heart failure: relation to ventricular function and morphology. Cardiovasc Res 1993;27:19331938.

260. Yamagishi $H_{4}$ Kim $S$, Nishikimi T, Takeuchi $K$, Takeda $T$. Contribution of cardiac renin-angiotensin system to ventricular remodeling in myocardialinfarcted rats. I Mol Cell Cardiol 1993;25:1369-1380.

261. Michel $J B_{i}$ Lattion $A L$, Salzmann $J L$, Cerol ML, Philippe M. Camilleri JP, Corvoll P. Hormonal and cardiac effects of converting enzyme inhibition in rat myocardial infarction. Circ Res 1988;82: 1973-1984.

262. Schunkert $H$, Tang $S$, Litwin SE, Diamant $D$, Riegger $G$, Dzau VJ, Ingelfinger $J R$. Regulation of intrarenal and circulating renin-angiotensin systems in severe heart failure in the rat. Cardiovasc Res 1993;27:731-735.

263. Hu K, Gaudron P, Bahner U, Palkovits $M$, Ertl $G$. Changes in atrial natriuretic peptide in brain areas of rats with chronic myocardial infarction. Am J Physiol
$1996 ; 270: H 1312-4316$.

264. Timmermans PBMWM, Wong PC, Chiu AT, Herblin WF, Benfield P, Carini DJ, Lee RJ, Wrexler RR, Saye JAM, Smith RD. Angiotensin II receptors and angiotensin II receptor antagonists. Pharm Rev $1993 ; 45: 205-25 \pi$.

265. Sasaki $K$, Yamano $Y$, Bardhan $S$, Iwai $N$, Murray $J J$, Hasegawa $M_{0}$ Matsuda $Y_{\text {, }}$ Inagami $T$. Cloning and expression of a complementary DNA encoding a bovine adrenal angiotensin II type-1 receptor. Nature 1991;351:230-232.

266. Dzau VJ, Gibbons GH, Pratt RE. Molecular mechanisms of vascular renin-angiotensin system in myointimal hyperplasia. Hypertension 1991;18:11100-11105.

267. Dudley DT, Panek RL, Major TC, Lu GH, Bruns RS, Klinkefus BA, Hodges $J C$, Weishaar RE. Subclasses of angiotensin II binding sites and their functional signiffcance. Mol Pharm 1990;38:370-377.

268. Millan $M A$, Jacobowitz $D M$, Aguilera $G$, Catt KJ. Differential distribution of ATI and AT2 angiotensin II receptor subtypes in the rat brain during development. Proc Natl Acad Sci U S A 1991:88:11440. 11444.

269. Ichiki T, Labosky PA, Shiota $C_{\text {"Okuyama }}$ S, Imagawa I, Fogo A, Nilmura F, Ichikawa I. Hogan BLM, Inagami T. Effects on blood pressure and exploratory behaviour of mice lacking angiotensin II type 2 receptor. Nature 1995;377:748-750.

270. Hein L, Barsh GS, Pratt RE, Dzau VJ, Koblika BK. Behavioural and cardiovascular effects of angiotensin II type -2 receptor gene in mice. Nature 1995;377: 744-747.

271. Lo M, Liu KL, Lantelme P, Sassard J. Subtype 2 of angiotensin II receptors controls pressure-natriuresis in rats. J Clin Invest 1995;95:1394-1397.

272. Stoll $M$, Steckelings $M$, Paul $M$, Bottari 
SP, Metzger $\mathrm{A}$, Unger $\mathrm{T}$. The angioten$\sin$ AT2-receptor medialtes inhibition of cell proliferation in coronary endothellal cellig. J Chin invest 1995;05:651-657.

273. Tsuzuki S, Matoba T, Eguchi S lnagami T. Angiotensin II Type 2 receptor inhibits cell proliteration and activates yrosine phosphatase. Hypertension 1996;28: 916-918.

274. Yamada T. Horiuchi M, Dzau W.. Angiotensini II type 2 receptor mediaties programmed cell death. Proc Nall Acad Scj US A 1996;93:156-160.

275. Stoll $M$, Meffert S, Stroth U, Unger $T$. Growth or antigrowth: angiotensin and the endothelium. I Hypertens $1905 ; 13$ : $1529-1534$.

276. Griendling KK, Lassegue $B$, Alexander AW. Angiotensin receptors and their therapeutic implications. Annu Rev Pharmacol Toxicol 1996;36:281-306.

277. Marrero MB, Schieffer B, Paxton WG, Duff JL. Berk BC, Bernstein KE. The role of tyroshrie phosphorylation in angiotensin II-mediated intracellular signalling. Cardiovasc Res 1995;30:530-536.

278. Dulf JL, Marrero MB, Paxton WG, Schieffer B, Bernstein KE, Berk $B C$. Angiotensin II signal transduction and the mitogen-activated protein kinase patthway. Cardiovasc Res 1995;30:511. 517.

279. Schieffer B, Paxton WG, Marrero MB, Bernstein $K E$. Importance of tyrosine phosphorylation in angiotensin II type 1 raceptor signaling. Hypertension 1996 ; $27: 476-480$.

280. Zhang J, Pratt RE. The AT-2 receptor selectively associates with G-io2 and Gi-a3 in the rat fetus. Biol Chem 1996; $271: 15026-15033$.

281. Hayashida $W$, Horiuchi $M$, Dzau VJ Intracellular third loop domain of angio. tensin 11 Type-2 receptor. Role in medi- ating signal transduction and cellular function. J Biol Chem 1996,271:21985. 21992 .

282. Siragy HM, Carey RM. The subtype-2 (AT2) angiotensin receptor regullates renal cyclic guanosine $3^{2}, 5^{\prime}$ monophosphate and AT1 receptor-mediated prostaglandin e(2) production in conscious rats. J Clin Invest 1996;97:1978-1982.

283. Sechi LA, Griffin CA, Grady EF, Kalinyak $J E$, Schambelan M. Characterization of angiotensin II receptor subtypes in rat heart. Circ Res 1992;71:1482-1489.

284. Nio $Y$, Matsubara H, Murasawa S, Kanasaki M, Inada M. Regulation of gene transcription of angiotensin II receptor subtypes in myocardial infarction. $J \mathrm{Clin} / \mathrm{m}$ vest $1995 ; 95: 46-54$.

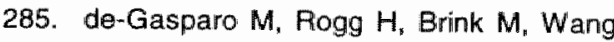
$L$, Whitebread $S_{n}$ Bullock $G$, Erne P. Angiotensin II receptor subtypes and cardiac function. Eur Heart J 1994;15 Suppl D:98-103.

286. Urata H, Healy B, Stewart RW, Bumpus FM. Husain A. Angiotensin II receptors in normal and failing human hearts, \& Clin Endocrinol Metab 1989;69:54-66.

287. Regitz-Zagrosek $V$, Friedel $\mathbb{N}$, Heymann A, Bauer P, NeuB M, Rolfs A, Steffen C. Hildebrandt A, Hetzer R, Fleck E. Regulation, chamber localization and subtype distibution of angiotensin $\|$ receptors in human hearts. Circulation 1995;91:1461. 1471.

288. Viswanathan $M$. Stromberg $C$, Seltzer $A$. Saavedra JM. Balloon angioplasty enhances the expression of angiotensin-ll AT 1 receptors in neointima of rat aorta. $J$ Clin invest 1992;90:1707-1712.

289. Viswanathan $M$, Tsutsumi $K_{1}$ Correa FMA, Saavedira JM. Changes in expres sion of angiotensin receptor subtypes in the rat aorta during dewelopment. Biochem Biophys Res Commun 1991;179: 1361-1367. 
290. Rogg $H$, de Gasparo $M$, Graedel $E$,

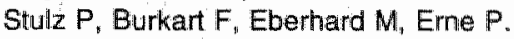
Angiotensin Il-receptor subtypes in human atria and evidence for alterations in patients with cardiac dysfunction. Eur Heart I 1996;17:1112-1120.

291. Lopez JJ, Lorell $B H$, Ingelfinger JR, Weinberg EO, Schunkert $H$, Diamant $D$. Tang SS. Distribution and function of cardiac angiotensin AT1- and AT2-receptor subtypes in hypertrophied rat hearts. Am U Physiol 1994;267:H844$\mathrm{H} 852$.

292. Pieruzzi F, Abassi ZA, Keiser HA. Expression of renin-angiotensin system components in the heart, kidneys, and lungs of rats with experimental heart failure. Circulation 1995;92:3105-3112.

293. Lefroy DC, Wharton J, Crake $T$, Knock $G A$, Rutherford RAD, Suzuki T, Morgan $K$, Polak JM, Poole-Wilson PA. Regional changes in angiotensin III receptor density after myocardial infarction. I Mol Cell Cardiol 1996;28:429-440.

294. Sun $Y$, Weber KT. Anglotensin II receptor binding following myocardial infarction in the rat. Cardiovasc Res 1994;28: 1623-1628.

295. Makino $N$, Hata $T$, Sugano $M$, Dixon IMC, Yanaga T. Regression of hypertrophy after myocardial infarction is produced by the chronic blockade of angiotensin type 1 receptor in rats. $J \mathrm{Mol}$ Cell Cardiol 1996;28:507-517.

296. Unger $T$, Ganten $D$, Lang RE, SchoIkens BA. Persistent tissue converting enzyme inhibition following chronic treatment with Hoe498 and MK421 in spontaneously hypertensive rats. $J$ Cardiovasc Pharmacol 198:5;7:36-41.

297. Naftilan AJ, Zuo WM. Inglefinger $J$, Ryan $T J J r$, Pratt RE, Dzau VJl. Localization and differential regulation of angiotensinogen mRNA expression in the vessel wall. J Clin Invest 1991; 87:1300-1311.
298. Jandeleit K, Jackson B, Perich R, Paxton D. Johnston C. Angiotensin-converting enzyme in macro- and microvessels of the rat. Clin Exp Pharmacol Physiol 1991; $18: 353-356$.

299. Campbell DJ, Habener JF. Anglow tensinogen gene is expressed and differentially regulated in multiple tissues of the rat. J Clin Invest 1986;78:31-39.

300. Cockcroft JR, O'Kane KP, Webb DJ. Tissue angiotensin generation and regula. tion of vascular tone. Pharmacol Ther 1995;65:193-213.

301. Weishaar RE, Panek RL, Major TC, Simmerman J Rapundalo ST, Taylor DG $\mathrm{Jr}$. Evidence for a functional tissue reninangiotensin system in the rat mesenteric vasculature and its involvement in regulating blood pressure. I Pharmacol Exp Ther 1991;256:568-574.

302. Oliver JA, Sciacca RR. Local generation of angiotensin II as a mechanism of regulation of peripheral vascular tone in the rat. J Clin Invest 1984;74:1247-1251.

303. Mizuno $K$, Tani $M$, Niimura $S$, Sanada $H$, Haga $H$, Hashimoto $S$, Watanabe $H_{\text {, }}$ Ohtsuki M, Fukuchi S. Losartan, a specific angiotensin-ll receptor antagonist, increases angiotensin-I and angiotensin-II rellease from isolated rat hind legs - evidence for locally regulated renin-angiotensin system in vascular tissue. Life Sci 1992;50:PL209-PL214.

304. Mizuno $K$, Nakamaru $M$, Higashimori $K$, Inagami $T$. Local generation and release of angiotensin 11 in peripheral vascular tissue. Hypertension 1988:11:223-229.

305. Webb DJ, Collier JG, Seidelin PH, Struthers $A D$. Regulation of regional vascular tone: the role of angiotensin conversion in human forearm resistance vessels. I Hypertens 1988;6:S57-S59.

306. Vicaut $E$, Hou X. Arteriolar constriction and local renin-angiotensin system in rat microcirculation. Hypertension 1993:21: 


\section{$491-497$.}

307. Pfeffer JM, Fischer TA, Piffer MA. Angiotensin-converting enzyme inhibition and ventricular remodeling after myocardial infarction. Annu Rev Physiol 1995;57:805-826.

308. Pteffer MA, Lamas $G A$, Vaughan $D E$, Parisi AF, Braunwald $E$. Effect of captopril on progressive ventricular dilatation after anterior myocardial infarction. NEngl J Med 1988;319:80-86.

309. Dzau VJ. Tissue renin-angiotensin system in myocardial hypertrophy and failure. Arch Intarn Med 1993;153:937-942.

310. Studer $\mathrm{R}$, Reinecke $\mathrm{H}$, Muller $\mathrm{B}, \mathrm{Holtz} \mathrm{J}$, Just $H$, Drexler $H$. Increased angiotensin-I converting enzyme expression in the failing human heart. Quantification by competitive RNA polymerase chain reaction. J Clin Invest 1994;94:301-310.

311. Passier RC, Smits JF, Verluyten MJ, Studer R, Drexler H, Daemen MJ. Activation of angiotensin-converting enzyme expression in infarct zone following myocardial infarction. Am \& Physiol 1995;269:H1268-H1276.

312. Passier RCJJ, Smits JFM, Verluyten MJA, Daemen MJAP. Expression of renin and angiotensinogen in rat heart after myocardial infarction. Am J Physiol 1996;271:H1040-H1048.

313. Yamori $Y$, Mano $M$, Nara $Y$, Horie $A$. Catecholamine-induced polyploidization in vascular smooth muscle cells. Circu. lation 1987;75:192-195.

314. deBlois D, Schwartz SM, van Kleef EM, Su JE, Griffin KA, Bidani AK, Daemen MJAP, Lombardi DM. Chronic $a \%$ adrenoreceptor stimulation increases DNA synthesis in rat arterial wall. Modulation of responsiveness after wascular injury. Arteriosel Thromb Vasc Biol 1996;16:1122-1129.

315. Chua BHL, Krebs CJ, Chua CC, Diglio
CA. Endothelin stimulates protein synthesis in smooth muscle cells. Am J Physiol 1992;262:E412-E416.

316. Ito $H$, Hirata $Y_{\text {, Hiroe } M}$, Tsujino $M$, Adachi $S$, Takamoto $T$, Nitta $M_{s}$ Taniguchi $K_{*}$ Marumo F. Endothelin-1 induces hypertrophy with enhanced expression of muscle-specific genes in cultured neonatal rat cardiomyocytes. Circ Res 1991; 69:209-215.

317. Battistini $B$, Chailler $P$, D'Orleans-Juste $P$, Briere $N$, Sirois $P$. Growth regulatory properties of endothelins. Peptides 1993; 14:385-399.

318. Nunokawa $Y$, Tanaka $S$ Interferongamma inhibits proliferation of rat vascular smooth muscle cells by nitric oxide generation. Biochem Biophys Res Commun 1992;188:409-415.

319. Guo JP, Milhoan KA, Tuan RS, Lefer AM. Beneficial effect of SPM-5185, a cysteine-containing nitric oxide donor, in rat carotid artery intimal injury. Circ Res 1994;75:77-84

320. Scott-Burden T, Schini VB, Elizondo $E$, Junquero DC, Vanhoutte PM. Plateletderived growth factor suppresses and fibroblast growth factor enhances cytokine-induced production of nitric oxide by cuitured smooth muscle cells - Esfects on cell proliferation. Circ Res 1992; 71:1088-1100.

321. Scott-Burden T, Vanhoutte PM. The endothelium as a regulator of vascular smooth muscle proliferation. Circulation $1993 ; 87: 51-55$.

322. Itoh $H$, Pratt RE, Dzau VJ. Atrial Natriuretic Polypeptide inhibits hypertrophy of vascular smooth muscle cells. $J$ Clin $\mathrm{ln}$ vest 1990;86:1690-1697.

323. Itoh $H$, Pratt RE, Ohno M, Dzau VJ. Atrial natriuretic polypeptide as a novel antigrowth factor of endothelial cells. Hypertension 1992;19:758-761. 
324. Cahill PA, Hassid A. Clearance neceptor-binding atrial natriuretic peptides inhibit mitogenesis and proliferation of rall aortic smooth muscle cells. Biochem Biophys Res Commun 1991; 179:1606-1613.

325. Mourlon-le Grand MC, Poitevin $P$, Benessiano J, Duriez $M_{1}$, Michel JB, Levy BI. Elfect of a nonhypotensive long-term infusion of ANP on the mechanical and structural properties of the anterial wall in Wistar-Kyoto and Spontaneously Hypertensive Rats. Arteriosch Thromb Vasc Biol 1993;13:640-650.

326. Komatsu $Y$, Itoh $\mathbb{H}$, Suga $S$, Ogawa $Y$, Hama N, Kishimoto I, Nakagawa $O$, Igaki T, Doi K, Yoshimasa T, Nakao K. Regulation of endothelial production of c-type natriuretic peptide in coculture with vascular smooth muscle cells . Role of the vascular natriuretic pepticie system in vascular growth inhibition. Circ Res 1996;78:606-614.

327. Mulvany MJ. Resistance vessel structure and the pathogenesis of hypertension. J Hypertens 1993;11:S7-S12.

328. Zelis R, Delea CS, Coleman HN, Mason DT. Arterial sodium content in experimental heart failure. Circ Res 1970; 41:213-216.

329. Sinoway L, Minotti J, Musch T, Goldner D, Davis D, Leaman D, Zelis R. Enhan* ced metabolic vasodilation secondary to diuretic therapy in decompensated congestive heart failure secondary to coronary artery disease. Am I Cardiol 1987;60:107-111.

330. Langhurst $\mathrm{J}$, Capone RJ, Zelis R. Evaluation of skeletal muscle capillary basement membrame thickness in congestive heart failure. Chest 1975;67:195198.

331. Wroblewski $H$, Kastrup J, Norgaard $T$, Mortensen S, Hauso S. Evidence of increased microvascular resistance and arterialar hyalinosis in skin in congestive heart failure secondary to idiopathic dilated cardiomyopathy. Am J Cardiol 1992; 69:769-774.

332. Wroblewski $H_{8}$ Norgaard $T$, Haunso $S$, Kastrup J. Microvascular distensibility in two different vascular beds in idiopathic dilated cardiomyopathy. Am J Physiol 1995;38:H1973-H1980.

333. Lindsay DC, Anand IS, Bennett JG, Pepper JR, Yacoub MH, Rothery SM, Severs NJ, Poole-Wilson PA. Ultrastructural analysis of skeletal muscle. Microvascular dimensions and basement membrane thickness in chronic heart fallure. Eur Heart J 1994;15:1470-1476.

334. Schieffer B, Wollert KC, Berchtold $M$, Saal K, Schieffer E, Hornig B, Tiede UN, Drexler $H$. Development and prevention of skeletal muscle structural alterations after experimental myocardial infarction. Am J Physiol 1995;269:H1507-H1513.

335. Mulder $P$, Devaux $B$, el-Fertak L, Compagnon $P$, Richard $V$, Henry JP, Scalbert $E$, Desche $P$, Mace $B$, Thuillez C. Vascular and myocardial protective effects of converting enzyme inhibition in experimental heart failure. Am J Cardiol 1995;76:28E-33E.

336. Mulder P, Elfertak L, Richard V, Compagnon $P$, Devaux $B$, Henry JP, Scalbert $E$, Desche $\mathrm{P}$, Mace B, Thuillez C. Peripheral arter structure and endothelial function in heart failure: effect of $\mathrm{ACE}$ inhibition. Am J Physiol 1996;40:H469:H477. 


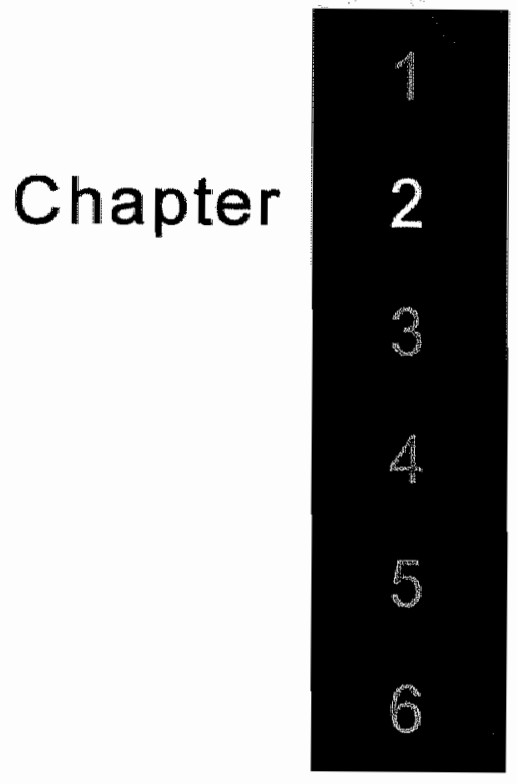

Peripheral Vascular Alterations during Experimental Heart Failure in the Rat. Do They Exist?

Sylvia Heeneman, Peter Leenders, Petra Aarts, Jan Willem Arends, Jos Smits, Mat Daemen

Arterioscler. Thromb. Vasc. Biol. 1995; 15: 15031511 
Background: Structural changes of the peripheral vascular component as seen during hypertension and atherosclerosis have been suggested during heart failure but have never been reported. Therefore, we studied possible structural alterations in the peripheral vasculature in an experimental model of heart failure. induced by ligation of the lett coronary artery in rats.

Methods and results: Both conduit and resistance type arteries were excised at $1,3,5$ and 12 weeks after induction of a myocardial infarction or sham surgery. Vessel dimensions (medial cross-sectional area, internal and external diameter and media-to-lumen ratios) as well as medial collagen and elastin volume fractions were measured by computerized morphometry. The hydroxyproline assay was used to determine collagen and elastin content biochemically. In separate groups of rats, peripheral tissue flows were measured using radicactive microspheres 5 and 12 weeks after myocardial infarction. To evaluate the effects of the degree of heart failure, rats of the 12 weeks group $(n=10)$ were subdivided in subgroups of moderate $(<45 \%$ infarct size) and large $(>45 \%$ infarct size) infarction. At all time points, body weights of sham-operated and myocardial infarcted (MI) rats were comparable. Lung weights of MI rats were increased proportional to infarct size. No major changes in vessel

\begin{abstract}
dimensions were seen at earlier time points. 12 Weeks after coronary artery ligation, significantly smaller medial cross-sectional areas were obsenved in several large conduit arteries as the thoracic aorta, carotid artery and superior mesenteric artery. These changes coincided with reductions in both internal and external diameters. In contrast, internal and external diameters of mesenteric and pulmonary resistance arteries were increased after 12 weeks of coronary artery ligation. Collagen and elastin volume fractions of large conduit anteries were comparable in both sham-operated and $M I$ rats during the entire experimental period. This latter observation was confirmed by the results of the hydroxyproline assay, which showed no differences in collagen and elastin content. In general, no major changes could be observed in absolute blood llow to peripheral tissues measured in resting conditions, at 5 and 12 weeks after coronary artery ligation.

Conclusions. The data indicate that myocardial infarction induces diverse adaptive changes in peripheral arteries. Medial cross-sectional areas, internal and external diameters of large conduit arteries of $\mathrm{MI}$ rats are smaller 12 weeks after the operation compared to shamoperated rats. These parameters show a tendency to increase in resistance type arteries.
\end{abstract}




\section{Introduction}

Changes in structure of the vascular wall have received ample attention in hypertension research. Increases in wall thickness have been reported both in large conduit arteries and resistance arterioles (reviewed in 1 and 2). This increase in wall thickness is the result of hypertrophy (in large vessels) or hyperplasia (in small vessels), as well as changes in extracellular matrix content. Both absolute collagen and elastin contents increase (3), without a change in relative volume fractions, indicating little change in the composition of the vascular wall (4). Structural changes of the vessel wall are also seen in other cardiovascular diseases such as atherosclerosis (5) and restenosis after balloon angioplasty (6). The magnitude and role of possible structural changes in another cardiovascular disease, heart failure, are unknown.

Functional peripheral vascular alterations have been reported both in patients and in animal models for heart failure and consist of an increased resistance dule to excessive vasoconstriction $(7,8)$. Maximal vasodilator capacity of various peripheral vascular beds is decreased $(9,10)$, probably caused by increased vascular stiffness, due to increased arterial sodium content (11). Distensibility of the aorta is also markedly reduced in patients with coronary artery disease (12). These functional vascular changes are thought to be partly related to the observed reduction in blood flow to peripheral tissues in rest and during exercise $(13,14)$.

Analogous to what is seen during hypertension, structural remodeling has been suggested as a possible mechanism for the above described changes in vascular resistance and distensibility during heart failure (reviewed in 15 and 16). However, there are, to our knowledge, no studies documenting such structural changes. Also, data on the time-course of possible structural changes in the vasculature during heart failure are lacking.

In this study we determined possible structural vascular alterations in experimental heart failure in the rat produced by coronary artery ligation. At specified times, several large conduit and resistance arteries were excised and vessel dimensions (including medial cross-sectional areas, internal and external diameters and media-to-lumen ratios) and collagen and elastin volume fractions were measured using histological staining methods and computerized morphometry. The hydroxyproline assay was used to determine collagen and elastin content biochemically. This study provides evidence for structural alterations of peripheral arteries in an experimental model of heart failure, which were, however, only present at the later time points examined and showed a heterogenous pattern. While the medial cross-sectional area and internal and external diameters of several large conduit vessels were smaller in MI rats, these parameters showed at least a tendency to increase in 2 resistance type arteries. There were no major quantitative changes in the extracellular matrix within the experimental time span. 


\section{Materials and Methods}

\section{Animals}

Male Wistar rats (290-320 g, Winkelmann, Borchen, Germany) were housed under standard conditions and fed standard rat chow (RMH-TM, Hope Farms, Woerden, The Netherlands) and water ad libitum. The experiments were performed in accordance with local institutional guidelines.

\section{Coronary artery ligation}

Myocardial infarction (MI) was induced by ligation of the left anterior descending coronary artery (LAD) according to the method of Fishbein (17) as described in detail previously (18). After intraperitoneal induction of anesthesia with sodium pentobarbital $(60 \mathrm{mg} / \mathrm{kg})$, positive pressure respiration was started through an endotracheal tube. The thorax was opened in the fourth left intercostal space and the LAD was occluded near the origin of the pulmonary artery by a 6-0 silk ligature. The thorax was closed in layers. In the sham-procedure a superficial suture was placed in the epicardium of the left ventricle, near the LAD. All rats received post-operative analgesics $10.3 \mathrm{mg} / \mathrm{ml}$ Temgesic, $250 \mu \mathrm{l}$ twice subcutaneously, Reckitt \& Colman Products Ltd, Kingston-upon-Hill, UK).

\section{Experimental protocol I: Structural changes in the vascular wall after coronary artery ligation}

Myocardial infarction was induced at 1 week $(n=7))$, 3 weeks $(n=8), 5$ weeks $(n=7)$ and 12 weeks $(n=10)$ before euthanization. At all time intervals, sham-operated rats served as controls ( 1 week $(n=6), 3$ weeks $(n=7), 5$ weeks $(n=7)$ and 12 weeks $(n=9))$.

\section{Tissue processing}

The rats were euthanized in ether anesthesia. The heart was arrested in diastole, by injecting $1-2 \mathrm{ml} \mathrm{CaCl}_{2}(0.1 \mathrm{M})$ into the inferior caval vein. The rats were perfused with Phosphate Buffered Saline (PBS), followed by perfusion with $5 \%$ phosphate buffered formalin (10 min each) at a pressure of $100 \mathrm{mmHg}$, via a catheter in the right carotid artery. To ensure maximal vasodilation, nitroprusside (1 $\mathrm{mg} / \mathrm{ml}$, Sigma, St Louis, MO, USA) was added to both perfusion solutions.

Vessel segments $(2-3 \mathrm{~mm})$ were obtained using anatomic landmarks. A vessel segment of the thoracic aorta was sampled between the first and second intercostal artery, the left carotid artery was sampled $0.5 \mathrm{~cm}$ cranial from the aortic arch, the abdominal aorta from the right iliolumbar artery to the bifurcation, the superior mesenteric artery from its origin at the aorta to its first branching point, the right renal artery from the suprarenal artery to its bifurcation at the hilus of the kidney and the right iliac artery from its origin at the bifurcation of the abdominal aorta to its bifurcation of the femoral arteries. Three mesenteric resistance arteries draining the jejunum were excised. Also, the right lung was 
excised to study the pulmonary resistance arteries.

After excision of the heart and removal of the atria, the ventricles were blotted dry and weighed. For determination of the wet/dry weight ratio, the apex was removed and weight separately. Apex dry weight was determined after freeze drying. The percentage water in the heart (apex) was calculated as $100^{*}$ (wet weight-dry weight)/wet weight. Lungs were also excised and weighed. All tissues were fixed overnight in $10 \%$ phosphate buffered formalin. Fixed tissues were processed and embedded in paraplast via routine histological procedures.

\section{Morphometric measurements.}

For elastin, rehydrated $4 \mu \mathrm{m}$ sections were incubated for $30 \mathrm{~min}$ in Lawson's solution (Klinipath, Zevenaar, The Netherlands), differentiated in $70 \%$ alcohol, dehydrated and mounted with Entellan. For collagen, rehydrated $4 \mu \mathrm{m}$ sections were incubated for $5 \mathrm{~min}$ with $0.2 \%$ (wt/vol) aqueous phosphomolybdic acid (19) and then incubated for $90 \mathrm{~min}$ with $0.1 \%$ Sirius Red F3BA (C.1. 35780, Polysciences, Northampton, $(\mathrm{KK}$ ) in saturated aqueous picric acid, washed for 2 min with $0.01 \mathrm{~N} \mathrm{HCl}$, dehydrated and mounted with Entellan (Merck, Darmstadt, F.R.G). Volume fractions of collagen and elastin of the media of large conduit arteries were evaluated with a computerized morphometric system (Quantimet 570, Leica, Cambridge, U.K.). Approximately 6 fields of the medial area (defined as the area between internal and external elastica laminae) of 2 to 3 cross sections of each vessel were analyzed using a $400 x$ magnification and the percentage of total tissue surface occupied by collagen or elastin was calculated. Intra- and interobserver variations of this method are less then $5 \%$ for the large conduit arteries (data not shown). The analyses were performed in a blinded fashion by three experienced investigators. Lawson's stained sections were also used to measure the medial cross-sectional areas, the internal and external diameters and media to lumen ratios (defined as the ratio of medial area and lumen area times* $100 \%$ ). Infarct size was determined on AZAN stained sections $(4 \mu \mathrm{m})$ of the heart using the same morphometric system. Infarct size was expressed in percent of left ventricular circumference (17). Rats with an infarct size less than $20 \%$ were excluded from all the studies described in this thesis, as previous hemodynamic studies in our laboratory indicated that these rats exhibited no signs of cardiac failure (20).

\section{Experimental protocol II: Biochemical changes in extracellular matrix of the} vascular wall 12 weeks after coronary artery ligation.

In a second group of 12 weeks $M I(n=7)$ and sham ( $n=9)$ rats, total collagen and elastin concentrations were determined biochemically using the hydroxyproline assay (21). Rats were euthanized in ether anesthesia. Large segments of conduit vessels were excised, again using anatomic landmarks. A segment of the thoracic aorta was sampled from the first to the eight intercostal artery. Both carotid arteries were taken from their origin at the aortic arch to the bifurcation in the 
internal and external carotid branches. A $2-\mathrm{cm}$ segment of the superior mesenteric artery was taken from its origin at the aorta. Both renal arteries were excised from their origin at the aorta to the bifurcation at the kidney. Finally, a 2 $\mathrm{cm}$ segment of the abdominal aorta was taken out.

The vessels were washed free of blood and cleared of adhering tissues. Using fine forceps, the medial layer of the thoracic aorta, the abdominal aorta and both carotid arteries was carefully separated from the adventitial layer. The renal arteries and the mesenteric artery :vere analyzed intact. Vessel segments of 2-3 rats were pooled for subsequent analyses.

Pooled vessel were lyophilized and weighed, $1.0 \mathrm{ml} / 4 \mathrm{mg}$ dry weight of hot $0.01 \mathrm{M}$ phosphate buffer containing 1.0\% sodium dodecyl sulphate (SDS), was added and the mixture was boiled for $15 \mathrm{~min}$, followed by overnight extraction at $20^{\circ} \mathrm{C}$ in the same buffer. The SDS extract was dialyzed against distilled water and lyophilized. Separation of elastin and collagen exploits the fact that elastin contains no methionine residues and thus resist digestion by $\mathrm{CNBr}$ (22). The residue after SDS extraction was digested with cyanogen bromide (CNBr, 50 $\mathrm{mg} / \mathrm{ml}$ in $70 \%$ formic acid) at $20^{\circ} \mathrm{C}$ for 24 hours. The $\mathrm{CNBr}$ extract, which contains collagen and other solubilized proteins was lyophilized. Insoluble residues remaining after CNBr extraction of the tissues were taken as elastin, lyophilized and weighed.

The amount of tissue elastin and collagen were measured by quantification of the amount of hydroxyproline in the CNBr residue (elastin) and the SDS extracts and $\mathrm{CNBr}$ extracts (total collagen) (21). All separate lyophilized fractions were hydrolyzed in $200 \mu \| 6 \mathrm{M} \mathrm{HCl}$ for 16 hours at $105^{\circ} \mathrm{C}$. The samples were dried under vacuum and reconstituted in 200 $\mu$ l double distilled water. 5-100 $\mu \mathrm{l}$ of each sample was taken and the volume was adjusted to $100 \mu \mathrm{l}$ with distilled water. Subsequently, $300 \mu$ of acetate-citrate-isopropanal buffer and $100 \mu$ l oxidant solution ( $84.5 \mathrm{mg}$ chloramine $\mathrm{T} / \mathrm{ml}$ ) was added and incubated during $5 \mathrm{~min}$ at 25 ${ }^{\circ} \mathrm{C}$. Finally, $1.3 \mathrm{ml} 3.5 \mathrm{M} \mathrm{p}$-dimethylamino-benzaldehyde in $72 \%$ perchloric acid was added and incubated during $30 \mathrm{~min}$ at $65^{\circ} \mathrm{C}$. Oxidation of hydroxyproline results in the formation of a pyrrole, which reacts with $p$ dimethylaminobenzaldehyde to form a colored compound. Absorbance was measured at $558 \mathrm{~nm}$ (Ultrospec III, Pharmacia Biotech, Brussels, Belgium). Calculation was performed using a calibration curve. Results are expressed as $\mu \mathrm{g}$ hydroxyproline/ $\mathrm{mg}$ dry weight for both elastin and collagen fractions. Finally, DNA concentrations in these segments were determined using the Hoechst assay.

\section{Experimental protocol III: Regional blood flow measurements 5 and 12 weeks after coronary artery ligation}

In a third group consisting of 5 and 12 weeks $M I(n=11$ and $n=11$ respectively) or sham rats ( $n=9$ and $n=7$ respectively), radioactive microspheres $\left(S n^{113}, 15 \pm 5 \mu \mathrm{m}\right.$ in diameter, Dupont, NEN products, Boston, MA) were used to measure regional 
Table 2.1 Characteristics of experimental groups at different time points after coronary artery ligation or sham surgery.

\begin{tabular}{|c|c|c|c|c|c|}
\hline & & 1 Week & 3 Weeks & 5 Weeks & 12 Woeks \\
\hline BW (g) & $\begin{array}{l}\text { sham } \\
\text { MI }^{\text {MI-MOD }} \\
\text { MI-LARGE }\end{array}$ & $\begin{array}{l}312 \pm 4(n=6) \\
306 \pm 10 \quad(n=7)\end{array}$ & $\begin{array}{l}361 \pm 8(n=7) \\
343 \pm 7(n=8)\end{array}$ & $\begin{array}{l}351 \pm 10(n=7) \\
369 \pm 11(n=7)\end{array}$ & $\begin{array}{l}459 \pm 12(n-9) \\
443 \pm 11(n=10) \\
460 \pm 11(n=5) \\
427 \pm 19(n=5)\end{array}$ \\
\hline $\mathrm{HW}(\mathrm{g})$ & $\begin{array}{l}\text { sham } \\
\text { MI" } \\
\text { MI-MOD } \\
\text { MI-LARGE }\end{array}$ & $\begin{array}{l}0.99 \pm 0.03 \\
0.92 \pm 0.04\end{array}$ & $\begin{array}{l}1.15 \pm 0.05 \\
1.08 \pm 0.04\end{array}$ & $\begin{array}{l}1.06 \pm 0.09 \\
1.20 \pm 0.03^{*}\end{array}$ & $\begin{array}{l}1.30 \pm 0.06 \\
1.47 \pm 0.04 \\
1.43 \pm 0.04 \\
1.5 \pm 0.07+\end{array}$ \\
\hline $\operatorname{LW}(g)$ & $\begin{array}{l}\text { sham } \\
\text { MI" } \\
\text { MI-MOD } \\
\text { MI-LARGE }\end{array}$ & $\begin{array}{l}1.45 \pm 0.04 \\
1.83 \pm 0.15^{*}\end{array}$ & $\begin{array}{l}1.51 \pm 0.17 \\
2.31 \pm 0.32^{*}\end{array}$ & $\begin{array}{l}1.75 \pm 0.18 \\
2.79 \pm 0.42^{*}\end{array}$ & $\begin{array}{l}1.70=0.07 \\
3.20 \pm 0.33^{*} \\
2.98 \pm 0.60 \dagger \\
3.4 \pm 0.38 \neq\end{array}$ \\
\hline $\begin{array}{l}\text { HW/BW } \\
\text { ratio } \\
(\mathrm{g} / \mathrm{kg})\end{array}$ & $\begin{array}{l}\text { sham } \\
\text { MI } \\
\text { MI-MOD } \\
\text { MI-LARGE }\end{array}$ & $\begin{array}{l}3.16 \pm 0.06 \\
3.01 \pm 0.08\end{array}$ & $\begin{array}{l}3.18 \pm 0.12 \\
3.15 \pm 0.09\end{array}$ & $\begin{array}{l}3.00 \pm 0.21 \\
3.27 \pm 0.12\end{array}$ & $\begin{array}{l}2.84 \pm 0.10 \\
3.33 \pm 0.14 \\
3.13 \pm 0.09 t \\
3.54 \pm 0.13+\end{array}$ \\
\hline $\begin{array}{l}\text { Infarct } \\
\text { size }(\%)\end{array}$ & $\begin{array}{l}\text { MI } \\
\text { MI-MOD } \\
\text { MI-LARGE }\end{array}$ & $41 \pm 4$ & $37 \pm 3$ & $37 \pm 4$ & $\begin{array}{l}39 \pm 4 \\
30 \pm 2 \\
49 \pm 4 \S\end{array}$ \\
\hline
\end{tabular}

Data are expressed as mean \pm sem. $B W=B$ ody weight, $H W=$ Heart weight, $L W=L u n g$ weight, MI-MOD=Moderate MI, MI-LARGE=Large MI. $\square$ : NOTE:MI 12 weeks is the combined data of MI-MOD and MI-LARGE. Statistical analysis: Individual group comparison by Mann-Whitney ${ }^{*} p<0.05$ sham versus MI, $\dagger p<0.05$ sham versus $M I-M O D$, $\ddagger p<0.05$ sham versus MI-LARGE, $\S p<0.05$ MI-MOD versus MI-LARGE. Effects in time by ANOVA: \#p<0.05.

blood flow according to the reference sample technique, adapted for use in the rat (23). Microspheres were suspended in saline, $0.01 \%$ Tween 80 and thoroughly mixed and agitated by sonification before each injection to prevent clumping.

\section{Instrumentation}

Under ether anaesthesia "polyethylene catheters were placed into the left ventricle (through the right carotid artery, PE50) and into the tail artery (PE10). The catheter for the left ventricle catheter was connected to a pressure transducer (Honeywell microswitch, Dépex, De Bilt Netherlands). Placement of the left ventricular catheter was verified by the change in pressure waveform upon entering the ventricle. Both catheters were exteriorized in the neck. After closure of all incisions, rats were given a minimum of 3 hours to recover from surgery. 

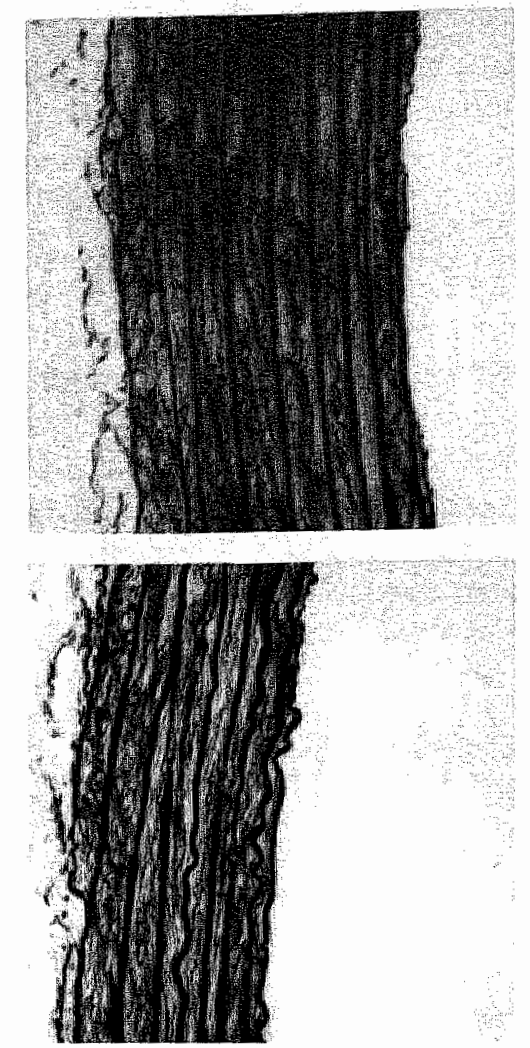

Figure 2.1 Example of lawson stained cross-sections of the thoracic aorta of a shamoperated rat (top panel) and a $\mathrm{Ml}$ rat (bottom panel) 12 weeks after the operation. Note the difference in medial thickness (magnification $400 \mathrm{x}$ )

ventricle in a $0.3 \mathrm{ml}$ volume over a 15 sec period, followed by a $0.1 \mathrm{ml}$ flush of $0.9 \% \mathrm{NaCl}$ over another $15 \mathrm{sec}$ period. Blood withdrawal was started 30 sec before injection through the caudal arterial catheter at a rate of $0.656 \mathrm{ml} / \mathrm{min}$ by a Harvard suction pump and continued for 3 min after injection. Rats were killed by pentobarbital injection in the left ventricle, organs and tissues were excised. All tissues were blotted, weighed and counted in a two-channel gamma scintillation counter. Absolute blood flow was calculated by the reference sample method (23) and expressed as $\mathrm{ml} / \mathrm{min} / \mathrm{g}$ tissue. Relative flow was calculated as percentage of cardiac output.

\section{Statistics}

Data are expressed at means $\pm S E M$. The level of significance was set at $p<0.05$. For statistical analysis the following tests were used: The Mann-Whitney test (non-parametric) was used for individual comparison of the group means at 


\section{superior Mesenteric Artery}

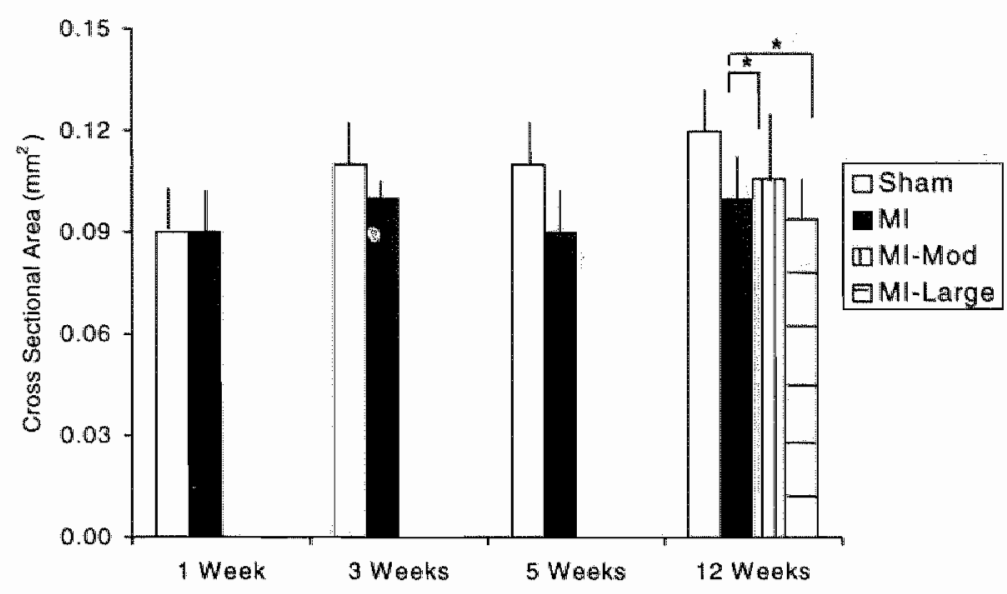

Figure 2.2: Medial cross-sectional area of the superior mesenteric artery at different time points after coronary artery ligation or sham-surgery. Statistical analysis: Effect over time by oneway ANOVA; sham rats $p=0.07$, $\mathrm{MI}$ rats $p=0.85{ }_{n}^{*} p<0.05$ by Mann-Whitney test.

specific time points. For the comparison of group means of sham-operated rats with rats of the MI-MOD and MI-LARGE groups, the Mann-Whitney with Bonferroni correction was used. One way ANOVA was used to test for effect in time.

Results

Characteristics of experimental groups: Characteristics of rats at the different time points are listed in table 2.1. Both $\mathrm{MI}$ and sham-operated controls increased in body weight during the experimental period. No differences were observed between groups. The mean infarct size for all Ml rats was $38 \pm 2 \%(n=32)$ and comparable between all $\mathrm{Ml}$ groups. To evaluate the effects of the degree of heart failure, rats of the 12 weeks group $(n=10)$ were subdivided in subgroups of moderate $(30 \pm 2 \%, n=5)$ and large $(49 \pm 4 \%, n=5)$ infarction.

Heart weights and heart-to-body weight ratios increased 5 and 12 weeks after coronary artery ligation (table 2.1). There was no evidence of oedema in the heart, as the mass fraction of water was comparable at all time points (data not shown). Lung weights of MI rats were increased compared to sham-operated controls at all time points, suggesting that induction of a myocardial infarction resulted in a substantial pulmonary oedema, indicative of heart failure. Also, changes in heart and lung weight became more pronounced as infarct size increased. 


\section{Pulmonary Resistance Arteries}

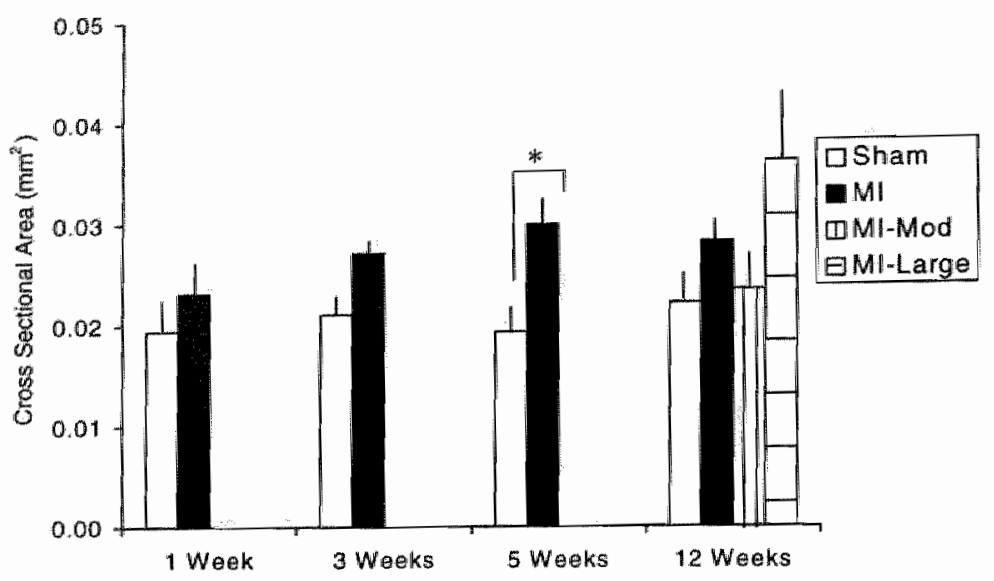

Figure 2.3: Medial cross-sectional area of the pulmonary resistance arteries at different time points after coronary artery ligation or sham surgery. Statistical analysis: Effects over time by oneway ANOVA; sham rats and MI rats $p=$ not significant, " $p<0.05$ by Mann-Whitney test.

\section{Vessel dimensions:}

Large conduit arteries (internal diameter $>600 \mu \mathrm{m}$ ): Changes in vessel dimensions of the large conduit arteries became evident as heart failure progressed. Only the data from the 12 weeks time point are shown (table 2.2). However, small changes were observed at earlier time points. Five weeks after coronary artery ligation, these changes consisted of smaller medial cross-sectional areas of the abdominal aorta (MI versus sham $-9 \%, p=0.06)$, carotid artery $(-25 \%, p=0.08)$ and renal artery $(-13 \%, p<0.05)$. Also, smaller external diameters of the thoracic aorta $(-5 \%$, $p=0.07)$, mesenteric artery $(-25 \%, p<0.05))$ and renal artery $(-15 \%, p=0.06)$ were observed as well as smaller internal diameters of the mesenteric artery $(-13 \%$, $p=0.06)$ and renal artery $(-16 \%, p=0.09)$. Twelve weeks after coronary artery ligation, smaller medial cross-sectional areas of the thoracic aorta and superior mesenteric artery were observed, as illustrated in figures 2.1 and 2.2, accompanied by a reduction in internal and external diameters (table 2.2). Similar changes were seen in the renal artery, carotid artery and the abdominal aorta (table 2.2). These changes coincided with a reduction in media-to-lumen ratio of the abdominal aorta, carotid and iliac artery (table 2.2).

Resistance arteries (internal diameter $<300 \mu \mathrm{m}$ ) : Internal and external diameters mesenteric and pulmonary resistance arteries (table 2.2, see also figure 2.3) were increased 12 weeks after coronary artery ligation, while media-to-lumen ratios 


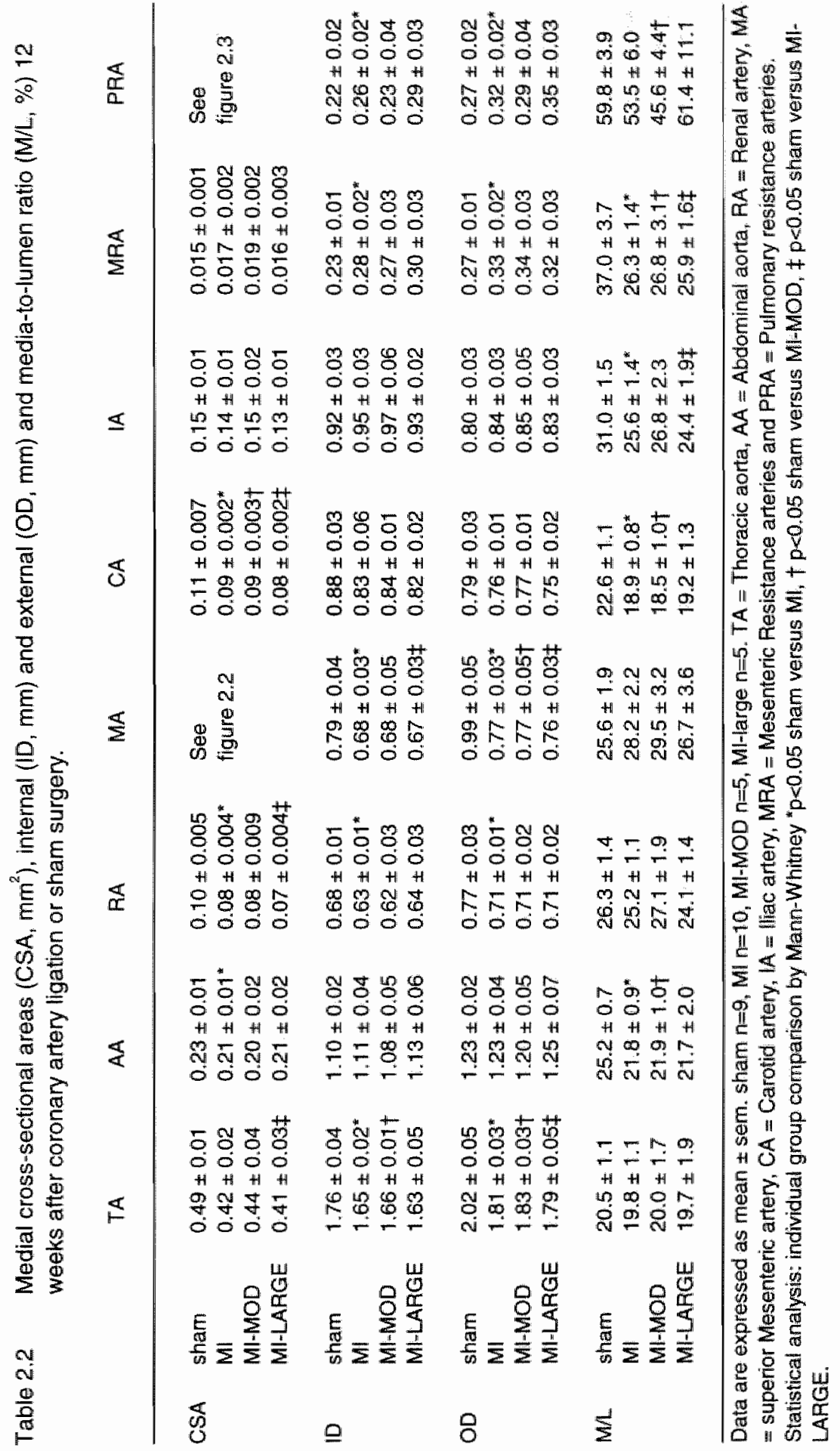


Table 2.3 Relative medial collagen and elastin content (\% positive area) of $M i$ and sham rats, 12 weeks after surgery.

TA AA SMA IA

\begin{tabular}{llllll}
\hline $\begin{array}{l}\text { Collagen } \\
\text { Sham }\end{array}$ & $20.6 \pm 2.0$ & $16.4 \pm 1.5$ & $21.2 \pm 1.9$ & $10.1 \pm 1.2$ & $13.8 \pm 1.2$ \\
MI & $22.1 \pm 1.0$ & $19.9 \pm 0.4$ & $24.4 \pm 1.2$ & $12.1 \pm 1.2$ & $16.1 \pm 1.1$ \\
MI-MOD & $21.1 \pm 1.4$ & $19.8 \pm 1.3$ & $23.3 \pm 3.8$ & $12.0 \pm 2.8$ & $1.3 .3 \pm 1.9$ \\
MI-LARGE & $23.1 \pm 3.3$ & $19.9 \pm 1.2$ & $26.0 \pm 2.3$ & $12.2 \pm 1.2$ & $18.9 \pm 1.3$
\end{tabular}

\section{Elastin}

Sham

MI

$26.6 \pm 2.0$

$15.3 \pm 0.8$

$22.3 \pm 1.7$

$28.5 \pm 1.5$

$16.4 \pm 1.6$

MI-MOD

$24.5 \pm 1.2$

$17.5 \pm 1.3$

$21.6 \pm 1.5$

$28.7 \pm 0.9$

$116.8 \pm 0.8$

MI-LARGE

$20.3 \pm 1.8$

$17.3 \pm 3.9$

$20.4 \pm 4.3$

$30.1 \pm 1.3$

$16.11 \pm 2.2$

$29.8 \pm 1.7$

$17.6 \pm 2.9$

$22.9 \pm 2.6$

$27.3 \pm 3.0$

$17.7 \pm 1.4$

Data are expressed as mean \pm sem. sham $n=9, M I n=10, M 1-M O D n=5, M 1$-large $n=5 . T A=$ Thoracic aorta, $\mathrm{AA}=\mathrm{Abdominal}$ aorta, $\mathrm{SMA}=$ superior Mesenteric artery, $\mathrm{CA}=$ Carotid artery, $\mid A=$ lliac artery. Statistical analysis: individual group comparison by Mann-Whitney test, no significant differences.

decreased (table 2.2). Cross-sectional areas of these arteries increased slightly, but this difference did not reach statistical significance.

\section{Extracellular matrix}

Volume fractions of collagen and elastin (table 2.3 , only 12 week time point is shown) measured by morphometric analysis were comparable in both sham and MI rats in the large conduit arteries during the entire experimental period. The hydroxyproline assay of these vessels confirmed this observation for the large conduit arteries and the renal artery (table 2.4). Also, medial DNA concentrations (expressed as ng/mg dry weight (table 2.4) or as $\mathrm{ng} / \mathrm{mm}$ vessel (data not shown) were similar between groups.

\section{Regional flow measurements}

Blood flow at rest was measured 5 and 12 weeks after coronary artery ligation. Again, infarcted groups were divided in moderate and large Ml's. At 5 weeks, a small decrease in cardiac output was observed (sham $401 \pm 30 \mathrm{ml} / \mathrm{min} / \mathrm{g}$ versus moderate Ml $303 \pm 42 \mathrm{ml} / \mathrm{min} / \mathrm{g}(\mathrm{p}=0.09)$ and sham versus large MI $307 \pm 35$ $\mathrm{ml} / \mathrm{min} / \mathrm{g}(p=0.07))$. Twelve weeks after coronary artery ligation, resting cardiac output did not differ between groups (sham $330 \pm 38 \mathrm{ml} / \mathrm{min} / \mathrm{g}$, moderate MI $308 \pm 38 \mathrm{ml} / \mathrm{min} / \mathrm{g}$, large MI $341 \pm 44 \mathrm{ml} / \mathrm{min} / \mathrm{g}$ ). In general, no major changes could 
Table 2.4 Absolute elastin and collagen content ( $\mu$ g hydroxyproline/ $\mu \mathrm{g}$ dry weight) and DNA concentration per vessel (ng DNA/mg dry weight) 12 weeks after coronary artery lighation or sham surgery.

\begin{tabular}{|c|c|c|c|c|c|c|}
\hline & \multicolumn{2}{|l|}{ ELASTIN } & \multicolumn{2}{|c|}{ COLLAGEN } & \multicolumn{2}{|l|}{ DNA } \\
\hline & Sham & $M I$ & Sham & $M I$ & Sham & $M$ \\
\hline TA & $13.8 \pm 0.9$ & $12.9 \pm 0.9$ & na & $4.9 \pm 0.4$ & $18.8 \pm 2.2$ & $21.5 \pm 6.2$ \\
\hline $\mathrm{CA}$ & $9.9 \pm 1.8$ & $9.3 \pm 1.0$ & $3.7 \pm 0.6$ & $4.6 \pm 1.9$ & $87.6 \pm 27.7$ & $89.9 \pm 21.9$ \\
\hline$A A$ & $9.9 \pm 0.8$ & $11.1 \pm 0.6$ & $3.9 \pm 0.5$ & $3.4 \pm 1.1$ & $51.8 \pm 20.5$ & $65.3 \pm 25.7$ \\
\hline sMA & $6.1 \pm 1.1$ & $5.9 \pm 1.0$ & $4.7 \pm 1.8$ & $5.9 \pm 1.0$ & $53.0 \pm 9.7$ & $75.7 \pm 26.2$ \\
\hline RA & $6.7 \pm 1.3$ & $7.5 \pm 2.1$ & $8.6 \pm 0.8$ & $6.3 \pm 1.7$ & $44.1 \pm 5.9$ & $65.2 \pm 30.8$ \\
\hline
\end{tabular}

Data are expressed as mean \pm sem. Pooled vessel segments, sham $n=3, M I n=3$, measured in duplo. $\mathrm{TA}=$ Thoracic aorta, $\mathrm{AA}=$ Abdominal aorta, $\mathrm{SMA}=$ superior Mesenteric artery, $\mathrm{CA}=$ Carotid artery, $R A=$ Renal artery. TA, CA and $A A$ represent mediall elastin and collagen concentrations, MA and RA represent total vessel (=medial and adventitial) elastin and collagen content. na=not available. Infarct size $=45 \pm 3 \%$. TA $=$ Thoracic aorta, $\mathrm{AA}=$ Abdominal aorta, $R A=$ Renal artery, $M A=$ superior Mesenteric artery, $C A=$ Carotid artery. Statistical analysis: Individual group comparison by Mann-Whitney test; MI rats compared to sham rats; no significant differences.

be observed in absolute or relative peripheral flow (not shown) in the examined tissues at both time points (5 weeks; table 2.5, 12 weeks; table 2.6). After 12 weeks, flow to gastro-intestinal tissues increased slightly, but liver flow was decreased.

\section{Discussion}

This study provides the first evidence for structural alterations of peripheral arteries in an experimental model of heart failure. Changes in vessel dimensions were, however, only present at the later time points examined. This might indicate that coronary artery ligation produced only mild heart failure. However, lung weights of Ml rats were increased proportional to infarct size at all time points, suggesting a substantial pulmonary oedema, indicative of heart failure. Also, infarct sizes comparable to the ones presented in this study $(38 \pm 2 \%)$ are known to induce a significant decrease in stroke volume and stroke work (18), a decrease in cardiac output after a volume overload (24) and elevated left ventricular end diastolic pressures $(25,26)$.

In contrast to the smaller diameters and medial cross-sectional areas of large conduit arteries, internal and external diameters of resistance arteries (mesenteric 
and pulmonary arteries) increased. Schieffer et al. (27) reported an increase in medial thickness of muscular resistance arteries one year after myocardial infarction. In our study, media-to-lumen ratios of the resistance arteries decreased, which is unexpected in view of the reported increase in peripheral resistance indicating resistance artery vasoconstriction during heart failure $(7,8)$. It should be reminded that perfusion fixation of the cardiovascular system was performed under maximal vasodilation. Thus, our data indicate that resistance arteries still have the potentiall for maximal vasodilation, and suggest that the observed vasoconstriction of resistance arteries during heart failure has a functional rather than a structural basis. An alternative possibility is that the vasoconstriction is primarily regulated in vascular beds other than the ones studied here. However, as the two resistance type arteries measured in this study showed the same phenomenon, this seems unlikely.

In contrast to sham rats, the medial cross-sectional area of large conduit arteries of MI rats did not increase during the experimental period. There are several possibilities to explain the smaller medial cross-sectional areas of the large conduit arteries. The first possibility is that the growth of $\mathrm{Ml}$ rats was retarded as compared to sham-operated rats. Medial cross-sectional areas of large arteries in sham rats increased over the 12 week time period, but the large conduit arteries of MI rats did not show this apparently normal growth pattern, as illustrated in figure 2.3 for the mesenteric artery. Body weights of $\mathrm{Ml}$ rats, however, were comparable to shams, indicating that this growth retardation in MI rats is not a general phenomenon, but specific for the large conduit arteries. The unchanged elastin and collagen contents (tables 2.3 and 2.4) and DNA concentration (table 2.4) after 12 weeks of coronary artery ligation in the media of these large conduit arteries suggest alterations in the control of vessel wall mass in $\mathrm{MI}$ rats, leading to the observed inhibition of growth of the large conduit arteries.

A reduction in peripheral flow may explain the inhibition of vascular growth of large conduit arteries. A decrease in flow has been shown to reduce vessel diameters and medial cross-sectional area $(28,29)$. During heart failure, a decrease in flow has been mentioned as a possible cause for abnormal skeletal muscle metabolism, but studies on measurements of peripheral flow changes during heart failure have yielded conflicting results. Most of these studies show decreased peripheral blood flow $(7,13,14,26,30,31)$, but some show unchanged blood flow (32-35). In our study, no major changes in resting peripheral blood flow were observed, despite the decrease in cardiac output after 5 weeks of heart failure (table 2.5) and a substantial ventricular damage of approximately $50 \%$ of left ventricular circumference. It should be noted that blood flow measurements were taken at rest and therefore possible flow changes during e.g. exercise cannot be excluded. Also, blood flow measurements were taken with a technique, that could be sensitive to potential errors (23). Taken together, it seems unlikely that the observed vascular changes are induced by 
Table 2.5 Regional Blood Flow (m//min/g) 5 weeks after coronany artery ligation or sham surgery.

Sham Moderate Mi (25 $\pm 3 \%$ Large MI (47\%4\%)

$\begin{array}{lllr}\text { Left Ventricle } & 6.63 \pm 1.85 & 9.23 \pm 0.68 & 9.5 \pm 0.61 \\ \text { Right Ventricle } & 5.18 \pm 1.33 & 6.08 \pm 1.37 & 5.98 \pm 0.48 \\ \text { Heart } & 11.0 \pm 2.83 & 15.3 \pm 1.52 & 14.5 \pm 1.26 \\ \text { Small Intestine } & 4.12 \pm 0.40 & 3.33 \pm 0.69 & 4.93 \pm 0.65 \\ \text { Large Intestine } & 1.03 \pm 0.12 & 0.90 \pm 0.22 & 1.10 \pm 0.11 \\ \text { Liver } & 0.61 \pm 0.08 & 0.96 \pm 0.12 & 0.93 \pm 0.16 \\ \text { Spleen } & 1.55 \pm 0.33 & 1.15 \pm 0.32 & 1.45 \pm 0.52 \\ \text { Kidneys } & 9.53 \pm 1.13 & 9.78 \pm 2.15 & 10.2 \pm 2.41 \\ \text { Soleus muscle } & 2.07 \pm 0.27 & 2.38 \pm 0.24 & 2.06 \pm 0.46 \\ \text { Gastrocnemicus muscle } & 0.53 \pm 0.09 & 0.36 \pm 0.15 & 0.27 \pm 0.05 \\ \text { Skin } & 0.18 \pm 0.03 & 0.20 \pm 0.04 & 0.22 \pm 0.04 \\ \text { Brain } & 1.41 \pm 0.13 & 1.67 \pm 0.22 & 1.46 \pm 0.22\end{array}$

Data are expressed as mean \pm sem. sham $n=9$, MI-MOD $n=5$, MI-LARGE $n=6$. Statistical analysis: individual group comparison by Mann-Whitney and Bonferroni correction * $p<0.025$ sham versus MI-MOD, $\uparrow p<0.025$ sham versus MII-LARGE.

Table 2.6 Regional Blood Flow ( $\mathrm{ml} / \mathrm{min} / \mathrm{g})$ in rats 12 weeks after coronary artery ligation or sham surgery.

Sham $\quad$ Moderate MI $(36 \pm 3 \%) \quad$ Large $M I(46 \pm 1 \%)$

$\begin{array}{lccl}\text { Left Ventricle } & 6.46 \pm 1.12 & 6.42 \pm 1.14 & 7.53 \pm 1.39 \\ \text { Right Ventricle } & 4.68 \pm 0.38 & 4.65 \pm 1.03 & 5.88 \pm 0.49 \\ \text { Heart } & 11.2 \pm 1.36 & 11.1 \pm 1.73 & 12.2 \pm 2.04 \\ \text { Small Intestine } & 2.99 \pm 0.28 & 4.22 \pm 0.56 & 4.28 \pm 0.39 \dagger \\ \text { Large Intestine } & 0.80 \pm 0.08 & 0.89 \pm 0.16 & 1.25 \pm 0.25 \dagger \\ \text { Liver } & 0.86 \pm 0.11 & 0.75 \pm 0.20 & 0.44 \pm 0.09 \dagger \\ \text { Spleen } & 1.22 \pm 0.09 & 1.57 \pm 0.41 & 1.42 \pm 0.28 \\ \text { Kidneys } & 9.60 \pm 1.50 & 9.93 \pm 1.21 & 9.89 \pm 2.24 \\ \text { Soleus muscle } & 2.34 \pm 0.42 & 1.96 \pm 0.41 & 1.90 \pm 0.29 \\ \text { Gastrocnemicus muscle } & 0.40 \pm 0.13 & 0.32 \pm 0.03 & 0.33 \pm 0.08 \\ \text { Skin } & 0.15 \pm 0.02 & 0.15 \pm 0.02 & 0.18 \pm 0.03 \\ \text { Brain } & 1.29 \pm 0.12 & 1.58 \pm 0.28 & 1.66 \pm 0.17\end{array}$

Data are expressed as mean \pm sem. sham $n=7$, MI-MOD $n=5$, MI-LARGE $n=6$. Statistical analysis: individual group comparison by Mann-Whitney and Bonferroni correction ${ }^{*} p<0.025$ sham versus MI-MOD, $\uparrow p<0.025$ sham versus MI-LARGE. 
changes in flow.

The smaller medial cross-sectional area of the large conduit arteries is remarkable in view of the described elevated plasma levels of several potential stimulators of vessel wall growth during heart failure. Human heart failure is associated with an increase in plasma levels of angiotensin $\|(36,37)$. catecholamines $(38,39)$ and endothelin $(40,41)$. This neurohumoral activation is considered to be important in cardiovascular adaptations during heart failure. For instance, angiotensin II is one of the regulators of cardiac remodeling and blood pressure after infarction $(18,24)$. The peptide also promotes vascular smooth muscle cell proliferation $(42,43)$ and synthesis of various extracellular matrix components $(44,45)$. Catecholamines and endothelin have also growthpromoting effects $(46,47)$. The apparent paradox, i.e. increased circulating levels of several potential stimulators of vessel wall growth, without increases medial cross-sectional area, may be explained by a concomitant increase in plasma levels of other factors that have growth inhibitory effects, like atrial natriuretic peptide and nitric oxide (NO), which are also elevated during heart failure (48-50). Both peptides have antimitogenic effects in cultured vascular smooth muscle cells (51-53). In vivo, infusion of non-pressor doses of atrial natriuretic peptide decreases medial thickness in spontaneous hypertensive rats (54), while NO is thought to be important in inhibition of neointima formation by angiotensinconverting enzyme-inhibitors in the rat balloon injury model (55). Elevations of both vasoconstrictor and vasodilating mediators during heart failure may serve functional hemodynamic purposes (e.g. maintenance of blood pressure) but may also have a diverse effect on the structure of the vascular system. One could hypothesize that during progressing heart failure a neurohumoral unbalance between counteracting systems becomes evident, with a dominating effect of potential inhibitors of vessel wall growth. This could result in a inhibition of large artery growth. Furthermore, the existence of different smooth muscle phenoand/or genotypes may explain the observed different response of conduit and resistance arteries during heart failure (56).

In summary, this study showed alterations in vessel dimensions of large conduit arteries during experimental heart failure. Moreover, changes became more pronounced as infarct size increased. Medial cross-sectional areas, internal and external diameters of large conduit arteries were smaller after 12 weeks in MI rats, compared to sham rats of the same age and weight, suggesting an inhibition of vascular growth. In contrast, internal and external diameters of resistance arteries were increased. It is suggested that following myocardial infarction both growth-stimulatory and inhibitory neurohormonal mechanisms are activated which over time lead to regional diverse adaptive changes in peripheral arteries. This diverse adaptation could have consequences for cardiac function during experimental heart failure. 


\section{References}

1. Heagerty AM, Aalkjaer C, Bund Sل, Korsgaard N, Mulvany MJ. Small artery structure in hypertension - Dual processes of remodeling and growth. Hypertension $1993 ; 21: 391-397$.

2. Mulvany MJ. Resistance vessel structure and the pathogenesis of hypertension. $J$ Hypertens 1993;11:S7-S12.

3. Wolinsky $\mathrm{H}$. Response of the rat aorta media to hypertension. Circ Res 1970;26: 507-522.

4. Walker-Caprioglio HM, Trotter JA, Little SA, McGuffee LJ. Organization of cells and extracellular matrix in mesenteric arteries of spontaneously hypertensive rats. Cell Tissue Res 1992;269:141-149.

5. Ross $\mathbb{R}$. The pathogenesis of atherosclerosis -an update. N Engl I Med 1986;314: 488-500.

6. Clowes AW, Reidy MA. Prevention of stenosis after vascular reconstruction: pharmacologic control of intimal hyperplasia- $A$ review. I Vasc Surg 1991;13:885-891.

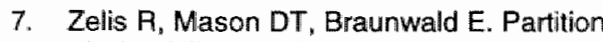
of blood flow to the cutaneous and muscular bed of the forearm at rest and during leg exercise in normal subjects and in patients with heart failure. Circ Res 1969; 24:799-806

8. Wilson JA, Matthai $W$, Lanoce $V_{\text {, Frey }} M_{1}$ Ferraro N. Effect of experimental heart failure on peripheral sympathetic vasoconstriction. Am J Physiol 1988;254:H727H733.

9. Zelis $R$, Mason DT. Diminished forearm arteriolar dilator capacity produced by mineralocorticoid-induced salt retention in man - Implications concerning congestiwe heart failure and vascular stiffness. Circukation 1970;41:589-592.

10. Zelis R, Mason DT, Braunwald E. A comparison of the effects of vasodilator stimuli on peripheral resistance vessels in normal subjects and in patients with congestive heart failure. J Clin Invest 1968;47:960.
970.

11. Zelis $R$, Delea CS, Coleman HN, Mason DT. Arterial sodium content in experimental heart failure. Circ Ries 1970,41:213216.

12. Stefanadis $C$, Stratos $C$, Boudoulas $H$, Kourouklis $C$. Toutouzas P. Distensibility of the ascending aorta: comparison of invasive and mon-invasive techniques in healthy men and in men with coronary artery disease. Eur Heart J 1990;11:990-996.

13. Musch TI, Terrell JA Skeletal muscle bloodflow abnormalities in rats with chronic myocardial infarction: rest and exercise. Am J Physiol 1992;262:H411-H419.

14. Sullivan MJ, Knight JD, Higginbotham MB, Cobb FR. Relation between central and peripheral hemodynamics during exercise in patients with chronic heart failure. Muscle blood flow is reduced with maintenance of arteriall perfusion pressure. Circulation 1989;80:769-781.

15. Cleland JGF, Oakley CM. Vascular tone in heart failure: the neuroendocrine-therapeutic interface. Br Heart $J 1991 ; 66: 264-267$.

16. Packer $M$. Pathophysiology of chronic heart faillure. Lancet 1992;340:88-92.

17. Fishbein MC, Maclean D, Maroko PR. Experimental myocardial infarction in the rat. Asn J Pathol 1978;90:57-70.

18. Schoemaker RG, Debets JJM, StruykerBoudier HA. Smits JFM. Delayed but not immediate captopril therapy improves cardiac function in conscious rats following myocardial infarction. J Mol Cell Cardiol 1991;23:187-197.

19. Dolber PC, Spach MS. Picrosirius red staining of cardiac muscle following phosphomolybdic acid treatment. Stain Technol 1987;62:23-26.

20. Schoemaker RG, Urquhart J, Debets JJM, Struyker Boudier HAJ, Smits JFM. Acute hemodynamic effects of coronary artery ligation in conscious rats. Basic Res Car- 
diol 1990;85:9-20.

21. Todorovich-Hunter L, Johnson DJ, Ranger $P$, Keeley FW, Rabinowitch M. Altered elastin and collagen synthesis associated with progressive pulmonary hypertension induced by monocrataline. A biochemical and ultrastructural study. Lab Invest 1988 ; 58:184-185.

22. Keeley FW, Elmoselhi $A$, Leenen FH. Enalapril suppresses normal accumulation of elastin and collagen in cardiovascullar tissues of growing rats. Am J Physiol 1992 262:H1013-H1021.

23. Flaim SF, Nellis SH, Toggart EJ, Drexler $H$. Kanda K, Newman ED. Multiple simultaneous determinations of hemodynamics and flow distribution in conscious rat. I Pharmacol Methods 1984:11:1-39.

24. Smits JFM, Van Krimpen $C_{n}$ Schoemaker RG, Cleutjens JPM, Daemen MUAP. Angiotensirn-1I receptor blockade after myocardial infarction in rats - Effects an hemodynamics, myocardial DNA synthesis, and interstitial collagen content. $J$ Cardiovasc Pharmacol 1992;20:772-778.

25. Drexler H, Flaim SF, Toggant EJ, Glick $M R$, Zelis $R$. Cardiocirculatory adjustments to exercise following myocardial infarction in rats. Basic Res Cardiol 1986; 81:350-360.

26. Drexler $H$, Toggart EJ, Glick MR, Heald d, Flaim SF, Zelis $\mathrm{A}$. Regional vascular adjustments during recovery from myocardial infarction in rats. I Am Coll Cardial $1986 ; 8: 134-142$.

27. Schieffer $B_{1}$ Wollert $K G$, Berchtold $M_{n}$ Saal $K$, Riede U, Drexler H. Development and prevention of skeletal muscle structural alterations in experimental chronic heart failure. Circulation 1994;90; $1-262$.

28. Langille $\mathrm{BL}$, Bendeck MP, Keeley FW. Adaptations of carotid arteries of young and mature rabbits to reduced carotid blood flow. Am J Physiol 1989;256:H931. H939.

29. Guyton $\mathrm{J}$, Hartley CJ. Flow restriction of one carotid artery in jumenile rats inhibits growth of arterial diameter. Am I Physiol $1985 ; 248: H 540-H 546$.
30. Drexler $H$, Hirth $C$, Stasch HP, Lu W, Neuser $D$. Just $H$. Vasodilatory action of endogenous atrial natriuretic factor in a rat model of chronic hear failure as determined by monoclonal ANF antibody. Circ Res 1990;66:1371-1380.

31. Drexler $H$, Depenbusch JW, Truog $A G$, Zelis $R$, Flaim SF. Acute regional vascular effects of intravenous captopril in a rat model of myocardial infarction and lailure. J Pharm Exp Therp 1987;241:13-19.

32. Musch TI, Moore RL, Leathers DJ, Bruno $A$, Zelis $R$. Endurance training in rats with chronic heart failure induced by myocardial infarction. Circulation 1986;74:431-441.

33. Wiener DH, Fink $L$, Maris $J$, Jones RA, Chance B, Wilson JR. Abnormal skeletal muscle bioenergetics during exercise in patients with heart failure: role of reduced muscle blood flow. Circulation 1986; 73: $1127-1136$.

34. Massie $B$, Conway $M$, Yonge $R_{n}$ Frostick $S$, Ledingham J, Sleight $P$, Radda G, Rajagopalan B. Skeletal muscle metabolism in patients with congestive heart failure: relation to clinical severity and blood flow. Circulation 1987;76:1009-1019.

35. Massie BM, Conway $M$, Rajagopalan $B$, Yonge $R$, Frostick $S_{x}$ Ledingham J, Sleight P. Radda G. Skeletal muscle metabolism during exercise under ischemic conditions in congestive heart lailure. Evidence for abnormalities unrelated to blood fiow. Circulation 1988;78:320-326.

36. McAlpine $\mathrm{HM}_{1}$ Morton JJ, Leckie B, Rumley A, Gillen G, Dargie HJ. Neuroendocrine activation after acute myocardial infarction. Br Heart $J$ 1988;60:117-124.

37. Swedberg $K$, Eneroth $P$, Kjekshus J, Wilhelmsen $L$. Hormones regulating cardiovascular function in patients with severe congestive heart failure and their relation to mortality. Circulation 1990; 82:1730-1736.

38. Davis D, Baily R, Zelis R. Abnormaities in systemic norepinephrine kinetics in human congestive heart failure. Am I Physiol 1988;254:E760-E766.

39. Davis $D$, Sinoway $L L_{1}$ Robison J, Minotti JR, Day FP, Baily $R$, Zelis R. Norepine- 
phrine kinetics during orthostatic stress in congestive heart failure. Circ Res 1987; 61:187-190.

40. Tomoda $\mathbb{H}$. Plasma endothelin-1 in acute myocardial infarction with heart failure. Am Heart $J 1993 ; 125: 667-672$.

41. Wei C, Lerman A, Rodeheffer RJ, McGregor CGA, Brandt RR, Wright $S$, Heublein DM, Edwards WD, Burnett JC. Endothelin in human congestive heart failure. Circula. tion 1994;89:1580-1586.

42. Geisterfer AA, Peach MJ, Owens GK. Angiotensin II induces hypertrophy, not hyperplasia, of cultured rat aortic smooth muscle cells. Circ Res 1988;62:749-756.

43. Daemen MJ, Lombardi DM, Bosman FT, Schwartz SM. Angiotensin II induces smooth muscle cell proliferation in the normal and injured rat arterial wall. Circ Res 1991;68:450-456.

44. Kato $H$, Suzuki $H$, Tajima $S$, Ogata $Y$, Tominaga $T$, Sato $A$, Saruta T. Angiotensin II stimulates collagen synthesis in cultured vascular smooth muscle cells. $J$ Hypertens 1991;9:17-22.

45. Crawford DC, Chobanian AV, Brecher P. Angiotensin II induces fibronectin expression associated with cardiac fibrosis in the rat. Circ Res 1994;74:727-739.

46. Yamori $Y$, Mano $M$, Nara $Y$, Horie $R$. Catecholamine-induced polyploidization in vascular smooth muscie cells. Circulation $1987 ; 75: 192-195$.

47. Chua BHL, Krebs CJ, Chua CC, Diglio CA. Endothelin stimulates protein synthesis in smooth muscle cells. Am J Physio 1992;262:E412-E416.

48. Swanegaard $J$, Angelo-Nielsen $K$, Pindborg $T$. Plasma concentration of atrial natriuretic peptide at admission and risk of cardiac death in patients with acute myocardial infarction. Br Heart $J 1992 ; 68: 38$ 42.

49. Cody Rul, Kubo SH, Laragh JH, Atlas SA. Cardiac secretion of atrial natriuretic factor with exercise in chronic congestive heart failure patients. J Appl Physiol 1992; 73:1637-1643.
50. Winlaw DS, Smythe GA, Keogh AM, Schyvens CG, Spratt PM, MacDonald PS. Increased nitric oxide production in heart failure. Lancet 1994;344:373-374.

51. Itoh H. Pratt RE, Dzau VJ. Atrial Natriuretic Polypeptide inhibits hypertrophy of vascu. lat smooth muscle cells. J Clin invest 1990;86:1690-1697.

52. Porter JG, Catalano $R$, McEnroe $G$, Lewicki JA, Protter AA. C-type natriuretic peptide inhibits growth factor-dependent DNA synthesis in smooth muscle cells. Am J Physiol 1992;263:C1001-C1006.

53. Nunokawa $Y$, Tanaka S. Interferon-gamma inhibits proliferation of rat vascular smooth muscle cells by nitric oxide generation. Biochem Biophys Res Commun 1992; 18:8:409-415.

54. Mourlon-le Grand MC, Poitevin P, Benessiano J, Duriez M, Michel JB, Levy Bl. Effect of a nonhypotensive lang-term infusion of ANP on the mechanical and structural properties of the arterial wall in WistarKyoto and Spontaneously Hypertensive Rats. Arteriosel Thromb Vasc Biol 1993; 13:640-650.

55. Farhy RD, Carretero OA, Ho K, Scicli AH. Role of kinins and nitric oxid in the effects of anglotensin converting enzyme inhibitors on neointima formation. Circ Res 1993;72:1202-1210.

56. Daemen MJAP, De Mey JGR. Regional heterogeneity of arterial structural changes. Hypertension 1995:25:464-473. 


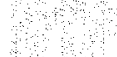




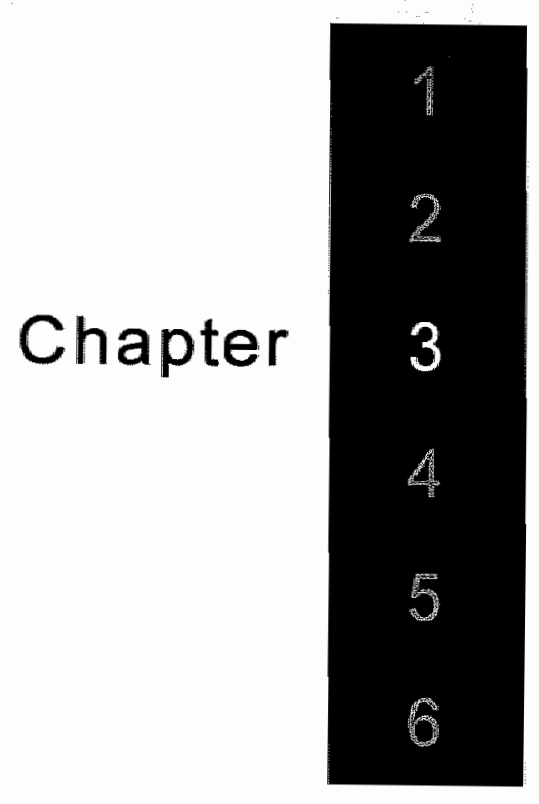

\section{Effects of Angiotensin II on Cardiac Function and Peripheral Vascular Structure during Compensated Heart Failure in the Rat}

Sylvia Heeneman, Jos Smits, Peter Leenders, Paul Schiffers, Mat Daemen

Arterioscler. Thromb. Vasc. Biol. 1997; in press 


\section{Chapter 3}

\begin{abstract}
Background: The present experiments were designed to test the hypothesis that activation of the renin-angiotensin system during compensated heart failure may have adverse effects on cardiac function and change peripheral vascular structure. ANG I| (250 $\mathrm{ng} / \mathrm{kg} / \mathrm{min})$ or saline $(0.9 \% \mathrm{NaCl})$ were infused in myocardial infarcted and sham rats. After 2 weeks, cardiac function and peripheral vascular changes were investigated. Resu/ts: ANG II infusion reduced baseline cardiac index in sham rats, but did not further reduce this index in ANG II infused MI rats. Total peripheral resistance was similarly increased in ANG II infused infarcted and sham rats and also plasma ANG || concentrations were comparable. ANG II elevated systolic blood pressure by approximately $70 \mathrm{mmHg}$ in sham rats and increased medial cross-sectional area of the superior mesenteric artery by $33 \%$. However, ANG II infusions in MI rats resulted in only a minor increase in blood pressure whereas the cross-sectional area of the superior mesenteric artery did not change. ANG II infusion had no effect on vessel dimensions of
\end{abstract}

\begin{abstract}
resistance arteries of the pulmonary and mesenteric vascular bed of either group. Calculated $E D_{50}$ and peak pressor response to acute ANG II injections were comparable in all groups, confirming the presence of functionally intact AT1 receptors. The increases in plasma atrial natriuretic peptide (ANP) and nitric oxide (NO) synthase activity (estimated by aortic cyclic GMP concentrations) were higher in ANG II infused $M I$ rats, than in ANG II infused sham rats. Conclusion: ANG $\|$ infusion in rats with and without MI has comparable negative effects on cardiac function, but has different effects on blood pressure and vascular structure. The concomitant increases in plasma ANP and NO synthase activity in ANG $\|$ infused $M I$ rats suggest that growth-stimulatory and hypertensive actions of ANG II in sham rats may be counte-regulated by activation of inhibitory neurohumoral systems such as ANP or NO in MI rats.
\end{abstract}




\section{Introduction}

The renin-angiotensin system (RAS) is one of the most extensively studied neurohumoral systems in the pathophysiology of congestive heart failure. Angiotensin II (ANG II), the effector peptide of the RAS, is involved in the regulation of cardiovascular function and volume homeostasis by raising peripheral resistance through vasoconstriction, stimulating aldosterone release and enhancing renal sodium reabsorption (1). Given its important role in maintaining circulatory homeostasis, one can expect an activation of the RAS in a situation of a decreased cardiac output, as seen during heart failure. An interesting aspect of RAS activation during heart failure is the timing. Plasma concentrations of ANG II are increased in the acute phase after myocardial infarction, normalize in the compensated phase and increase again in overt heart failure (2-4). This biphasic activation is considered to be a compensatory mechanism in response to decreased cardiac function. Although this may well be true for the first phase, it may not be true for the second phase in which activation of the renin angiotensin system may even have adverse effects on function and/or structure of the cardiovascular system. Indeed, a significant positive correlation between mortality and plasma levels of ANG II has been shown in patients with heart failure $(5,6)$ and it has been suggested that the effect of ACE-inhibition is related to neurohormonal activation in general and the RAS in particular (6).

To test the hypothesis that increased plasma concentrations of ANG II have adverse effects on cardiac function in conditions of an already reduced cardiac output, we infused ANG II in rats 2 weeks after induction of a myocardial infarction and studied cardiac function. This timing and model were chosen since we knew already from our own work as well as that from other groups that cardiac function is decreased in this model and that plasma levels of ANG II are not elevated at this time $(2,7-9)$. Since it is also known that peripheral vascular alterations do occur after induction of a myocardial infarction and that ANG II has strong effects on vascular structure $(10,11)$, we also studied the effects of ANG II on vascular structural parameters.

The results show that infusion of ANG II in MI rats had similar effects on cardiac function in $\mathrm{Ml}$ and sham rats. The increases in mean arterial pressure and vessel wall mass were, however, smaller in Ml rats than in sham rats. We suggest that activation of inhibitory neurohumoral systems such as ANP and NO may be responsible for suppression of hypertensive and growth stimulatory effects of ANG II in MI rats.

\section{Materials and methods}

\section{Animals}

Male Wistar rats $(n=161,200-250 \mathrm{~g}$ at the start of training on day -14 , 
Winkelmann, Borchen, Germany) were housed under standard conditions and fed standard rat chow (RMH-TM, Hope Farms, Woerden, The Netherlands) and water ad libitum. The experiments were performed in accordance with local institutional guidelines. The randomization scheme is shown in figure 3.1. Of the 161 rats used, 26 died following coronary artery ligation and 2 following sham surgery. Of the 133 remaining rats; 39 were used for measurement of cardiac function and hemodynamics (experiment 1), 46 were used in the final evaluations of experiment 2 (tail cuff plethysmography and morphometric measurements), and 39 rats for experiment 3 (blood sampling and excision of thoracic aorta). The remaining 9 rats had infarct sizes less than $20 \%$ of left ventricular circumference, or showed non-transmural infarcts.

\section{Coronary artery ligation}

Myocardial infarction (MI) was induced by ligation of the left anterior descending coronary artery (LAD) according to the method of Fishbein (12) as described in chapter 2.

\section{Experimental protocol}

Rats were randomly assigned to either the protocol for measurement of hemodynamics and cardiac function (experiment 1, $n=39$ ), tail cuff plethysmography and morphometric measurements (experiment $2, n=46$ ) or blood sampling (experiment $3, n=39$ ) as outlined in figure 3.1. For each study, rats were assigned to one of the following 4 groups: $\mathrm{SH}-\mathrm{NaCl}$ underwent a sham operation and were infused with saline $(0.9 \% \mathrm{NaCl})$. $\mathrm{MI}-\mathrm{NaCl}$ were infused with saline following infarct induction. SH-ANG and MI-ANG were subjected to sham surgery and myocardial infarction respectively, and infused with ANG II. The number of animais per group is presented in figure 3.1 .

Infusions: ANG II (human [ ${ }^{5} \mathrm{Val}$ ] ANG $\|, 250 \mathrm{ng} / \mathrm{kg} / \mathrm{min}$, Brunschwig, Amsterdam, The Netherlands) dissolved in saline or saline were infused subcutaneously for 2 weeks by osmotic minipumps (Alzet model 2002, Alza Corporation, Palo Alto, California), implanted subcutaneously between the shoulder blades. Minipumps were inserted at day 0.

Experiment 1: In this study, hemodynamic measurements were performed on saline and ANG II infused sham and MI rats. These rats were implanted with an electromagnetic probe and various catheters to determine cardiac and peripheral hemodynamics.

Implantation of measuring equipment. 7 Days after coronary artery ligation or sham surgery and implantation of osmotic minipump, all rats were equipped with an electromagnetic flow probe (2.7 $\mathrm{mm}$ diameter; Skalar, Delft, The Netherlands) on the ascending aorta according to previously described methods (7). Rats were anesthetized with sodium pentobarbital $(60 \mathrm{mg} / \mathrm{kg}$ i.p.). After endotracheal intubation and start of positive pressure respiration, the thorax was opened in the 


\section{Study Protocol}

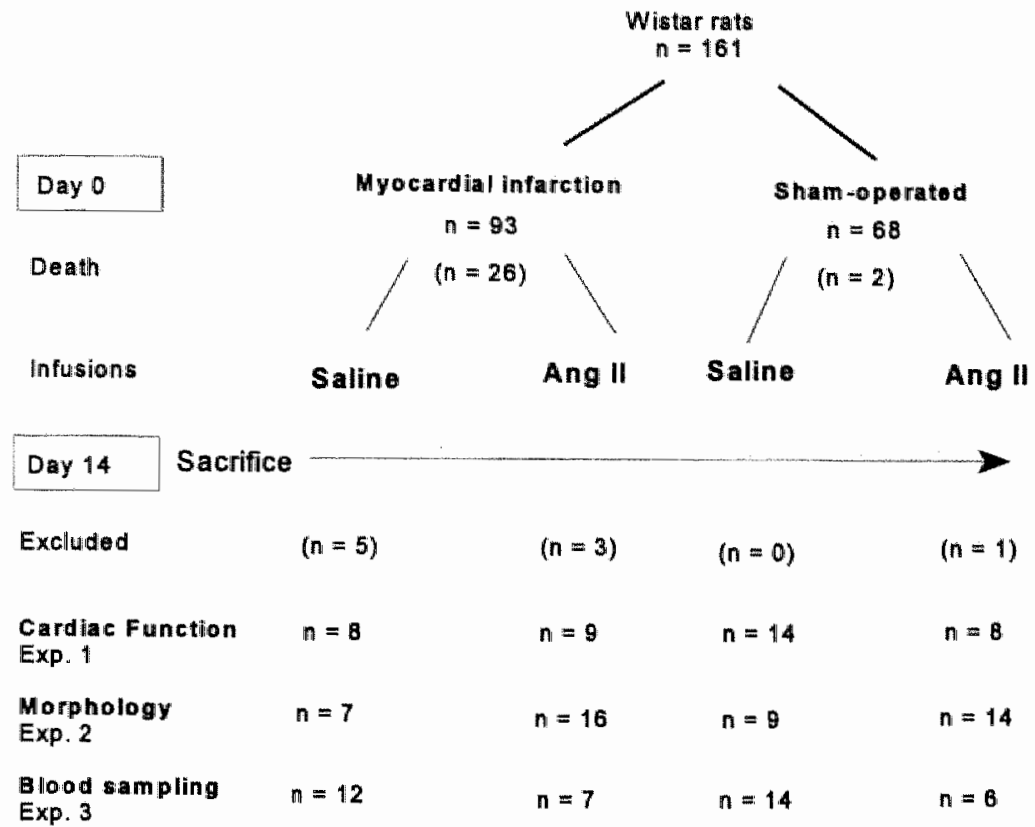

Figure 3.1 Outline of research protocol with randomization scheme

third right intercostal space and the ascending aorta was dissected from surrounding tissue. An electromagnetic flow probe was placed around the aorta at 1 $2 \mathrm{~mm}$ above the heart. The thorax was closed in layers, the cable was fixed to the ribs, and the connector was exteriorized in the neck where it was sutured to the skin.

Four days later (day 11), rats were anesthetized with ether and implanted with a PE-10 catheter in the abdominal aorta through the right femoral artery to measure arterial blood pressure. Furthermore, through the right femoral vein, a PE-10 catheter was implanted into the abdominal vena cava for infusions. A Silastic (602-175, Dow Corning, Midland, MI, USA) catheter was placed in the thoracic vena cava for measurement of central venous pressure. All catheters were exteriorized in the neck, filled with saline, and closed with metal plugs. After these operations, rats were allowed to recover for 3 days before hemodynamic measurements.

Measurements and protocol: On day 14, the electromagnetic flow probe was connected to a sinewave flowmeter (model MDL 401, Skalar) to measure blood flow through the ascending aorta. Although this flow comprises cardiac output 
minus coronary blood flow, we refer to it as cardiac output. The baseline was established by taking late diastolic blood flow as zero. The arterial and central venous catheters were connected to low-volume displacement pressure transducers (CP01; Century Technology, Inglewood, $\mathrm{Ca}$, USA). Mean values for arterial blood pressure and central venous pressure were obtained by digital integration. Stroke volume was calculated from the flow signal by integration of each beat. Total peripheral resistance was calculated as (mean arterial pressure central venous pressure)/ cardiac output. Stroke work was estimated by multiplying stroke volume with the difference between mean arterial pressure and central venous pressure. All derivations were made on-line and stored on disk for later processing.

After 45-60 $\mathrm{min}$, baseline recordings were made for $15 \mathrm{~min}$. Then a rapid infusion of $12 \mathrm{ml}$ of a warm $\left(37^{\circ} \mathrm{C}\right)$ Ringer's solution was given in 1 min through the abdominal caval vein catheter. This has been shown to increase cardiac output to a plateau level, which can be used as an indicator of maximal cardiac function. (7) During this period, hemodynamics were monitored continuously. The plateau cardiac output was obtained during the final 10-15 $s$ of the volume loading and is termed "maximal cardiac output during volume loading". The values for cardiac output and stroke volume (at baseline and during volume loading) were normalized for body weight and termed cardiac index and stroke volume index.

After the measurements, rats were killed using an overdose of pentobarbital, after which the heart was arrested in diastole by injecting $\mathrm{CdCl}_{2}(0.1 \mathrm{M})$ into the inferior caval vein. The heart was excised and weighed after removal of the atria. Lungs were also excised and weighed. The heart was then fixed overnight in $10 \%$ phosphate buffered formalin and processed and embedded in paraplast via routine histological procedures. Infarct size was determined on AZAN stained sections $(4 \mu \mathrm{m})$ on a computerized morphometric system (Quantimet 570 , Leica, Cambridge, U.K.) of a slice of the heart taken at the level of the papillary muscle. Infarct size was expressed in percent of left ventricular circumference.

Experiment $2:$ In this study, systolic blood pressures were measured by tail cuff plethysmography throughout the protocol. Prior to sacrifice on day 14 , mean arterial blood pressures were measured through an arterial catheter, and some of the rats were used for a cumulative ANG II pressor dose response curve.

Tail cuff plethysmography: Systolic blood pressures were measured by tailcuff plethysmography (IITC Inc, Life Science instruments, Woodland Hills, CA, USA) in conscious rats. During 7 days (day -14 to day -8 ), rats were trained for the procedure. Measurements started 1 week before surgery (day -7 to day 0 ) and continued during infusions. Blood pressures and heart rates were measured three times a week. The mean of 4-5 measurements per animal in one session was used for calculations.

Assessment of mean arterial pressures and heart rates on day 14. On day 13 , rats were anesthetized with sodium pentobarbital $(60 \mathrm{mg} / \mathrm{kg}$ i.p.) and provided 
with a polyethylene (PE10) catheter in the abdominal aorta through the left femoral artery to measure mean arterial blood pressure. The catheter was exteriorized in the neck, filled with saline and closed with a metal plug. On day 14, the arterial catheter was connected to low-volume displacement pressure transducers (CP01; Century Technology, Inglewood, Ca, USA). All signals were fed into a microcomputer, sampling all signals at $500 \mathrm{~Hz}$ each. Mean values for arterial blood pressure and heart rates were obtained by digital integration.

Assessment of cumulative ANG // pressor response curve: On day 14, some of the rats assigned to this study protocol $(\mathrm{SH}-\mathrm{NaCl} n=7, \mathrm{MI}-\mathrm{NaCl} n=7, \mathrm{SH}$ ANG $n=6, M I-A N G \quad n=6)$ were anesthetized with pentobarbital $(60 \mathrm{mg} / \mathrm{kg}$ intraperitoneal) and a PE10 catheter was implanted in the right jugular vein. The previously implanted arterial catheter was connected to the same system as described above. An ANG II dose-blood pressure response curve in a dose ranging from $0.3 \mathrm{ng}$ to $30 \mu \mathrm{g}$ ANG II was determined, while body temperature was maintained at $37^{\circ} \mathrm{C}$ using heating pads. To minimize interference of tachyphylaxis, doses were given cumulatively, with each successive injection given immediately after the maximum effect of the preceding dose was achieved (10-20 s). The dose at the half-maximal effect $\left(E D_{50}\right)$ was computed by fitting the mean arterial pressure response to $A N G \|$ to a sigmoidal curve using the equation

$$
\frac{\Delta M A P=\Delta M A P_{\max } \times D^{n}}{E d^{n}{ }_{50}+D^{n}}
$$

where $\triangle M A P_{\max }=$ maximal increase in mean arterial pressure, $D=$ dose of $A N G$ $\|$ and $n=$ Hill-coefficient

For tissue processing (heart and vessels) and morphometric measurements, see materials and methods of chapter 2.

Experiment 3 : In this protocol, blood samples were taken for determination of plasma ANG II and atrial natriuretic peptide (ANP) in ANG II and saline infused MI and sham rats. Also, the thoracic aorta was excised for determination of cyclic GMP (cGMP) concentrations (13). In these groups of rats, mean arterial pressures were measured on day 15 .

Blood sampling. On day 13 , rats were provided with a polyethylene (PE10) catheter in the abdominal aorta through the left femoral artery, as described above. On day 14 , blood $(2 \mathrm{ml})$ was sampled from the arterial catheter in nondisturbed rats and collected in chilled heparinized tubes, containing $1.4 \mu \mathrm{M}$ enalaprilate. Tubes were centrifuged at $3000 \mathrm{RPM}$ at $4^{\circ} \mathrm{C}$ for $15 \mathrm{~min}$ and stored at $-70^{\circ} \mathrm{C}$ until plasma ANG II and ANP measurements.

Due to blood sampling, measurement of mean arterial pressures in these rats was postponed to day 15. After these measurements (see experiment 2), rats were killed using an overdose of pentobarbital. As in experiment 1 , the heart was arrested in diastole, by injecting $1-2 \mathrm{ml} \mathrm{CdCl}_{2}(0.1 \mathrm{M})$ into the inferior caval vein. 
The thoracic aorta was rapidly excised, rinsed in cold buffered saline, frozen in liquid nitrogen and stored at $-70^{\circ} \mathrm{C}$. Heart and lungs were excised and weighed. The heart was then prepared for infarct size measurement as described in experiment 1.

Detection of plasma angiotensin /I and ANP concentrations. Plasma ANG \|I and ANP concentrations were measured using a radioimmunoassay. For ANG II, plasma samples $(0.5 \mathrm{ml})$ were extracted using ethanol. For ANP, plasma samples $(0.5 \mathrm{ml})$ were acidified with $1.5 \mathrm{ml} 4 \%$ acetic acid and ANP was eluted from a $\mathrm{C}^{18}$ column (Millipore, Waters Chromotography, Etten-Leur, The Netherlands) by applying $3 \times 1 \mathrm{ml} 4 \%$ acetic acid in $86 \%$ ethanol at the top of the column. Both collected eluates were evaporated to dryness in a vacuum evaporator. The dried extracts were reconstituted by adding assay buffer to each tube and then stored at $-15^{\circ} \mathrm{C}$.

Radiolabeled ANG II (Dupont, NEN products, Dordrecht, the Netherlands) and ANP (Nichols Institute, Diagnostics B.V., Wijchen, The Netherlands) competed with unlabeled ANG II and ANP in the test samples and standards for a limited number of specific antibody binding sites. At the end of the incubation period (42 h), antibody-bound ANG II and ANP were separated from unbound ANG II and ANP using anti-rabbit coated cellulose (Nichols Institute, Diagnostics B.V., Wijchen, The Netherlands) in suspension as a solid phase. Following a brief incubation and centrifugation, the unbound ANG II and ANP were decanted and the antibody-bound radiolabeled ANG II and ANP measured in a gamma counter. A standard curve was prepared and the test sample concentrations were read from the curve. Intra- and interassay variations are $4.9 \%$ and $7.9 \%$ for ANG II and $6.9 \%$ and $12.7 \%$ for ANP.

Tissue sampling: Thoracic aorta's were powered with a mortar and pestle, placed in liquid nitrogen. Tissues were further homogenized in $6 \%$ trichloroacetic acid (TCA) with an ultra turrax at $4^{\circ} \mathrm{C}$, centrifuged at $4000 \mathrm{~g}$ for 10 minutes at $4^{\circ} \mathrm{C}$ and the supernatant was transferred to a clean test tube. TCA was removed from the supernatant by extracting three times with three volumes of water-saturated diethyl ether. Samples were then dried under nitrogen and stored at $-20^{\circ} \mathrm{C}$ untill assayed.

Determination of cyclic GMP concentration: The cGMP content of thoracic aorta segments was determined with a commercially available kit ( ${ }^{125} \mid$-cGMP-RIA, IBL, Hamburg, Germany). The residues were dissolved in $300 \mu$ l assay buffer of which $100 \mu \mathrm{l}$ was used for the assay. $100 \mu \mathrm{l}^{125} \mathrm{l}$ - tracer and $200 \mu \mathrm{l}$ antiserum were added. Samples for the standard curve and non-specific- binding were prepared according to the same procedure. After an incubation of 24 hours at $4^{\circ} \mathrm{C}$, cooled separation reagent was added after which the tubes were centrifuged. The supernatant was discarded and residual radioactivity was counted in a gamma counter. The protein content was measured using a commercially available assay (Biorad protein assay, Biorad Lab. München, Germany) and cGMP values are presented as femtomoles per mg protein. 


\begin{tabular}{|c|c|c|c|c|}
\hline \multirow[b]{2}{*}{ Variable } & \multicolumn{2}{|c|}{ Saline infused } & \multicolumn{2}{|c|}{ ANG $\|$ infused } \\
\hline & Sham & MI & Sham & MI \\
\hline BW day 14 & $293 \pm 5$ & $278 \pm 5^{*}$ & $245 \pm 4^{*}$ & $254 \pm 6+$ \\
\hline Gain of BW $(g)$ & $-24 \pm 3$ & $-31 \pm 7$ & $-40 \pm 4^{*}$ & $-35 \pm 8$ \\
\hline$H W(g)$ & $0.85 \pm 0.02$ & $0.80 \pm 0.03$ & $0.86 \pm 0.02$ & $0.93 \pm 0.06$ \\
\hline HW/BW $(\mathrm{g} / \mathrm{kg})$ & $2.9 \pm 0.1$ & $2.9 \pm 0.1$ & $3.5 \pm 0.1^{*}$ & $3.7 \pm 0.3$ \\
\hline LW/BW (g/kg) & ND & ND & $5.3 \pm 0.3$ & $7.7 \pm 1.1$ \\
\hline Infarct size (\%) & & $46 \pm 4$ & & $47 \pm 4$ \\
\hline HR (beats/min) & $360 \pm 14$ & $376 \pm 9$ & $387 \pm 13$ & $391 \pm 25$ \\
\hline $\mathrm{SW}(\mathrm{mmHg} / \mathrm{min})$ & $23 \pm 1$ & $16 \pm 1^{*}$ & $26 \pm 2$ & $16 \pm 1 \#$ \\
\hline MAP $(\mathrm{mmHg})$ & $97 \pm 2$ & $88 \pm 4$ & $166 \pm 8^{*}$ & $122 \pm 7 \dagger$ ， \\
\hline TPR $(\mathrm{mmH} / \mathrm{g} / \mathrm{min} / \mathrm{ml})$ & $1.2 \pm 0.1$ & $1.5 \pm 0.2$ & $2.9 \pm 0.3^{*}$ & $2.4 \pm 0.2 \dagger$ \\
\hline $\operatorname{CVP}\left(\mathrm{cm} \mathrm{H}_{2} \mathrm{O}\right)$ & $0.2 \pm 0.4$ & $-0.7 \pm 0.7$ & $-1.1 \pm 0.7$ & $-3.2 \pm 1.2$ \\
\hline$n$ & 14 & 8 & 8 & 9 \\
\hline
\end{tabular}

Table shows gain of body weights (BW) during 14 days of infusions, heart weight (HW), heart-to-body weight ratios (HW/BW), lung-to-body weight ratios (LW/BW), infarct size, heart rates (HR), stroke work (SW), mean arterial pressures (MAP), total peripheral resistance (TPR) and central venous pressure (CVP). ND = not determined. Data are expressed as mean \pm sem. Statistical analysis: Intergroup differences were tested by Mann-Whitney tests with a Bonferroni correction for multiple group comparison; " $\mathrm{p}<0.0125$ compared to saline infused sham rats, $\uparrow p<0.0125$ compared to saline infused $M I$ rats and $\neq p<0.0125$ compared to ANG II infused sham rats.

\section{Statistics}

Data are expressed as means \pm SEM. Intergroup differences were evaluated with a non-parametric Mann-Whitney test with a Bonferroni correction for multiple group comparison. The Bonferroni procedure corrects the $\mathrm{p}$ value for each pairwise group comparison, thus with 4 pairwise comparisons $(\mathrm{SH}-\mathrm{NaCl}$ versus $\mathrm{MI}-\mathrm{NaCl}$, $\mathrm{SH}-\mathrm{NaCl}$ versus SH-ANG, MI-NaCl versus $\mathrm{MI}-\mathrm{ANG}$ and SH-ANG versus MIANG), statistical significance is defined as $p<0.0125$ ( $p<0.05$ divided by 4). For the evaluation of systolic blood pressure measurements during the experimental period, areas under the curve were determined and used for subsequent MannWhitney test procedure. 
Table 3.2

General characteristics and blood pressure measurements in experiment 2 and 3

\begin{tabular}{|c|c|c|c|c|}
\hline \multirow[b]{2}{*}{ Variable } & \multicolumn{2}{|c|}{ Saline infused } & \multicolumn{2}{|c|}{ ANG II infused } \\
\hline & Sham & MI & Sham & MI \\
\hline BW day 14 & $303 \pm 4$ & $295 \pm 6$ & $238 \pm 5^{*}$ & $255 \pm 4 \pi$ \\
\hline Gain of BW (g) & $2 \pm 3$ & $-11 \pm 4$ & $-44 \pm 6^{*}$ & $-28 \pm 3$ \\
\hline$H W(g)$ & $0.96 \pm 0.03$ & $0.96 \pm 0.02$ & $0.93 \pm 0.04$ & $0.96 \pm 0.03$ \\
\hline HW/BW $(\mathrm{g} / \mathrm{kg})$ & $3.2 \pm 0.1$ & $3.2 \pm 0.1$ & $3.9 \pm 0.1^{*}$ & $3.8 \pm 0.1 \dagger$ \\
\hline LW/BW $(\mathrm{g} / \mathrm{kg})$ & $4.6 \pm 0.2$ & $5.9 \pm 0.6^{*}$ & $5.6 \pm 0.2^{*}$ & $9.1 \pm 0.8 \dagger$ \\
\hline Infarct size $(\%)$ & & $42 \pm 3$ & & $46 \pm 2$ \\
\hline MAP $(\mathrm{mm} H \mathrm{H})$ & $129 \pm 5$ & $104 \pm 3^{*}$ & $189 \pm 5^{*}$ & $126 \pm 4 t$ \\
\hline HR (beats/min) & $333 \pm 22$ & $345 \pm 14$ & $382 \pm 10$ & $353 \pm 8$ \\
\hline$n$ & 23 & 19 & 20 & 23 \\
\hline
\end{tabular}

Table shows gain of body weights (BW) in 14 days, heart weight (HW), heart-to- bady weight ratios (HW/BW), lung-to-body weight ratios (LW/BW), infarct size, heart rates (HR) and mean arterial pressures (MAP). Data are expressed as mean \pm sem. Statistical analysis: Intergroup differences were tested by Mann-Whitney test with a Bonferroni correction for multiple group comparison; $" p<0.0125$ compared to saline infused sham rats, $\dagger p<0.0125$ compared to saline infused $M I$ rats and $\neq p<0.0125$ compared to $A N G$ II infused sham rats.

\section{Results}

Effect of a myocardial infarction (SH-NaCl versus MI-NaCl):

Ligation of the LAD resulted in an infarction of approximately $45 \%$ of left ventricular circumference. Infarct sizes were comparable in all experiments (tables 3.1 and 3.2). Body weights at day 0 were comparable in all groups. Induction of a Ml decreased body weight in saline infused rats (table 3.1 and 3.2 ). Of note, the weight loss of saline infused rats in experiment 1 (measurement of cardiac function, see table 3.1) was more excessive compared to rats used in experiment 2 and 3 (table 3.2), presumably due to intensive operation procedures. There were no differences in absolute heart weight or heart-tobodyweight ratios between saline infused sham and $\mathrm{MI}$ rats (table 3.1 and 3.2 ). Lung-to-body-weight ratio increased in the MI rats (table 3.2).

The measurements of cardiac function in experiment 1 demonstrated that Ml induction resulted in a decrease in baseline and maximal cardiac index, stroke volume index (figure 3.2) and baseline stroke work (table 3.1). Total peripheral 

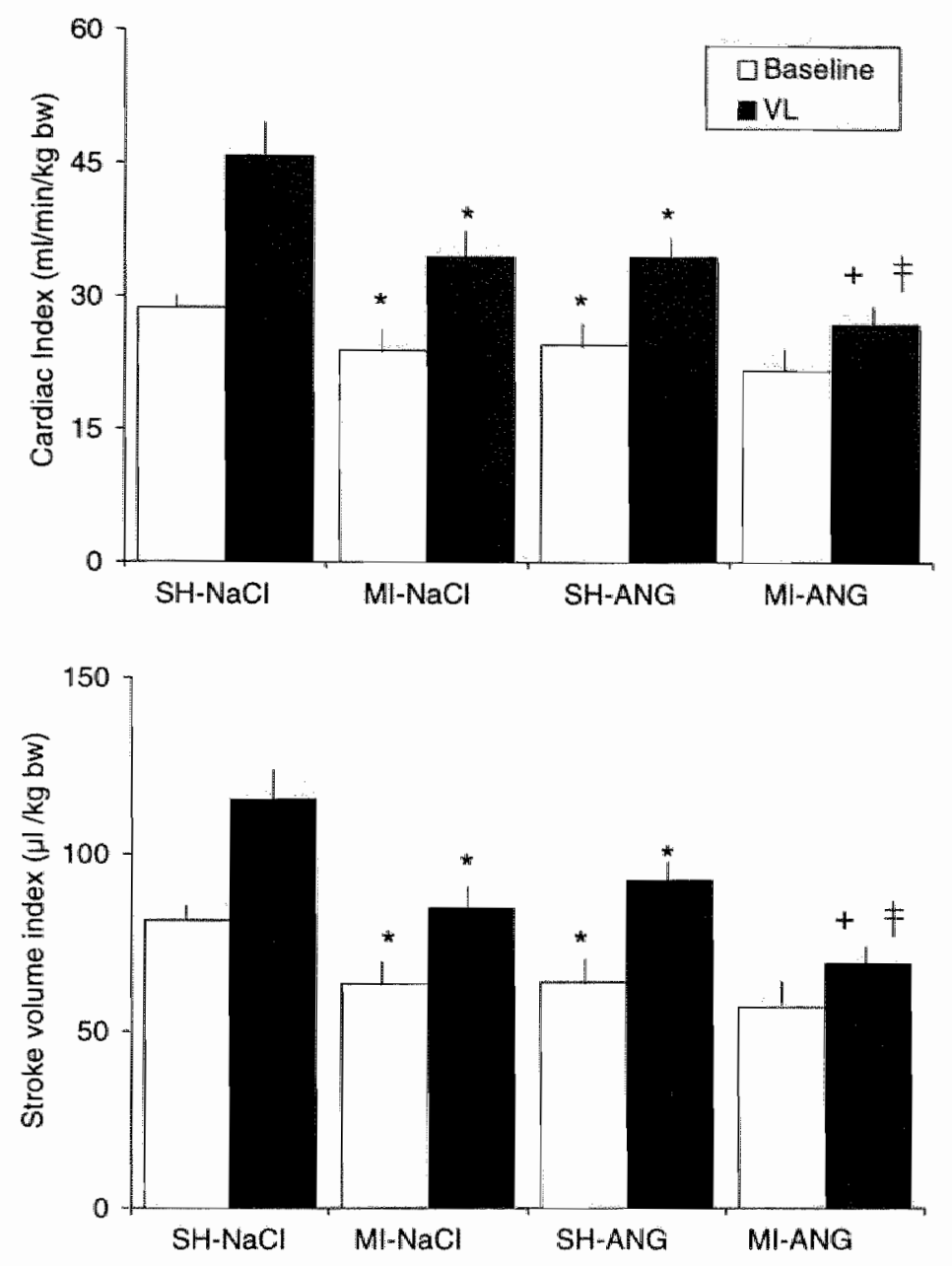

Figure 3.2 Graph showing the effects of saline and ANG II infusions on cardiac index (top panel, $\mathrm{ml} / \mathrm{min} / \mathrm{kg}$ body weight) and stroke volume index (bottom panel, $\mu / 1 / \mathrm{kg}$ body weight) at baseline and during rapid volume loading (VL) in sham and $M$ rats. * $\mathrm{p}<0.0125$ compared to $\mathrm{SH}-\mathrm{NaCl}_{1}+\mathrm{p}<0.0125$ compared to $\mathrm{MI}-\mathrm{NaCl},+$ $\mathrm{p}<0.0125$ compared to SH-ANG by Mann-Whitney test with Bonferroni correction.

resistance and central venous pressure did not change in $\mathrm{Ml}-\mathrm{NaCl}$ rats (table 3.1).

Systolic blood pressures, measured in experiment 2, were comparable at day 0 in all groups. Although at the end of the experimental period systolic blood 


\section{Systolic Blood Pressure}

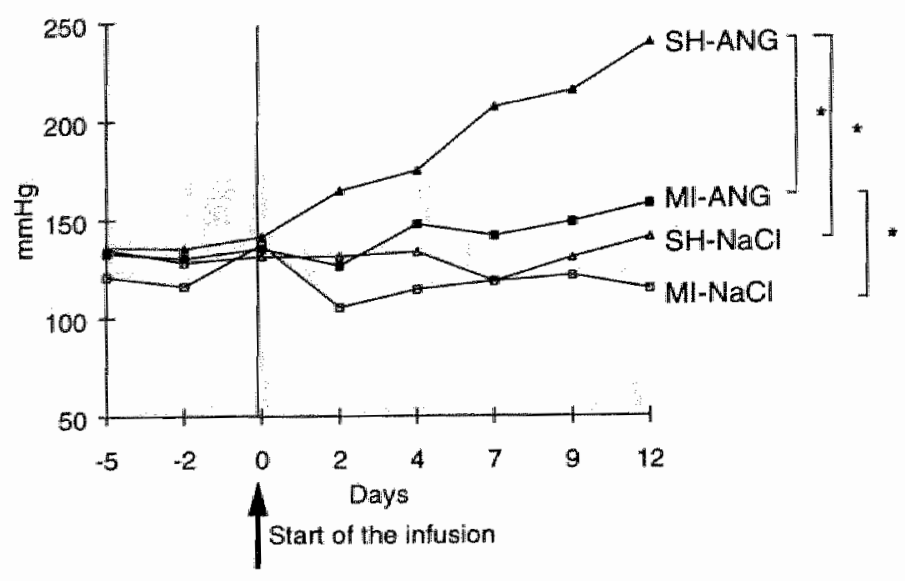

Figure 3.3 Graph showing the effects of a saline or ANG II infusion on systolic blood pressure $(\mathrm{mmHg})$ in sham and $\mathrm{Ml}$ rats. * $p<0.0125$ by Mann-Whitney with Bonferroni correction.

pressures had decreased by $25 \mathrm{mmHg}$ in $\mathrm{MI}-\mathrm{NaCl}$ rats compared to $\mathrm{SH}-\mathrm{NaCl}$ rats (figure 3.3), this did not reach statistical significance $(p=0.04)$. However, direct intra-arterial mean arterial blood pressure measurement on day 14 demonstrated a significant difference between saline infused sham and MI rats (tables 3.2). No differences between saline infused sham and $\mathrm{MI}$ rats were found in the cumulative ANG II pressor response curve as presented in table 3.3.

The vessel dimensions of the superior mesenteric artery, mesenteric and pulmonary resistance arteries are presented in table 3.4 and 3.5. Compared to $\mathrm{SH}-\mathrm{NaCl}$ rats, $\mathrm{Ml}$ induced no changes in vessel dimensions of these three arteries.

Finally, plasma ANP concentrations were increased in saline infused MI rats, while plasma ANG I| concentrations did not differ between groups. Also, aortic cGMP concentrations did not differ between the two groups (experiment 3, table $3.6)$.

Effect of ANG II infusion in sham-operated rats (SH-NaCl versus SH-ANG)

ANG II infusion in sham rats resulted in a substantial weight loss (table 3.1 and 3.2). Although heart weight did not differ between the groups, ANG II infusion increases heart-to-body-weight ratios in SH-ANG rats. There was no evidence of cardiac oederna, as mass fraction of water was comparable in all groups $(\mathrm{SH}-$ 


\begin{tabular}{|c|c|c|c|c|}
\hline \multirow[b]{2}{*}{ Variable } & \multicolumn{2}{|c|}{ Saline infused } & \multicolumn{2}{|c|}{ ANG II infused } \\
\hline & Sham & MI & Sham & MI \\
\hline $\begin{array}{l}\mathrm{ED}_{50} \text { for } A N G \text { II } \\
(\mu \mathrm{g} / \mathrm{kg})\end{array}$ & $0.39 \pm 0.09$ & $0.48 \pm 0.05$ & $0.30 \pm 0.09$ & $0.46 \pm 0.07$ \\
\hline $\begin{array}{l}\text { Peak pressor } \\
\text { response to ANG } 11(\mathrm{~mm}\end{array}$ & $\begin{array}{l}+71 \pm 6 \\
-(g)\end{array}$ & $+59 \pm 5$ & $+94 \pm 9$ & $+74 \pm 10$ \\
\hline $\mathrm{n}$ & 7 & 7 & 6 & 6 \\
\hline
\end{tabular}

Table shows characteristics of the acute ANG II pressor response curve. Data are expressed as mean \pm sem. Statistical analysis: Intergroup differences were tested by Mann-Whitney test with a Bonferroni correction for multiple group comparison; "p<0.0125 compared to saline infused sham rats, $\dagger p<0.0125$ compared to saline infused MI rats and $\neq p<0.0125$ compared to ANG II infused sham rats.

$\mathrm{NaCl} 76 \pm 2 \%$, data of other groups not shown). Lung-to-body weight ratio increased during ANG II infusion in sham rats (table 3.2).

Compared to $\mathrm{SH}-\mathrm{NaCl}$ rats, ANG II infusions in sham rats decreased both baseline and maximal cardiac index and stroke volume index (experiment 1 , figure 3.2). Stroke work, however, did not change. Total peripheral resistance significantly increased in these rats, accounting for the increase in mean arterial pressure (table 3.1).

ANG || treatment gradually increased systolic blood pressures in SH-ANG rats by approximately $70 \mathrm{mmHg}$ at day 12 (experiment 2, figure 3.3). The same increase was seen in mean arterial pressures, measured at day 14 (table 3.1 and 3.2). Characteristics for the acute ANG II dose-blood pressure responses were comparable in ANG $\|$ and saline infused sham rats (table 3.3).

ANG II infusion resulted in $33 \%$ increase in medial cross-sectional area of the superior mesenteric artery in sham-operated rats (table 3.4). Vessel dimensions of both mesenteric and pulmonary resistance arteries were similar in saline and ANG II infused sham-operated rats.

ANG II infusion increased plasma ANG II and ANP in sham rats (experiment 3, table 3.6). Aortic cGMP concentrations tended to decrease from $559 \pm 87$ to $306 \pm 59 \mathrm{fmol} / \mathrm{mg}$ protein in $\mathrm{SH}-\mathrm{NaCl}$ and SH-ANG rats $(p=0.02)$, respectively (table 3.6 ).

Effect of ANG II in myocardial infarcted rats (MI-NaCl versus MI-ANG)

ANG II infusion in $M \mid$ rats resulted in a substantial weight loss (table 3.2). Similar to SH-ANG rats, absolute heart weights of ANG II infused MI rats were 


\begin{tabular}{|c|c|c|c|c|}
\hline & \multicolumn{2}{|c|}{ Saline infused } & \multicolumn{2}{|c|}{ ANG II infused } \\
\hline & Sham & MI & Sham & MI \\
\hline $\begin{array}{l}\text { Medial cross } \\
\text {-sectional area }\end{array}$ & $0.15 \pm 0.01$ & $0.14 \pm 0.02$ & $0.20 \pm 0.01 *$ & $0.14 \pm 0.01$ \\
\hline Lumen area & $0.29 \pm 0.03$ & $0.25 \pm 0.06$ & $0.34 \pm 0.02$ & $0.28 \pm 0.02$ \\
\hline $\begin{array}{l}\text { Media-to- } \\
\text { lumen ratio }\end{array}$ & $54 \pm 6$ & $44 \pm 5$ & $59 \pm 2$ & $50 \pm 4$ \\
\hline $\mathrm{n}$ & 9 & 7 & 14 & 16 \\
\hline
\end{tabular}

Table shows cross-sectional area $\left(\mathrm{mm}^{2}\right)$, lumen area $\left(\mathrm{mm}^{2}\right)$ and media-to-lumen ratio (crosssectional area/lumen area* 100 ) of superior mesenteric artery. Data are expressed as mean \# sem. Statistical analysis: Intergroup differences were tested by Mann-Whitney test with a Bonferroni correction for multiple group comparison; " $p<0.0125$ compared to saline infused sham rats, $t p<0.0125$ compared to saline infused $M I$ rats and $\neq p<0.0125$ compared to ANG II infused sham rats.

comparable to saline infused MI rats, while heart-to-body-weight ratios of ANG II infused MI rats were increased (table 3.1 and 3.2). ANG II infusions in MI rats increased lung-to-body weight ratios.

Cardiac function measurements (experiment 1) demonstrated that baseline cardiac index of ANG II infused MI rats was not different from SH-ANG rats and also not from $\mathrm{Ml}-\mathrm{NaCl}$ rats (figure 3.2). Stroke work was reduced compared to SH-ANG, but not different from $\mathrm{MI}-\mathrm{NaCl}$ (table 3.1). Cardiac index and stroke volume index during volume loading of MI-ANG rats were significantly reduced compared to SH-ANG rats, but not different from $\mathrm{MI}-\mathrm{NaCl}$ rats (figure 3.2). Thus, while ANG II infusion in sham rats significantly reduced cardiac function compared to saline infused sham rats, infusion of ANG II in MI rats did not further reduce cardiac function. This is illustrated by calculations of the relative decrease of cardiac index during volume loading. Thus, cardiac index during volume loading of ANG II infused MI rats decreased $22 \pm 7 \%$ compared to SH-ANG and $22 \pm 7 \%$ compared to $\mathrm{Ml}-\mathrm{NaCl}$ rats. This decrease in cardiac function was fully comparable to the decrease of $25 \pm 4 \%$ in cardiac index during volume loading in $\mathrm{SH}-\mathrm{ANG}$ rats compared to $\mathrm{SH}-\mathrm{NaCl}$ rats. Total peripheral resistance increased by $62 \pm 15 \%$ in M1-ANG rats and by $146 \pm 24 \%$ in SH-ANG rats $(p<0.001)$. Absolute values, however, were comparable in both groups (table 3.1).

Despite comparable effects on cardiac function, infusion of ANG Ili in a dose 

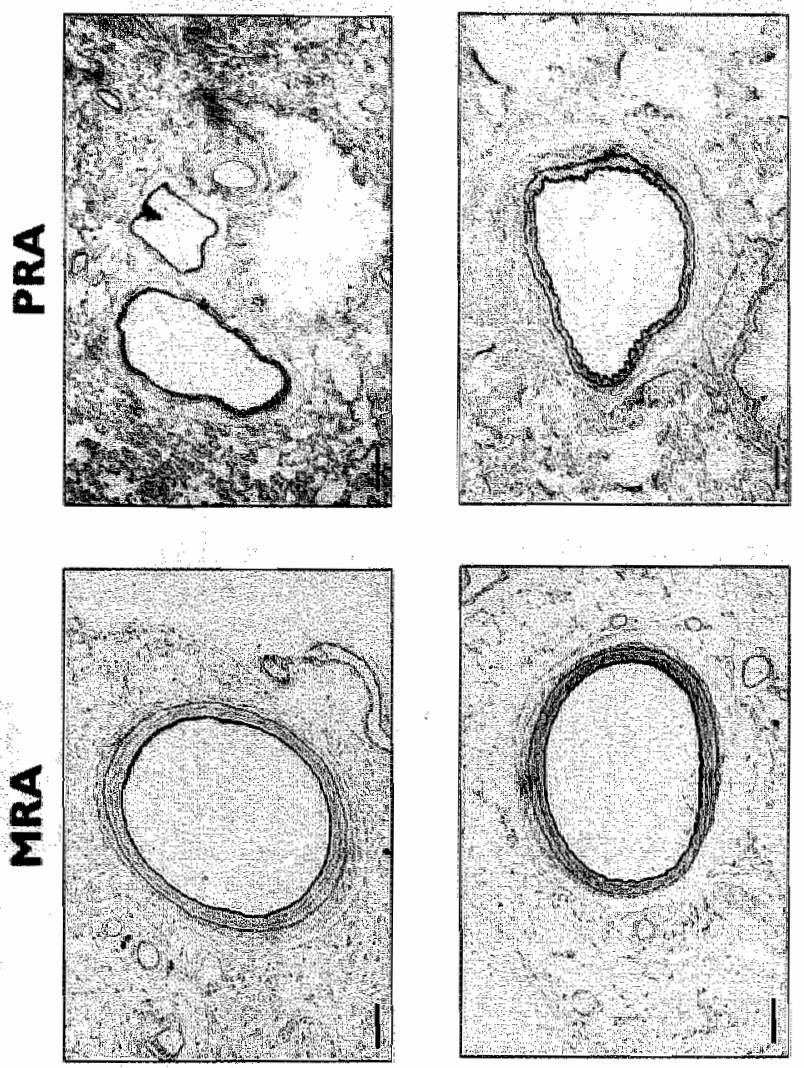

웅

क

응 의 눈

홍

क 20

蚝

틍

$=0$

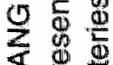

एक

蓶 $\frac{8}{8}$

$\$$ का

은

क⿺

응 은

为至

密

융

is

원 흠 둠

짛

है.

동

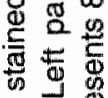

的宁迹

30

要
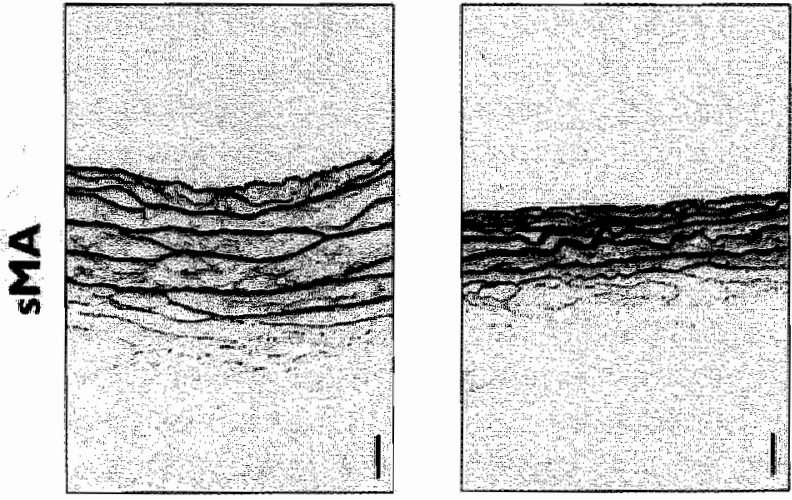

枵此

$8 \geq$

을 음

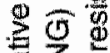

Q 20

要站

는 $\frac{1}{0}$

号

$\frac{\frac{9}{4}}{\frac{4}{2}}$

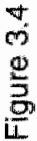


Table 3.5 Vessel dimensions of resistance arteries

\begin{tabular}{|c|c|c|c|c|}
\hline & \multicolumn{2}{|l|}{ Saline infused } & \multicolumn{2}{|l|}{ ANG II infused } \\
\hline & Sham & $M \|$ & Sham & MI \\
\hline \multicolumn{5}{|c|}{ Medial cross-sectional area } \\
\hline $\begin{array}{l}\text { mRA } \\
\text { pRA }\end{array}$ & $\begin{array}{l}22366 \pm 2623 \\
31483 \pm 2319\end{array}$ & $\begin{array}{l}23737 \pm 2942 \\
35041 \pm 2023\end{array}$ & $\begin{array}{l}25143 \pm 1787 \\
29403 \pm 2115\end{array}$ & $\begin{array}{l}22629 \pm 1916 \\
39665 \pm 3192\end{array}$ \\
\hline $\begin{array}{l}\text { Lume } \\
\text { mRA } \\
\text { pRA }\end{array}$ & $\begin{array}{l}27679 \pm 7318 \\
64826 \pm 7970\end{array}$ & $\begin{array}{l}35072 \pm 8167 \\
67608 \pm 3555\end{array}$ & $\begin{array}{l}27511 \pm 4772 \\
69210 \pm 7398\end{array}$ & $\begin{array}{l}30555 \pm 5793 \\
76431 \pm 5274\end{array}$ \\
\hline $\begin{array}{l}\text { Media } \\
\text { mRA } \\
\text { pRA }\end{array}$ & $\begin{array}{l}\text { n ratio } \\
78 \pm 13 \\
60 \pm 9\end{array}$ & $\begin{array}{l}53 \pm 9 \\
57 \pm 6\end{array}$ & $\begin{array}{l}97 \pm 11 \\
51 \pm 6\end{array}$ & $\begin{array}{l}75 \pm 11 \\
57 \pm 7\end{array}$ \\
\hline$n$ & 9 & 7 & 14 & 16 \\
\hline
\end{tabular}

Table shows cross-sectional areas, lumen areas (both in $\mu \mathrm{m}^{2}$ ) and media-to-lumen ratio (cross-sectional area/lumen area * 100) of the mesenteric and pulmonary resistance arteries (mRA and PRA, respectively). Data are expressed as mean \pm sem. Statistical analysis: Intergroup differences were tested by Mann-Whitney test with a Bonferroni correction for multiple group comparison; " $p<0.0125$ compared to saline infused sham rats, $t p<0.0125$ compared to saline infused MI rats and $\neq p<0.0125$ compared to ANG II infused sham rats.

that increased systolic blood pressures in ANG II infused sham rats, resulted in a much smaller increase of $30 \mathrm{mmHg}$ in $\mathrm{Ml}$ rats (experiment 2, figure 3.3). In fact, blood pressures in ANG II infused $\mathrm{MI}$ rats were not different from $\mathrm{SH}-\mathrm{NaCl}$ rats during the entire experimental period. The same pattern of changes was seen in mean arterial pressures of the rats used in both experiment 1 and 2 , measured at day 14. While ANG $\|$ infusion in sham rats increased mean arterial pressure by approximately $60 \mathrm{mmHg}$ as compared to $\mathrm{SH}-\mathrm{NaCl}$ rats (relative increase of $47 \pm 5 \%$ ), mean arterial pressure in MI-ANG rats was only $20 \mathrm{mmHg}$ higher than in $\mathrm{MI}-\mathrm{NaCl}$ rats (relative increase of $21 \pm 4 \%$ ) and not different from $\mathrm{SH}-\mathrm{NaCl}$ rats (table 3.2). ANG II infusion in Ml rats, in contrast to its infusion in sham rats, did not increase medial cross-sectional area of the superior mesenteric artery (figure 3.4 and table 3.4). Furthermore, the ANG II infusion tended to increase medial cross-sectional area of the pulmonary resistance arteries, but this was not statistical significant $(p=0.06$, table 3.5$)$.

ANG $\|$ infusion in MI rats increased plasma concentrations of ANG $\|$ and ANP (experiment 3, table 3.6). Plasma ANG II concentrations did not differ in MlANG and SH-ANG rats. Plasma ANP levels showed a clear tendency to increase in Ml-ANG rats (SH-ANG $58 \pm 13 \mathrm{pg} / \mathrm{ml}$ and Ml-ANG 152 $\pm 48, \mathrm{p}=0.07$ ). ANG ॥ 
Table 3.6

Plasma ANG II and ANP concentrations and aortic cGMP concentrations.

\begin{tabular}{|c|c|c|c|c|}
\hline \multirow[b]{2}{*}{ Variable } & \multicolumn{2}{|c|}{ Saline infused } & \multicolumn{2}{|c|}{ ANG II infused } \\
\hline & Sham & MI & Sham & MI \\
\hline Plasma ANG II & $22 \pm 4$ & $22 \pm 6$ & $84 \pm 21^{*}$ & $75 \pm 23 \dagger$ \\
\hline Plasma ANP & $21 \pm 1$ & $42 \pm 10^{*}$ & $58 \pm 13^{*}$ & $152 \pm 48 t$ \\
\hline Aortic cGMP & $559 \pm 87$ & $422 \pm 72$ & $306 \pm 59$ & $635 \pm 106 \ddagger$ \\
\hline$n$ & 14 & 12 & 6 & 7 \\
\hline
\end{tabular}

Table shows plasma concentrations of ANG II $(\mathrm{pg} / \mathrm{ml})$ and atrial natriuretic peptide (ANP, $\mathrm{pg} / \mathrm{ml}$ ) and aortic cGMP concentrations (fmol/mg protein). Statistical analysis: Intergroup differences were tested by Mann-Whitney test with a Bonferroni correction for multiple group comparison; " $p<0.0125$ compared to saline infused sham rats, $t p<0.0125$ compared to saline infused MI rats and $\neq p<0.0125$ compared to ANG II infused sham rats.

infusions in MI rats tended to increase cGMP concentrations in ANG II infused MI rats (from $422 \pm 72$ to $635 \pm 106 \mathrm{fmol} / \mathrm{mg}$ protein, $p=0.15$ ). As a result of the decrease in cGMP concentrations in SH-ANG rats, aortic cGMP concentrations significantly increased in ANG II infused MI rats, compared to SH-ANG (table 3.6).

\section{Discussion}

The results of the present study indicate that infusion of ANG I| decreased cardiac function in both sham and $M I$ rats. Thus, although an increased plasma ANG II concentration is correlated with a poor prognosis in humans $(5,6)$, it did not result in the expected adverse effects on cardiac function in MI rats. Other expected findings of the exogenous ANG II infusion, i.e. increased mean arterial blood pressure and hypertrophy of the peripheral vascular wall, were also not observed in $\mathrm{Ml}$ rats. The data further suggests that during infusion of ANG II in compensated heart failure, other hormonal systems are activated and suppress the hypertensive and hypertrophic effects of ANG II.

Infusion of ANG II in experimental animals is known to reduce cardiac output $(14,15)$. This is confirmed in the present study as ANG II infusion reduced cardiac function in sham rats. However, in the ANG II infused MI rats, the reduction of baseline cardiac index and stroke volume index were not different from those observed in SH-ANG rats and, more importantly, not different from MI- 
$\mathrm{NaCl}$ rats. As outlined in the results section, relative reductions in indexes during volume loading of $\mathrm{MI}-\mathrm{ANG}$ rats were comparable to relative reductions observed in ANG II infused sham rats. Also, MI-ANG animals were able to generate a peak pressor response following injections of ANG II comparable to SH-ANG (table 3.3, $\mathrm{Mi}-\mathrm{NaCl}+59 \pm 5 \mathrm{mmHg}$. MI-ANG $+74 \pm 10 \mathrm{mmHg}, \mathrm{p}=\mathrm{NS}$ ), indicating that combination of myocardial infarction and ANG II infusion did not result in a further deterioration of cardiac function. Finally, absolute values of total peripheral resistance did not differ in ANG II infused sham and MI rats, indicating that ANG II infusions did result in similar increases in total peripheral resistance in MI and sham rats.

ANG II infusion had comparable negative effects on cardiac function in rats with and without MI. In ANG II infused MI rats, however, it did not result in the large increase in blood pressure as seen in ANG II infused sham rats nor did it induce the typical hypertrophic response of the vascular wall of large conduit arteries.

At least three phenomena may be responsible for suppression of pressor and structural vascular effects of ANG II in Mi rats. Firstly, ANG II may deteriorate cardiac function in MI rats, which did not occur. Secondly, different ANG-receptor subtypes may be involved in the acute and long-term hypertensive and hypertrophic actions of the peptide. The aortic wall of a normal adult rat contains the angiotensin subtype 1 (AT1) and subtype 2 (AT2) receptor subtype in a $4: 1$ ratio (16). AT1 receptors mediate vasoconstriction and vascular smooth muscle cell growth (17). AT2 receptors are thought to have a functional role during embryonal development (18) and may mediate antiproliferative and apoptotic effects $(19,20)$. The subtypes may differ in the extent to which they are regulated by elevated levels of the agonist (17) and a switch from the AT1 to the AT2 receptor in peripheral arteries of MI rats might explain the suppression of pressor and structural effects of ANG II infusions. In the heart, a change in expression of AT1 and AT2 receptors has been shown to occur during heart failure (21-23). In the present study, however, both $\mathrm{ED}_{50}$ and maximal elevation of pressure following acute injections of ANG II, were not affected in ANG 11 infused MI rats, indicating the presence of functionally active vascular AT1 receptors after a two week ANG II infusion. A possible upregulation of AT2 receptors, however, cannot be excluded.

Another possibility is that in MI rats the pressor and mitogenic effects of ANG Il may have been counteracted by a concomitant activation of other neurohumoral systems. Candidate vasodilating and vascular smooth muscle cell growth suppressor systems are ANP and NO, which have increased plasma levels during heart failure $(24,25)$. In cultured vascular smooth muscle cells, both ANP and NO have antimitogenic effects $(26,27)$. In vivo, infusions of non-depressor doses of ANP decrease medial thickness in spontaneously hypertensive rats (28), while inhalation of NO inhibits neointimal formation after balloon-induced arterial injury 
(29). In our experimental model of heart failure, ANG II infusion tended to increase plasma ANP concentrations. Moreover, although ANG II had divergent effects on aortic cGMP concentrations (i.e. tendency to decrease in SH-ANG rats and to increase in MI-ANG rats), aortic cGMP concentrations were significantly higher in ANG II infused MI rats, compared to ANG II infused sham rats. The in vivo basal aortic cGMP concentration seems to mainly depend an NO synthase (30), since contribution of endogenous ANP to basal aortic cGMP generation, via stimulation of the particulate guanylate cyclase, appears to be minor compared to that of NO via soluble guanylate cyclase. Thus, it is attractive to hypothesize that during infusion of ANG II in experimental heart failure, the growth-stimulatory and hypertensive effects of ANG $\|$ are counteracted by concomitant activation of vasodilating and growth-inhibitory systems, such as ANP and NO.

It should be noted that the lack of hypertrophic response of the superior mesenteric artery in $\mathrm{Ml}$ rats may also be explained by the normal, non hypertensive blood pressures after two weeks of ANG II infusions. However, infusion of ANG II in normal rats induces a hypertrophic response in peripheral vessels $(11,31)$, and this effect has been shown to be independent of the increase in blood pressure (32). Also, ANG II has growth-stimulating effects for vascular smooth muscle cells in culture $(31,33)$. Thus, we assume that the dose of ANG II given in this study was high enough to potentially induce a hypertrophic vascular response, and that this effect is independent from blood pressure.

A different response to ANG II was seen in the resistance arteries. MI alone or in combination with ANG II infusion did not induce changes in dimensions of the mesenteric resistance arteries. ANG II has been shown to have different effects on large conduit arteries and resistance arterioles (reviewed in 34 and 35). While the increase in wall thickness in large vessels is the result of hypertrophy, changes in wall thickness in small vessels appear to result from hyperplasia. Also, ANG II has been shown to induce increases in vessel wall thickness in the mesenteric circulation of young and adult rats $(32,36)$ at similar infusion rates as the ones used in this study. However, in those studies $(32,36)$, medial thickness was measured after myograph experiments (no in situ fixation) and in smaller branches of the mesenteric circulation (lumen diameter $200 \mu \mathrm{m}$ versus $300 \mu \mathrm{m}$ in the present study), which might explain the differences with results of the present study. Also, mesenteric resistance arteries have been reported to have only weak contractions to ANG II (compared to e.g. femoral resistance arteries (37)). It is also possible that, in this study, the time span was too short to induce hyperplastic changes in mesenteric resistance arteries.

Next to its effects on peripheral vascular structure, ANG II also increased heart-to-body weight ratio. Many studies have shown a development of cardiac hypertrophy during chronic ANG $\|$ infusions $(38,39)$. Most studies define 'cardiac hypertrophy' as an increase in heart-to-body weight ratio"s. According to this definition, infused $\mathrm{Ml}$ and sham rats in the present study would also display 
cardiac hypertrophy. However, given the fact that the absolute heart weights did not differ, and as the animals lost a significant amount of body weight, the heartto-body weight ratio does not give a fair representation of the amount of cardiac hypertrophy. Thus, in the present study, a two week ANG II infusion of 250 $\mathrm{ng} / \mathrm{kg} / \mathrm{min}$ did not result in the development of a pronounced cardiac hypertrophy.

In conclusion, this study shows that elevation of plasma ANG II infusion 2 weeks after infarction results in a comparable reduction of cardiac function in both sham and MI rats. Interestingly, in contrast to ANG II infused sham rats, ANG II infused MI rats do not develop hypertension or structural vascular alterations. We suggest that the reason for this divergent response in sham and $M I$ rats is the activation of counterregulatory hormonal systems in $\mathrm{Ml}$ rats, which are, at least in the compensated phase of heart failure, responsible for suppression of the hypertensive and hypertrophic effects of ANG II. This suggests that adverse effects of ANG II on function and structure of the cardiovascular system become evident only when counter-regulatory hormonal systems are failing, as in decompensated heart failure. 


\section{References}

1. Paul $M$, Pinto $Y M$, Schunkert $H$, Ganten $D$, Böhm M. Activation of the renin-angiotensin system in heart failure and hyper. trophy. Studies in human hearts and transgenic rats. Eur Heart $J$ 1994;15:6367.

2. McAlpine HM, Morton JJ, Leckie B, Rum-

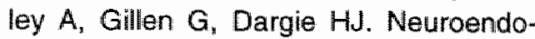
crine activation after acute myocardial infarction. Br Heart J 1988;60:117-124.

3. Hirsch AT, Pinto YM, Schunkert H, Dzau VJ. Potential role of the tissue renin-angiotensin system in the pathophysiology of congestive heart failure. Am J Cardiol 1990;66:22D-32D.

4. Dzau VJ, Coluccil WS, Hollenberg NK, Williams $\mathrm{GH}$. Relation of the reninangiotensin-aldosteron system to clinical state in congestive heart failure. Circulation $1981 ; 63: 645-651$.

5. Francis GS, Cohn $\mathrm{JN}_{\text {" Johnson }} \mathrm{G}$, Rector TS, Goldman S, Simon A. Plasma norepinephrine, plasma renin activity and congestive heart failure. Relations to survival and the effects of therapy in V-HeFT II. Circulation 1993;87:V/40-V/48.

6. Swedberg $K$, Eneroth $P$, Kjekshus $d$, Wilhelmsen $L$. Hormones regulating cardiovascular function in patients with severe congestive heart failure and their relation to mortality. Circulation 1990; 82:1730-1736.

7. Schoemaker RG, Debets $\mathcal{J}_{n}$ StruykerBoudier HA, Smits JF. Two weeks of intermittent dobutamine therapy restores cardiac performance and inotropic responsiveness in conscious rats with heart failure. I Cardiovasc Pharmacol 1991;17:949-956.

8. Schoemaker RG, Debets JJM, Struyker Boedier HAJ, Smits JFM. Two weeks of intermittent dobutamine therapy restores cardiac performence and inotropic responsiveness in conscious rats with heart failure. I Cardiovasc Phamacol $1991 ; 17: 949-956$.

9. Yamagishi $H_{4}$ Kim $S$, Nishikimi $T_{3}$ Takeuchi $K_{s}$ Takeda $T$. Contribution of cardiac renin-angiotensin system to ventricular remodeling in myocardial-infarcted rats. I Mol Cell Cardiol 1993;25:1369-1380.

10. Heeneman $S_{i}$ Leenders PJA, Aalts PLJW, Smits JFM, Arends JW, Daemen MJAP. Peripheral vascular alterations during experimental heart failure. Do they exist? Arteriosel Thromb Vasc Biol 1995; 15:1503-1511.

11. Daemen MJ, Lombardi DM, Bosman FT. Schwartz SM. Angiotensin II induces smooth muscle cell proliferation in the normal and injured rat arterial wall. Circ Res 1991;68:450-456.

12. Fishbein MC, Maciean $D_{*}$ Maroko PR. Experimental myocardial infarction in the rat. Am J Pathol 1978:90:57-70.

13. Steiner AL, Pagliara AS, Chase LR, Kipnis DM. Radioimmunoassay for cyclic nucleotides. J Biol Chem 1972;247:11141120.

14. Cargill RI, Coutie Wd, Lipworth BJ. The effects of angiotensin II on circulating levels of natriuretic peptides. $\mathrm{Br} / \mathrm{Clin}$ Pharmacol 1994:38:139-142.

15. Cheng $C P$, Suzuki $M$, Ohte $N$, Ohro $M$, Wang ZM, Little WC. Altered ventricular and myocyte response to angiotensin $\mathrm{Ill}$ in pacing-induced heart failure. Circ Res 1996; 78:880-892.

16. Viswanathan $M$, Stromberg $C$, Seltzer $A$, Saavedra JMM. Balloon angioplasty enhances the expression of angiotensin-11 AT1 receptors in neointima of rat aorta. $d$ Clin Invest 1992;90:1707-1712.

17. Timmermans PBMWM, Wong PC, Chiu AT, Herblin WF, Benfield P, Carini DJ, Lee RJ, Wrexter RR, Saye JAM" Smith 
AD. Angiotensin II receptors and angiotensin II receptor antagonists. Pharm Rev 1993:45:205-251.

18. Viswanathan $M$, Tsutsumi $K$, Correa FMA, Saavedra JM. Changes in expression of angiotensin receptor subtypes in the rat aorta during development. Biochem Biophys Aes Commun 1991; 179 : $1361-1367$.

49. Stoll $M$, Steckelings $M$, Paul $M$, Bottari $S P$, Metzger $R$, Unger $T$. The angiotensin AT2-receptor mediates inhibition of cell proliferation in coronary endothelial cells. $\checkmark$ Clin Invest 1995;95:651-657.

20. Yamada T, Horiuchi M, Dzau VJ. Angiotensin II type 2 receptor mediates programmed cell death. Proc Natl Acad Sci USA 1996;93:156-160.

21. Nio $Y$, Matsubara $H$, Murasawa $S$, Kanasaki $M_{n}$ Inada $M$. Regulation of gene transcription of angiotensin II receptor subtypes in myocardial infarction. $J$ Clin invest $1995 ; 95: 46-54$.

22. Regitz-Zagrosek $V$. Friedel $N$, Heymann A, Bauer $P$, Neuß $M_{\text {r }}$ Rolfs A, Steffen C, Hildebrandt $A$, Hetzer R, Fleck E. Regulation, chamber localization and subtype distibution of angiotensin II receptors in human hearts. Circulation 1995;91:14611471.

23. Rogg $H$, de Gasparo $M$, Graedel E, Stuiz $P$, Burkant $F$, Eberhard $M_{1}$ Erne P. Angiotensin II-peceptor subtypes in human atria and evidence for alterations in patients with cardiac dysfunction. Eur Heart $J$ $1996 ; 17: 1112-1120$.

24. Svanegaard J, Angelo-Nielsen $K$, Pindborg T. Plasma concentration of atrial natriuretic peptide at admission and risk of cardiac death in patients with acute myocardial infarction. $\mathrm{Br}$ Heart $J 1992$; 68:38-42.

25. Winlaw DS, Smythe GA, Keogh AM, Schyvens CG, Spratt PM, MacDonald PS. Increased nitric oxide production in heart failure. Lancet 1994;344:373-374.

26. Itoh H, Pratt RE, Dzau VJ. Atrial Natriuretic Polypeptide inhibits hypertrophy of vascular smooth muscle cells. J Clin $/ \mathrm{In}$ vest 1990;86:1690-1697.

27. Nunokawa $\gamma$, Tanaka $S$. Interferongamma inhibits proliferation of rat vascular smooth muscle cells by nitric oxide generation. Biochem Biophys Res Commun 1992;188:409-415.

28. Mourlon-le Grand MC, Poitevin P, Benessiano $J$, Duriez $M$, Michel JB, Levy BI. Effect of a nonhypotensive long-term infusion of ANP on the mechanical and structural properties of the arterial wall in Wistar-Kyoto and Spontaneously Hyper. tensive Rats. Arterioscl Thromb Vasc Biol $1993 ; 13: 640-650$.

29. Lee JS, Adrie C, Jacob HJ, Roberts JD, Zapol WM, Bloch KD. Chronic inhalation of nitric oxide inhibits neointimal formation after balloon-induced arterial injury. Circ Res 1996;78:337-342.

30. Arnal JF, Warin L, Michel JB. Determinants of aortic cyclic guanosine monophosphate in hypertension induced by chronic inhibition of nitric oxide synthase. 1 Clin invest 1992;90:647-652.

31. Geisterfer AA, Peach MJ. Owens GK Angiotensin II induces hypertrophy, not hyperplasia, of cultured rat aortic smooth muscle cells. Circ Res 1988;62:749-756.

32. Griffin $S A$, Brown WC, MacPherson $F_{\text {。 }}$ McGrath JC, Wilson $V G$, Korsgaard $N$, Mulvany MJ, Lever AF. Angiotensin II causes vascular hypertrophy in part by a non-presisor mechanism. Hypertension $1991 ; 17: 626-635$.

33. Gibbons GH, Pratt RE, Dzau VJ. Vascular smooth muscle cell hypertrophy vs hy. perplasia - Autocrine transtorming growth factor-betal expression determines growth response to angiotensin-11. $J$ Clin Invest 1992;90;456 461. 
34. Heagerty AM, Aalkjaer C, Bund SJ, Kors-

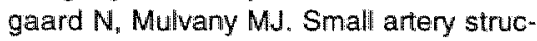
ture in hypertension - Dual processes of remodeling and growth. Hypertension 1993:21:391-397.

35. Mulvany MJ. Resistance vessel structure and the pathogenesis of hypertension. $J$ Hypertens 1993:11:S7-S12.

36. Boonen HCM, Daemen MJAP, Eerdmans PHA, Fazzi GE van Kleef EM, Schiffers $\mathrm{PMH}_{\mathrm{x}}$ De Mey JGR. Mesenteric small artery changes after vasoconstrictor infusion in young rats. I Cardiovasc Pharmacol 1993;22:388-395.

37. Juul B, Aalkjaer C, Mulvany MJ. Responses of femoral resistance arteries to angiotensin in vitro. Eur J Pharmacol 1987; 135:61-68.

38. Dostal DE, Baker KM. Angiotensin II stimulation of left ventricular hypertrophy in adult rat heart. Am $\mathrm{I}$ Hypertens 1992; 5:276-280.

39. Kim $S$, Ohta $K_{1}$ Hamaguchi $A$, Yukimura $T$. Miura $K$, Iwao $H$. Angiotensin II induced cardiac phenotypic modulation and remodeling in vivo in rats. Hypertension $1995 ; 25: 1252-1259$. 


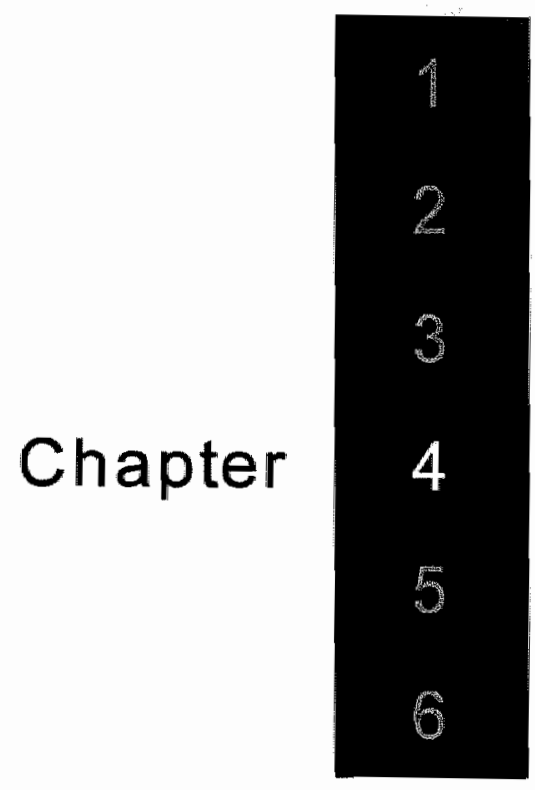

Opposing Effects of Angiotensin type 1 and type 2 receptor on Blood Pressure and Peripheral Vascular Structure in Rats with a Myocardial Infarction

Sylvia Heeneman, Jos Smits, Peter Leenders, Mat Daemen

Submitted for publication 


\begin{abstract}
In this study, a model for compensated heart failure with increased plasma concentrations of angiotensin II (ANG II) was used to investigate the inwolvement of ANG If receptors (AT) type 1 and 2 in the regulation of blood pressure and peripheral vascular structure. Therefore, ANG II $(250 \mathrm{ng} / \mathrm{kg} / \mathrm{min}$ ) in combination with the AT1 receptor antagonist GA138950 (2 $\mathrm{mg} / \mathrm{kg} /$ day) or the AT2 receptor antagonist PD123319 (10 $\mathrm{mg} / \mathrm{kg} / \mathrm{day}$ ) was infused in myocardial infarcted rats. After two weeks, blood pressure and indices of peripheral vascular structure were measured. Results: ANG II infusion increased mean arterial blood pressure and medial cross-sectional area (CSA) of several large conduit arteries in shamoperated rats, but had no effect in $M I$ rats. PD123319 infusion in ANG II infused sham rats did not change mean arterial blood pressure. In ANG II infused MI rats, however, PD123319 did increase blood pressure further, while GR138950 significantly lowered blood pressure. The effects of AT2 receptor antagonism on the structure of peripheral arteries were very heterogeneous. PD123319 increased medial CSA of the thoracic aorta of ANG II infused sham rats, but did not change medial CSA of the superior mesenteric and carotid arteries. It had no major effects on vessel dimensions of the resistance arteries in
\end{abstract}

\begin{abstract}
this group of rats. In ANG II infused MI rats, PD123319 had no effects on vessel dimensions of both large conduit and resistance arteries. Coinfusion of ANG II and GR138950 in MI rats decreased medial CSA of both large conduit and resistance anteries as compared to ANG II (and PD) infused Ml rats. Conclusion: During blockade of the AT1 receptor, ANG II will selectively stimulate the AT2 receptor. Thus, the reduction of both blood pressure and medial CSAs during coinfusion of ANG II and GR138950 suggests that the AT2 receptor opposes the effects of the AT1 receptor in the regulation of blood pressure and vascular structure in $\mathrm{MI}$ rats. Furthermore, the observations that AT2 receptor blockade does increase blood pressure in ANG II infused MI rats, but not in sham rats confirms the conclusion on the role of the AT2 receptor in blood pressure regulation in $\mathrm{MI}$ rats. In contrast to sham rats, AT2 receptor blockade in MI rats does not affect medial CSAs of peripheral arteries. It is hypothesized that these variations in wascular remodeling during AT2 receptor blockade may be explained by either different ratio's of vascular AT1 and AT2 receptors or the involvement of other regulatory mechanisms.
\end{abstract}




\section{Introduction}

The responses of heart and blood vessels to angiotensin II (ANG II) are mediated by two receptor subtypes, the angiotensin type 1 (AT1) and the angiotensin type 2 (AT2) receptor. The AT1 receptor is well-characterized and present in cardiac and vascular tissue. It mediates the effects of ANG || on peripheral vasoconstriction, aldosterone release and cardiac myocyte and vascular smooth muscle cell proliferation (1-4). Much less is known about the function of the AT2 receptor, but the results of recent studies suggest that the AT2 receptor has opposing actions on the blood pressure regulating and growth-stimulating effects of the AT1 receptor $(5,6)$.

During heart failure, the activity of the renin-angiotensin system and plasma concentrations of ANG II have been shown to increase $(7,8)$. In the acute phase, ANG II mediates vasoconstriction and fluid-retention thereby maintaining cardiac output and sustaining organ perfusion. However, despite these beneficial effects, increased plasma concentrations are also correlated with a poor prognosis $(9,10)$. Thus, in view of the important role of ANG II on vascular tone and structure and the opposing actions of the AT2 receptor on the AT1 receptor, the AT2 receptor could be important in determining the effects of ANG II during heart failure. In chapter 3 , it was shown that infusion of exogenous ANG II in sham and $\mathrm{MI}$ rats influenced systemic blood pressure and peripheral vascular structure quite differently. While ANG II increased the blood pressure and induced hypertrophy of the peripheral vascular wall in sham-operated rats, it failed to increase the systemic blood pressure in $\mathrm{MI}$ rats above the normotensive control level and failed to affect peripheral vascular structure. In the present study, the hypothesis was tested that suppression of hypertensive and peripheral hypertrophic effects of ANG II in MI rats, is caused by the effects of the AT2 receptor on blood pressure and peripheral vascular structure. To test this hypothesis, blood pressure and parameters of peripheral vascular structure were measured in $\mathrm{Ml}$ rats that were co-infused with ANG II and either the AT1 receptor antagonist GR138950 or the AT2 receptor antagonist PD123319.

Materials and methods

\section{Animals}

Male Wistar rats ( $\mathrm{n}=57,270-275 \mathrm{~g}$ at day 0 , Iffa Credo, Someren, the Netherlands) were housed under standard conditions and fed standard rat chow (RMH-TM, Hope Farms, Woerden, The Netherlands) and water ad libitum. The experiments were performed in accordance with local institutional guidelines. Of the 57 rats used, 14 died

following coronary artery ligation and none following sham surgery. Five rats had infarct sizes less than $20 \%$ of left ventricular circumference, or showed nontransmural infarcts. 
Rats were randomly assigned to the following groups, SH-ANG $(n=9)$ were subjected to sham surgery and were infused with angiotensin II (ANG II). MI-ANG $(n=10)$ were infused with $A N G$ II following induction of a myocardial infarction (MI). SH-ANG-PD $(n=7)$ and MI-ANG-PD $(n=7)$ were subjected to sham and Ml surgery, respectively; and infused with ANG II and the AT2 receptor antagonist PD123319. MI-ANG-GR $(n=5)$ were subjected to MI surgery and infused with ANG II and the AT1 receptor antagonist GR138950. Sham-operated rats infused with the AT1 antagonist GR138950 were not included, as previous studies in our laboratory showed that combined infusion of ANG II and AT1 blockade did not increase blood pressure (4). Also, the blood-pressure reducing effects of AT1 receptor blockade during infusions of ANG II are well known from literature $(4,11,12)$.

\section{Coronary artery ligation}

Myocardial infarction was induced by ligation of the left anterior descending coronary artery (LAD) according to the method of Fishbein (13) as described in chapter 2.

\section{Drug treatment}

Drugs were infused by minipumps (Alzet model 2002 for ANG II and PD123319 and Alzet $2 \mathrm{ml1}$ for GR138950, Alza Corporation, Palo Alto, California), implanted subcutaneously between the shoulder blades on the day of MI or sham surgery. ANG II (human [ $\mathrm{Val}$ ] ANG II, $250 \mathrm{ng} / \mathrm{kg} / \mathrm{min}$, Brunschwig, Amsterdam, The Netherlands) was dissolved in $0.9 \% \mathrm{NaCl}$. The AT2 receptor antagonist PD123319 $(10 \mathrm{mg} / \mathrm{kg} / \mathrm{day}$, firma) was dissolved in $0.9 \% \mathrm{NaCl}$ and the AT1 receptor antagonist GR138950 ( $2 \mathrm{mg} / \mathrm{kg} /$ day) was dissolved in $0.8 \% \mathrm{NaHCO}_{3}$ and $10 \%$ ethanol. For GR138950, the osmotic minipump was connected to a PE10 catheter, to infuse GR138950 directly into the left jugular vein.

The doses of the two AT receptor antagonist were based on pilot studies. Rats $(n=4-6)$ were infused for two weeks with NaCl, GR138950 and PD123319. At the end of the infusion period, rats were anesthetized with sodium pentobarbital $(60 \mathrm{mg} / \mathrm{kg}$ i.p.) and the ANG II dose-pressor relationship was assessed in a cumulative fashion as described in chapter 3.

GR138950 in a dose of $2 \mathrm{mg} / \mathrm{kg} /$ day was found to induce a 20 -fold right-ward shift of the dose-pressor response to ANG II. PD123319 in a dose of $10 \mathrm{mg} / \mathrm{kg} / \mathrm{day}$ did not influence $E D_{50}$, suggesting a total lack of inhibition of the pressor response to ANG II. Infusion of PD123319 in a dose of $10 \mathrm{mg} / \mathrm{kg} / \mathrm{min}$ in the rat results in plasma concentrations around $300 \mathrm{nM}$ (14). Since the $I_{50}$ of PD123319 for the AT2 receptor is approximately $10 \mathrm{nM}$, this dose of PD123319 should result in an effective AT2 receptor blocking, without affecting the AT1 receptor.

\section{Assessment of mean arterial pressures and heart rates on day 14.}

On day 14 , mean arterial blood pressures and heart rates were measured as described in the materials and methods in chapter 3. 

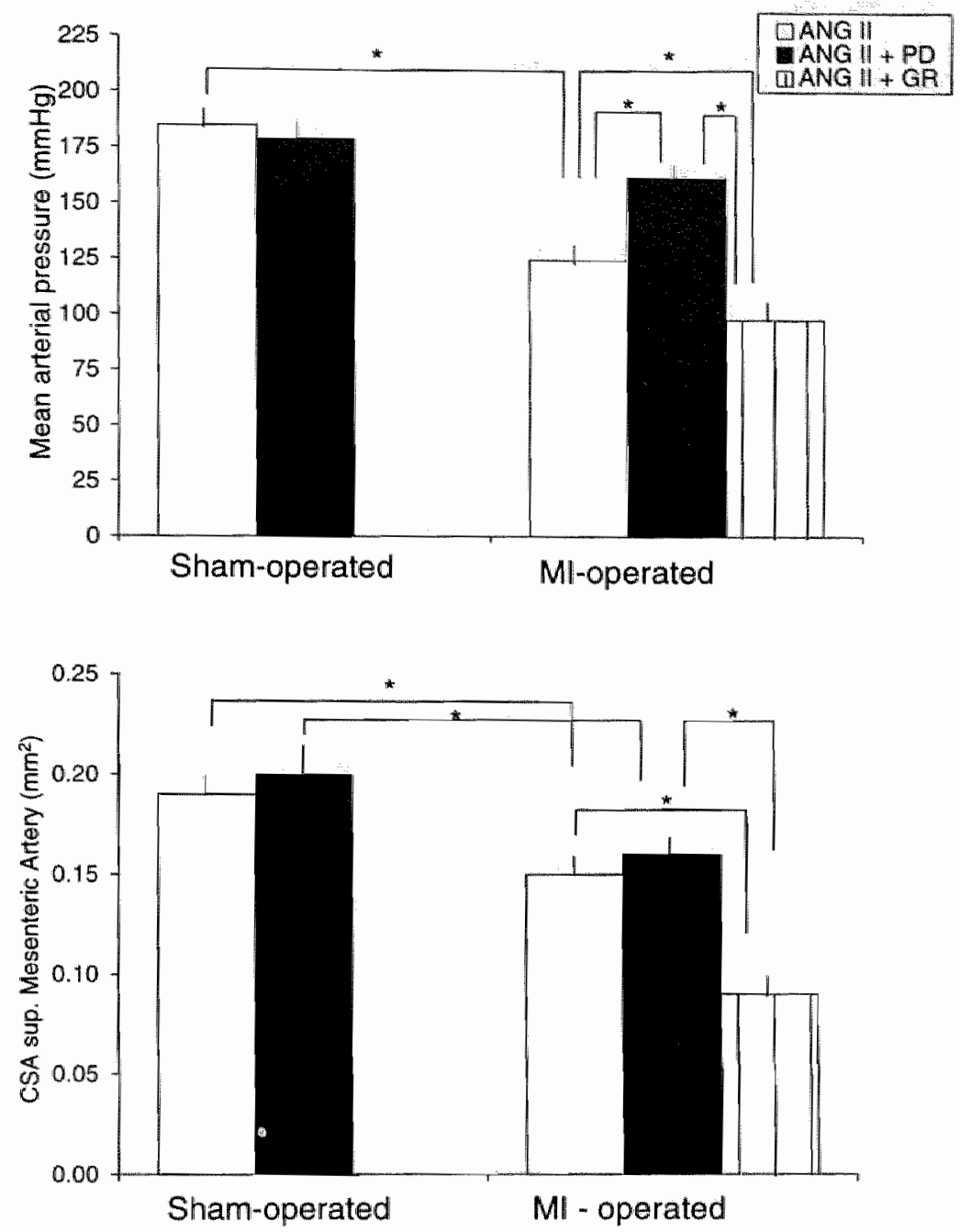

Figure 4.1 Graph showing the effects of the different infusion protocols on mean arterial blood pressure $(\mathrm{mmHg}$, top panel) and medial cross-sectional area of the superior mesenteric artery $\left(\mathrm{mm}^{2}\right.$, bottom panel). $p<0.01$ by Mann-Whitney test with Bonferroni correction.

\section{Structural methods}

After the measurements of mean arterial blood pressures and heart rates, rats were prepared for perfusion fixation. For tissue processing and morphometric measurements, see the materials and methods in chapter 2. 


\section{Statistics}

Data are expressed as means $\pm S E M$. Intergroup differences were evaluated with a non-parametric Mann-Whitney test with a Bonferroni correction for multiple group comparison. The Bonferroni procedure corrects the $p$ value for each pairwise group comparison, thus with 5 pairwise comparisons (SH-ANG versus MI-ANG, SH-ANG versus SH-ANG-PD, MI-ANG versus MI-ANG-PD, MI-ANG versus MI-ANG-GR and MI-ANG-PD versus Ml-ANG-GR), statistical significance is defined as $p<0.01$ ( $p<0.05$ divided by 5).

\section{Results}

Characteristics of experimental groups.

The mean infarct size was $46 \pm 4 \%, 41 \pm 4 \%$ and $42 \pm 2 \%$ in MI-ANG, MI-ANG-PD and MI-ANG-GR rats, respectively. Body weights at day 0 were comparable in all groups. The weight loss was approximately $40 \mathrm{~g}$ in all groups, except in GR138950 infused Ml rats, in which a small weight gain was observed during the experimental period (table 4.1).

Heart weights tended to decrease in SH-ANG-PD rats (heart weight $0.92 \pm 0.06$ $\mathrm{g}$ in SH-ANG and $0.80 \pm 0.03 \mathrm{~g}$ in SH-ANG-PD, $\mathrm{p}=0.06$ ), but were not changed in MlANG and MI-ANG-PD rats. Infusion of GR138950 in MI-ANG rats however, significantly

decreased heart weight and heart-to-body weight ratios compared to ANG II and ANG II-PD infused MI rats (table 4.1).

Lung weight (and lung-to-body weight ratios, data not shown) were increased in ANG II and ANG II-PD infused MI rats, compared to the appropriate control group of sham rats. AT1 receptor antagonism by GR138950 in ANG II infused MI rats, however, completely normalized lung weights (table 4.1).

Blood pressure measurements. At the end of the experimental period, mean arterial pressures were significantly lower in MI-ANG rats, compared to SH-ANG rats (table 4.1, figure 4.1). AT2 receptor antagonism by PD123319 did not affect mean arterial blood pressure in ANG II infused sham rats. However, blockade of the AT1 receptor in ANG II infused MI rats significantly decreased, and blockade of the AT2 receptor significantly increased mean arterial blood pressure from $124 \pm 6 \mathrm{mmHg}$ in MI-ANG rats to $162 \pm 9 \mathrm{mmHg}$ in MI-ANG-PD rats (table 4.1, figure 4.1). Heart rates were comparable in all groups.

Vessel dimensions.

Large conduit arteries: The medial cross-sectional areas of the large conduit arteries were increased in ANG II infused sham rats, compared to ANG II infused MI rats (table 4.2, figure 4.1).

AT1 receptor blockade by GR138950 in ANG II infused MI rats reduced medial 


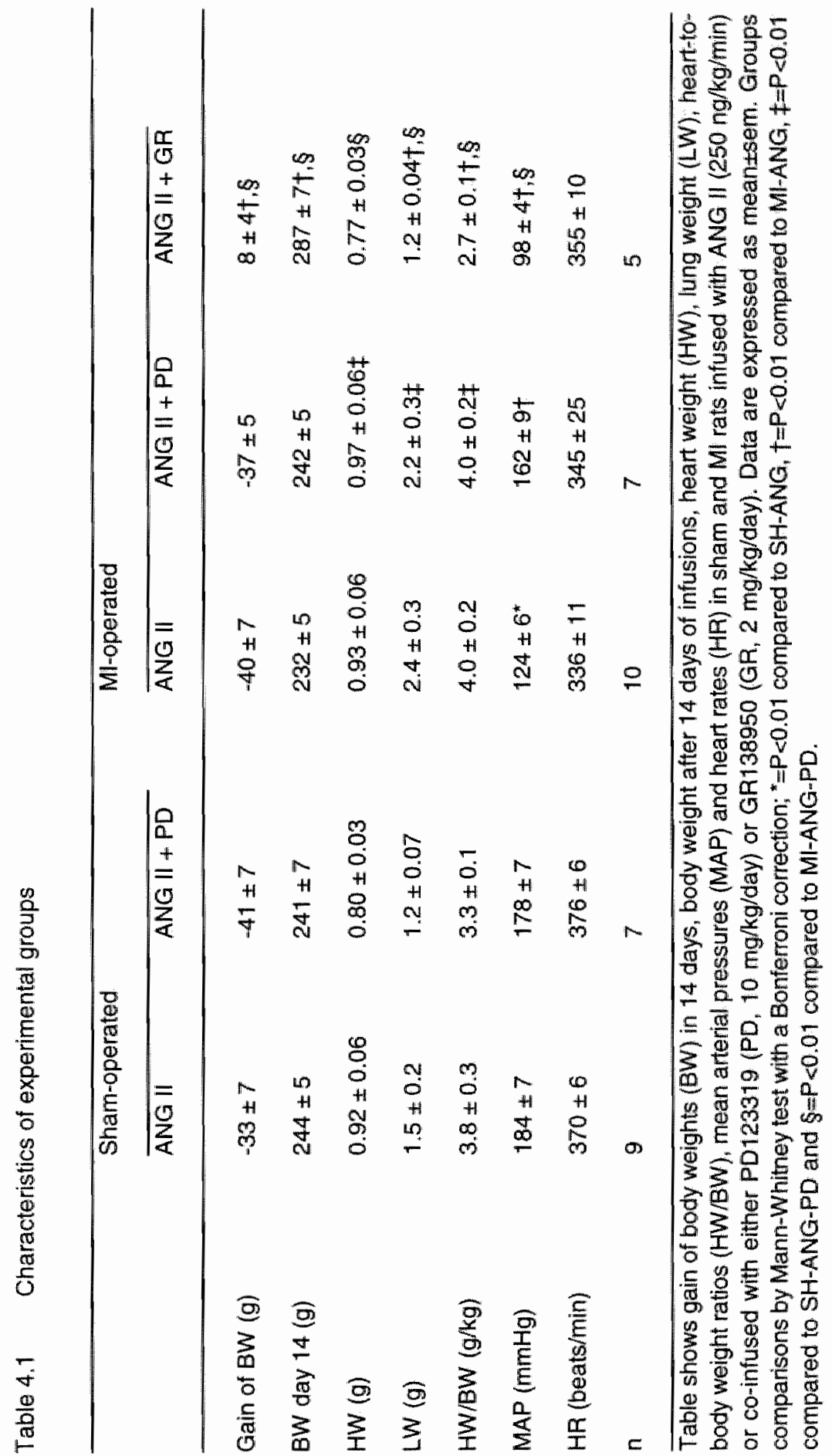


cross-sectional areas of the large conduit arteries investigated (table 4.2).

Blockade of the AT2 receptor by PD123319 in ANG II infused sham rats, further increased medial cross-sectional area of the thoracic aorta, but had no effect on medial cross-sectional arreas of the superior mesenteric artery (sMA) and carotid artery (CA). The lumen areas of the two later vessels, however tended to increase during the co-infusion of ANG II and PD (lumen area sMA; SH-ANG 0.34 $\pm 0.02 \mathrm{~mm}^{2}$ versus SH-ANG-PD 0.44 $\pm 0.04 \mathrm{~mm}^{2}, p=0.10$ and lumen area CA; SH-ANG 0.31 \pm 0.03 $\mathrm{mm}^{2}$ versus $\mathrm{SH}-\mathrm{ANG}-\mathrm{PD} 0.37 \pm 0.04 \mathrm{~mm}^{2}, \mathrm{p}=0.06$ ). The increase in lumen diameter resulted in a decrease in the media-to-lumen ratio of the superior mesenteric artery, although the difference did not reach statistical significance (SH-ANG $57 \pm 3 \%$ versus SH-ANG-PD $46 \pm 3 \%, p=0.02$ ).

Blockade of the AT2 receptor by PD123319 in ANG II infused MI rats did not increase medial cross-sectional area of the large conduit arteries (table 4.2, figure 4.1), although the medial cross-sectional area of the carotid artery tended to increase (MI-ANG $0.11 \pm 0.01 \mathrm{~mm}^{2}$ versus MI-ANG-PD $0.13 \pm 0.01 \mathrm{~mm}^{2}, p=0.02$; table 4.2). As the lumen diameter of the superior mesenteric artery of rats co-infused with $P D$ and ANG II increased compared to MI rats infused with ANG II alone, the media-tolumen ratio tended to decrease (MI-ANG $51 \pm 4 \%$ versus MI-ANG-PD $40 \pm 2, p=0.03$, table 4.2 ).

Resistance arteries: There were no differences between ANG II infused sham and MI rats for the different types of resistance arteries.

AT1 receptor antagonism in ANG II infused MI rats had major effects on vessel dimensions of the resistance arteries. Medial cross-sectional areas of the pulmonary vascular bed were significantly smaller and medial cross-sectional areas of the mesenteric resistance arteries tended to be smaller (MRA ${ }^{2 n d}$ order MI-ANG $21351 \pm 2077 \mathrm{~mm}^{2}$ versus Ml-ANG-GR $13772 \pm 2000 \mathrm{~mm}^{2}, p=0.03$ ). Also, media-tolumen ratios of the $2^{\text {nd }}$ order mesenteric resistance arteries were significantly smaller compared to ANG II infused MI rats.

AT2 receptor antagonism in ANG II infused sham rats had no effect on medial cross-sectional areas of all investigated resistance arteries. The media-to-lumen ratio of the $2^{\text {nd }}$ order mesenteric resistance arteries of PD123319 treated ANG II infused sham rats tended to decrease (media-to-lumen-ratio SH-ANG $61 \pm 10$ versus SHANG-PD 43 $\pm 2, p=0.06$ ). AT2 receptor antagonism in ANG II infused $M I$ rats had no effects on vessel dimensions of the resistance arteries (table 4.3).

\section{Discussion}

In this study, infusion of exogenous ANG II after myocardial infarction was used to create a model of compensated heart failure with increased plasma concentrations of ANG 11. Previous work showed that this infusion of ANG II resulted in a comparable decrease in cardiac function in $\mathrm{Ml}$ and sham rats. Further effects of this 


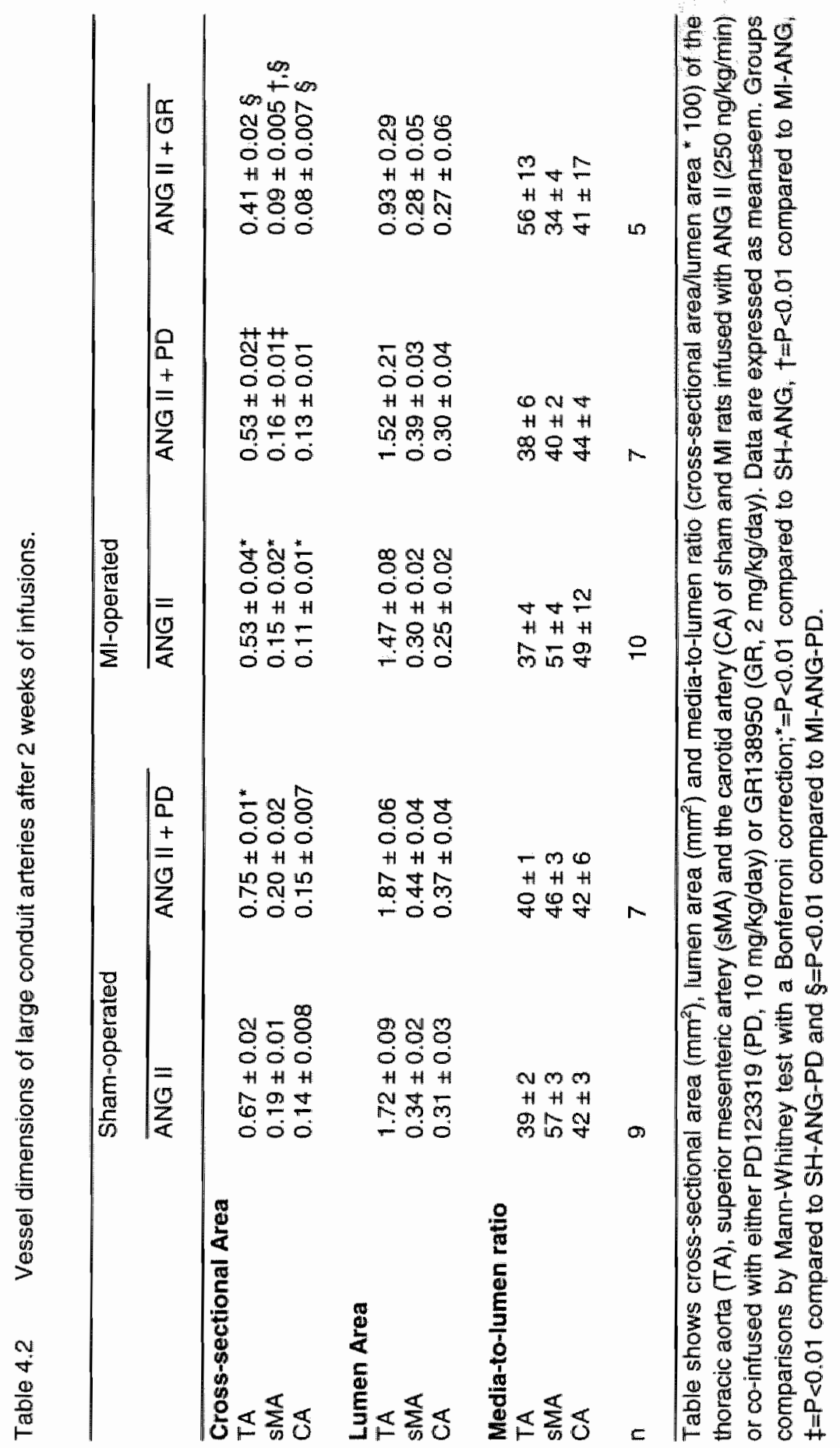


infusion in sham, but not in Ml rats, were a substantial increase in blood pressure and hypertrophy of the peripheral vascular wall. In the present study, the hypothesis was tested that changes in AT receptor subtypes are responsible for this phenomenon.

It is well established that the AT1 receptor mediates vasoconstriction and tha' blockade of this receptor reduces blood pressure $(4,11,12)$. The results of the present study agree with this finding as blockade of the AT1 receptor in ANG I infused $M I$ rats significantly reduced blood pressure. In contrast to the effects of AT1 receptor blockade, other studies have shown that infusion of PD123319 alone did no increase blood pressure $(4,11)$. However, studies in mice with targeted disruptior of the AT2 receptor gene exhibited an increased basal blood pressure (5) and ar enhanced response to ANG II $(5,15)$, suggesting that the AT2 receptor may oppose the pressor responses to ANG II. Although the present study also showed no effects of the AT2 blockade on the blood pressure of ANG II infused sham rats, co-infusior of ANG II and PD123319 did increase blood pressure in MI rats. This may depenc upon a change in the AT receptor sub-populations in the peripheral vasculature.

Opposing effects of the AT1 and AT2 receptors have also been described for the regulation of vascular structure. The proliferative and hypertrophic effects of ANG I are predominantly regulated by the AT1 receptor, but the AT2 receptor has beer shown to induce an antimitogenic effect on rat coronary endothelium cells (6) anc R3T3 cells (16). Also, the AT2 receptor mediates apoptosis in a rat pheochromo. cytoma cell line (17). Overexpression of the AT2 receptor by transfecting an ATs receptor vector in the balloon-injured carotid artery attenuated neointimal formatior indicating similar effects in vascular smooth muscle cells (18).

The peripheral structural effects of the blockade of the AT1 receptor were ven homogenous in the large conduit arteries, since all 3 exhibited a decreased media cross-sectional area. During co-infusion of ANG II and an AT1 antagonist, ANG II is expected to exert a selective stimulation of the AT2 receptor. Thus, the decrease ir medial cross-sectional areas of large conduit arteries during the blockade of the AT1 receptor, indicates that in MI rats, the AT2 receptor down-regulates vascular growth

In contrast, the structural vascular effects of blockade of AT2 receptor were heterogenous in both sham and MI rats. During co-infusion of ANG II and an ATs antagonist, ANG II is expected to selectively stimulate the AT1 receptor. Thus, as infusion of PD123319 induced an additional increase in medial cross-sectional aree of the thoracic aorta of sham rats, this suggests that the AT2 receptor is involved ir regulation of vascular wall structure of this vessel. In the superior mesenteric anc carotid arteries, no effects on medial cross-sectional area were seen during infusior of PD123319 in sham rats. In MI rats, blockade of the AT2 receptor did not change medial cross-sectional area of the thoracic aorta or the other large conduit arteries investigated.

The heterogenous response of the AT1 and AT2 receptor blockades on blooc 


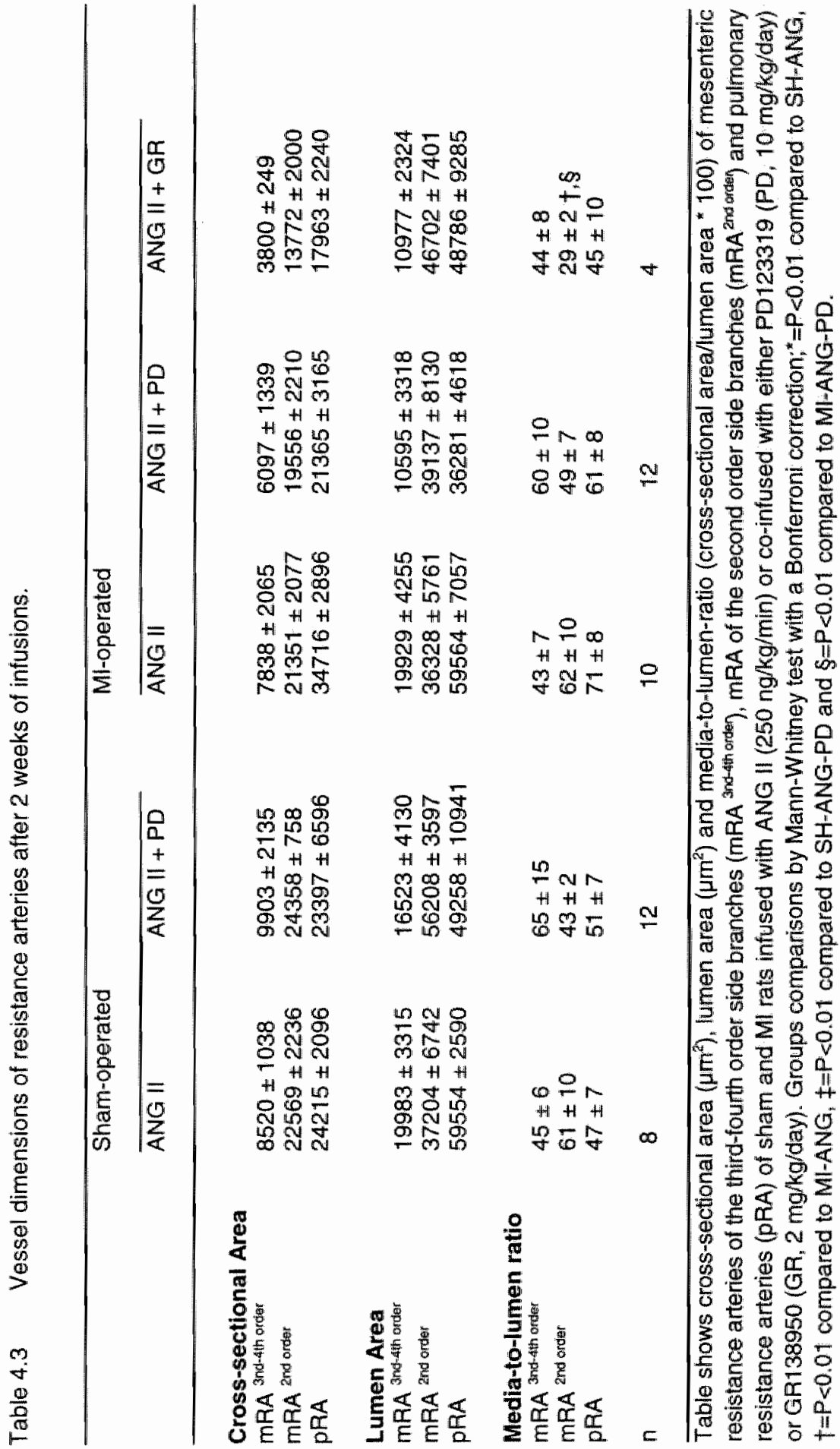


pressure and vascular structure in $\mathrm{MI}$ and sham rats may be explained by differen ratios of $\mathrm{AT} 1$ and $\mathrm{AT} 2$ receptors along the vascular tree on the one hand anc between $\mathrm{MI}$ and sham rats on the other. A wide variety in the relative proportion o: AT receptor subtypes has been shown, not only among different tissues of the same species, but also within the same tissue of different species (19). This is alsc reflected by the wide variety of contractile responses to ANG II of aortic rings from different vessels. Juul et al. showed that ANG II in the rat induced the stronges contraction in the femoral artery, followed by a 2.5 fold reduction in contractile force of the cerebral artery, 5.3 fold reduction of the mesenteric artery and 15 folc reduction of the renal arteries (20). Differences which could be explained by a smaller amount of AT1 receptors, or a higher amount of AT2 receptors, opposing the contractile effects of the AT1 receptor.

During heart failure, changes in the cardiac AT-receptor population have been described, but, data are lacking on the status of vascular AT-receptors. Preliminary data from our laboratory on AT1 and AT2 receptor mRNA expression in peripheral arteries (carotid and superior mesenteric artery) determined by the competitive reverse transcriptase polymerase chain reaction $(21,22)$ show several interesting findings. Firstly, significant amounts of AT2 receptor mRNA transcripts are preseni in both the carotid and superior mesenteric artery $(\sim 1000 \mathrm{fg} / \mathrm{pg}$ RNA $)$, and its expression exceeded that of AT\| receptor transcripts ( $100 \mathrm{fg} / \mathrm{pg}$ RNA). This is surprising as most studies detecting vascular AT1 and AT2 receptors on the protein level by autoradiography showed a relative abundancy of AT1 receptors $(70-80 \%)$ over AT2 receptors $(20-30 \%)(19,23,24)$. Secondly, there is a tendency for higher AT2 receptor mRNA expression in the ANG II infused $M I$ rats compared to ANG II infused sham rats, suggesting a change in regulatory mechanisms in the turnover of this receptor. The levels of AT1 receptor are variable, but unchanged. These preliminary data, which must be completed with autoradiographic studies, combined with the antagonist studies suggest that an upregulation of vascular AT2 receptors could be involved in the suppression of hypertensive and hypertrophic effects of ANG II during heart failure.

Changes in the AT1 and AT2 receptors may not be the sole explanation for the divergent effects of AT2 receptor blockade on vascular structure. The reninangiotensin system is known to interact with several other neurohormonal systems, which may have an effect on the vascular structure. A candidate in this respect is the Nitric Oxide system (NO). ANG II has been shown to modulate NO release from the vascular endothelium $(25,26)$ and recent results from our laboratory show that coinfusion of ANG II and an inhibitor of NO synthase (L-NAME) in MI rats increases the medial cross-sectional area of the thoracic aorta, the superior mesenteric artery and the carotid artery, but has, in contrast to PD123319, no effect on mean arterial blood pressure (see chapter 5 ). The activation of other neuro-hormonal systems, such as NO, during infusion of ANG II in MI rats could also explain the dissociation of the effects of the AT receptor blockers on blood pressure and peripheral vascular 
structure.

In conclusion, the reduction of both blood pressure and medial cross-sectional areas during co-infusion of ANG $\|$ and the AT2 receptor antagonist GR138950 suggests that the AT2 receptor opposes the effects of the AT1 receptor in the regulation of blood pressure and peripheral vascular structure in MI rats. Furthermore, the observation that AT2 receptor blockade does increase blood pressure in ANG II infused MI rats, but not in sham rats, confirms that the AT2 receptor is involved in blood pressure regulation in Ml rats. Moreover, as AT2 receptor blockade did not influence medial cross-sectional areas, this suggests that there are either variations in the AT1 and AT2 receptor populations of different vessels or that other mechanisms are also involved in the regulation of peripheral vascular structure in Ml rats. 


\section{References}

1. Paul M, Pinto YM, Schunkert $H$, Ganten $\mathbb{D}_{\text {, }}$ Bôthm $\mathrm{M}$. Activation of the renin-angiotensin system in heart failure and hypertrophy. Studies in human hearts and transgenic rats. Eur Heart $J 1994 ; 15: 63$. 67.

2. Sealey JE, Laragh JH: The reninangiotensin-aldosteron system for normal regulation of blood pressure and sodium and potassium homeostasis, in Laragh $J H$, Brenner BM (eds): Hypertension. Pathophysiology, diagnosis, and management. New York, Raven Press, 1990, vol 1, pp. 1287-1317.

3. Lever AF. Angiotensin II, angiotensin-converting enzyme inhibitors and blood vessel structure. Am J Med 1992;92:35s-38s.

4. van Kleef EM, Fingerle J, Daemen MJAP. Angiotensin II induced progression of neointimal thickening in the balloon injured rat carotid artery is AT-1 receptor Imediated. Arterioscl Thromb Vasc Biol 1996;16:857-863.

5. Ichiki T, Labosky PA, Shiota C, Okuyama

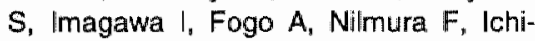
kawa I, Hogan BLM, Inagami T. Effects on blood pressure and exploratory behaviour of mice lacking angiotensin 11 type 2 receptor. Nature 1995;377:748750.

6. Stoll $M$, Steckelings $M$, Paul $M$, Biottari $S P$. Metzger $R$, Unger $T$. The angiotensin AT2-receptor mediates inhibition of cell proliferation in coronary endothelial cells. $J$ Clin Invest 1995;95:651-657.

7. MicAlpine HM, Morton $\mathrm{JJ}$, Leckie B, Rumley A, Gillen G, Dargie HJ. Neuroendocrine activation after acute myocardial infarction. Br Heant J 1988;60:117-124.

8. Dzau VJ, Colucci WS, Hollenberg NK, Williams GH. Relation of the reninangiotensin-aldosteron system to clinical state in congestive heart failure. Circula- tion 1981;63:645-651.

9. Francis GS, Cohn JN, Johnson $G_{\text {, }}$ Rector TS, Goldman S, Simon A. Plasma norepir nephrine, plasma renin activity and congestive heart failure. Relations to survival and the effects of therapy in V-HeFT II. Circulation 1993;87:V/40-VI48.

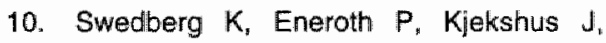
Wilhelmsen $L$. Hormones regulating cardiovascular function in patients with severe congestive heart failure and their relation to mortality. Circulation 1990; 82:1730-1736.

11. Levy BI, Heymes $C_{n}$ Caputo $L_{n}$ Benessiano J. Poitevin P, Duriez $M_{*}$ Samuel JL. Chronic blockade of AT2-subtype receptors prevents the effect of angiotensin II on rat vascular structure. J Clin invest 1996:98:418-425.

12. Wong $P C$, Bernard $\mathrm{A}$, Timmerman PBMWM. Effect of blocking angiotensin-II receptor subtype on rat sympathetic nerve function. Hypertension 1992; 9: 663-667.

13. Fishbein MC, Maclean D, Maroko PR. Experimental myocardial infarction in the rat. Am J Pathol 1978;90:57-70.

14. Macari D, Whitebread S, Cumin F, De Gasparo M, Levens N. Renal actions of the angiotensin AT-2 receptor ligands CGP 42112 and PD123319 after blockade of the reniri-angiotensin system. Eur $J$ Pharmacol 1994;259:27-36.

15. Hein L, Barsh GS, Pratt RE, Dzau VJ, Koblika BK. Behavioural and cardiovascular effects of angiotensin 11 type -2 receptor gene in mice. Nature 1995;377:744747.

16. Tsuzuki S, Matoba T, Eguchi S, Inagami T. Angiotensin II Type 2 receptor inhibits cell proliferation and activates tyrosine phosphatase. Hypertension 1996;28:916- 
918.

17. Yamada T, Horiuchi M, Dzau VJ. Angiotensin II type 2 receptor mediates pro. grammed cell death. Proc Nati Acad Sci US A $1996: 93: 156-160$.

18. Nakajima $M$, Hutchinson $H G$, Fujinaga $M$, Hayashida $W$, Morishita $R$, Zhang $L$, Horiuchi $M$, Pratt RE, Dzau VJ. The angiotensin II type 2 (AT2) receptor antagonizes the growth effects of the AT1 receptor: gain-of-function situdy using gene transfer. Proc Natl Acad Sci U S A 1995; 2:10663-10667.

19. Chang RS, Lotti VJ. Angiotensin receptor subtypes in rat, rabbit and monkey tis. sues: relative distribution and species. dependency. Life Sci 1991;49:1485-1490.

20. Juul $B$, Aalkjaer C, Mulvany MJ. Responses of femoral resistance arteries to angiotensin in vitro. Eur J Pharmacol 1987; 35:61-68.

21. Passier RCJJ, Smits JFM, Verluyten MJA, Daemen MJAP. Expression of renin and angiotensinogen in rat heart after myocardial infarction. Am J Physiol 1996; 71: $\mathrm{H} 1040 . \mathrm{H} 1048$

22. Passier RC, Smits JF, Verluyten MJ, Studer $\mathrm{R}$, Drexler $\mathrm{H}_{\text {, Daemen MJ. Activation }}$ of angiotensin-converting enzyme expression in infarct zone following myocardial infarction. Am J Physiol 1995;269:H1268H1276.

23. Song $K$, Kurobe $Y$, Kanehara $H$, Wada $T$, Inada $Y$, Nishikawa K, Miyazaki M. Mapping of angiotensin II receptor subtypes in peripheral tissues of spontaneously hypertensive rats by in vitro autoradiography. Clin Exp Pharmacol Physiol 1995;22 Suppt 1:S17-S19.

24. Viswanathan $M$, Tsutsumi $K$, Correa FMA, Saavedra JM. Changes in expression of angiotensin receptor subtypes in the rat aorta during development. Biochem Biophys Res Commun 1991; 79:1361-1367.
25. Caputo L, Benessiano J Boulanger $\mathrm{CM}_{\text {s }}$ Lewy BI. Angiotensin II increases oGMP content via endothelial angiotensin II ATI subtype receptors in the rat carotid artery. Arterioscl Thromb Vasc Biol 1995; 5: 1646-1651.

26. Boulanger CM, Caputo L, Lewy Bl. Endothelial AT1-mediated release of nitric oxide decreases angiotensin II contractions in rat carotid artery. Hypentension $1995 ; 26: 752-757$. 

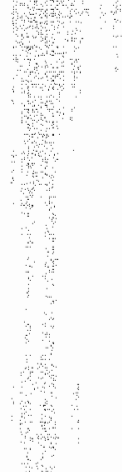

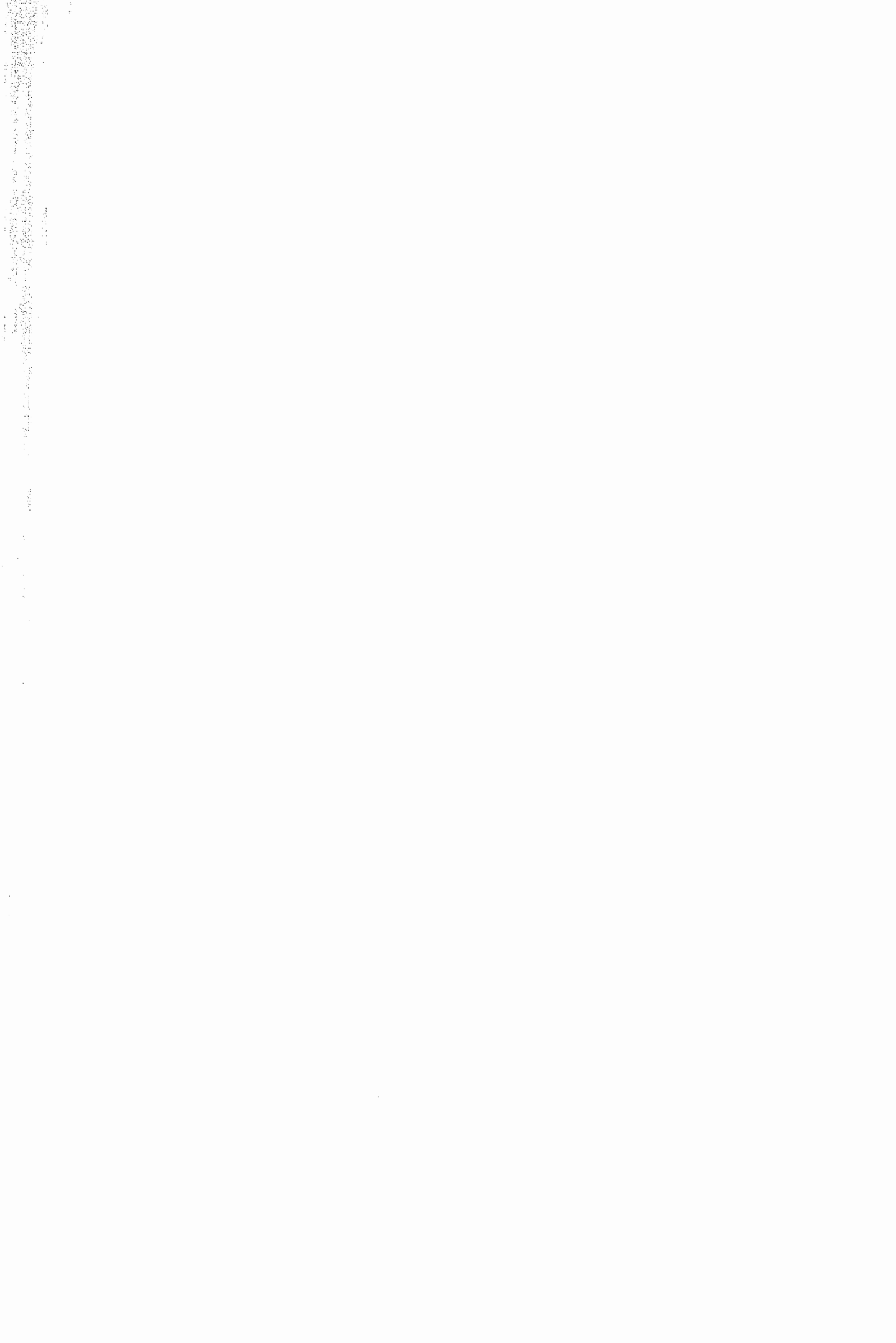




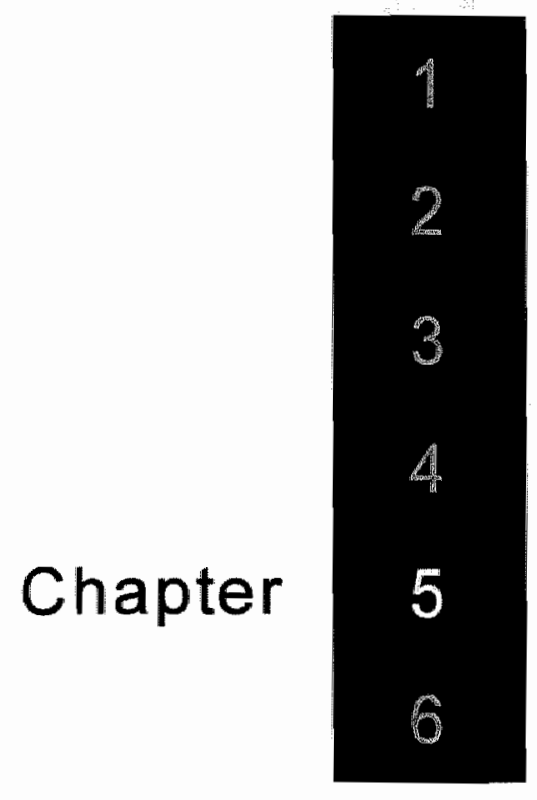

\section{Vascular Structure and Basal Release of Nitric Oxide during Experimental Heart Failure in the Rat}

Sylvia Heeneman, Debbie Brouwers-Ceiler, Peter Leenders, Jos Smits, Mat Daemen

Submitted for publication 


\section{Chapter 5}

\begin{abstract}
Chronic heart failure is associated with an endothelial dysfunction and impaired vascular responsiveness to vasoconstrictors. The first objective in the present study, was to determine whether heart failure induces changes in the basal release of nitric oxide (NO), and therefore an inhibitor of NO synthase, $\mathrm{N}^{\omega}$-nitro-l-arginine methyl ester (L-NAME, $25 \mathrm{mg} / \mathrm{kg} /$ day) or saline $(0.9 \% \mathrm{NaCl})$, were infused for two weeks in rats with a myocardial infarction (MI). Secondly, it was shown in previous studies that infusion of angiotensin II (ANG II) did not result in the expected hypertension and hypertrophy of the peripheral vascular wall in MI rats. Therefore, a co-infusion of ANG II and L-NAME was given in an additional group of $\mathrm{Ml}$ rats to investigate whether the release of NO is involved in the effects of ANG II on blood pressure and peripheral vascular structure. Results: Aortic cyclic GMP (cGMP) concentrations as an indicator of NO synthase activity, did not differ in saline inlused MI or sham rats, while L-NAME infusions significantly reduced aortic CGMP contents in both groups. L-NAME elevated mean arterial blood pressure by $31 \pm 5 \%$ in sham-operated rats. In $M I$ rats, a similar increase in mean arterial pressure $(22 \pm 4 \%$ ) was observed, although the blood pressure did not increase above the level of normotensive control rats. The changes in peripheral vascular structure during L-NAME infusions differed in sham and MI
\end{abstract}

rats. L-NAME infusions caused a marked increase in medial cross-sectional area (CSA) of the large conduit arteries in sham rats. In contrast, in MI rats, L-NAME increased the CSA of the carotid artery only, but had no effect on the CSAs of the thoracic aorta and superior mesenteric artery. Medial CSAs of the pulmonary and mesenteric resistance arteries were unaffected by L-NAME infusions in both groups. In the additional group of ANG II infused MI rats, L-NAME did not increase bload pressure, but had profound effects on peripheral vascular structure as the medial CSA of both large conduit and resistance arteries increased significantly.

In conclusion, L-NAME infusions induced similar blood pressure elevations in sham and MI rats. Since aortic CGMP concentrations were comparable in saline infused sham and $M I$ rats, these results suggest basal release of NO is intact during experimental heart failure. However, the response on vascular structure differed markedly in L-NAME infused MI and sham rats. The co-infusion of ANG \|l and L-NAME in MI rats had no further effect on blood pressure but did increase the CSA of both large conduit and resistance arteries. This suggests that NO modulates the hypertrophic but not the hypertensive effects of ANG $\|$ in MI rats. 


\section{Introduction}

Nitric oxide (NO), released from the vascular endothelium, plays an important role in endothelium-dependent vasodilation $(1,2)$. The continuous basal release of NO has been shown to contribute to the regulation of basal vascular tone (reviewed in reference 3 and 4). In addition to this basal release, endothelial NO release can be induced by several agonists such as acetylcholine and bradykinin (reviewed in reference 1 and 2). Recently, abnormalities of the vascular endothelium during heart failure have received considerable attention. Various reports, both in animals (5-7) and patients (8-10), show that agonist induced endothelium-dependent vasodilation is impaired in heart failure, indicating a reduced release of endothelial NO. In contrast, reports on changes in the basal production during heart failure are conflicting. Human studies report an intact $(8,11)$ or even enhanced basal release of NO $(12,13)$. Ex vivo animal studies using isolated vascular rings, however, show decreased basal release of $N O(6,14)$.

Besides its important role in the regulation of vascular tone, NO is also involved in the regulation of vascular structure as it inhibits vascular smooth muscle cell proliferation $(15,16)$. Little is known about this effect of NO during heart failure. in previous work, we have shown that (i) induction of a myocardial infarction in rats resulted in a reduced peripheral vascular growth (chapter 2) and that (ii) ANG II infusion in Ml rats did not induce hypertension nor vascular hypertrophy (chapter 3). Since ANG II has been shown to modulate NO release from the vascular endothelium $(17,18)$, we speculate that NO might antagonize the hypertensive and vascular hypertrophic effects of ANG II in MI rats.

In the present study, we therefore wanted to determine (i) whether experimental heart failure induces changes in the basal release of NO, (ii) whether NO is involved in the regulation of peripheral vascular structure and (iii) whether NO antagonizes the effects of ANG II during heart failure. Therefore, an inhibitor of NO synthase, $N^{\omega}$. nitro-l-arginine methyl ester (L-NAME) or saline $(0.9 \% \mathrm{NaCl})$ were continuously infused for two weeks in $\mathrm{MI}$ and sham-operated rats. In an additional group of $\mathrm{MI}$ rats, a co-infusion of L-NAME and ANG II was given. The data indicate that the basal release of NO is intact during experimental heart failure and that NO antagonizes the vascular hypertrophic but not the hypertensive effects of ANG II in MI rats.

\section{Materials and methods}

\section{Animals}

Male Wistar rats $(n=113,200-250 \mathrm{~g}$ at start of training on day -14 , Iffa Credo, Someren, the Netherlands) were housed under standard conditions and fed standard rat chow (RMH-TM, Hope Farms, Woerden, The Netherlands) and water ad libitum. The experiments were performed in accordance with local institutional guidelines. The randomization scheme is shown in figure 5.1. From the 113 rats used, 13 died 


\section{Study Protocol}

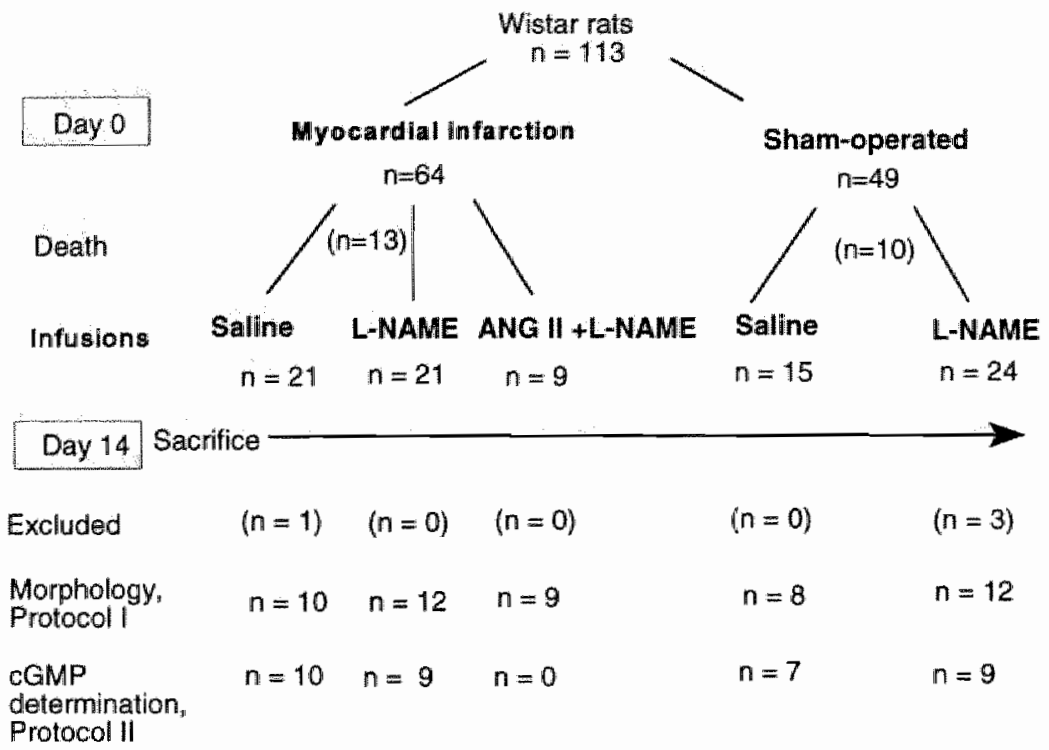

Figure 5.1 Outline of the research protocol with randomization scheme

following coronary artery ligation and 10 following sham surgery. From the 90 remaining rats, 51 were used for blood pressure and morphometric measurements (protocol 1), and 35 rats for the determination of aortic cGMP (protocol 2). The remaining 4 rats had infarct sizes less than $20 \%$ of left ventricular circumference, or showed non-transmural infarcts.

\section{Coronary artery ligation}

Myocardial infarction was induced by ligation of the left anterior descending coronary artery (LAD) according to the method of Fishbein (19) as described in chapter 2.

\section{Experimental protocol}

Rats were randomly assigned to either the protocol for blood pressure and morphometric measurements (protocol 1, $n=51$ ) or determination of aortic cGMP content (protocal 2, n=35) as outlined in figure 5.1. For each study, rats were subsequently randomized to the following groups: $\mathrm{SH}-\mathrm{NaCl}$ (protocol $1: n=8$, protocol 2: $n=7)$ were subjected to sham surgery and infused with saline $(0.9 \% \mathrm{NaCl})$. MI$\mathrm{NaCl}$ (protocol 1: $n=10$, protocol 2: $n=10$ ) were infused with saline following induction of a myocardial infarction (MI). SH-NAME (protocol 1: $n=12$, protocol $2: n=9$ ) and MI- 
NAME (protocoll 1: $n=12$, protocol $2: n=9$ ) were subjected to sham and MI surgery respectively, and infused with $\mathrm{N}^{\omega}$-nitro-l-arginine methyl esther (L-NAME, Sigma). In a previous study (chapter 3 ), ANG II was given to MI rats using a dose (250 $\mathrm{ng} / \mathrm{kg} / \mathrm{min}$ ) that increased mean arterial blood pressure in sham-operated animals to approximately $190 \mathrm{mmHg}$ after 14 days of infusions. However, in preliminary experiments, MI rats co-infused with L-NAME and this dose of ANG II became very ill and had excessive weight loss (average of $90 \mathrm{~g}$ during two weeks). These rats had no significant increase in mean arterial blood pressure $(137 \pm 18 \mathrm{mmHg}$ after 14 days of infusions $(n=5)$ ). Therefore, a lower dose of ANG II was used $(100 \mathrm{ng} / \mathrm{kg} / \mathrm{min})$ in the co-infusion experiment with L-NAME (MI-ANG-NAME, protocol 1, $n=9$ ). This dose of ANG II has been reported to increase blood pressure in normal rats $(20,21)$.

Infusions: Osmotic minipumps (Alzet model 2002, Alza Corporation, Palo Alto, California) were prepared containing saline, or L-NAME $(25 \mathrm{mg} / \mathrm{kg} /$ day) dissolved in saline, or ANG II (human [5Val] ANG $\| 1,100 \mathrm{ng} / \mathrm{kg} / \mathrm{min}$, Brunschwig, Amsterdam, The Netherlands). Minipumps were implanted subcutaneously between the shoulder blades, immediately following induction of a myocardial infarction or sham surgery. The duration of the infusions was 14 days.

Protocol $1:$ In this protocol, mean arterial pressures and heart rates were measured prior to sacrifice on day 14. After perfusion fixation of the vascular tree, several vessels were excised for morphological measurements. For the assessment of mean arterial pressures and heart rates on day 14 , see material and methods in chapter 3 . For tissue processing after sacrifice and morphometric measurements, see material and methods in chapter 2.

Protocol 2 : In this protocal, the thoracic aorta was excised for the determination of cyclic GMP (cGMP) concentrations (22). The in vivo basal aortic cGMP concentration depends mainly on NO synthetase (23), as the contribution of endogenous ANP, via stimulation of the particulate guanylate cyclase, to basal aortic cGMP generation appears to be minor to that of NO via soluble guanylate cyclase.

For the tissue processing and determination of cyclic GMP concentration, see the materials and methods in chapter 3.

\section{Statistics}

Data are expressed as means $\pm S E M$. Intergroup differences were evaluated with a non-parametric Mann-Whitney test with a Bonferroni correction for multiple group comparison. The Bonferroni procedure corrects the $\mathrm{p}$ value for each pairwise group comparison, thus with 5 pairwise comparisons ( $\mathrm{SH}-\mathrm{NaCl}$ versus $\mathrm{MI}-\mathrm{NaCl}, \mathrm{SH}-\mathrm{NaCl}$ versus SH-NAME, MI-NaCl versus MI-NAME, SH-NAME versus MI-NAME and MINAME versus MI-ANG-NAME), statistical significance is defined as $p<0.01 \quad(p<0.05$ divided by 5 ). 

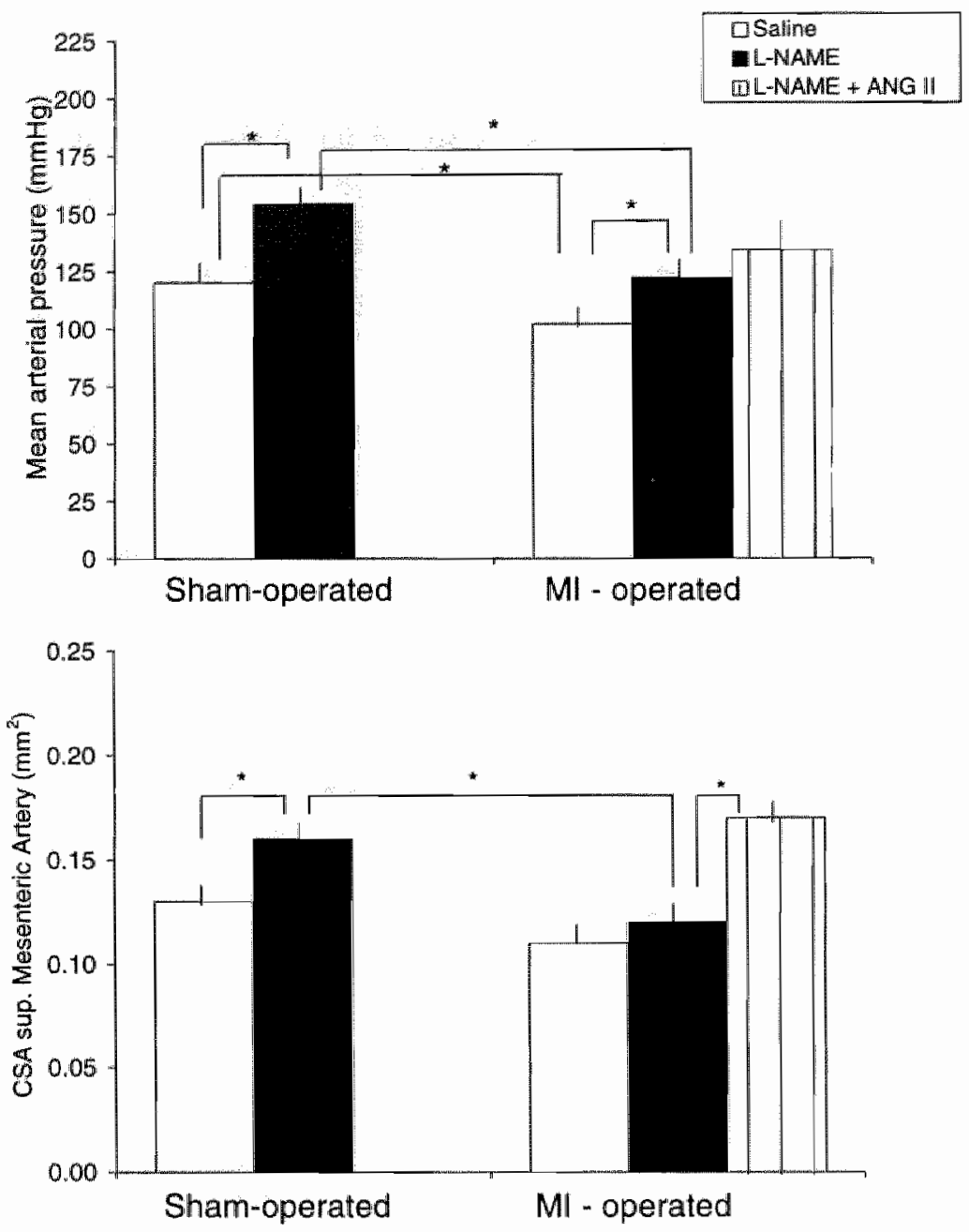

Figure 5.2 Graph showing the effects of the different infusion protocols on mean arterial blood pressure (mmHg, top panel) and medial cross-sectional area of the superior mesenteric artery $\left(\mathrm{mm}^{2}\right.$, bottom panel). " $p<0.01$ by Mann-Whitney test with Bonferroni correction.

\section{Results}

Characteristics of experimental groups (protocol 1 and 2; table 5.1). The mean infarct size was $42 \pm 4 \%$ and $42 \pm 3 \%$ in $\mathrm{MI}-\mathrm{NaCl}$ and MI-NAME rats respectively and $35 \pm 6 \%$ in the MI rats co-infused with L-NAME and ANG II. The infusion of L-NAME resulted 


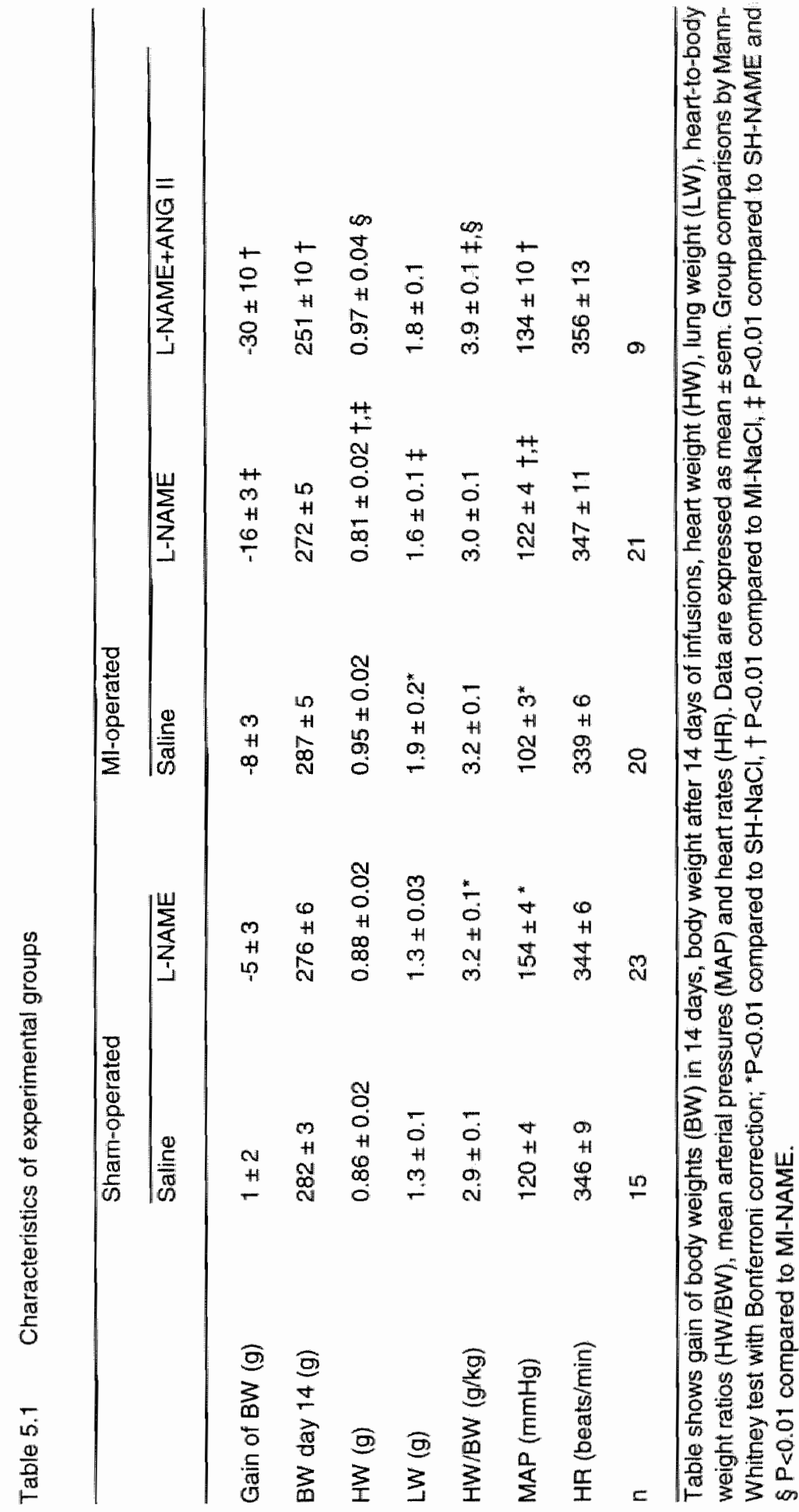


in a decreased body weight, which was more pronounced in ANG II infused MI rats. Infusion of L-NAME in sham rats and the subsequent hypertension increased heartto-body weight ratios, but did not affect absolute heart weight. Heart weights of MINAME rats, however, were lower compared to MI-NaCl, SH-NAME and MI-ANGNAME rats. Lung weights (table 5.1) and lung-to-body weight ratios (data not shown) of all infarct groups were increased compared to sham-operated rats.

Aortic CGMP concentrations. CGMP concentrations were not different in the saline infused rats ( $\mathrm{SH}-\mathrm{NaCl} 559 \pm 87$ versus $\mathrm{Ml}-\mathrm{NaCl} 422 \pm 72 \mathrm{fmol} / \mathrm{mg}$ protein). L-NAME treatment significantly lowered cGMP concentrations in both $\mathrm{Ml}$ and sham rats $(\mathrm{SH}$ NAME $247 \pm 36$ and MI-NAME $269 \pm 27$ fmol/mg protein, $p<0.05$ versus respective saline infused rats), confirming the inhibition of NO synthase by L-NAME.

Blood pressure measurements. At the end of the experimental period, mean arterial pressure was reduced by $20 \mathrm{mmHg}$ in $\mathrm{MI}-\mathrm{NaC} \|$ rats, compared to $\mathrm{SH}-\mathrm{NaCl}$ rats (table 5.1, figure 5.2). L-NAME infusions increased mean arterial blood pressure by $31 \pm 5 \%$ (from $120 \pm 4 \mathrm{mmHg}$ to $154 \pm 4 \mathrm{mmHg}$ ) in sham-operated rats. Although the absolute mean arterial blood pressure values of MI-NAME rats were not different from 'normotensive' $\mathrm{SH}-\mathrm{NaCl}$ rats, the relative increase in mean arterial blood pressure by L-NAME was similar $(22 \pm 4 \%$, from $102 \pm 3 \mathrm{mmHg}$ to $122 \pm 4 \mathrm{mmHg})$. Coinfusions of L-NAME and ANG $\|$ in MI rats did not increase mean arterial blood pressure (table 5.1, figure 5.2). Heart rates were comparable in all groups at the end of the experimental period (table 5.1).

Vessel dimensions. Compared to $\mathrm{SH}-\mathrm{NaCl}$ rats, induction of a myocardial infarction induced no major changes in vessel dimensions of the large conduit (table 5.2, figure 5.2), but decreased media-to-lumen ratio of the pulmonary resistance arteries (table 5.3).

L-NAME infusion in sham rats induced hypertrophy of the thoracic aorta, superior mesenteric artery and carotid artery, as medial cross-sectional area of all three vessels increased compared to $\mathrm{SH}-\mathrm{NaCl}$ rats (table 5.2, figure 5.2). Infusion of the same dose of L-NAME in MI rats did not increase medial cross-sectional area, or media-to-lumen ratio of either the superior mesenteric artery or the thoracic aorta, but did increase the medial cross-sectional area of the carotid artery. In Ml rats, the combination of ANG II and L-NAME induced the same increase in the medial crosssectional area of the large conduit arteries as L-NAME infusion alone did in the sham-operated rats, but without the increase in mean arterial blood pressure (table 5.2 , figure 5.2 ).

L-NAME infusions in sham and MI rats did not result in major changes in the vessel dimensions of pulmonary and mesenteric resistance arteries (table 5.3). The lumen area of the $2^{\text {nd }}$ order mesenteric resistance arteries of MI-NAME rats decreased compared to $\mathrm{Ml}-\mathrm{NaCl}$ rats. The media-to-lumen ratio of the pulmonary resistance arteries decreased in SH-NAME rats compared to $\mathrm{SH}-\mathrm{NaCl}$ rats. The co- 


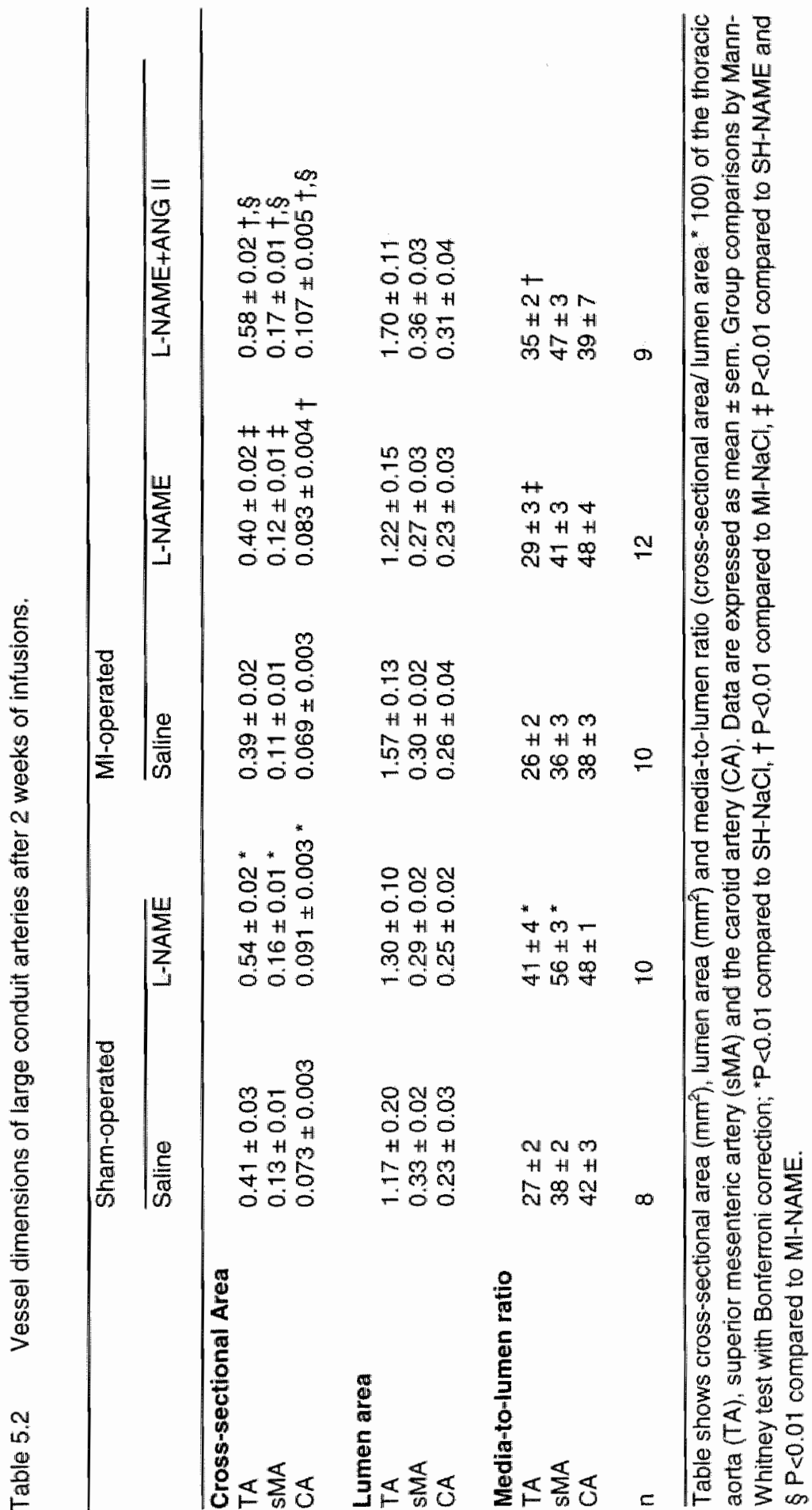


infusion of L-NAME and ANG II in MI rats, however, increased medial cross-sectional area of the mesenteric resistance arteries (table 5.3).

\section{Discussion}

This study shows that the vasoconstrictor effect of L-NAME is preserved during experimental heart failure. In MI rats, L-NAME gradually increased mean arteriall pressure, an increase which was proportional the same as that seen in sham rats. Other studies also show an increase in blood pressure during either acute or chronic L-NAME infusions in MI rats $(24,25)$. As L-NAME evokes increases in vascular resistance by continuous inhibition of the basal release of NO (3), these results, combined with the unchanged aortic cGMP concentrations in saline infused MI rats, suggest that the basal release of NO from the endothelium is preserved during experimental heart failure.

Alterations in endothelial function during heart failure have been subject of many investigations. Despite the intact basal release of NO, most reports agree upon an impaired agonist-induced release of NO. Ontkean (6) showed an impaired endothelium-dependent vasodilation in rats 10 weeks after Ml. Vasodilation in response to acetylcholine and adenosine diphosphate (both endotheliumdependent), but not to nitroglycerin (endothelium-independent) were decreased in isolated vessel rings of MI rats. Subsequently, other studies also showed impaired agonist-mediated vasodilation in isolated vascular rings of rats after $M I(7,14,26)$. In man, the endothelium dependent vasodilation is impaired in the coronary, skeletal muscle and skin circulation of patients with congestive heart failure, $(8,10,27-30)$.

The present study demonstrates that, despite the similar proportional increase in mean arterial blood pressure, absolute values were significantly lower compared to L-NAME infused sham rats. In a previous study, we observed a suppressed response to the hypertensive effects of ANG $I$ in MI rats (chapter 3 and 4). While ANG II increased the blood pressure in sham-operated rats after 14 days of infusions $(189 \pm 5 \mathrm{mmHg}$, relative increase of $47 \pm 4 \%$ ), it did not increase the blood pressure of $\mathrm{Ml}$ rats above the level of normotensive controls $(126 \pm 4 \mathrm{mmHg}$, relative increase of $21 \pm 4 \%$ ). This decrease in responsiveness to vasoconstrictors in MI rats may be related to changes in contractility of the vascular smooth muscle cells. However, Stassen et al. showed that the contractility of the thoracic aorta and mesenteric resistance arteries in MI rats was comparable to that in sham rats, three weeks after surgery $(31,32)$. In addition, the present study shows that despite the intact basal release of NO in MI-rats, inhibition of NO release by L-NAME in ANG II infused MI rats did not further increase the blood pressure, indicating that $\mathrm{NO}$ is not involved in counterregulating the effects of ANG II on blood pressure in MI rats.

Another interesting aspect of this study was the differential effects of the infusions on peripheral vascular structure. For NO, studies have shown that both exogenous nitrogen vasodilators and inducers of endogenous NO, such as interferon- $\gamma$, 


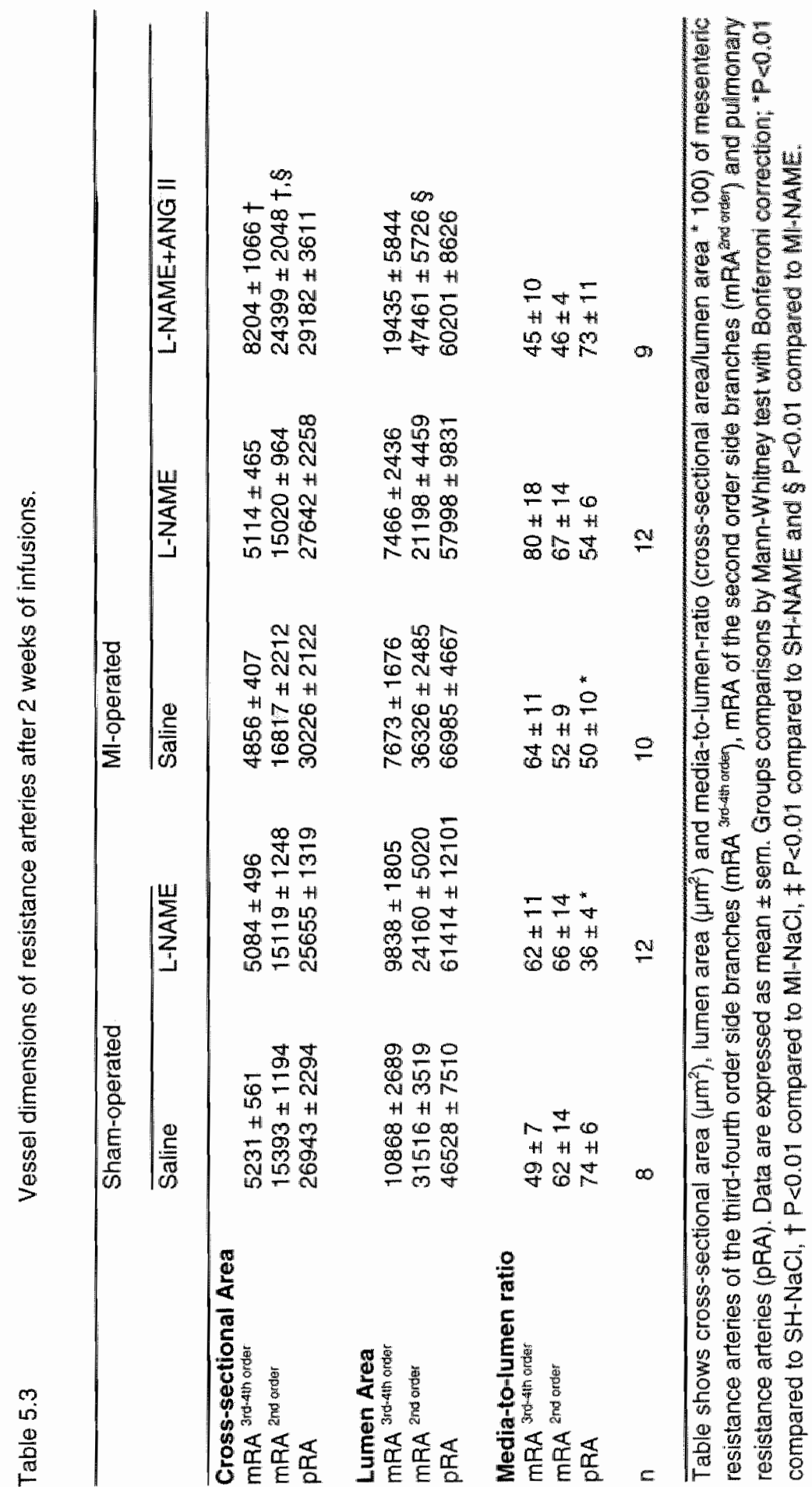


decrease vascular smooth muscle cell proliferation $(15,16)$. NO's antimitogenic effects on vascular smooth muscle cells can be modulated by several growth factors. Platelet-derived-growth-factor decreases the induction of NOS and thus the antimitogenic effects of $\mathrm{NO}$, while fibroblast growth factor enhances the induction of NOS and promotes the antimitogenic effect of NO (33).

In the L-NAME treated sham rats, suppression of NO-mediated anti-mitogenic and/or apoptotic effects of NO (34) resulted in a vascular hypertrophy of the large conduit arteries. Other studies have also shown this increase in cross-sectional area of large conduit arteries during L-NAME infusions $(35,36)$. In the resistance arteries, however, the existence of structural vascular alterations during L-NAME infusions is still controversial. Some studies do report structural changes in resistance vessels in L-NAME treated rats (37-39), while the present and other studies cannot confirm these findings $(36,40)$. The reason for these discrepancies could be well due to the methodology used, as different techniques for in vitro investigations of these small vessels were used (wire-myograph versus the pressurized small artery preparation) (41). The present study used perfusion fixation of the intact vascular tree at maximal vasodilation and demonstrates that a two week L-NAME infusion did not induce vascular hypertrophy of the resistance arteries. The different findings in large conduit and resistance arteries is not an unknown phenomenon. NO relaxes the pulmonary conduit arteries more than pulmonary resistance arteries (42), due to the existence of morphologically distinct smooth muscle phenotypes (43-45). Also, it has been shown that in large conduit arteries such as the aorta and superior mesenteric artery, NO synthase inhibition eliminated endothelium-dependent relaxations to acetylcholine, while in the mesenteric resistance arteries and hindlimb circulation, the endothelium-dependent relaxation was resistant to NO synthase inhibition (46-48).

In previous work, we have shown that Ml rats had smaller medial cross-sectional areas of several large conduit arteries, compared to sham-operated rats of the same age and weight (chapter 2). If NO is involved in this suppression of vascular growth, L-NAME should have some effect on the peripheral vascular structure in MI rats. LNAME alone had no effect on medial cross-sectional area of the thoracic aorta and superior mesenteric artery of the MI rats, but it did increase the medial crosssectional area of the carotid artery (table 5.2). Although the time of infusion may have been too short to induce changes in all vessels, this indicates that NO may be involved in peripheral vascular alterations during heart failure. The changes in peripheral vascular structure during co-infusion of L-NAME and ANG II in MI rats supports this observation. Thus, endogenous NO may be involved in counteracting the growth-stimulating effects of ANG II during experimental heart failure. This is surprising, as NO was ineffective in counterregulating the effects of ANG II on blood pressure. One possible explanation for this dissociation is that during heart failure other neuro-humoral factors are dominant over the effect of NO on blood pressure regulation or that $\mathrm{NO}$ as a regulator of vascular structure is predominantly active at the local level. 
In conclusion, this study showed that (i) the basal release of NO is intact during experimental heart failure, (ii) the peripheral vasculature of MI rats is relatively unresponsive to potential stimulators of vascular smooth muscle cell proliferation and (iii) the indifferent response to these growth-stimulating factors may be explained by a concomitant upregulation of inhibitors of vascular smooth muscle cell proliferation. 
1. Vane JR, Anggard EE, Bothing RM. Regulatory role of the vascular endothelium. N Engl J Med 1990;323:27-36.

2. Henderson AH. Endothelium in control. $\mathrm{Br}$ Heart J 1991;65:116-125.

3. Moncada S. Palmer RM, Higgs EA. Nitric oxide: physiology, pathophysiology, and pharmacology. Pharmacol Rev 1991; 43: 109-142.

4. Joannides $R_{1}$ Haefeli WE, Linder $\mathbb{L}$, Richard $V_{\text {, Bakkali }} E_{\text {s }}$ Thuillez $C$, Lüscher TF. Nitric Oxide is responsible for flow-dependent dilatation of human peripheral conduit arteries in vivo. Circulation 1995: 91:॥314-1319.

5. Drexier H, Lu W. Endothelial dysfunction of hindquarter resistance vessels in experimental heart failure. Am J Physiol 1992; 262: $\mathrm{H} 1640 \mathrm{H}-\mathrm{H} 1645$.

6. Ontkean $M$, Gay $R$, Greenberg B. Diminished endothelium-dlerived relaxing factor activity in an experimental model of chronic heart failure. Circ Res 1991;69:108:81096.

7. Teerlink JA, Clozel M, Fischli W, Clozel JP. Temporal evolution of endothelial dysfunction in a rat model of chronic heart failure. I Am Coll Cardiol 1993;22:615620 .

8. Drexler $H$, Hayoz D, Münzel T, Hornig $B$,

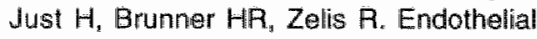
function in chronic congestive heart failure. Am I Cardial 1992;69:1596-1601.

9. Katz SD, Schwarz $M_{n}$ Yuen J, LeJemtel TH. Impaired acetylcholine-mediated vasodilation in patients with congestive heart failure. Role of endothelium-derived vasodilating and vasoconstricting factors. Circulation 1993;88:55-61.

10. Kubro SH, Rector TS, Bank AJ, Williams RE, Heifetz SM. Endothelium-dependent vasodilation is attenuated in patients with heart failure. Circulation 1991;84:15891596.

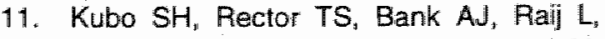
Kraemer MD, Tadros P. Beardslee $M_{\text {s }}$ Garr MD. Lack of contribution of nitric oxide to basal vasomotor tone in heart fallure. Am J Cardiol 1994;74:1133-1136.

12. Winlaw DS, Smythe GA, Keogh $A M_{\text {s }}$ Schyvens CG, Spratt PM, MacDonald PS. Increased nitric oxide production in hearth failure. Lancet 1994;344:373-374.

13. Winlaw DS, Smythe GA, Keogh AM, $_{\text {, }}$ Schryvens CG, Spratt PM, MacDonald PS. Nitric oxide production and heart lailure. Lancet 1995;345:390-391.

14. Teerlink JP, Gray GA, Clozel M, Clozel $J P$. Increased vascular responsiveness to norepinephrine in rats with heart failure is endothelium dependent. Dissociation of basal and stimulated nitric oxide release. Circulation 1994;89:393-401.

15. Nunokawa $Y$, Tanaka $S$ Interferongamma inhibits proliferation of rat vascular smooth muscle cells by nitric oxide generation. Biochem Biophys Res Commun 1992;188:409-415.

16. Guo JP, Milhoan KA, Tuan RS, Lefer AM. Beneficial effect of SPM-5185, a cysteinecontaining nitric oxide donor, in rat carotid artery intimal injury. Circ Res 1994;75;784.

17. Caputo L, Benessiano J, Boulanger $\mathrm{CM}$, Levy BI. Angiotensin II increases cGMP content via endothelial angiotensin II AT1 subtype receptors in the rat carotid artery. Arterioscl Thromb Vasc Biol 1995; 15: 1646-1651.

18. Boulanger CM, Caputo L, Levy BI. Endothelial AT1-mediated release of nitric oxide decreases angiotensin II contractions in rat carotid artery. Hypertension 1995; 26:752-757. 
19. Fishbein $M C$, Maclean $D$, Maroko PR. Experimental myocardial infarction in the rat. Am J Pathol 1978;90:57-70.

20. Takasaki I Chobanian AV. Sarzani $R$, Brecher P. Effect of hypertension on fibronectin expression in the rat aorta. $J$ Biol Chem 1990;265:21935-21939.

21. Ibrahim J, Schachter $M_{n}$ Hughes $A D$, Sever PS. Role of polyamines in hypertension induced by angiotensin II. Cardio vasc Res 1995;29:50-56.

22. Steiner AL, Piagliara AS, Chase LR, Kipnis DM. Radioimmunoassay for cyclio nucleotidles. I Biol Chem 1972;247:11141120.

23. Arnall JF, Warin L, Michel JB. Determinants of aortic cyclic guanosine monophosphate in hypertension induced by chronic inhibition of nitric oxide synthase. $J$ Clin Invest 1992;90:647-652.

24. Arnal JF, Elamrani Al, Micheli JB. Atrial natriuretic factor influences in vivo plasma, lung and aortic wall cGMP concentrations differently. Eur J Pharmacol 1993; 237:265-273

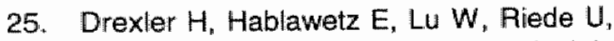
Christes A. Effects of inhibition of nitric oxide formation on regional blood flow in experimental myocardial infarction. CircuJation 1992;86:255-262.

26. Lindsay DC, Jiang $C$, Brunotte $F$, Adamopoulos S, Coats A.J, Rajagopalan B, Poole-Wilson PA, Coillins P. Impairment of endothelium dependent responses in a rat model of chronic heart failure: effects of an exercise training protocol. Cardiovasc Ries 1992;26:694-697.

27. Katz SD, Biasucci L, Sabba C, Strom JA, Jondeau $G$, Galvao M, Solomon S, Nikolic SD, Forman R, Le Jemtel TH. Impaired endothelium-mediated wasodilation in the peripheral vasculature of patients with congestive heart failure. I Am Coll Cardiol 1992; 19:918-925.
28. Imaizumi T, Hirooka $Y$, Takeshita A. Decreased skeletal muscle vasodillation in patients with congestive heart failure. Jpn Circ J 1992;56:500-503.

29. Angus JA, Ferrier CP, Sudhir K, Kaye $D M$, Jennings $G L$. Impaired contraction and relaxation in skin resistance arteries from patients with congestive heart failure. Cardiovasc Res 1993:27:204-210.

30. Hirooka $Y$, Imaizumi T, Harada $S_{\text {" Masaki }}$ $H_{\text {, Momohara }} \mathrm{M}_{\|}$Tagawa $T$, Takeshita $A$. Endothelium-dependent forearm vasodilation to acetylcholine but not to substance $P$ is impaired in patients with heart failure. I Cardiovasc Pharmacol 1992;20 Suppl 12:S221-S225.

31. Stassen FRM, Willemsen MJJMF, Janssen GMJ, Fazzi GE, Schiffers PMH, Smits JIFM, De Mey JGR. Reduced responsiveness of peripheral resistance artery smooth muscle to $a-1$ adrenoreceptor stimulation and calcium at 5 weeks after myocardial infarcion in the rat. 1996; submitted for publication.

32. Stassen FRM, Fazzi GE, Leenders PJA, Smits JFM, De Mey JGR. Coronary arterial hyperreactivity and mesenteric arterial hyporeactivity after myocardial infarction in the rat. 1996; submitted for publication.

33. Scott-Burden $T$, Schini VB, Elizondo $E$ Junquero DC, Vanhoutte PM. Plateletderived growth factor suppresses and fibroblast growth factor enhancesi cytokine-induced production of nitric oxide by cultured smooth muscle cells - Effects on cell proliferation. Circ Res 1992:71: 1088-1100.

34. Pollman MJ, Yamada T, Horiuchi M, Gibbons $\mathrm{GH}$. Vasoactive substances regulate vascular smooth muscle cell apoptosis. Counteracting influences of nitric oxide and angiotensin 11. Circ Res 1996; 79:748-756.

35. Delacretaz E, Hayoz D, Osterheld $M C_{\text {v }}$ Genton $\mathrm{CY}_{\text {, Bunner HR, Waeber B. }}$ Long-term nitric oxide synthase inhibition 
and distensibifity of carotid antery in intact rats. Hypertension 1994;23:967-970.

36. Swentek P, L J, Grove $K$, Deschepper $\mathrm{CF}_{1}$ Schiffrin EL. Vascular structure and expression of andothelin-1 gene in 1NAME-treated spontaneously hypertensive rats. Hypertension 1996;27:49-55.

37. Morton did, Beattie EC, Speirs A, Gulliver F. Persistent hypertension following inhibition of mitric oxide formation in the young Wistar rat: role of renin and wascular hypertrophy. J Hypertens 1993;11: $1083-1088$.

38. Deng LY, Thibault G, Schiffrin EL. Effect of hypertension induced by nitric oxide synthase inhibition on structure and function of resistance arteries in the rat. Clin Exp Hypertens $1993 ; 15: 527-537$.

39. Li JS, Schiffrin EL. Resistance artery structure and neuroeffector mechanisms. in hypertension induced by inhibition of nitric oxide synthase. Am J Hypertens $1994 ; 7: 996-1004$.

40. Dunn WR, Gardiner SM. Na evidence for vascular remodelling during hypertension induced by chronic inhibition of nitric oxide synthase in Brattleboro rats. I Hypertens 1995;13:849-857.

41. Schitfrin EL. Vascular structure in $n-g$ nitro-l-arginine methyl ester-induced thyperlension: methodological considerations for study of small arteries in hypertension. J Hypertens 1995;13:817-821.

42. Archer SL, Huang JMC, Reeve HL, Hampl V, Tolarová S, Michelakis E. Weir EK. Differential distribution of electrophysiologically distinct myocytes in conduit and resistance arteries determines their response to nitric oxide and hypoxia. Circ Res 1996;78:431-442.

43. Frid $M G$, Moiseeva EP, Stenmark KR. Multiple phenotypically distinct smooth muscie cell populations exist in the adult and developing bovine pulmonary arterial media in vivo. Circ Res 1994;75:669-681.
44. Daemen MJAP, De Mey JGR. Regional heterogeneity of arterial structural changes. Hypertension 1995;25:464-473.

45. Neylon CB, Avdonin PV, Dilley RJ, Larsen MA. Tkachuk VA, Bobik A. Different electrical responses to vasoactive agonists in morphologically distinct smooth muscle types. Circ Res 1994;75: 733-741.

46. Nagao T, llliano S, Vanhoutte PM. Heterogenous distibution of endothelium-dependent relaxation resistant to $\mathrm{N}$-g-nitro-larginine in rats. Am J Physiol 1992; 263 : H1090-H1094.

47. Hwa JJ, Ghibaudi L, Williams P, Chatterjee M. Comparison of acethylcholine -dependent relaxation in large and small arteries of rat mesenteric vascular bed. Am J Physiol 1994;266:H952-H958.

48. Wu CC, Chan SJ, Yen MH. Different responses to acethylcholine in the presence of nitric oxide in rat aortae and mesenteric arteries. Clin Exp Pharmacol Physiol 1993;20:405-412. 


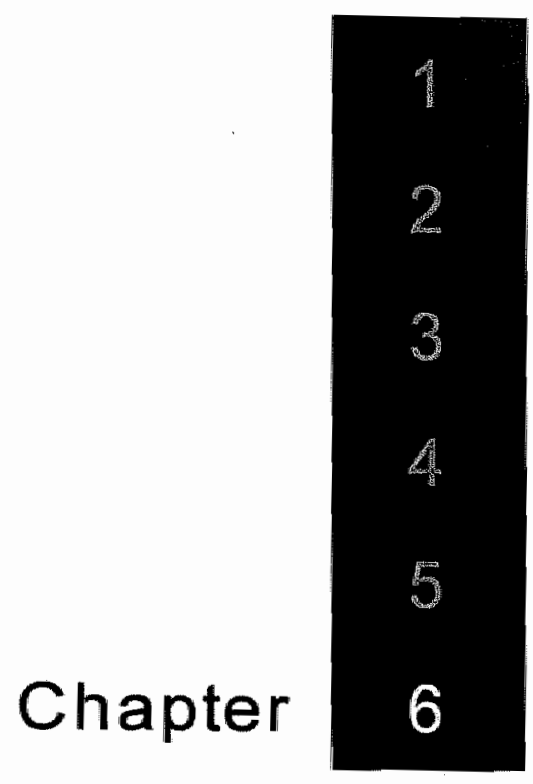

General Discussion 
General

The primary goal of the studies described in this thesis was to investigate the involvement of the peripheral arteries in the pathophysiology of heart failure. Using the myocardial infarcted rat as a model for experimental heart failure, the studies in this thesis show that

(i) myocardial infarction induces alterations in the structure of the peripheral arterial wall.

(ii) the activation of vasodilating/growth-inhibiting systems is an important regulator of the structural alterations of the peripheral arterial wall in experimental heart failure

Background of the studies

The initial research question was based on the recognition of the importance of the close physiological relation between the heart and arteries. The small resistance arteries determine the afterload of the heart and their primary role is to deliver the blood in such a way that each tissue is provided with the correct volume and at the correct pressure (1). In contrast to resistance arteries, it is generally agreed that large conduit arteries impose low resistance to blood flow. However, large arteries are more than passive conduits. The large conduit arteries contribute to cardiac load by conversion of pulsatile flow to virtually continuous tissue perfusion by absorbing the energy of pulsatile flow in the elastic components of their walls and releasing this energy during late systole and diastole (2). Large arteries thus make an important contribution to the mechanical efficiency of the circulation, which may be relevant in a situation of disturbed heart function. The mechanics of both resistance and large conduit arteries may be altered acutely by changes in smooth muscle cell tone and chronically by changes in wall structure (2). As described in chapter 1, an increase in peripheral resistance and a decrease in arterial distensibility and compliance is often seen in patients with heart failure, suggesting changes in both resistance and large conduit artery component of the circulation. The contribution of alterations in wall structure to these peripheral changes were unknown at the start of the experiments.

\section{Structural alterations of peripheral arteries during heart failure} Therefore, the objective of the first study, described in chapter 2, was to determine possible structural alterations in peripheral arteries during heart failure. At specified timepoints after induction of a myocardial infarction (MI) in rats, several large conduit arteries and resistance arteries of the mesenteric and pulmonary vascular beds were excised. The experiments were done in young-adult Wistar rats, which gained weight during the experimental period of 3 months. In sham-operated rats, the increase in body weight was accompanied by a gradual increase in vessel wall mass (medial cross-sectional area), internal and external diameters of the large conduit arteries. Despite similar increases in body weight, this was not observed in MI rats, 
suggesting a relative reduction of vascular growth. The question is whether this is a specific adaptation of the vascular system to cardiac fallure. In general, the distensibility characteristics of arteries depend on the extent to which they are stretched, which in turn depends on transmural pressure (difference between intraluminal and tissue pressure). At low pressures and small diameters, arteries are very distensible, whereas with increasing pressure and diameter they gradually become stiffer (3). Experimental data indicate that $\mathrm{Ml}$ rats have normalized intra luminal (arterial) pressures 3 months after infarction (4) but smaller diameters and no change in collagen and elastin content (chapter 2). This could result in an increase in distensibility. If so, this would indicate that in this model for heart failure, arterial distensibility is not (yet) decreased, in contrast to what is seen in patients with heart failure $(5,6)$. Regardless of its possible function, it is not clear which mechanism is responsible for the observed lack of vascular growth. In chapter 2 , it was hypothesized that it could be the result of the prevailing actions of vasodilators/growth-inhibitors. Subsequent studies showed that 3 months after induction of the infarct, plasma concentrations of the vasodilator/growth-inhibitor atrial natriuretic peptide were still elevated (sham rats: $16.2 \pm 1.0 \mathrm{pg} / \mathrm{ml}$ versus M! rats $36.2 \pm 4.6 \mathrm{pg} / \mathrm{ml}, \mathrm{p}<0.05$ ), while plasma concentrations of the vasoconstrictor/ growth-stimulator angiotensin II were comparable (sham rats: $14.6 \pm 4.4 \mathrm{pg} / \mathrm{ml}$ versus $\mathrm{Ml}$ rats $19.6 \pm 4.4 \mathrm{pg} / \mathrm{ml}, \mathrm{p}=\mathrm{NS}$ ). In order to further investigate this hypothesis, infusion of angiotensin II in MI rats was used to create a model of compensated heart failure with increased plasma concentrations of angiotensin $\|$ in which the effects of angiotensin II on vascular structure and blood pressure could be studied.

\section{Angiotensin II and structural vascular alterations during heart failure}

Surprisingly, while infusion of angiotensin II substantially increased mean arterial blood pressure in sham-operated rats, it did not increase mean arterial blood pressure of $\mathrm{Ml}$ rats above the pressure measured in normotensive control rats. In addition, angiotensin II increased medial cross-sectional area of the large conduit arteries of sham-operated rats, but failed to do so in $\mathrm{Ml}$ rats. Changes in vessel wall mass and diameter can be defined in terms of remodeling, a term introduced by Baumbach and Heisted (7). The term remodeling originally defines structural changes in resistance vessels of hypertensive animals and patients and is associated with a reduction of the lumen and an increase of the media-to-lumen ratio, but is not necessarily associated with net growth. As the term remodeling is now used to describe any change in vascular (or myocardial) structure, Mulvany et al. proposed an adaptation of terminology to allow a precise description of the structural changes that can occur in the vasculature (8). Figure 6.1 shows the manner in which remodeling can change the cross-sections of blood vessels. From the vessel in the centre (shaded), the medial cross-sectional can increase, resulting in hypertrophic remodeling. A lack of change in medial cross-sectional area results 


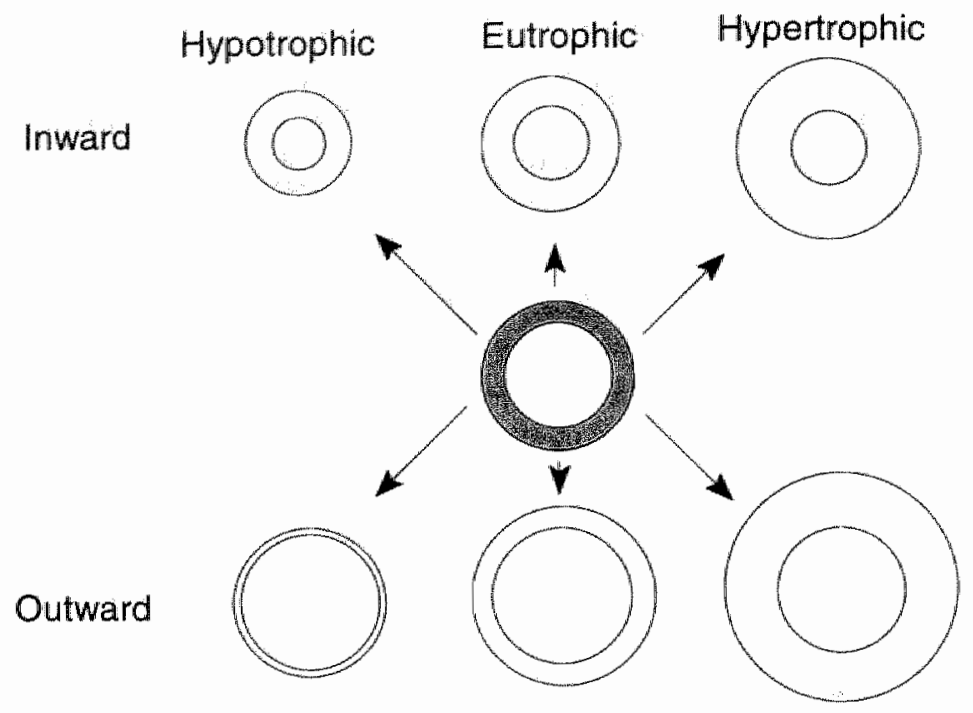

Figure 6.1: Vascular remodeling (Mulvany et al. (B)

in eutrophic remodeling and a decrease in medial cross-sectional area is termed hypothrophic remodeling. These forms of remodeling can be inward with a reduction in lumen (or internal) diameter or outward with an increase in lumen diameter. Thus, in the angiotensin II infused sham rats, the increase in medial cross-sectional area, combined with a slight increase in internal diameter can be defined as hypertrophic outward remodeling. In the Ml rats, however, these vessels showed no remodeling (table 6.1). These paradoxical findings do support the above mentioned hypothesis, that the primary activation of counterregulatory hormonal systems in MI rats is, at least in the compensated phase of heart failure, responsible for suppression of the hypertensive and hypertrophic effects of angiotensin II. In fact, plasma atrial natriuretic peptide and an indicator of NO synthase activity (measured as aortic cGMP concentrations) were proportionally more increased in the angiotensin $\|$ infused MI rats, compared to angiotensin II infused sham rats.

As discussed in chapter 3 , the role of angiotensin II receptors (AT receptors) in this process is not clear. The two types of AT-receptors also have the yin-yang relation of vasoconstrictors/growth-stimulators and vasodilators/growth-inhibitors of vascular growth (9). Thus, the AT1 receptor mediates vasoconstriction and stimulates proliferation of vascular smooth muscle and endothelial cells $(10,11)$ and protects them from apoptosis (12), whereas it has become clear that the AT2 receptor has opposing effects. It lowers blood pressure, mediates apoptosis and possesses anti-proliferative effects (13-16). Stoll et al. hypothesized that angiotensin II can only exert its effects through the AT1 receptor when the AT2 receptor is either absent or inactivated (17). 
Table 6.1: Type of remodeling in the different experimental groups after 14 days of intusions

Group

$$
\text { Chapter Vessel }
$$

Change in Int. Diameter

(\%)
Change in

CSA

(\%)
Type of remodeling according to Mulvany et al. (8)

\begin{tabular}{llllll}
\hline $\begin{array}{l}\text { ANG II infusion } \\
\text { in sham rats }\end{array}$ & 3 & SMA & $+10 \pm 3$ & $+38 \pm 5$ & Hypertrophic outward remodeling \\
$\begin{array}{l}\text { ANG II infusion } \\
\text { in MI rats }\end{array}$ & 3 & SMA & $+8 \pm 5$ & $+3 \pm 6$ & No remodeling \\
$\begin{array}{l}\text { ANG II + AT2 } \\
\text { block in sham rats }\end{array}$ & 4 & SMA & $+13 \pm 6$ & $+3 \pm 9$ & Eutrophic outward remodeling \\
$\begin{array}{l}\text { ANG + AT2 } \\
\text { block in MI rats }\end{array}$ & 4 & SMA & $+15 \pm 5$ & $+5 \pm 7$ & Eutrophic outward remodeling \\
$\begin{array}{l}\text { ANG II + AT2 } \\
\text { block in MI rats }\end{array}$ & 4 & TA & $+1 \pm 7$ & $+0 \pm 4$ & No remodeling \\
$\begin{array}{l}\text { L-NAME inf. } \\
\text { in sham rats }\end{array}$ & 5 & sMA & $-7 \pm 3$ & $+27 \pm 6$ & Hypertrophic inward remodeling \\
$\begin{array}{l}\text { L-NAME inf. } \\
\text { in MI rats }\end{array}$ & 5 & SMA & $-6 \pm 5$ & $+9 \pm 6$ & No remodeling \\
$\begin{array}{l}\text { L-NAME int. } \\
\text { in MI rats }\end{array}$ & 5 & MRA & $-28 \pm 8$ & $-11 \pm 6$ & Eutrophic inward remodeling \\
$\begin{array}{l}\text { ANG II+L-NAME } \\
\text { int. in MI rats }\end{array}$ & 5 & SMA & $+9 \pm 4$ & $+53 \pm 10$ & Hypertrophic outward remodeling
\end{tabular}

Table shows changes in internal diameter and medial cross-sectional area (CSA) of the superior mesenteric artery (SMA), thoracic aorta (TA), and mesenteric resistance arteries (MRA) in the different experimental groups. Inf. = infusion. Data are mean \pm SEM.

In chapter 4 , the role of these AT-receptors was investigated by co-infusing an AT1 antagonist (GR138950) or an AT2 antagonist (PD123319) in angiotensin II infused MI rats. These studies showed that during blockade of the AT1 receptor in MI rats, blood pressure decreased significantly compared to angiotensin II infusion alone. Blockade of the AT2 receptor in angiotensin II infused rats, however, did not further increase blood pressure in sham rats, but did increase the blood pressure in MI rats, which may be explained by an upregulation of the AT2 receptors in the peripheral vasculature of these animals. The structural vascular alterations during the GR138950 infusions can be best defined as hypotrophic inward remodeling, with exception of the carotid artery, which showed a decrease in medial cross-sectional area, but no change in internal diameter. During co-infusion of angiotensin II and an AT1 antagonist, angiotensin II is expected to exert a selective stimulation of the AT2 receptor. Thus, the decrease in medial cross-sectional areas of the large conduit arteries during blockade of the AT1 receptor, indicates that in MI rats the AT2 receptor attenuates vascular structural alterations. The effects of stimulation of the 
AT1 receptor (during blockade of the AT2 receptor) on vascular structure of the large conduit arteries were more heterogenous. As shown in chapter 4 and table 6.1, the effects of PD123319 on the thoracic aorta can be defined as hypertrophic outward remodeling, but only in sham rats as $\mathrm{MI}$ rats showed no remodeling. In contrast, the superior mesenteric artery of both sham and Ml rats showed an eutrophic inward remodeling as the internal diameter increased, without changes in medial crosssectional area. These variations in vascular remodeling during AT2 receptor blockade may be explained by (i) different ratio's of vascular AT1 and AT2 receptors or (ii) the involvement of other regulatory mechanisms.

\section{Vasodilators and vascular structure during heart failure}

Possible counterregulatory neurohormonal systems on the effects of angiotensin II in $\mathrm{Ml}$ rats include the natriuretic peptides and nitric oxide. Both are vasodilators and inhibitors of proliferation of cells in the peripheral vascular wall $(18,19)$. Atrial natriuretic peptide (ANP) was a potential candidate, especially in view of its increased plasma concentration after 3 months of infarction and during angiotensin II infusions (chapter 3). Unfortunately, the one ANP receptor-antagonist described in literature, HS142-1, was not available to us. Studies by others using this compound in animals with heart failure indicate that endogenous ANP contributes to suppression of the activity of the renin angiotensin system and sympathetic nervous system and plays a critical role in maintaining renal hemodynamic function $(20,21)$. ANPs vasodilator actions, however, are attenuated as HS142-1 did not increase mean arterial blood pressure (20).

In chapter 5, L-NAME an inhibitor of NO synthase, was used to study the potential role of nitric oxide in the suppression of hypertensive and structural effects of angiotensin II. Although the basal release of NO was intact in MI rats, co-infusion of L-NAME and angiotensin II did not increase blood pressure in these animals. LNAME infusion in sham rats did induce hypertrophy of the vascular wall of the large conduit arteries. However, in contrast to the hypertrophic outward remodeling seen in angiotensin II infused sham rats, L-NAME decreased the internal diameter slightly, resulting in a type of remodeling, which can be best classified as hypertrophic inward remodeling (table 6.1). Recent data from a study in mice with a disrupted endothelial NO synthase (ecNOS) gene demonstrate a similar phenomenon. These knock-out mice showed a significantly smaller lumen compared to normal mice, suggesting that ecNOS is an important determinant of the caliber of the arterial lumen (22). Interestingly, a reduction in ecNOS gene and protein expression has been shown in the vascular endothelium of animals with heart failure $(23,24)$. This reduction of ecNOS expression in vascular endothelial cells may have been important in the smaller diameters observed in the large conduit arteries of MI rats 3 months after ligation of the coronary artery (chapter 2). Alternatively, in contrast to the decrease in ecNOS of vascular endothelial cells, Comini et al. demonstrated an increase in ecNOS of the vascular smooth muscle cell layer in rats with heart failure. This could have important consequences for peripheral vascular structure. If NO is important 
in the process of vascular remodeling during heart failure, inhibition of NO synthase should have an effect on the peripheral vascular structure in MI rats. As shown in chapter 5, L-NAME alone had no effect on medial cross-sectional areas of the thoracic aorta and superior mesenteric artery of $\mathrm{Ml}$ rats, but did increase medial cross-sectional area of the carotid artery and decreased internal diameter of the $2^{\text {nd }}$ order side branches of the mesenteric resistance arteries (table 6.1). The time of infusion may have been too short to induce changes in all vessels, but the diverse response may also be explained by regional differences of NOS expression in vascular smooth muscle and endothelial cells. The changes in vessel dimensions of L-NAME infused Ml rats indicates that NO may be involved in peripheral vascular alterations during heart failure. The change in peripheral vascular structure during co-infusion of L-NAME and angiotensin II in MI rats supports this hypothesis, and suggest that NO is involved in structural vascular alterations during infusion of angiotensin II in MI rats.

Vascular growth: A balance between cell growth and cell death As mentioned previously, the candidate counterregulatory hormonal systems ANP and NO are potential inhibitors of proliferation of cells in the vascular wall. During the initial experiments with angiotensin $\|$ infusions in sham and $\mathrm{MI}$ rats, BrdU incorporation (5-bromo-2-deoxyuridine as a marker of vascular smooth muscle cell DNA synthesis $(25,26))$ was used to study the effects of angiotensin II on vascular smooth muscle cell proliferation. Preliminary results showed that angiotensin II infusion in sham rats resulted in the expected BrdU incorporation increase in the superior mesenteric artery (26). In angiotensin II infused MI rats however, BrdU incorporation was virtually absent, indicating an inhibition of vascular smooth muscle cell DNA synthesis.

Although a decrease in DNA synthesis could explain the smaller cross-sectional areas in MI rats, a role for programmed cell death (apoptosis) cannot be excluded. It was recently shown that angiotensin $\|$ and NO are antagonists in inducing apoptosis of vascular smooth muscle cells in vitro (12). This mechanism could also be important in the studies described in this thesis, but there are no results (yet) to confirm this.

\section{Heterogenous response of large conduit and resistance arteries} An important aspect of the studies described in this thesis, is the heterogenous response of the different vessels. There were differences among the different large conduit arteries themselves as well as between large conduit and resistance arteries. These differences can be explained, not only on the basis of structural differences, but also by the heterogenous functions of different vascular beds and variations in receptor populations and innervation.

Structural differences among vessels were first recognized by Burton (1944), who showed a variety of sizes, wall thicknesses and proportions of four basic tissues 
(endothelium, elastin, collagen and smooth muscle cells) of different blood vessels (27). The measurement of relative elastin and collagen content of the large arteries in chapter 2, already indicated variations in the proportion of these extracellular matrix components in different large conduit arteries. The carotid artery was shown to contain more elastin compared to the other large conduit arteries investigated. The results in chapter 5 (L-NAME infusions) also demonstrate that the carotid artery exhibited a different pattern of remodeling compared to other large conduit arteries. Since in vitro studies with vascular smooth muscle cells indicate that extracellular matrix components are important in growth-regulation $(28,29)$, it is possible that besides differences in receptor population and innervation, these structural differences participated in the divergent response of the carotid artery.

An unexpected finding in the studies described in this thesis was the lack of structural alterations in the (mesenteric) resistance arteries during the various infusions. First, as shown in chapter 2, the increase in internal diameter and unchanged medial cross-sectional area in MI rats 3 months after surgery can be best defined as eutrophic outward remodeling. Secondly, as shown in chapters 3 and 5 , infusion of both angiotensin II and L-NAME did not increase medial cross-sectional areas of mesenteric resistance arteries despite the increase in blood pressure. In chapters 3 and 5 , possible explanations such as different fixation methods and time of infusion were already discussed. Interestingly, the same paradigm has also been developed in hypertension research. In hypertension, upstream small arteries exhibit growth and remodeling , resulting in a decrease of the luminal area, but it is not yet clear whether this contributes to changes in resistance $(30)$. It is now thought that during hypertension an increase in intrinsic myogenic tone of the smaller arterioles contributes to the increase in peripheral resistance and blood pressure (30). In the present studies, changes in myogenic tone were not investigated, but such changes may have contributed to the increase in peripheral resistance and maintenance of blood pressure.

Finally, arteries, arterioles and veins have been shown to contain different populations of for instance $\alpha$-adrenergic receptor subtypes $(31,32)$ and ANP receptors (33), which could also be involved in different responses of large conduit and resistance arteries.

\section{Conclusions}

The studies presented in this thesis show a complex interaction between activated neurohormonal systems and structural vascular alterations during heart failure. In view of the complexity, it is not easy to deduce the possible implications of these structural and regulatory changes for the patient with heart failure. A complicating factor is that patients frequently display other peripheral vascular alterations, such as atherosclerosis, prior to the development of heart failure. Thus, the vascular alterations induced by heart failure are hard to evaluate. The changes in the rat model, that is smaller medial cross-sectional areas and internal diameters, and its possible beneficial consequences for distensibility and compliance of the large 
conduit arteries may, in patients with heart failure, be overruled by an increase in arterial stiffness due to atherosclerotic plaques. In line with this consideration is a study by Arnold et al., who observed reduced internal diameters in the brachial artery in patients with New York Heart Association Class III and IV heart failure. The expected increase in distensibility, however, was not seen. The authors suggested that the effect of increased stiffness was greater than the effect of decreased diameter, resulting in reduced and not increased arterial compliance (5).

Another important feature is that the rats subjected to myocardial infarction, with or without the various infusions, still have compensated heart failure. Thus, the (primary) activation of counterregulatory hormonal systems in MI rats is well balanced and able to suppress the potential adverse effects of angiotensin II on function and structure of the cardiovascular system. Consequently, these effects of angiotensin II will become evident only when counterregulatory hormonal systems are failing, e.g. in the phase of decompensated heart failure.

Despite these limitations, the present studies show that the interaction between vasoconstrictors and vasodilators is important in peripheral vascular structure during heart failure. Other evidence that neurohormonal factors such as angiotensin II, are potentially important in peripheral vascular alterations comes from studies in patients and animals with heart failure which have been treated with ACE-inhibitors. ACEinhibition has been shown to improve the vasodilatory capacity of forearm conduit and resistance vessels $(34,35)$ and radial compliance in patients with heart failure (36). Also, in rats with myocardial infarction, there were no changes in medial crosssectional area of the mesenteric resistance arteries, 12 months after surgery. Twelve months of ACE-inhibition, however, decreased medial cross-sectional area and collagen density of these resistance arteries and restored endothelial dysfunction $(37,38)$. These beneficial effects of ACE-inhibition on endothelial function were also observed in patients with heart failure (39). These studies indicate that part of the beneficial effects of ACE-inhibition during heart failure may be derived from its favourable effects on peripheral vascular structure, function and regulation.

In conclusion, structural changes in peripheral vessels during experimental heart failure do exist. There is evidence for the same decrease in diameter of large conduit arteries in patients as in the rat model for heart failure (5). The observations in this thesis that (i) structural changes in peripheral arteries develop slowly and that (ii) potential stimulators of the proliferation of cells in the vascular wall do not induce the anticipated changes in vascular structure, lead to the conclusion that these vascular structural alterations are the result of a well balanced, parallel activation of growthinhibiting/vasodilating systems, rather than a specific adaptation of the vascular system to the cardiac dysfunction. 


\section{References}

1. Mulvainy $M u_{\text {s }}$ Aalkjaer C. Structure and function of small anteries. Physiol Rev 1990; $70: 921-961$

2. Ramsey $M W_{i}$ Jones $\mathrm{CJH}$. Large arteries are more than passive conduits. Br Heart 1994:72:34.

3. Dobrin PB: Vascular mechanics, in Geiger SR (ed): Handbook of physiology. Bethesda, Maryland USA, American Physiological Sociely, 1983, vol 3, pp. 65-102.

4. Schoemaker RG: Experimental heart failure in rats. Hemodynamic studies on pathophysiology and therapy [Thesis, University of Maastricht, the Netherlands]., 1989. 116 p.

5. Arnold JMO, Marchiori GE, Imrie JR, Burton GL, Pflugfelder PW, Kostuk WJ. Large artery function in patients with chronic heart fallure. Studies of brachial artery diameter and themodynamics. Circulation 1991;84: 2418-2425.

6. Lage SG, Kopel L, Monachini MC, Medeiros CJ, Pileggi F, Polak JF, Creager MA. Carotid arterial compliance in patients with congestive heart failure secondary to idiopathic dillated cardiomyopathy. Am J Cardiol 1994:74:691-695.

7. Baumbach GL, Heistad DD. Remodeling of cerebral arterioles in chronic hypertension. Hypertension 1989;13:968-972.

8. Mulvany MJ, Baumbach GL, Aalkjaer C, Heagerty AM, Korsgaard $N$, Schriffin $E L_{\text {, }}$ Heistad DD. Vascular remodeling. Hypertension 1996;28:505-506.

9. Nakajima $M$, Hutchinson $H G$, Fujinaga $M$, Hayashida W, Morishita R, Zhang L, Horiuchi $M$. Pratt RE, Dzau VJ. The angiotensin II type 2 (AT2) receptor antagonizes the growth effects of the AT1 receptor: gain-offunction study using gene transfer. Proc Natl Acad SciU S A 1995:92:10663-10667.
10. Timmermans PBMWM, Wong PC, Chiu AT, Herblin WF, Benfleld P, Carini DJ, Lee RJ, Wrexler RR, Saye JAM, Smith RD. Angiotensin ll receptors and angiotensin II receptor antagonists. Pharm Rev 1993;45:205251.

11. Dudley DT, Panek RL, Major TC, Lu GH, Bruns RS, Klinkefus BA, Hodges JC, Weishaar RE. Subclasses of angiotensin II binding sites and their functional significance. Mol Pharm 1990;38:370-377.

12. Pollman MJ "Yamada $T$, Horiuchi M, Gibbons $\mathrm{GH}$. Vasoactive substances regulate vascular smooth muscle cell apoptosis. Counteracting influences of nitric oxide and angiotensin II. Circ Res 1996;79:748-756.

13. Ichiki T, Labosky PA, Shiota $C$, Okuyama S, Imagawa I, Fogo A, Nilmura F, Ichikawa I. Hogan BLM, linagami T. Effects on blood pressure and exploratory behaviour of mice lacking angiotensin II type 2 receptor. $\mathrm{Na}$ ture 1995;377"748-750.

14. Tsuzuki S, Matoba T, Eguchi S, Inagami T. Angiotensin II Type 2 receptor inhibits cell proliferation and activates tyrosine phosphatase. Hypertension 1996;28:916-918.

15. Stoll $M$, Steckelings $M$, Paul $M$, Bottari SP Metzger $A_{\text {, }}$ Unger $T$. The angiotensin AT2receptor mediates inhibition of cell prollieration in coronary endothelial cells. J Clin $\mathrm{km}$ vest $1995 ; 95: 651-657$.

16. Yamada T, Horiuchi M, Dzau VJ. Angiotensin ll type 2 receptor mediates programmed cell death. Proc Natl Acad Sci U S A 1996; 93:156-160.

17. Stoll $M$, Melfert $S_{n}$ Stroth $U$, Unger $T$. Growth or antigrowth: angiotensin and the endothelium. J Hypertens 1995;13:1529. 1534.

18. Itoh $H$, Pratt RE, Dzau VJ. Atrial Natriuretic Polypeptide inhibits hypertrophy of vascular smooth muscle cells. I Clin invest 1990; 86:1690-1697. 
19. Nunokawa $Y$, Tanaka S. Interferon-gamma inhibits proliferation of rat vascular smooth muscle cells by nitric oxide generation. Biochem Biophys Res Commun 1992; 188:409-415.

20. Wada A, Tsutamoto T, Matsuda $Y$, Kinoshita $M$. Cardiorenal and neurohormonal effects of endogenous atrial natriuretic peptide in dogs with severe congestive heart failure using a specific antagonist for guanylate cyclase-coupled receptors. Circulation $1994 ; 89: 2232-2240$.

21. Zhang PL, Mackenzie HS, Totsune $K_{*}$ Troy $\mathrm{JL}$, Brenner BM. Renal effects of high-dose natriuretic peptide receptor blockade in rats with congestive heart failure. Circ Res 1995;77:1240-1245.

22. Moroi $M_{1}$ Gold HK, Yasuda T, Fishman MC, Huang PL. Mice mutant in endothelial nitric oxide synthase: vessel growth and response to injury. Circulation 1996;94:1-154.

23. Smith $C$, Sun $D_{n}$ Hoegler $C_{0}$ Roth $B S_{\text {a }}$ Zhang $X$, Zhao G, Xu X, Kobari $Y$, Pritchard $K$, Sessa WS, Hintze TH. Reduced gene expression of vascular endothelial NO synthase and cyclooxygenase- 1 in heart failure. Circ Res 1996;78:58-64.

24. Comini L, Bachetti T, Gaia G, Pasini E, Agnoletti L, Pepi $\mathrm{P}$, Ceconi $\mathrm{C}$, Curello $\mathrm{S}$, Ferrari R. Aorta and skeletal muscle NO synthase expression in experimental heart failure. I Mol Cell Cardial 1996:28:22412248.

25. Daemen MJ, Lombardi DM, Bosman FT. Schwartz SM. Angiotensin il induces smooth muscle cell proliferation in the normal and injured rat arterial wall. Circ Res 1991;68:450-456.

26. van Kleef EM, Smits JFM, de Mey JFM, Cleutjens JPM, Lombardi DM, Schwartz SM, Daemen MJAP. al-Adrenoreceptor blockade reduces the angiotensin II-induced vascular smooth muscle cell DNA synthesis in the rat thoracic aorta and carotid artery. Circ Res 1992;70:1122-1127.
27. Burton $\mathrm{AC}$ : Walls of blood vessels and their function, in Physiology and biophysics of the circulation, and ed. Chicago, Year Bool Medical Publishers, 1972, pp. 63-75.

28. Yamamoto $M_{x}$ Yamamoto $K_{*}$ Noumura $T$. Type-t collagen promotes modulation of cultured rabbit arterial smooth muscle cells from a contractile to a synthetic phenotype. Exp Cell Res 1993;204:121-129.

29. Thie $M$, Harrach $B_{n}$ Schonherr $E$, Kresse $H$, Robenek H, Rauterberg J. Responsiveness of aortic smooth muscle ceils to soluble growth mediators is influenced by cell-matrix contact. Arteriosel Thromb Vasc Biol $1993 ; 13: 994-1004$.

30. lzzard AS, Heagerty AM. Hypertension and the vasculature: arterioles and the myogenic response. $J$ Hypertens $1995 ; 13: 1-4$.

31. Leech CJ, Faber JE. Different alpha adrenoceptor subtypes mediate constriction of arterioles and venules. Am I Physio! 1996:270:H710-H722.

32. Chen L, Xin X, Eckhart AD, Yang N, Faber JE. Regulation of vascular smooth muscle growth by alpha-1 adrenoreceptor subtypes in vitro and in vivo. J Biol Chem 1995; 270 : 30980-30988.

33. Yoshimoto $T$, Naruse $M$, Naruse $K$, Shionoya $K$, Tanabe $A$. Tanaka $M$, Hagiwara $H_{\text {, }}$ Hirose $S$, Muraki $T$, Demura $H$. Differentitial gene expression of vascular natriuretic peptide receptor subtype in artery and vein. Biochem Biophys Res Commun 1995; 216: 535-539.

34. Jeserich $M$, Pape $L$, Just $H_{1}$ Hornig $B$, Kupfer M, Munzel T, Lohmann A, Olschewski $M$. Drexler $H$. Effect of lang-term angiotensin-converting enzyme inhibition on vascular function in patients with chronic congestive heart failure. Am J Cardiol 1995; 76:1079-1082.

35. Thuillez $C$, Richand $C$, Ficher $C$, Loueslati $H$, Perret L, Auzepy P, Giudicelli JF. Peripheral haemodynamic effects of perindopril compared in patients with congestive heart 


\section{Chapter 6}

fallure and in nomall volunteers. I Hypertens 1988;6:541-S43.

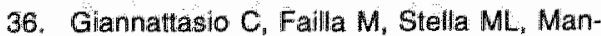
goni $A A_{\text {, }}$ Turrini $D$, Carugo $S$, Pozzi $M$, Grassi G, Mancia G. Angiotensin-converting enzyme inhibition and radial artery compliance in patients with congestive heart failure. Hypertension $1995 ; 26: 491$ 496.

37. Mulder $\mathbf{P}$, Devaux $B$, el-Fertak $L$, Compag non $P$. Fichard $V$, Heny JP, Scalbert $E$. Desche P, Mace B, Thuillez C. Vascular and myocardial protective effects of converting enzyme inhibition in experimental heart lailure. Am I Cardiol 1995;76:28E. $33 \mathrm{E}$.

38. Mulder P, Elfertak L, Richard V, Compagnon $P$, Devaux $B_{i}$ Henry JP, Scalbert $E_{\text {, }}$ Desche $P$, Mace $B$, Thuillez C. Peripheral arter structure and endothelial function in heart fallure: effect of ACE inthibition. Am d Physiol 1996:40: $\mathrm{H} 469-\mathrm{H} 477$.

39. Drexler $H$, Kurz S, Jeserich M, Munzel T, Hornig B. Effect of chronic angiotensinconverting enzyme inhibition on endothelial function in patients with chronic heart failure. Am J Cardiol 1995;76:13E-18E. 


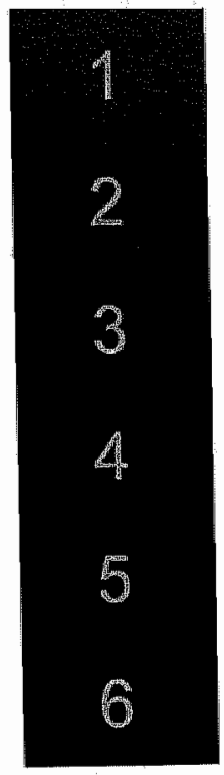

Summary

Samenvatting

Curriculum Vitae

Dankwoord 


\section{Summary}

Heart failure is not a disease but a syndrome, in which the heart is unable to pump sufficient blood to meet the metabolic demands of the peripheral tissues. The initial event can be ischemic heart disease, chronic hypertension or valvular dysfunction. The deterioration of cardiac function is compensated by cardiac hypertrophy and ventricular dilatation. However, the syndrome of heart failure involves more than the heart itself. When the perfusion pressure to peripheral organs drops, a number of neurohumoral systems will be activated, resulting in peripheral vasoconstriction and water retention. Also, the heart is an integral part of the systemic circulation and peripheral vascular tone and resistance are important determinants of afterload and cardiac function. An important aspect of the neurohumoral systems is their dual role in peripheral vascular function and structure. The effectors of the sympathetic nervous system and the reninangiotensin system, norepinephrine and angiotensin $1 \mathrm{I}$, mediate vasoconstriction, but also stimulate vascular smooth muscle cell growth. Vasodilating systems, such as the natriuretic peptides and endothelial-derived nitric oxide (NO), on the other hand, are inhibitors of vascular smooth muscle cell growth. The increase in plasma concentrations of norepinephrine, angiotensin II, atrial natriuretic peptide and the increase in local activity of NO as seen in heart failure may therefore not only alter the hemodynamics, but also the peripheral vascular structure. The aim of this thesis was to investigate whether structural alterations in peripheral arteries develop during experimental heart failure and to determine the role of neurohumoral activation in the regulation of peripheral vascular structure.

To address these questions, an animal model (rat) was used, in which heart failure was induced by ligation of the left coronary artery. Sham-operated rats (no ligation) served as controls. In the first experiment, the development of peripheral structural vascular alterations was studied. One, 3, 5 or 12 weeks after induction of myocardial infarction (MI) or sham operation, several large and small arteries were excised and medial cross-sectional area and media-to-lumen ratios of vessel rings were measured. During the experimental period, body weight gain was equal in both sham and MI rats. In the sham rats, this was accompanied by a parallel increase in the medial cross-sectional area of several large conduit arteries. This increase in medial cross-sectional area was not observed in the MI rats, which may be explained by a decrease in peripheral bloodflow. However additional experiments, in which the blood flow to several peripheral organs was measured 5 and 12 weeks after the operation, showed no major differences between sham and infarct rats. Determination of plasma concentrations of atrial natriuretic peptide and angiotensin II showed increased concentrations of plasma atrial natriuretic peptide and no differences for plasma angiotensin $\|$ in the $\mathrm{Ml}$ rats, 12 weeks after the operation. Thus, the persisted increase in the plasma concentrations of a potential inhibitor of vascular smooth muscle cell growth could 
explain the lack of increase in medial cross-sectional area of the large conduit arteries in MI rats.

The renin-angiotensin system is involved in the regulation of cardiovascular function and volume homeostasis through peripheral vasoconstriction and by water retention in the kidney, respectively. Given this important role in maintaining circulatory homeostasis, it is not surprising that the renin-angiotensin system is activated during heart failure. Plasma angiotensin II concentrations are increased in the acute phase after MI, normalize in the compensated phase and increase again in overt heart failure. However, angiotensin II may have adverse effects on cardiovascular function and/or function in the phase of overt heart failure. Indeed, a significant positive correlation between mortality and plasma concentrations of angiotensin II have been reported in patients with heart failure. To test the hypothesis that increased plasma concentrations of angiotensin II have adverse effects in conditions of an already reduced cardiac output, angiotensin II was infused in sham and MI rats for 14 days (chapter 3 ). A control infusion of saline was given to separate groups of sham and MI rats for 14 days. To determine the effects of angiotensin II on cardiac function, several hemodynamic parameters (cardiac output, stroke volume, total peripheral resistance, mean arterial blood pressure) were measured in conscious rats. The results show that cardiac function was significantly reduced in saline infused $M I$ rats. Infusion of angiotensin II significantly decreased cardiac function in sham rats. Thus, as both the induction of a $\mathrm{MI}$ and the infusion of angiotensin II decreased cardiac function, a substantial decrease in cardiac function was expected in the angiotensin 11 infused $M I$ rats. This however, was not found. The infusion of angiotensin II in $\mathrm{MI}$ rats resulted in comparable decreases in cardiac function compared to saline infused MI rats. Also, other expected findings of the exogenous angiotensin II infusion, e.g. an increase in mean arterial blood pressure and hypertrophy of the peripheral vascular wall were observed in the sham rats, bot not in the MI rats. To determine whether an activation of vasodilating and growth-inhibiting systems such as the natriuretic peptides and NO could be involved in this suppression of the hypertensive and hypertrophic effects of angiotensin II, plasma atrial natriuretic peptide and local vascular NO activity (determined by aortic cyclic GMP concentration) were measured. It was found that plasma atrial natriuretic peptide and aortic cyclic GMP concentrations were higher in the angiotensin II infused MI rats, compared to both saline infused Ml rats and angiotensin II infused sham rats. This suggests that the activation of vasodilating and growth-inhibiting systems is involved in the suppression of the hypertensive and hypertrophic effects of angiotensin II in MI rats.

Another possible explanation for the suppression of hypertensive and hypertrophic effects of angiotensin $\|$ in $\mathrm{Ml}$ rats, is a change in angiotensin (AT) receptor expression. The AT subtype 1 (AT1) receptor mediates the vasoconstricting and growth-stimulating effects of angiotensin 11. The AT subtype 2 (AT2) receptor antagonizes these effects and mediates vasodilation and growth- 
inhibition. Thus, a relative upregulation of the AT2 receptor in the angiotensin II infused MI rats, could explain the suppression of hypertensive and hypertrophic effects of angiotensin 11 in $\mathrm{Ml}$ rats. To examine this hypothesis, angiotensin $\|$ infused sham and MI rats were treated with an AT2 receptor antagonist (chapter 4). Mean arterial blood pressure and medial cross-sectional areas were measured after 14 days of infusion. Results showed that the infusion of the AT2 antagonist did not further increase the blood pressure of angiotensin II infused sham rats. Also, medial cross-sectional areas of most large conduit arteries did not change in these rats. In the $\mathrm{MI}$ rats, however, the co-infusion of angiotensin II and the AT2 antagonist substantially increased mean arterial blood pressure, although it had no effect on the medial cross-sectional areas of large conduit arteries. From these data, it can be concluded that the AT2 receptor is involved in the suppression of blood pressure during the infusion of angiotensin II in $\mathrm{Ml}$ rats, but does not mediate the suppression of its hypertrophic effect on the peripheral vascular wall.

In the last experimental chapter, the possible involvement of NO was investigated (chapter 5). The vascular endothelium is involved in the synthesis of NO, which is important in the regulation of basal vascular tone. This NO synthesis can be suppressed by specific NO synthase inhibitors. One of these inhibitors LNAME, was infused in sham and MI rats for 14 days. In addition, a co-infusion of L-NAME and angiotensin II was given to MI rats. Results showed that L-NAME increased the blood pressure and increased the medial cross-sectional area of several large conduit arteries in sham rats. In the MI rats, L-NAME infusion resulted in a small increase in mean arterial blood pressure, but blood pressure levels were still significantly lower compared to L-NAME infused sham rats. Measurements of peripheral vascular structure demonstrated a significant increase in medial cross-sectional area of the carotid artery but no changes in the other large conduit arteries investigated. The co-infusion of L-NAME and angiotensin II did not result in a further increase of mean arterial blood pressure, but the medial cross-sectional area of the large conduit arteries increased significantly. Thus, the results of chapter 4 and 5 demonstrate that different systems are involved in the suppression of hypertensive and hypertrophic effects of angiotensin II in MI rats. The AT2 receptor seems to be involved in the blood pressure regulation in these rats, while the NO system seems to play a role in the regulation of peripheral vascular structure.

In conclusion, structural alterations in peripheral arteries during experimental heart failure do exist. The observations in this thesis that (i) structural alterations in peripheral arteries develop slowly and that (ii) stimulators of vascular growth do not induce the anticipated remodeling of vascular structure, lead to the conclusion that these vascular structural alterations are the result of a well balanced, parallel activation of growth-inhibiting/vasodilating systems, rather than a specific adlaptation of the vascular system to the cardiac dysfunction. 


\section{Samenvatting}

Hartfalen wordt gekenmerkt door een afgenomen pompfunctie van het hart. Hierdoor schiet de circulatie tekort in het transport van voedingsstoffen naar en afvalstoffen vanuit weefsels en organen. De klachten van de patiënt bestaan uit kortademigheid bij inspanning, en naarmate de pompfunctie verder achteruit gaat, ook in rust. Andere klachten zijn vermoeidheid en vochtretentie. De oorzaken van dit complexe ziektebeeld kunnen zijn; ischemische hartziekte (hartinfarct), langdurige hypertensie, klepafwijkingen of een combinatie van deze 3 factoren. Als de pompfunctie van het hart afneemt, probeert het lichaam het verlies aan orgaanperfusie te compenseren. Het hart zelf compenseert het verlies aan kracht door een toename van de wandmassa (hypertrofie). Daarnaast worden verschillende neurohormonale systemen geactiveerd. Het best bekend zijn de activatie van het sympathisch zenuwstelsel, het renine-angiotensine systeem, de natriuretische peptiden en het stikstof-oxide (NO) 'systeem'.

In dit kader is het belangrijk te beseffen dat hartfalen niet alleen wordt bepaald door afwijkingen van het hart zelf. Een deel van de pompfunctie van het hart wordt bepaald door de eigenschappen van de ermee verbonden vaatboom (perifere slagaders=arteriën). Zo zal bij een vernauwing van deze perifere arteriên de pompkracht van het hart moeten toenemen om de orgaanperfusie op peill te houden. De effecten van de zojuist genoemde neurohormonale systemen zijn voor een belangrijk deel gericht op de perifere organen en arteriën. De activatie van het sympathisch zenuwstelsel en renine angiotensine systeem leidt onder andere tot perifere vaatvernauwing. Het renine-angiotensine systeem is daarnaast ook betrokken bij het vasthouden van water en zouten in de nieren (vochtretentie). Een natuurlijke tegenhanger voor de effecten van deze systemen zijn de natriuretische peptiden, die zorgen voor vaatverwijding en afscheiding van water door de nieren. NO is eveneens een belangrijke vaatverwijder van perifere arteriën.

Een ander belangrijk aspect van deze neurohormonale systemen is dat ze, naast hun functionele effecten op perifere arteriën, ook een rol speien in groei van de cellen in de vaatwand. De belangrijkste celtypen in de perifere vaatwand zijn gladde spiercellen en de vaatwand-bekledende endotheelcellen. Tijdens een activatie van het renine-angiotensine systeem zal de concentratie van angiotensine II in het bloed stijgen; hetzelfde gellt voor noradrenaline tijdens een activatie van het sympathische zenuwstelsel. Deze hormonen stimuleren de groei van de gladde spiercellen in de vaatwand. Ook hier zijn de natriuretische peptiden en NO natuurlijke tegenhangers; zij remmen de celgroei.

Compensatie-mechanismen op het niveau van de perifere arteriën zouden belangrijk kunnen zijn in het verloop van het klinisch ziektebeeld en de uiteindelijke prognose van hartfalen. Hartfalen wordt gekenmerkt door een verhoging van de perifere weerstand, vermoedelijk veroorzaakt door perifere vaatvernauwing. Echter gezien de potentiële effecten van de neurohormonale 
systemen op vaatgroei, is het niet uitgesloten dat ook structurele veranderingen van de vaatwand een rol spelen in deze functionele veranderingen. Tot nu toe ${ }_{3}$ is echter weinig onderzoek verricht naar mogelijke structurele veranderingen in de perifere arteriên tijdens hartfalen. In dit proefschrift worden experimenten beschreven waarin (1) het optreden van structurele veranderingen in de perifere arteriën tijdens hartfalen en (2) de potentiële rol van de neurohormonale activatie hierin, onderzocht zijh. In de experimenten is een diermodel (rat) gebruikt, waarbij hartfalen geïnduceerd werd door afbinden van de linker kransslagader van het hart. Deze operatie resulteert in een hartinfarct dat ongeveer de helft van de linker hartkamer omspant. In ieder experiment werden eveneens controle dieren geopereerd, die een soortgelijke operatie ondergaan, maar waarbij niet de linker kransslagader werd afgebonden (schijn-geopereerde dieren).

Allereerst is gekeken of in dit model voor experimenteel hartfalen structurele veranderingen in de perifere vaatboom optreden (hoofdstuk 2). Na de operatie waarin de dieren well of geen hartinfarct kregen, werden na 1, 3, 5 en 12 weken, verschillende grote en kleine slagaders bestudeerd. Structurele veranderingen van de perifere vaatwand werden gemeten door, van een dwarsdoorsnede van een vat, het vaatwandoppervlak en de verhouding tussen vaatwand- en lumenoppervlak te meten. Tijdens de experimentele periode, nam het lichaamsgewicht van beide groepen toe. In de controle dieren ging dit gepaard met een toename in vaatwandoppervlak van de grote arteriën. In de infarct dieren, echter, trad deze toename in vaatwandoppervlak van de grote arteriën niet op. Bovendien bleek dat de verhouding tussen vaatwand-en lumenoppervlak van de kleinere arteriën na 12 weken kleiner was dan in de schijn-geopereerde dieren. Zoals al gezegd waren de lichaamsgewichten van schijn-geopereerde en infarct dieren niet verschillend, dus werd gezocht naar andere mogelijke verklaringen voor deze bevindingen. Het wordt algemeen aangenomen dat veranderingen in de bloeddoorstroming van een vat (=doorbloeding) invloed heeft op het vaatwandoppervlak. Verlaging van de doorbloeding zal het vaatwandoppervlak verkleinen. Aangezien de infarct dieren een slechtere pompfunctie van het hart hebben, is een verlaging van de doorbloeding in de perifere arteriën niet uitgesloten. Om dit te onderzoeken is in aparte groepen van schijn-geopereerde en infarct dieren 5 en 12 weken na de operatie de doorbloeding naar verschillemde perifere organen gemeten. Uit de resultaten bleek dat de perifere doorbloeding niet belangrijk verschilde tussen infarct en schijn-geopereerde dieren. Dus ook de doorbloeding lijkt geen factor van belang te zijn in het uitblijven van groei in het vaatwandoppervlak van de grote arteriën in infarct dieren. Een tweede mogelijke verklaring kan berusten op neurohormonale activatie. Het bleek dat 12 weken na operatie de plasma concentratie van één van de natriuretische peptiden (atrium-natriuretisch peptide) verhoogd was in de infarct dieren, de plasma concentratie van angiotensine II verschilde niet tussen infarct en schijn-geopereerde dieren. Aangezien de natriuretische peptiden de groei van gladde spiercellen in de perifere vaatwand remmen, zou de blijvende 
activatie van de natriuretische peptiden een rol kunnen spelen in het achterblijven van vaatgroei van de grote arteriën in infarct dieren.

Het renine-angiotensine systeem speelt een belangrijke rol in de regulatie van perifere weerstand en bloedvolume. In de vroege fase na een hartinfarct draagt angiotensine II bij aan het op peil te houden van de verminderde orgaanperfusie door middel van vaatvernauwing en waterretentie. Als de verschillende compensatiemechanismen in balans zijn en de orgaamperfusie op peil is, zal de activiteit van het renine-angiotensine systeem weer afnemen. In een later stadium is beschreven dat het renine-angiotensine systeem weer geactiveerd wordt en de concentratie van circulerend angiotensine II stijgt. Het is niet bekend of de stijging van circulerend angiotensine II verband houdt met de verslechtering van de pompfunctie van het hart in deze fase. Om dit te onderzoeken werd gedurende 2 weken een continu infuus gegeven van angiotensine II aan infarct en schijngeopereerde dieren (hoofdstuk 3). Naast deze 2 groepen (schijn-geopereerde en infarct dieren met angiotensine II infuus) werd ter controle ook een infuus van fysiologisch zout gegeven in zowel schijn-geopereerde als infarct dieren. Allereerst werden in de 4 groepen verschillende hemodynamische parameters gemeten, zoals hartminuutvolume (volume dat het hart uitpompt per minuut), slagvolume (volume dat het hart uitpompt per slag), perifere weerstand, hartfrequentie en bloeddruk. De resultaten toonden aan dat, zoals verwacht, de pompfunctie na een infarct verminderd is. Ook bleek dat de infusie van angiotensine $\mathrm{II}$ in de schijn-geopereerde dieren een substantiële verlaging van de pompfunctie tot gevolg had. Dus, zowel een infarct als de infusie van angiotensine II verlagen de pompfunctie. Met deze resultaten in het achterhoofd werd verwacht dat de combinatie van angiotensine II infuus en de aanwezigheid van een infarct, de pompfunctie sterk zou verlagen. Dit was niet het geval. Het bleek dat de angiotensine II infuus in infarct dieren zorgde voor een vergelijkbare daling in pompfunctie als in zout geïnfundeerde infarct dieren. Een stijging van de plasma concentratie angiotensine 11 in infarct dieren lijkt dus niet verantwoordelijk voor een verslechtering van de pompfunctie. De infusie van angiotensine II in de schijn-geopereerde dieren had bovendien een substantiële bloeddrukstijging én een toename van het vaatwandoppervlak van de grote arteriën tot gevolg. Echter, angiotensine II infuus in infarct dieren had slechts een lichte bloeddrukstijging tot gevolg en het vaatwandoppervlak veranderde niet. Een mogelijke verklaring hiervoor zou kunnen liggen in de neurohormonale activatie tijdens de angiotensine II infuus. In dit experiment werden naast de plasma concentratie van angiotensine $\mathrm{I}$, ook de plasma concentratie van atrium-natriuretisch peptide en een afgeleide van NO activiteit in de vaatwand gemeten. Uit deze bepalingen bleek dat de plasma angiotensine II concentratie in het plasma niet verschilde in zout geïnfundeerde schijn-geopereerde en infarct dieren en dat het angiotensine II infuus resulteerde in een vergelijkbare stijging van de plasma angiotensine II concentraties in schijn-geopereerde en infarct dieren. De meting aan de verschillende vaatverwijdende systemen toonde aan dat zowel de atrium- 
natriuretisch peptide plasma concentratie als locale activiteit van $N O$ in de vaatwand hoger waren in de angiotensine II geinfundeerde infarct dieren. Deze resultaten suggereren dat de sterkere activatie van natriuretische peptiden en NO (als vaatverwijdende en groei remmende systemen) verantwoordelijk zijn voor het laag houden van bloeddruk en het onveranderde valatwandoppervlak in infarct dieren. Uit de resultaten van hoofstuk 2 en 3 wordt geiconcludeerd dat de activatie van de vaatverwijdende en groei-remmende systemen belangrijk is bij de regulatie van bloeddruk en structurele vaatwandveranderingen in infarct dieren.

Hormonale systemen zoals het renine-angiotensine systeem oefenen hum invloed op perifere arteriën en organen uit via specifieke celgebonden receptoren. Voor angiotensine II zijn dit de angiotensine (AT) receptoren. Uit onderzoek blijkt dat de AT receptoren heterogeen zijn, dat wil zeggen, dat verschillende subtypen bestaan met distincte functies. De belangrijkste en best beschreven AT receptoren zijn tot dusver de AT subtype 1 (AT11) en de AT subtype 2 (AT2) receptoren. Vaatvernauwing en groeistimulatie komen tot stand via de AT1 receptor. Recentelijk is duidelijk geworden dat de AT2 receptor een natuurlijke tegenhanger is van de AT1 receptor. Dus, de AT2 receptor reguleert vaatverwijding en groeiremming van de gladde spiercellen in de vaatwand. De resultaten van hoofdstuk 3 , namelijk dat angiotensine $\| \mathbb{i n f u u s}$ in infarct dieren geen substantiële bloeddrukverhoging geeft en geen effect heeft op het perifere vaatwandoppervlak, zou verklaard kunnen worden door grotere rol van de AT2 receptoren. Om dit te onderzoeken is gebruik gemaakt van specifieke substanties die óf de AT1 of de AT2 receptor remmen (zogenaamde receptor antagonisten). In dit experiment (hoofdstuk 4) werd opnieuw een angiotensine II infuus gegeven aan infarct of schijn-geopereerde dieren, al dan niet gecombineerd met een infusie met een specifieke AT2 antagonist. Opnieuw werden bloeddruk en perifeer vaatwandoppervlak na 2 welken infusie gemeten. Uit de resultaten blijkt dat de AT2 antagonist in angiotensine II geïnfundeerde schijn-geopereerde dieren geen effect heeft op de bloeddruk (deze wordt onveranderd verhoogd) en in de meeste arteriën geen effect heeft op het vaatwandoppervlak. In de infarct dieren echter had de infusie met AT2 antagonist een substantiële bloeddrukstijging tot gevolg, maar veranderingen in het perifere vaatwandoppervlak werden niet gevonden. Uit de resultaten van dit experiment blijkt dat in infarct dieren, de AT2 receptor, als natuurlijke antagonist van de AT1 receptor, wél betrokken is bij het laag houden van de bloeddruk gedurende een infusie van angiotensine II in infarct dieren, maar niet bij de veranderingen in de perifere vaatwandstructuur.

Wat overblijft is de vraag, welke systemen betrokken zijn in de regulatie van perifere vaatwandstructuur. In het laatste experiment is de potentiële rol van NO onderzocht (hoofdstuk 5). Stikstof-oxide of NO wordt onder andere gemaakt door het endotheel dat de vaatwand bekleedt. Dit door het endotheel gesynthetiseerde $\mathrm{NO}$ is een belangrijke vaatverwijder en betrokken bij de bloeddrukregulatie. Daarnaast remt NO de groei van de gladde spiercel in de vaatwand. De synthese van NO kan geremd worden door specifieke substanties die de activiteit van het 
verantwoordelijke NO-synthetiserende enzym verfagen. Een dergelike remmer (L-NAME) werd gedurende 2 weken geinfundeerd in infarct en schijngeopereerde ratten. Bovendien werd gekeken naar het effect van een combinatie van angiotensine II en L-NAME infuus in infarct dieren. De resultaten toonden aan dat de infusie van L-NAME in schijn-geopereerde dieren de bloeddruk verhoogde. Deze verhoging werd verwacht aangezien tijdens de remming van NO synthese een belangrijk vaatverwijdend systeem wegvalt. Hierbij viel op dat de bloeddruk absoluut en relatief minder verhoogd was dan tijdens een angiotensine II infuus in schijn-geopereerde dieren. Een tweede effect van het L-NAME infuus in schijngeopereerde dieren was een verhoging van het vaatwandoppervlak van verschillende perifere grote arteriën. In de infarct dieren zorgde de L-NAME infusie eveneens voor een bloeddrukstijging die ditmaal relatief gezien vergelijkbaar was met de stijging in de L-NAME geïnfundeerde schijngeopereerde dieren. Absoluut was de bloeddruk van L-NAME geïnfundeerde infarct dieren nog steeds lager dan in L-NAME geïnfundeerde schijn-geopereerde dieren. Wat het vaatwandoppervlak van de perifere arteriën betreft, bleek dat bij een van de onderzochte arteriên (de halsslagader=arteria carotis) het vaatwandoppervlak wel vergroot was in L-NAME geïnfundeerde infarct dieren, terwijl in andere grote arteriën geen structurele veranderingen optraden. Alhoewel zowel angiotensine II als L-NAME een lichte verhoging van de bloeddruk tot gevolg had in infarct dieren, had de combinatie van beide geen effect op de bloeddruk (d.w.z. vergelijkbaar met L-NAME geïnfundeerde infarct dieren). Echter, het vaatwandoppervlak van alle bestudeerde perifere arteriën was substantieel verhoogd in de infarct dieren geïnfundeerd met zowel angiotensine II als L-NAME. Uit de resultaten van hoofdstuk 4 en 5 wordt geconcludeerd dat verschillende systemen betrokken zijn bij het laag houden van de bloeddruk en het optreden van structurele vaatwandveranderingen tijdens een angiotensine II infuus in infarct dieren. De AT2 receptor lijkt betrokken te zijn bij het laag houden van de bloeddruk in angiotensine 11 geïnfundeerde infarct dieren. Een vaatverwijdend systeem als NO lijkt betrokken te zijn bij de veranderingen in de perifere vaatwandstructuur. Immers, de infusie van de NO-synthase remmer LNAME bleek het vaatwandoppervlak van de halsslagader al te verhogen, terwijl de combinatie van zowel angiotensine II als L-NAME het vaatwandoppervlak van diverse grote arteriën vergrootte.

Samenvattend, in dit proefschrift wordt aangetoond dat perifere structurele vaatwandveranderingen zich pas in een laat stadium na het optreden van een hartinfarct in de rat ontwikkelen. Bovendien blijkt dat perifere arteriën in infarct dieren relatief ongevoelig zijn voor hormonen met een groei stimulerende werking. Uit de experimenten beschreven in dit proefschrift blijkt dat dit met name het gevolg is van een activatie van groei remmende en vaatverwijdende systemen. 


\section{Curriculum Vitae}

Sylvia Heeneman

2 juli 1968

1980-1986

1986-1991

1992-1996

1997
Geboren te 's-Gravenhage

WWO, C.S.G. Overvoorde te Rijswijk

Studie Gezondheidswetenschappen

afstudeerrichting biologische gezondheidkunde, Universiteit Maastricht, Maastricht

Onderzoeker in opleiding, Academisch Ziekenhuis Maastricht, afdeling Pathologie.

Post-doctoraal medewerker bij dezelfde vakgroep

\section{List of publications}

Heeneman S, Deutz NEP (1993). The effect of 4 days methionine sulfoximine administration on net muscle protein breakdown in rats. Clinical Nutrition 12:182190.

Heeneman S, Deutz NEP (1993). Effects of decreased glutamine supply on gut and liver metabolism in vivo in rats. Clinical Science 85:437-444.

Heeneman S, Deutz NEP, Buurman WA (1993). The concentrations of glutamine and ammonia in commercially available cell culture media. J. Immunological Methods 166:85-91

Heeneman S, Dejong CHC, Deutz NEP (1994). Effects of methionine sulfoximine treatment on renal aminoacid and ammonia metabolism in rats. Pflugers Arch. 427:524-532.

de Blaauw I, Heeneman S, Deutz NEP, von Meyenfeldt MF (1997). Increased whole body protein and glutamine turnover in advanced cancer is not matched by an increased muscle protein and glutamine turnover. J Surg Res. In press

Heeneman S, Leenders PJA, Aarts PLJW, Smits JFM, Arends JW, Daemen MJAP (1995). Peripheral vascular alterations during experimental heart failure. Do they exist? Arterio. Tromb. Vasc. Biol. 15: 1503-1511 
Heeneman S, Smits JFM and Daemen MJAP (1997). Vascular remodeling during heart failure. in: Cardiovascular remodeling and functional interactions. Maruyama M, Hori M and Janicki JS (Eds). Springer Verlag: Tokyo. pg 5-18.

Heeneman S, Smits JFM, Leenders PJA, Schiffers PMH, Daemen MJAP (1997). Effects of angiotensin II infusions on cardiac function and peripheral vascular structure during compensated heart failure. Arterio. Tromb. Vasc. Biol. In press.

Heeneman S, Smits JFM, Leenders PJA, Daemen MJAP(1997). Opposing effects of angiotensin type 1 and 2 receptor blockade on blood pressure and peripheral vascular structure in rats with a myocardial infarction. Submitted for publication.

Heeneman S, Brouwers-Ceiler, DL, Leenders PJA, Smits JFM, Daemen MJAP (1997). Vascular structure and basal release of nitric oxide during experimental heart failure in the rat. Submitted for publication. 


\section{Dankwoord}

Eigenlijk is de lijst van mensen die een stuk(je) werk en moeite terugzien in dit proefschrift eindeloos. En eigenlijk is mijn dank daarvoor iets persoonlijks en ook liever zo uitgesproken. Ik zal tegen een ieder van jullie ook vast wel eens (en bij sommige wel vaker) 'bedankt' hebben gezegd. Onthou die in ieder geval, was echt gemeend, ook als je je naam in de rest van dit stukje niet tegenkomt. Maar aangezien zo"n dankwoord een prettig leesbaar (en voor sommige ook het enige leesbare) stukje is, heb ik me toch maar gewaagd aan enkele schriftelijke bedankjes.

Beste Mat, volgens mij had je af en toe het idee dat ik soms erg m'n eigen gang ging, maar als reefknuttel krijg je te weinig eer. Je stond uiteindelijk toch aan het roer en ik heb veel van je geleerd.

Jan-Willem en Jos, op de achtergrond steeds aanwezig, bedankt voor de nuttige en wetenschappelijke back-up.

De commissie, Prof. Dr. H.J.J. Weilens, Prof. Dr. C.A.M.A.V. Bruggeman, Prof. P.W. de Leeuw en Prof. R.S. Reneman, dank voor het beoordelen van het manuscript and Dr. C. Aalkjaer, thank you for reading my thesis.

Beste Peter, in dit dankwoord heb je je de ruimte tussen duim en wijsvinger toegeëigend, voor het gemak reken ik met de vingertjes van Gebbe en Klaas. Talloze operaties en metingen in dit proefschrift zijn voor jouw rekening en allemaal waren ze, zoals je dat zelf altijd fijntjes opmerkte; fántástísch. Ik denk ook met veel plezier terug aan patronen, hartige taart eten met Door, oppassen, spelen met Klaas en Gebbe en de andere 'schatjes'. Het zal dus wel lukken als buren, maar de boom blijft staan.

Verder de andere paranimf op deze promotie, Annemieke. Samen in 1986 op 2hoog achter begonnen in Maastricht. We wonen nu wel wat meer in een NoordZuid verhouding, maar het contact blijft, gelukkig maar.

Dit rijtje is niet compleet zonder m'n 'derde' paranimf, Jakob. Eten, film en jus bij Take 5 blijven een perfecte combinatie.

Het cardiovasculair lab, met als basis Anique, Monique, Petra en later ook Patrick en Edwin, dank voor veel coupes, metingen en andere klusjes. Kamer 5.10 en (ex-)inzittenden, Ellen, Robert, Richard en Esther, d'r valt af en toe niet te werken (kan altijd thuis nog), maar gezellig is het wel. Magda, dank voor allerlei tips en net als Robert-Jan, voor het doorworstelen van het proefschrift concept. En verder niet te vergeten: Aggi, Jack en Cor.

Ook veel op en neer gelopen tussen pathologie en farmacologie, aldaar ook hulp gevraagd en gekregen van Jacques, Elsbeth, Carolien, Debby, Francy, Paul, Marjorie, Lillian, Ger en Matthijs. 
Het zou niet af zijn, of liever, het was niet eens begonnen, als ik op deze plaats niet even terugdenk aan m'n B.M.C. stageplaats bij de vakgroep Algemene Heelkunde onder leiding van Wim Buurman en Mick Deutz. Een hele leerzame tijd, met dank aan alle (oud)-medewerkers.

Soms blijft dank voor hulp en steun onuitgesproken omdat deze zo vanzelfsprekend is. Veel belangstelling en steun van familie en vrienden valt voor mij in die categorie. Lieve $\mathrm{Ma}$, als mensen nu nog eens vragen 'wat Syl nu eigenlijk doet daar in Maastricht' en 'wanneer studeert ze nu eens af', stop je ze maar dit boekje in hun handen, dan houden ze wel weer even hun mond. Lieve Peet, toch jammer dat Maastricht geen groter vliegveld heeft. Verder ben ik blij met ieder van jullie die dit feest met mij kan vieren en denk aan m'n vader die er bij had moeten zijn. Jons, vanzelfsprekend, er zijn well leukere dingen dan allebei promoveren, maar AlO-cursussen kunnen tot leuke dingen leiden en die ligt nu lekker te slapen. 